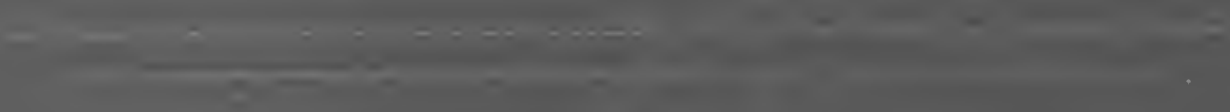

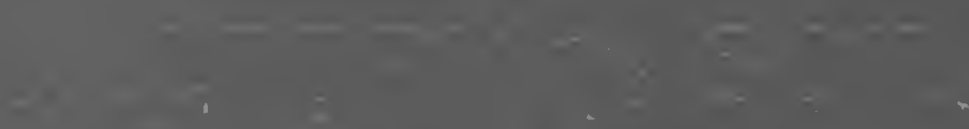

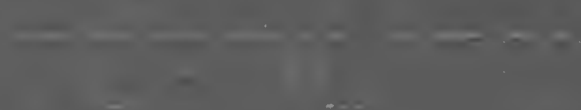

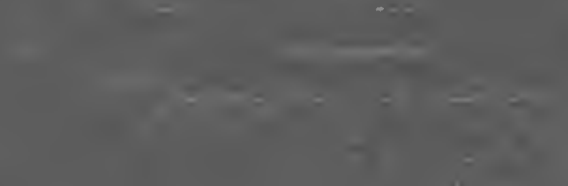

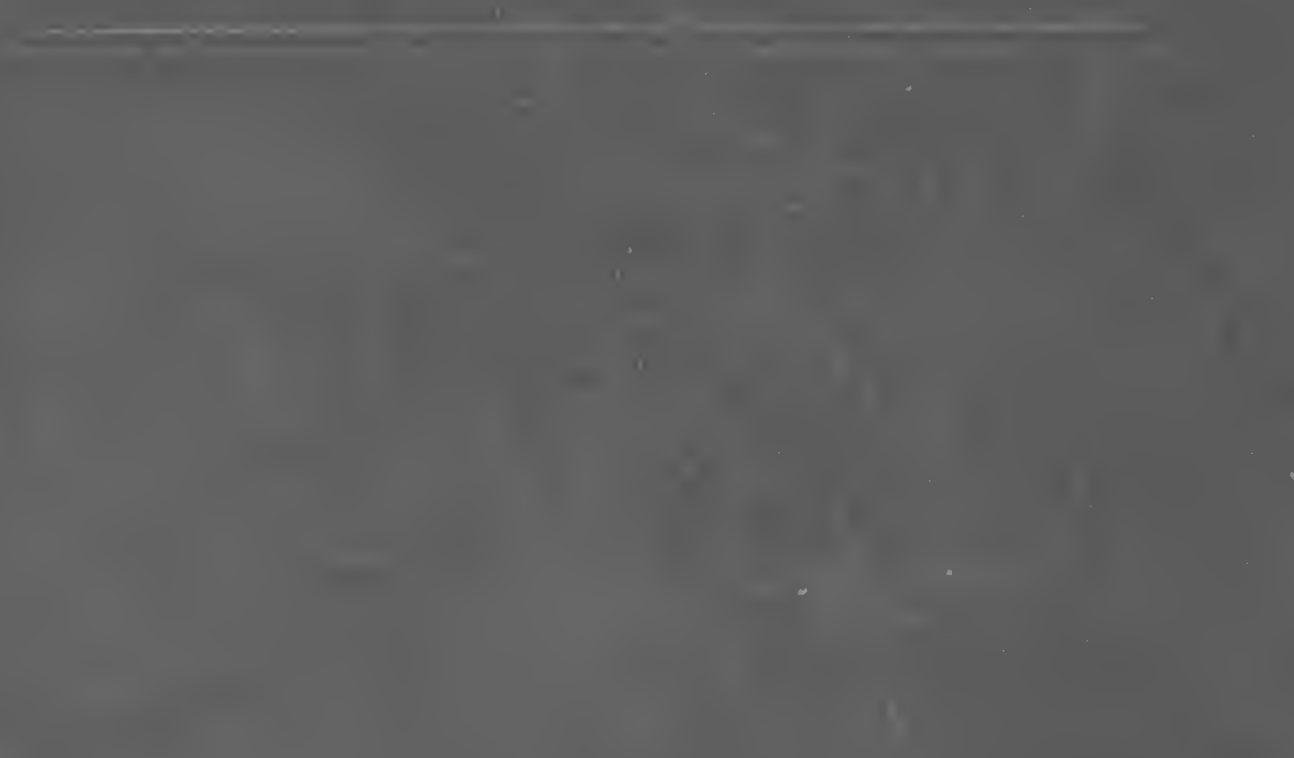

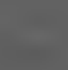

*

, 


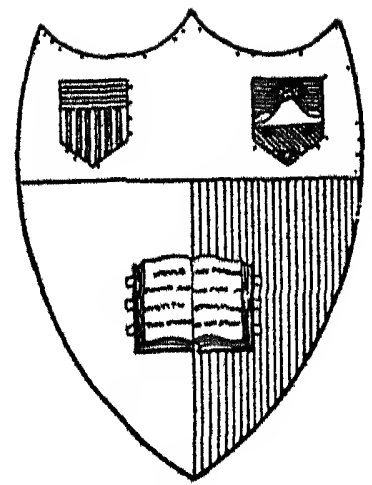

Niw

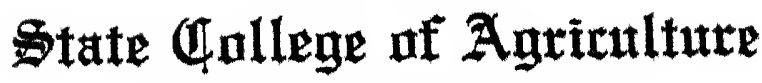

At (T)

Jthara, 封.

Tithrary 


\section{Date Due}

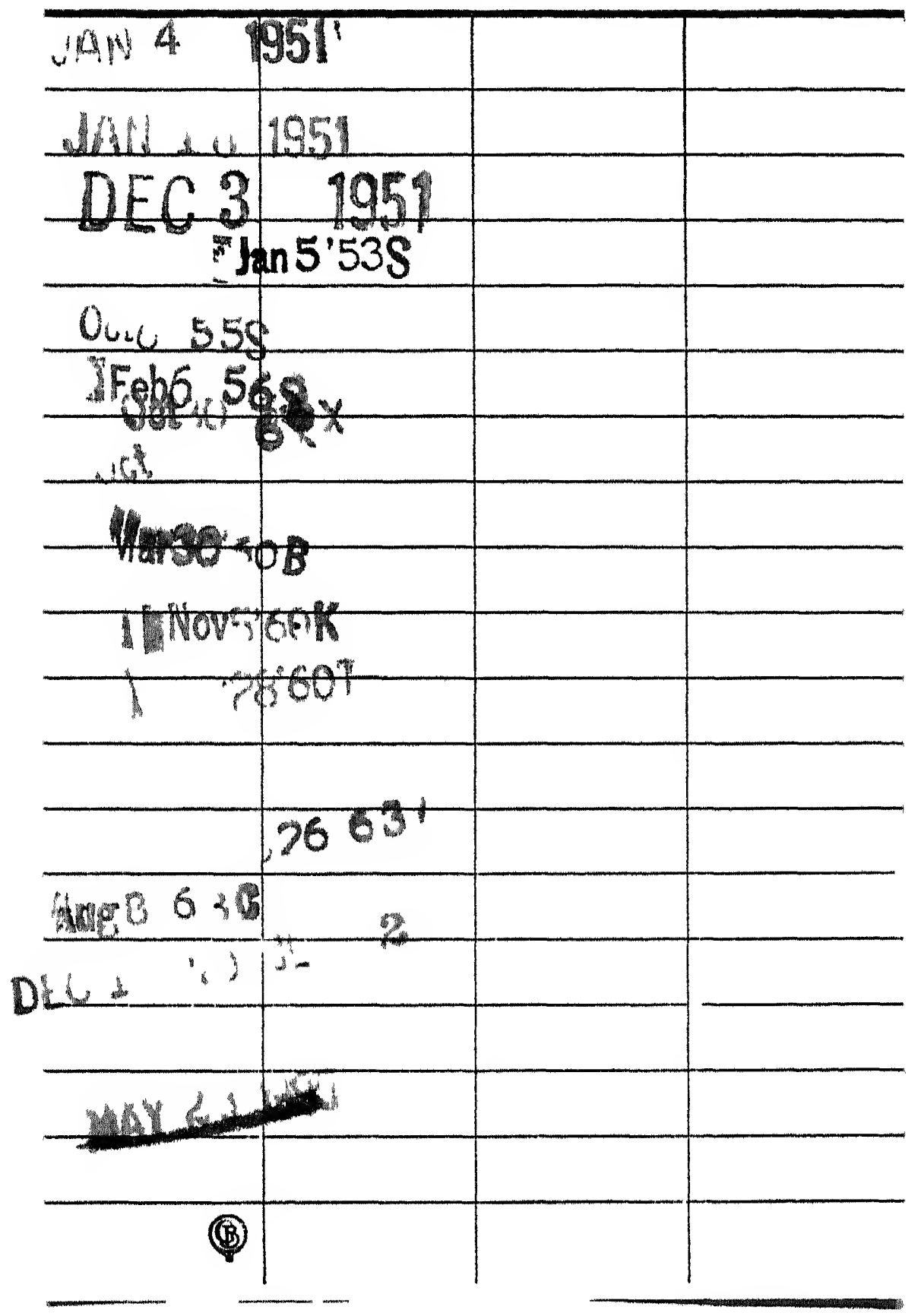

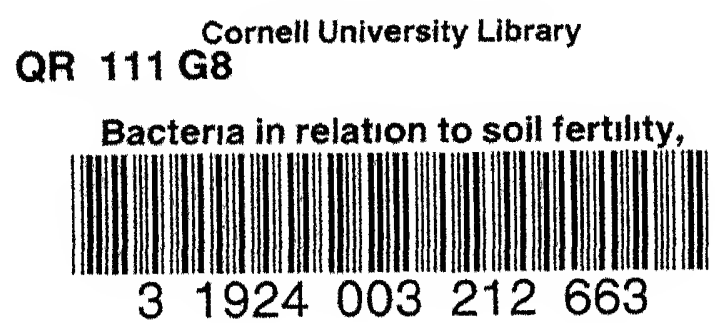




\section{BACTERIA IN RELATION TO SOIL FERTILITY}




\title{
BACTERIA IN RELATION TO SOIL FERTILITY
}

BY

\author{
JOSEPH E. GREAVES, M.S., Ph.D. \\ Professor of Bacteriology and Physiological Chemistry, \\ Utah Agricultural College \\ Author of "Agricultural Bacteriology" \\ AND
}

ETHELYN O. GREAVES, M.S.

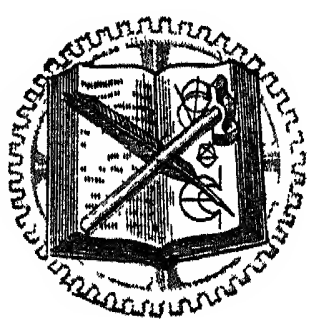

NEW York

D. VAN NOSTRAND COMPANY

Eight Warren Street

I 925 


\section{COPYRIGHT I 925, BY \\ D. VAN NOSTRAND COMPANY}

All rights reserved, including that of translation into the Scandinavian and other foreign languages

Printed in the United States of America 
Dedicated To Our Mothers

$$
\begin{gathered}
M A R Y \text { and } M A E \\
\text { as a token of love } \\
\text { and affection }
\end{gathered}
$$




\section{PREFACE}

$\mathrm{HE}$ voluminous literature dealing with injurious bacteria
contrasted with the meager volume devoted to a consideration of the beneficial class leads many to conclude that most bacteria are injurious. This is a wrong conclusion, as most microörganisms are beneficial. Moreover, most of the writing on this latter class is technical and accessible only to the college man. Only a small fraction of the individuals of the United States ever reach the college. Yet the workings of the beneficial bacteria are of importance to all. The soil bacteria are of special economic importance to all tillers of the soil because the productivity of the soil is intimately associated with therr activity. True, they toil for the unskilled as well as for the skilled tiller of the soilbut the one trusts to chance, the other to reason. The different results obtained by the two classes of workers are reflected in the harvest.

This little book is an effort to present in non-technical language the fascinating story of the class of microörganisms which inhabit the soil. It is hoped that it will prove valuable not only to the high-school student but also to the general reader, and especially to the agriculturist. If to these it furnishes a faint glimpsc into this wonderful realm and creates interest for knowledge in this vital subject, the authors will feel that their labors have not been in vain.

It is with the greatest of pleasure that we express our thanks to Professor William Peterson for offering valuable suggestions as well as to Mrs. Blanche C. Pittman for her painstaking care in the preparation of the manuscript for the press.

J. E. G.

E. O. G.

Logan, Utah, April, I925. 



\section{CONTENTS}

\section{CHAPTER I \\ Development of Soil Bacteriology}

Discovery of Bacteria

PAGES

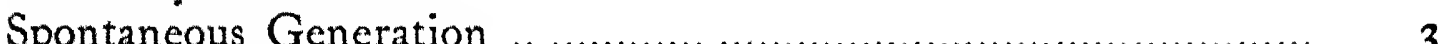

Soil Bacteriology

CHAPTER II

Bacteria and Their Role in Nature

What are Bacteria?

I 2

Where do Bacteria Occur? ............................................. I 4

What are the Functions of Bacteria? ............................. $\quad$ I 7

CHAPTER III

Shape and Structure of Microörganisms

Shape of Bacteria

$V$ ariation in Form ...................................................... 24

Reproduction ................................................... 25

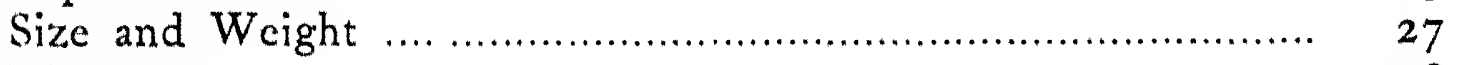

Movement f.............................................................. 28

Cell Structure ......................................................... 30

Spore Formation ... ... .............................................. 32

Longevity of Bacteria ............................................ 33

Morphology of Yeast ........................................... 33

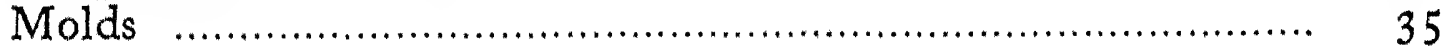

CHAPTER IV

Classification of Bacteria

Method of Classification ......................................... 36

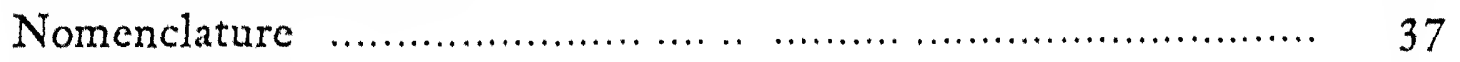

Difficulties with Bacteria ......................................... 37

Migula's Classification of Bacteria.................................. 38

Classification of Socicty of Amcrican Bacteriologists .............. 39 


\section{The Chemistry of Bacteria}

How Bacteria are Studied ......................................... 42

Water ................................................................... 44

Solids ...................................................................... 45

Variation in Composition of Different Parts of the Cell......... 46

Toxins ..................................................................... 47

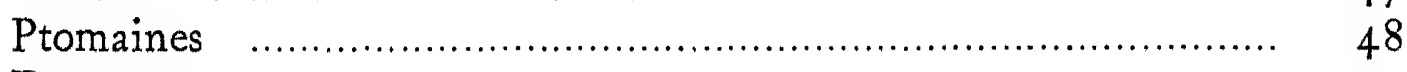

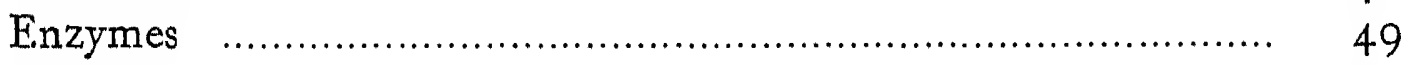

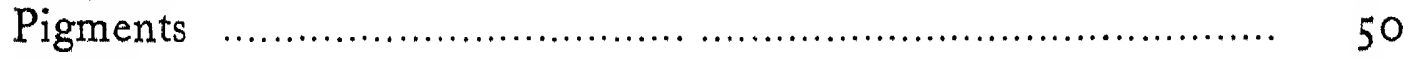

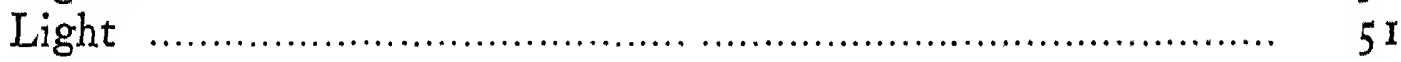

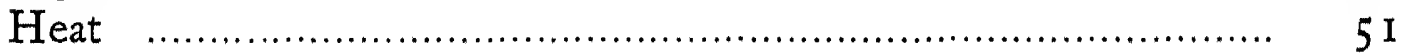

\section{CHAPTER VI \\ Food Requirements of Bacteria}

How Bacteria Feed ...................................................... 53

Why Bacteria Need Food ........................................... 54

Quantity of Food Required ........................................... 54

Kind of Food Required........................................... 55

Water .................................................................. 56

Carbon Requirements ............................................. 57

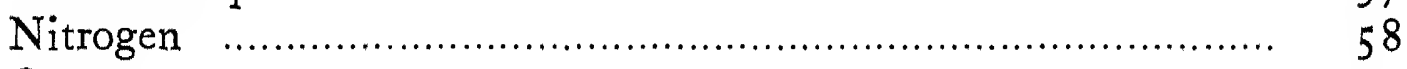

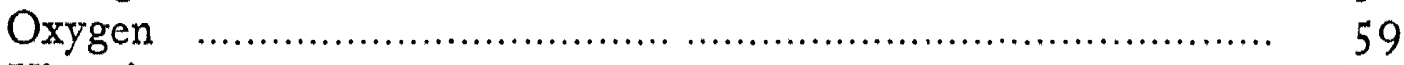

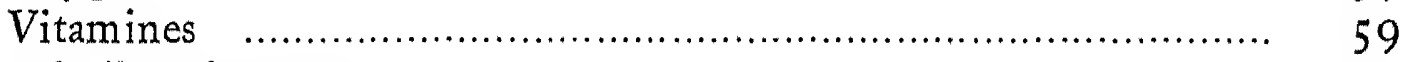

Ash Requirements ................................................ 59

Mutual Relationship Between Plants................................ 60

CHAPTER VII

Factors Infuencing Bacterial Growth

Temperature ............................................................. 62

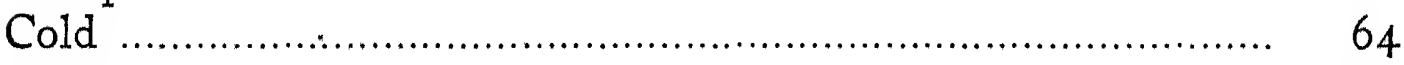

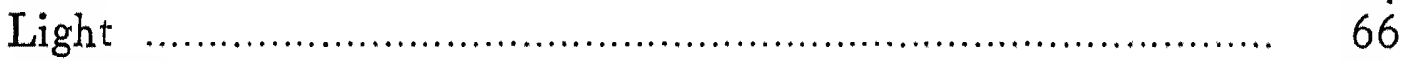

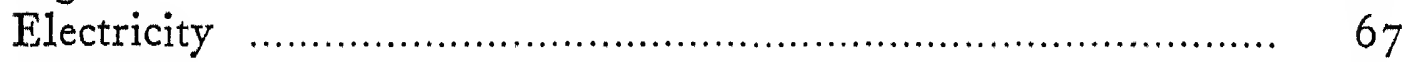

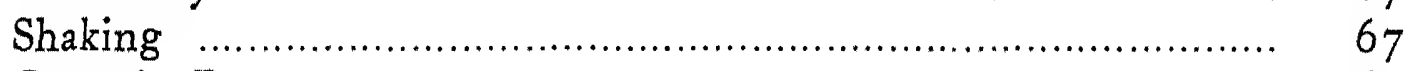

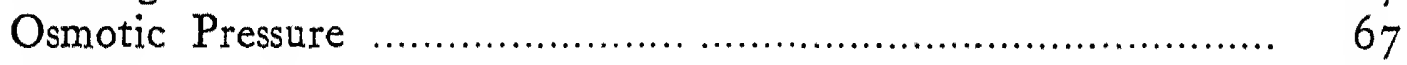

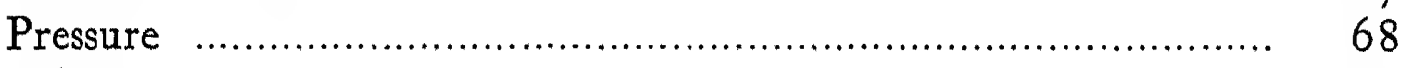

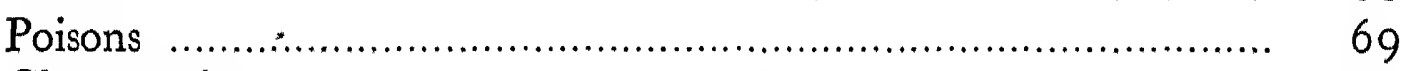

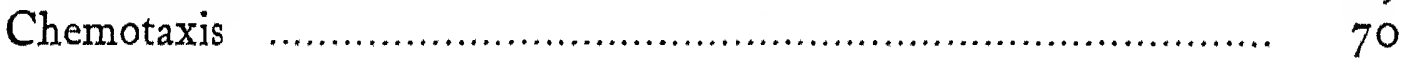


Physical Agencies …................................................... 72

Temperature Changes _.................................................... 72

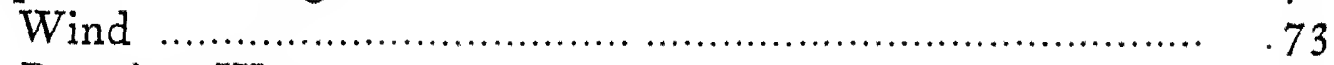

Running Water .................................................... 74

Action of Waves .................................................... 75

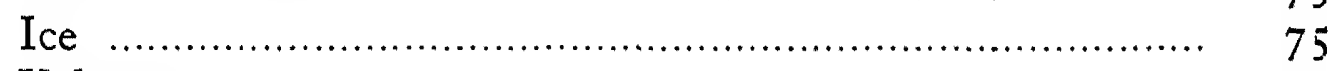

Volcanoes ….......................................................... 75

Chemical Agencies ......................................................... 76

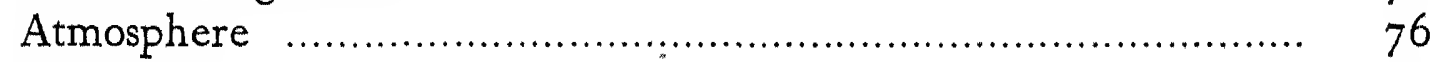

Water ….............................................................. 77

Biological Agencies ........................................................ 78

Bacteria as Soil Formers ............................................. 78

Calcium Carbonate ................................................ 80

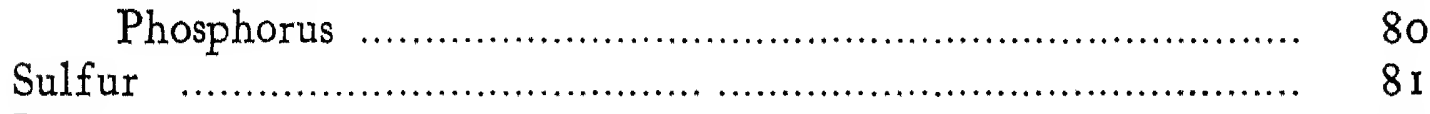

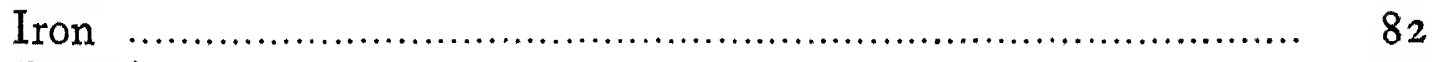

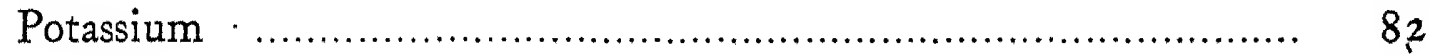

\section{CHAPTER IX}

\section{Soil Texture, Structure, and Composition}

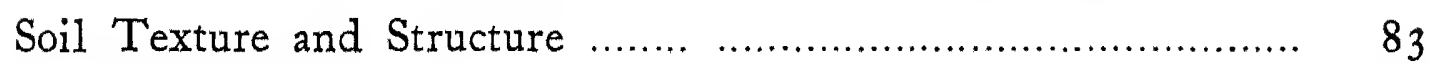

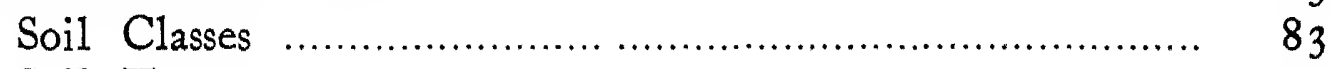

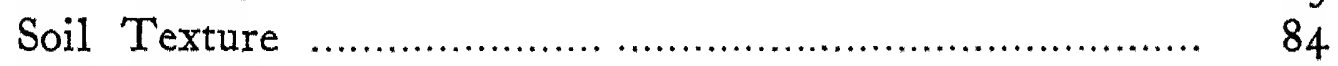

Soil Structure ........................................................ 85

Plant Requirements and Soil Composition ………................. 86

Plant Requirements .................................................... 87

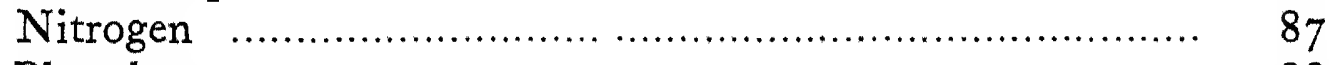

Phosphorus …........................................................ 88

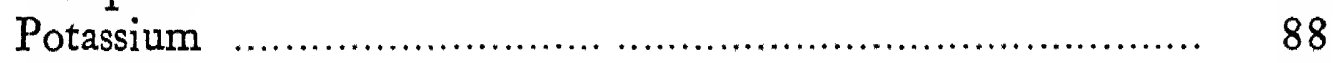

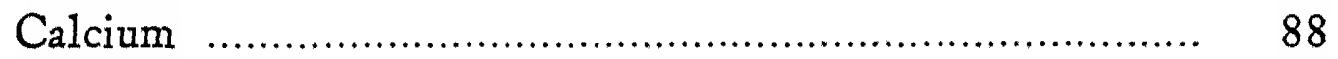

Magnesium ……................................................ 89

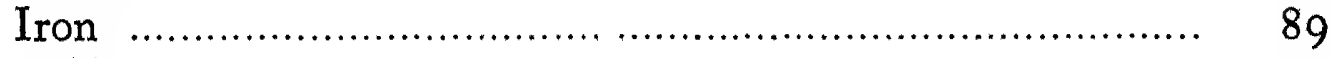

Sulfur ................................................................ 89

The Biological Agencies in the Soil........................................ 9 I

Number of Bacteria in Soils ....................................... 92

Factors Influencing Numbers ........................................ 92

Variation with Depth ............................................... 94

Kinds of Microörganisms ............................................... 95 


\section{The Carbon, Nitrogen, Sulfur and Phosphorus Cycles}

Importance of Bacteria in Cycles .... ............................... 97

The Carbon Cycle ............................................................ 98

The Nitrogen Cycle ............................................... 99

The Sulfur Cycle ........................................................ 102

The Phosphorus Cycle ............................................. $\mathrm{IO}_{2}$

\section{CHAPTER XI \\ Organic Matter and Its Transformation by Bacteria}

Quantity of Organic Matter .................................. 107

Kinds of Organic Matter ............................................. 108

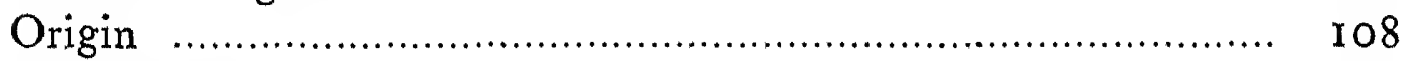

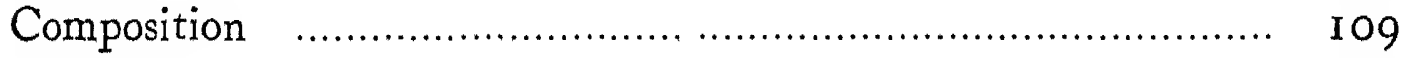

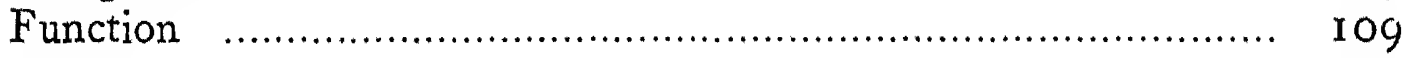

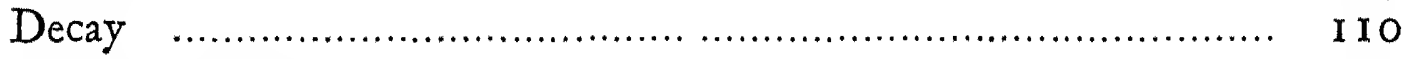

Ammonification ...................................................... II 3

Organisms Causing Ammonification................................ I I 3

Material Ammonified ................................................... I I 4

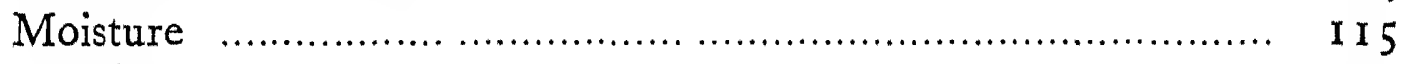

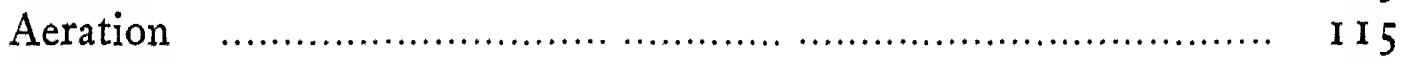

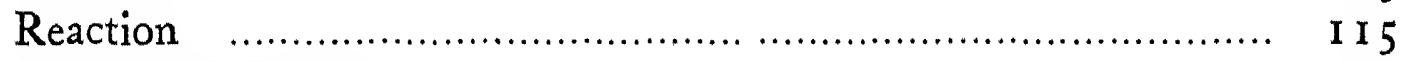

Food Requirements ................................................... I 5

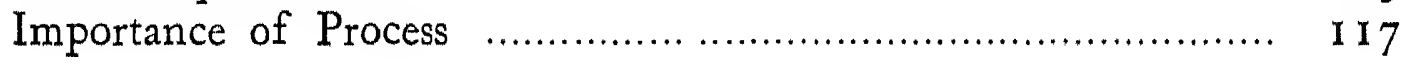

CHAPTER XII

Nitrification

Earliest Developments ................................................ I 8

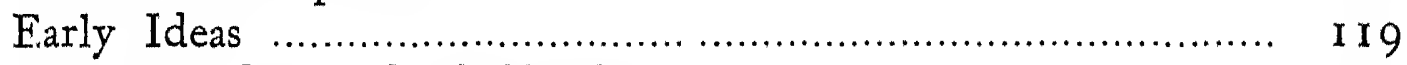

The True Cause of Nitrification ..................................... I 20

Distribution ............................................................... 122

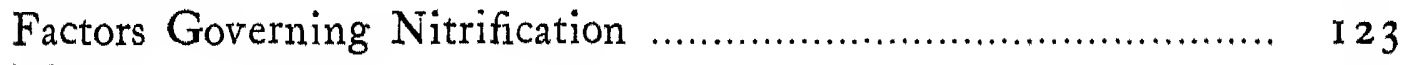

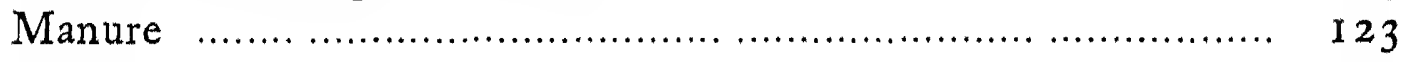

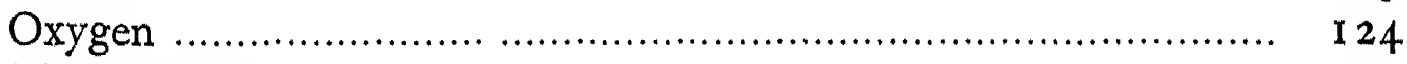

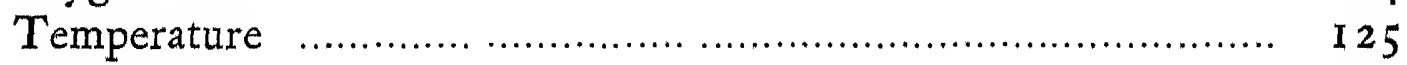

Moisture ............................................................. I 25

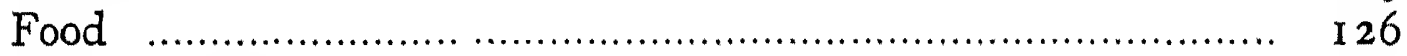

Crop and Fallow ............................................... I 27

Loss of Nitrates ..................................................... 129 
CONTENTS $\quad$ xiii

CHAPTER XIII

PAGES

Why this Loss?

Denitrification

132

Loss of Nitrates from Manure and Soil.................................... I 133

Factors Influencing Denitrification ……................................ I 135

Function of Denitrifiers.................................................... I 36

\section{CHAPTER XIV \\ Non-Symbiotic Nitrogen Fixation}

Development of Our Knowledge ...................................... I 39

Where do Nitrogen Fixers Occur? …..... ........................ I $\mathbf{1}^{2}$

Conditions for Growth ................................................ I 143

What do They Feed Upon? ........................................ I 44

From Whence Their Energy? ......................................... I 44

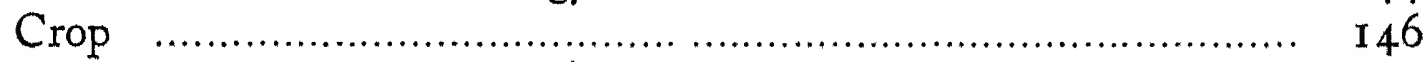

How is the Nitrogen Fixed? ........................................... 147

Properties of Azotobacter .......................................... I 148

Soil Inoculation …................................................... 148

Soil Gains in Nitrogen ........................................... I5 I

CHAPTER XV

Symbiotic Nitrogen Fixation

Belief of the Seventeenth Century ....................................... I 56

Later Work ............................................................. 156

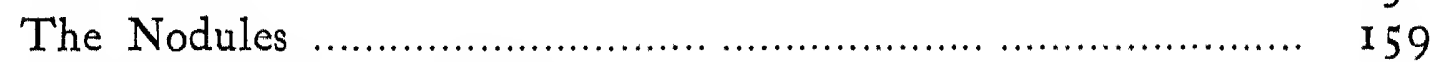

Conditions Favoring Growth ....................................... I60

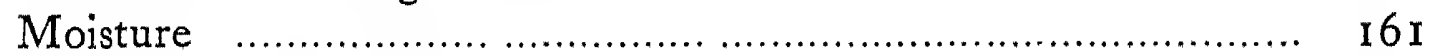

Influence of Fertilizers ............................................. I6z

Legumes Associated with Non-legumes ................................. $\quad 162$

Soil Gains in Nitrogen ................................................. 163

Shall We Inoculate? .................................................. 165

How Inoculate? ......................................................... 167

"Method Involving the Use of One Commercial Culture"....... $\quad$ I68

"Alternative Method" ..................................................... I69

Hope of the Future ................................................ 169

\section{CHAPTER XVI \\ Legumes and Soil Fertility}

Essential Elements ....................................................... I I I

Plant Food Added by Legumes ......................................... 172 


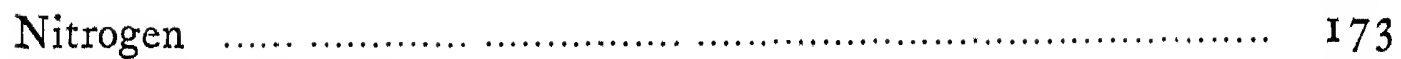

Rothamsted Rotation ................................................. I 74

Nitrogen Obtained from Atmosphere by Legumes................... I $\quad$ I 5

Distribution of Nitrogen in Legumes ............................... I 76

Legumes Feed on Nitrates .................................... I 77

Nitrification in Soil ............................................... 178

How Maintain Soil Nitrogen ....................................... I 80

What is Cellulose? ................................................... I 82

Cellulose in Soil .................................................... I8

Early Observations ................................................. $\quad 184$

Discovery of the Organisms.......................................... I85

Products ...................................................................... I 86

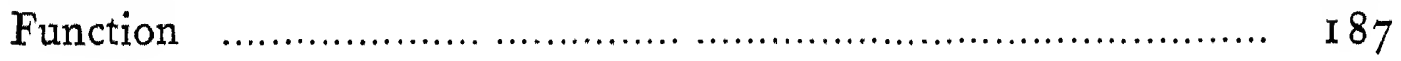

CHAPTER XVIII

Influence of Soil Alkali on Bacteria

Kinds of Alkali ........................................................... I 9 I

Kind and Number of Microörganisms in Alkali Soil ............... I 9 I

Stimulation of Bacteria by Alkali ...................................... I 92

Toxicity of Alkali Salts ................................................. I 94

Variation in Toxicity ............................................ I95

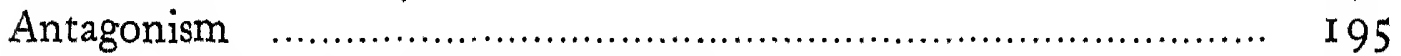

How to Overcome Poisonous Action................................... $\quad$ I 97

Neutralizing Salt ............................................... I 97

Removing the Salt ......................................... 198

CHAPTER XIX

Influence of Heat and Poisons on Soil Bacteria

Heat .................................................................... 200

Antiseptics ........................................................... 202

How Account for These Conditions................................ . 203

Metallic Poisons ................................................... 206

Ammonifiers ................................................................ 206

Nitrification ..................................................... 207

Nitrogen Fixation .................................................. 207

How does the Arsenic Act? ............................................ 208 
CHAPTER XX

Munure

Composition ....................................................................... 2 I0

Losses from Manure .................................................... 212

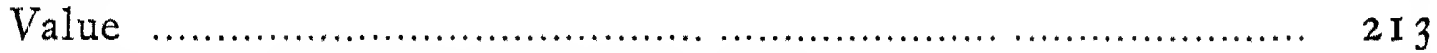

Influence on Number of Bacteria in Soil......................... 2 I 5

Ammonification ................................................. 2 I 5

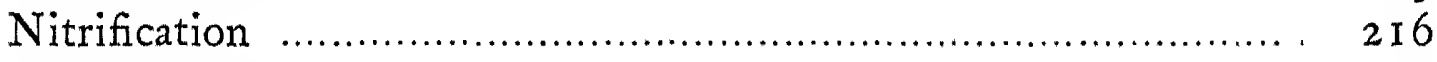

Green Manure .................................................. 217

CHAPTER XXI

The Inflience of Irrigation Water on Soil Fertility

Ammonification ..................................................... 219

Nitrification ............................................................. 220

Other Acids ............................................................... 22 I

Salts Carried from Soil by Water ....................................... 221

Loss of Nitrogen ................................................... 222

Plant Food Carried to a Soil by Irrigation Water................... 223

Nitrogen Fixation .................................................... 224

Alkali of Water .................................................. 225 



\section{ILLUSTRATIONS}

PAGE

Fig. I. The first drawings of bacteria by Leeuwenhoek......... 2

Fig. 2. Drawings of bacteria after Pasteur ( 1864 )................. 5

Fig. 3. Illustrating the close relationhsip of bacteria to the blue-green algae ...................................... I I $_{3}$

Fig. 4. The normal types of bacteria............................ 23

Fig. 5. Large bacilli ............................................. 24

Fig. 6. Diplococci ............................................. 25

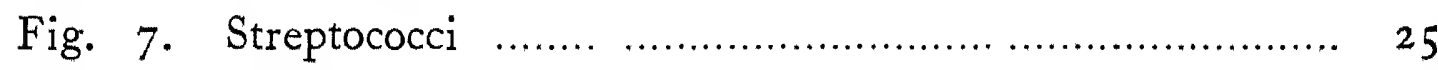

Fig. 8. Sarcina ...................................................... 26

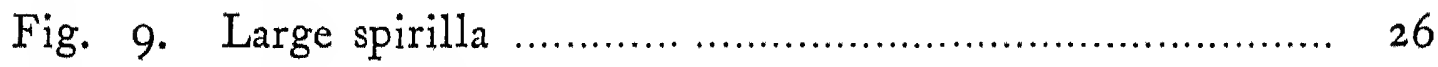

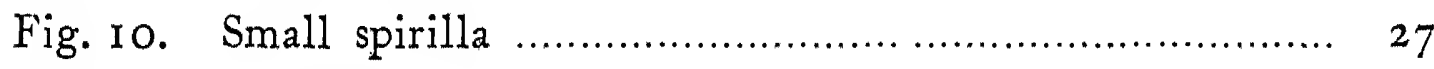

Fig. Ir. Involution forms of bacilli................................ 27

Fig. I2. Successive steps in the formation of the various groupings of the cocci........................................... 28

Fig. I 3. Bacteria with flagella at one pole.......................... 29

Fig. I4. Bacteria with flagella at both poles........................ 30

Fig. I 5. Bacteria with flagella surrounding body.................. 3 I

Fig. 16. Capsulated bacteria ..................................... $3 \mathbf{I}$

Fig. 17. Types of spores ........................................ 32

Fig. I 8. Yeast cells ............................................... 34

Fig. I9. Different types of yeast cells............................ 34

Fig. 20. A mold colony ........................................... 35

Fig. 21. Sterilizers used in bacteriology............................. 43

Fig. 22. Colonies of bacteria on agar-agar culture media.......... 44

Fig. 23. Etching of marble by plant roots .......................... 79

Fig. 24. Relationship between crop and bacteria in a soil......... 93

Fig. 25. Illustrating nitrogen cycle in nature..................... I 0 I 
Fig. 26. Illustrating the relationship between bacterial activities in a soil and crop yield ................................ I I 6

Fig. 27. Nitrifying bacteria .................................... I 2 I

Fig. 28. Nitrifying bacteria …................................. I 2 I

Fig. 29. Nitrogen produced by various processes....................... I 39

Fig. 30. Clostridium pasteurianum …................................. I4 I

Fig. 31. Azotobacter cells ............................................ I 48

Fig. 32. Pigments produced by Azotobacter .............. facing page 148

Fig. 33. Nodules on soy beans ......................................... 159

Fig. 34. Influence of legumes on crop yield.......................... 164

Fig. 35. Effect of inoculation on alfalfa ............................. 166

Fig. 36. Colonies of cellulose ferments ............................... I 86

Fig. 37. Cellulose ferments ......................................... 187

Fig. 38. Alkali soils ...................................................... 190

Fig. 39. Vegetation on alkali and alkali-free soil..................... I9I

Fig. 40. Influence of alkali on growth of crimson clover .......... 198

Fig. 4r. Arsenic obtained from various soils............................ 206

Fig. 42. Beans grown on arsenic-treated soil .......................... 208

Fig. 43. Beets grown on manured and unmanured soil.............. 2 I4

Fig. 44. Relationship between nitrification and crop yield....... 217

Fig. 45. Soil injured by alkaline water................................. 226 


\section{BACTERIA IN RELATION TO SOIL FERTILITY}

\section{CHAPTER I}

\section{DEVELOPMENT OF SOIL BACTERIOLOGY}

\section{B}

ACTERIAL life probably antedates all other on this planet.

Walcott claims to have found fossil bacteria in geological formations the age of which is estimated to be 33,000,000 years. It is certain that they were the pioneers who gained a precarious foothold on the bleak, primitive rock and manufactured acids which in time produced an abode fit for the growth of higher plants. Although bacteria were not known to man until the perfecting of the compound microscope in the last quarter of the seventeenth century, yet they manifested themselves centuries before. Even at the dawn of written history, decay, fermentation, putrefaction, and disease were familiar phenomena, but varied and interesting are the theories evolved to account for the observed facts.

Discovery of Bacteria.-Anton van Leeuwenhòek ( $1632-$ I723), a Dutch linen-draper, often called the father of bacteriology, during his life, contributed to the British Royal Society, one hundred and twelve papers dealing with various scientific topics. $\mathrm{He}$ also manufactured scores of microscopes many of which were superior to any made before. With these he examined various things-raindrops, saliva, and many putrefying substances. $\mathrm{He}$ found in every case, living, moving animalcules which prior to his time had been unrecognized. We can imagine his joy and surprise from his statement: "I saw with wonder that my material contained many tiny animals which moved about in a most amusing fashion. The largest of these, A (Fig. I) showed the liveliest and most active motion, moving through the water or saliva 
as a fish of prey darts through the sea; they were found everywhere, although not in large numbers. A second kind was similar to that marked B (Fig. I) which sometimes spun around in a circle like a top. These were present in larger numbers and sometimes described a path like that shown in C to D (Fig. I.).

A third kind could not be

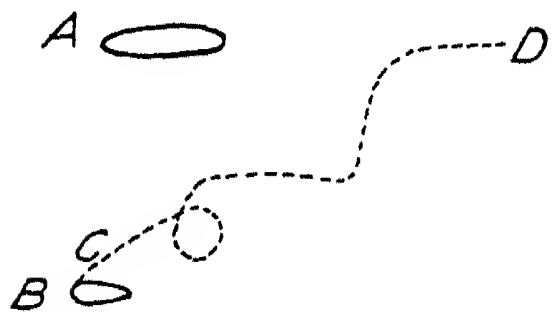
distinguished so clearly; now they appeared oblong, now quite round. They were so very small that they did not seem larger than the bodies marked $\mathrm{E}$, and besides they moved so rapidly that they were continually running into one another. They looked like a swarm of gnats or flies dancing about together. I

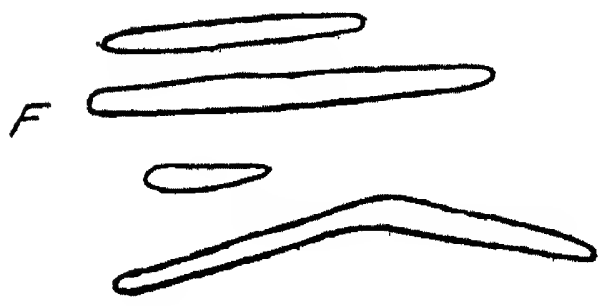

FIG. I.-The first drawings of bacteria by Leeuwenhoek. The dotted line "C-D" indicates movement of the bacteria. had the impression that I was looking at several thousand in a given part of water or saliva mixed with a particle from the teeth no larger than a grain of sand, even when only one part of the material was added

to nine parts of water or saliva. Further, the greater part of the material consisted of an extraordinary number of rods, of widely different lengths but of the same diameter; some were curved, some straight as shown in F; they lay irregularly and were interlaced. Since I have previously seen animalcules of this same kind in water, I endeavored to observe whether there was life in them, but in none did I see the smallest movement that might be taken as a sign of life." Some of them he considered traveled with the speed of lightning and even "tore through each other."

This patient worker, supplied with a microscope of his own 
make, gives to us a fairly accurate description of these minute forms of life. However, it did not awaken the world to even a faint realization of the marvelous invisible forms of life which were present in everything either as a blessing or as a curse. It did, however, revive a discussion which waxed long and furious as to whether life can spring spontaneously from dead matter or is always the offspring of preexisting parents.

Spontaneous Generation.-Theories as to the origin of life are as old as the human race. The doctrine of spontaneous generation is one of them. Many ancient writers fancifully portrayed the transforming of dead into living matter. The Greek philosophers taught it. Aristotle said that "animals sometimes arise in soil, in plants, or in other animals." Cardan (I5OI1576) wrote that water gives rise to fish and animals and is also the cause of fermentation.

As late as the sixteenth century a famous chemist and physicist, van Helmont (1577-1644), stated that mice can be generated spontaneously by placing some dirty rags together with a few grains of wheat or a piece of cheese in a dark place. Today the same philosopher's method of producing scorpions is amusing. "Scoop out a hole in a brick, put into it some sweet basil. Lay a second brick upon the first so that the hole may be imperfectly covered. Expose the two bricks to the sun and at the end of a few days the smell of the sweet basil, acting as a ferment, will change the herb into a real scorpion."

An Italian, Buonanni, tells of a wonderful change which he claims to have witnessed. Rotten timbers which he rescued from the sea produced worms; these gave rise to butterflies; and strangest of all, the butterflies became birds and flew away.

Everyone took it as a self-evident fact that maggots originated without parents from decomposing meat or cheese, until an Italian poet and physician, Redi (1626-1695), took the simple precaution of screening the mouth of jars containing meat so that flies could not enter. Flies were attracted by the odor and deposited their eggs on the gauze, and it was from these that the so-called "worms" arose. 
The theory of the spontaneous generation of mice, scorpions, and maggots had been proven incorrect. But how about these microscopic animalcules which had just been discovered? Surely they could develop directly from dead material. For anyone provided with this new instrument, the microscope, could easily demonstrate for himself the spontaneous generation of microscopic eels in vinegar or produce myriads of different and interesting living creatures in simple infusions of hay or other organic material.

Needham evolved the theory that a force called "productive" or "vegetative" existed which was responsible for the formation of organized beings. The great naturalist, Buffon ( I 707-I 788 ), elaborated the theory that there were certain unchangeable parts common to all living creatures. After death these ultimate constituents were supposed to be set free and become very active, until with one another and still other particles they gave rise to swarms of microscopic creatures.

Needham, a Catholic priest, in 1745 took decaying organic matter and enclosed it in a vessel. This he placed upon hot ashes to destroy any existing animalcules. On examining the contents of the flasks he found microörganisms which were not there in the beginning. Later in 1769 Spallanzani repeated the work, as he felt that Needham had not exercised sufficient care and that the organisms entered from the outside. The latter boiled the material for one hour and kept it in hermetically sealed flasks. He wrote: "I used hermetically sealed vessels. I kept them for one hour in boiling water, and after opening and examining their contents after a reasonable interval, I found not the slightest trace of animalculæ, though I had examined the infusion from nineteen different vessels."

But the believers in the theory of spontaneous generation were not convinced, for they claimed that the boiling altered the character of the infusion so that it was unable to produce life. Voltaire, with his characteristic satire, took up the fight at this point and ridiculed the operations of the English clergy who had engendered the eels in the gravy of boiled mutton, and he wittily 
remarked: "It is strange that men should deny a Creator and yet attribute to themselves the power of creating eels." But this was a controversy to be settled not by ridicule but by experimental evidence.
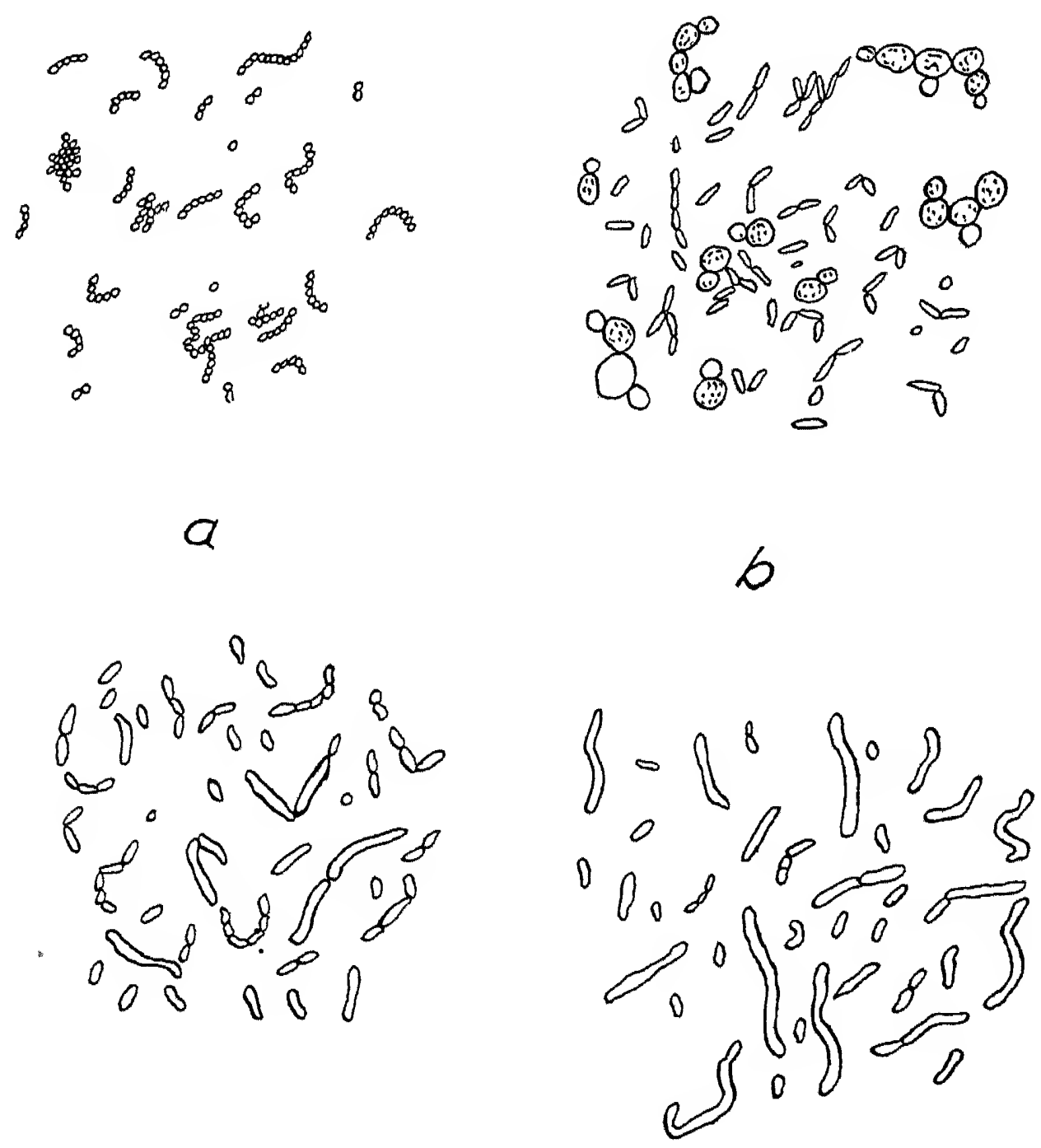

\section{c}

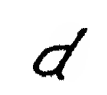

FIG. 2.-Drawings of bacteria after Pasteur (1864)-(a) urea bacteria. (b) lactic acid bacteria and yeast, (c) and (d) butyric acid bacteria.

Spallanzani answered this by cracking one of the flasks so that air could enter. Decay soon set in. Even this was not sufficient to overthrow a popular belief, for the claim was made that the sealing of the flasks excluded the air and air was essential to the 
generation of these forms of life. This objection was answered by the work of many an ingenious investigator. Schulze, in 1836 , passed air through strong acids and then into boiled infusions and failed to find any living organisms in the infusion, whereas Schwann passed the air through highly heated tubes with the same results. This was criticized by their opponents who claimed that the chemical alteration of the air subjected to such drastic treatment had been responsible for the absence of bacteria in the infusion. The work of Schroeder and Dusch (1853) was more convincing, for they found that it was sufficient to stopper the bottles with cotton plugs; the air passed in, but the microörganisms were held back by the cotton and the contents of the flasks kept.

Every now and then the contents of a flask would spoil, even after it had been carefully stoppered and boiled. This remained a stumbling block in the way of those who maintained that life sprang only from life, until in the year 1865 when Pasteur demonstrated that many bacteria may pass into a resting stage, and while in this condition they will withstand conditions which quickly kill them while in the vegetative stage. Eleven years later Conn of Breslau investigated very carefully organisms in this resting or spore stage, and today we know forms of microörganisms which will withstand boiling water for sixteen hours without being killed, and others even resistant enough to endure for many hours a ro per cent solution of carbolic acid.

Since the dawn of history man has been interested in the wonderful process known as fermentation, but although many an ingenious theory has been formulated to explain it little more than theory existed until the classic works of Pasteur on fermentation appeared about I837. Pasteur claimed that all forms of fermentation were due to the action of microscopic organized cells. An idea such as this, even at this late date, did not go unchallenged; for we find no less illustrious workers than Helmholtz and Liebig opposing it. The latter even scoffed at such an idea, writing: "Those who pretend to explain the putrefaction of animal substance by the presence of microörganisms reason very much like a child who would explain the rapidity of the Rhine by attributing 
it to the violent motions imparted to it in the direction of Burgen by the numerous wheels of the mills of Venice". However, Pasteur's carefully planned experiments soon demonstrated that without microörganisms there would be no fermentation, no putrefaction, no decay of any kind except by the slow process of oxidation.

If there were any doubts left in the minds of the scientific world as to the fallacy of the theory of spontaneous generation, after the work of Pasteur, they were dispelled by the work of Tyndall. Tyndall proved that in an atmosphere devoid of dust, as on the tops of mountains and in some ingeniously constructed boxes used by him, perishable substances, such as beef tea, if sterile, when placed in such an atmosphere, will keep for an indefinite period.

We have found the two great landmarks in the history of bacteriology to be the discovery of bacteria by Leeuwenhoek and the recognition by Pasteur that putrefaction, fermentation, and decay are due to microörganisms which have parents as do other plants or animals. A third great advancement was made in 1876 when Weigert used some of the anilin dyes to stain the body of bacteria, thus making it possible to see and study the shape and structure of organisms which may occur in body tissue, soils, milk, and water. Still a fourth milestone on the path of bacteriological research was passed when the immortal Robert Koch devised the gelatin-plate method for obtaining pure cultures of bacteria. $\mathrm{He}$ added to liquefied portions of sterile gelatin small quantities of the material containing the bacteria which he wished to study, shook the material to distribute it uniformly throughout the liquid gelatin and spread it on a covered sterile plate. The bacteria were fixed in isolated spots. The bacteria multiplied until they became visible to the naked eye, just as a clump of trees in the valley may be seen while a single tree may be invisible from the distance. These colonies, each the offspring of a single cell, could furnish only one kind of bacteria. These could be fished out with a sterile platinum needle, studied under the microscope or grown in different media, or perchance in soil or the body of susceptible animals 
until their shape, function, and various other characteristics were understood.

Many writers take the date 1882 as the one in which this advance was made as the birth of the new science-bacteriology.

Soil Bacteriology.- It was a well-accepted maxim with the older writers on agriculture that "corruption is the mother of vegetation." One of the most illustrious of their number, Liebig ( 1855 ), taught that plant and animal tissues decayed in the soil with the formation of ammonia which he considered so essential to plant growth. Part of this he taught was transformed into nitric acid which also served as plant-food.

Long before the nature of the process by which plant residues and manures were transformed into nitrates was understood the method was used to supply the large quantities of gunpowder consumed in the almost incessant wars of Europe. In the eighteenth century the artificial production of saltpetre in beds of decaying organic matter reached a high degree of perfection. Especially was this true in Sweden, Switzerland, and France, where nitrates were collected as a part of each farmer's tax. In the year 1777 the French Government issued special instructions for its manufacture in which there was stressed the form of pit to use, the covering of the organic matter, the arrangement for the free entry of air, the optimum amount of moisture, and the necessity of a base to neutralize the acid as formed.

Boussingault in the years between 1860 and 1878 became interested in the natural-occurring "nitre beds"-especially in those of Peru and Ecuador. He did work which established the origin of the nitrate as the organic matter of the soil. It was considered, however, that the transformation was a chemical change produced through the interaction of ozone or active oxygen on the ammonia coming from the organic matter. The soil was supposed to act as a catalyzer, thus accelerating the speed of the reaction.

During the sixties and seventies great advances had been made in bacteriology. It had been definitely established that bacteria bring about decay, putrefaction, and fermentation, and it was 
conceivable that they were the active agents in changing these within the soil. Pasteur had expressed the opinion that nitrification, the changing of ammonia into nitrates, was a bacterial process. Nothing definite was known on the subject until 1877 , when Schloesing and Müntz were surprised by the pecularity in action of sand filters used in purifying sewage.

A continuous stream of sewage was allowed to trickle down a column of sand and limestone at a rate such that it required eight days to pass. The first twenty-one days the ammonia in the sewage was unaffected. Then it began to appear as nitrates, and in time only nitrates issued from the filter. If it were a chemical process, nitrates should be found at once. Why must twenty-one days elapse before the ammonia was transformed into nitrates? In attempting to answer this, they found that the process could be stopped by the addition of chloroform and started by adding the extract of fresh soil. Nitrification was thus shown, to use their expression, to be due to organized ferments.

The succeeding thirteen years represent the history of a race among the leading scientists of Europe and America to determine to whom should go the honor of first obtaining and studying in pure culture the microörganisms which possessed this important property of transforming ammonia into nitrates.

Warington of England proved that no matter what compounds of nitrogen are supplied to a plant as manure, they are rapidly transformed within the soil into nitrates. Furthermore, he found that ammonia is first changed to nitrite and then into nitrate, but was unable to obtain pure cultures of the organism bringing about either reaction.

However, up to the time Winogradski took up the subject, all attempts to isolate such organisms had failed. After long trying experiments which demonstrate the keen, untiring ingenious, nature of this investigator, he gave to the world nitrifying organisms. He found they would not grow in ordinary media as had been used by previous workers, but the media must be free from organic matter.

It has been known for generations that uncropped soil increases 
in fertility and that legumes differ from other plants in their nutritive requirements. Less ancient, however, is the knowledge that uncropped soil may gain in nitrogen or that legumes with the aid of bacteria may get their nitrogen from the soil.

In the middle of the nineteenth century Boussingault wrote: "Vegetable earth contains living organisms-germs-the vitality of which is suspended by drying and re-established under favorable conditions as to moisture and temperature." He also hinted at the fact that the microörganisms may take nitrogen from the air and so change it that it may be used by the growing plant. $\mathrm{He}$ spread out thinly $120 \mathrm{gm}$. of soil in a shallow glass dish and for three months moistened it daily with water free from nitrogen compounds. At the end of the time he found that it had gained nitrogen but had lost carbon. Thirty years later Hellriegel and Wilfarth solved the apparently hopeless problem of the nitrogen nutrition of leguminous plants. Bacteria live in little nodules on the roots of legumes and manufacture nitrogen compounds which they give to the higher plants in exchange for carbohydrates and other nutrients needed by bacteria. Since then we have learned much concerning the relationship of plants to free and combined nitrogen of the air and the soil.

In I90 I Beijernick discovered large yeast-like microörganisms which live free in the soil and take from the atmosphere nitrogen and build it up into complex compounds within their bodies. Every year since this date the number of microörganisms which have been found to possess this property has been added to, untrl today scores of organisms possessing this important property are known.

Terrific battles are being waged in the soil between the microscopic plants and the microscopic animals. This is the conclusion reached by Russell and Hutchinson in 1909. Since this date each year has added new knowledge concerning organisms already known or else added new ones to the list of beneficial organisms, until today we know that the soil is teeming with organisms most of which are beneficial. Some of them, however, are without significance, and a few of them are injurious. They not only 


\section{DEVELOPMENT OF SOIL BACTERIOLOGY II}

deal with nitrogen and organic matter of the soil but they act on sulfur, forming sulfuric acid; they form acids which liberate phosphorus, potassium, calcium, and the many other foods needed by the plants. It is the problem of the worker in soil bacteriology to learn how to speed up the work of the beneficial and to suppress or weed out the injurious. Advances have been made in this realm, but for the most part it is a virgin field which awaits the coming of the untiring worker who cares to thrust in his sickle and reap. For truly the harvest will be rich enough to satisfy the most fastidious. 


\section{CHAPTER II}

\section{BACTERIA AND THEIR ROLE IN NATURE}

The telescope revealed to the inhabitants of this globe the vastness of the universe, and the enormous number, the great size and complexity of the planets which compose it. The astronomer spends hours studying this complex aggregate. On the other hand, the microscope has revealed an enormous number of objects which before its time we knew only by the many changes which they produced. We may say that the telescope has revealed the infinitely large, the microscope the infinitely small. One group of the minute organisms revealed by the microscope we call bacteria.

What are bacteria? Where do they occur? What are their functions? Are they some of the plagues liberated from Pandora's casket to torment the human race? Is it possible that some microbes are beneficial or actually essential to man's welfare? These with many others are the questions which crowd into the mind on hearing the term bacteria. It is the province of this chapter to consider briefly some of these questions.

What are Bacteria?-To the layman the terms bacteria and microbe usually suggest a minute animal, and we of ten find them referred to as "bugs." On examining them we find that they have many of the characteristics of animals. They are devoid of green coloring matter, chlorophyll, and hence are compelled to live upon complex food as do the animals. Many of them have the power of independent motion. These facts have lent force to the suggestion that bacteria are true animals. Their general form, their methods of growth, their formation of threads and spores, and their similarity in general to some of the lower forms of plant life, green algx, have caused the biologist to class them as plants. Long before these simple forms of life, bacteria, were 
known the terms plants and animals were invented to distinguish familiar living objects such as elephants and trees, insects and mosses. Even today we may find one scientist classifying an organism as a plant, whereas another worker may classify it as an animal. However, it is impossible to lay down hard and fast
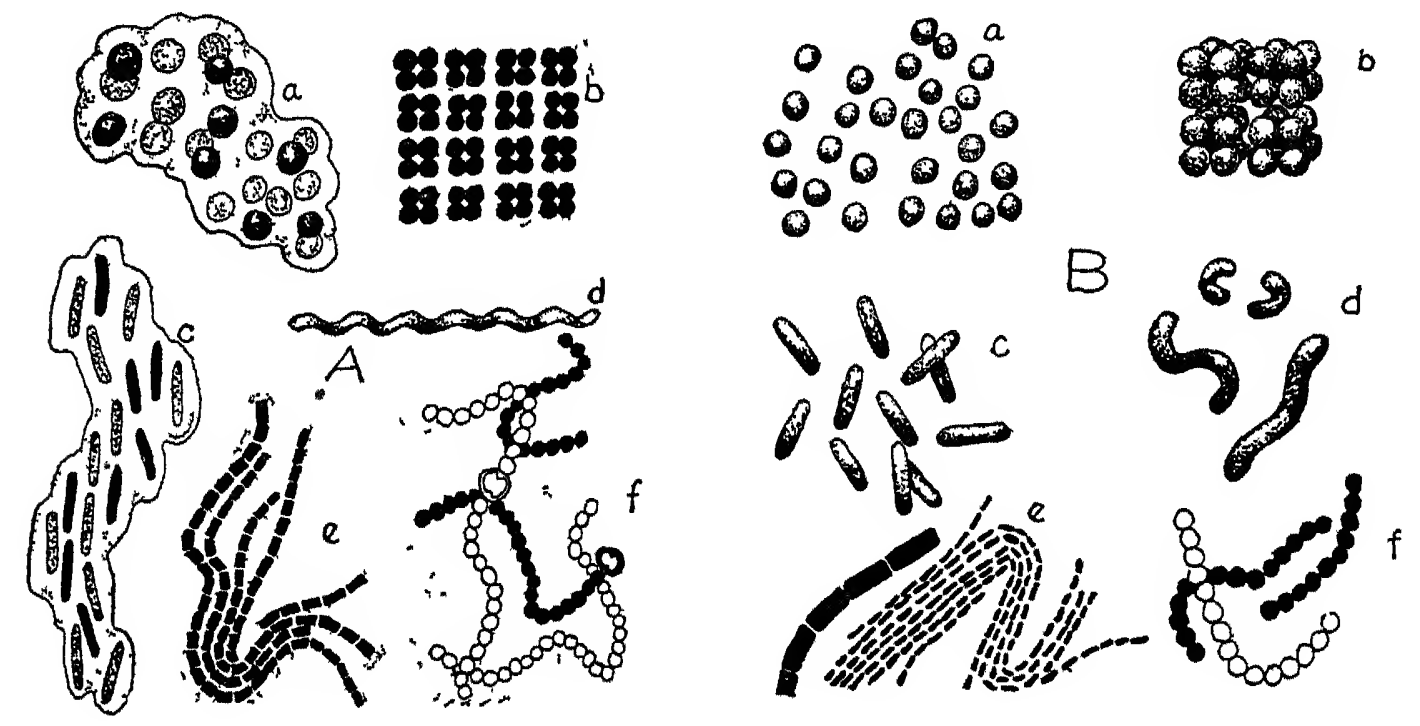

FIG. 3.-To illustrate the close relationship of the bacteria to the blue-green algx. The figures to the left $(A)$ are blue-green algæ, those to the right $(B)$ bacteria. Those forms most closely resembling each other are lettered alike.

$A$, blue-green algæ. a, Aphanocapsa. b, Merismopedia. $c$, Gleotheca. $d$, Spirulina. $e$, Phormidium. $f$, Nostoc. (All adapted from West.)

$B$, bacteria. a, Micrococcus. $b$, Sarcina. $c$, Bacillus. $d$, Spirillum. $e$, Bacillus in chains. $f$, Streptococcus. (After Buchanan)

rules which distinguish some microscopic plants from microscopic animals. At least one scientist has suggested that to obviate this difficulty we create a new kingdom, the Protista, into which we place all such doubtful species. This only brings more difficulty as it becomes necessary to draw two lines of demarcation in place of one.

This has led to the peculiar predicament of students saying that some animals are plants in the botanical department, but on being transferred to the zoological department they have become animals again.

There are four great divisions of the plant kingdom: the seed plants or Spermatophytes, fern plants or Pteridophytes, mosses or 
Bryophytes, and thallus plants or Thallophytes. The thallus plants have neither stems nor leaves, and comprise bacteria, algæ, and fungi. Fungi are simple plants devord of chlorophyll. Yeasts, molds, mildews, smuts, and rusts also fall in this class.

Nor is it an easy task to differentiate nicely between bacteria, yeast, and molds. They may roughly be distinguished from each other as follows: Bacteria are single-celled plants containing nuclear material which is intimately diffused throughout the cell. They multiply by transverse fission-a pinching in two at the center of the organism. Sometimes they are united into long chains which are easily separated into their separate links. Each link is a complete organism.

Yeasts are usually larger than bacteria. They are single-celled organisms and have a definitely organized nucleus. This sets them off from bacteria. They multiply by budding. Buds are small protuberances which appear on the side of organisms which enlarge forming two daughter cells. Molds consist of numerous cells. These are a mass of interwoven threads, each thread being composed of a number of cells which function as a unit.

Where Do Bacteria Occur?-Bacteria are widely distributed, occurring nearly everywhere. They are found in all soils, the number varying with the kind of soil, quantity of plant and animal debris present, moisture, and treatment. They decrease in number with depth, but many soils of Western America contain numerous organisms even at a depth of ten feet. Although they occur in air, it is not their normal home as under ordinary conditions they cannot grow and multiply in it. The number and variety found in air vary with a number of factors-location, moisture, dust, movement of the atmosphere, and the presence or absence of injurious gases. The atmosphere of some high mountains is practically free from bacteria; city and country air also differ from each other in the number and kind of bacteria which they contain. There is a great variation in the air of buildings. They are especially numerous where dust is plentiful.

Most natural waters contain great numbers of bacteria. In sewage and polluted water they are especially numerous. They 
occur only in small numbers or not at all in deep wells and springs. They are numerous in shallow wells, ponds, and streams draining inhabited districts. Often one cubic centimeter of water will contain millions. They are even found in salt lakes and the ocean. In these waters they function even at great depths. The kind and number vary with the composition of the water and the original contamination. Great Salt Lake with its large quantities of common salt contains few organisms, whereas the Great Lakes in the central part of the United States contain many. A turbid stream like the Mississippi which contains the drainage from many cities has a great variety and number of bacteria in opposition to the clear, rapid, flowing water of uninhabited mountainous regions.

Milk, as secreted by the cow, is practically free from bacteria, but when it is drawn from the udder it always contains bacteria. The number and kind vary with specific cows. Some healthy cows may give milk with as few as twenty bacteria in a cubic centimeter, whereas others may give milk with thousands, and diseased cows millions. During the milking process milk receives germs from the coat of the cow, the clothing of the milker, the buckets, strainers, and other things with which the milk comes in contact. Often by the time it reaches the consumer it contains millions of microbes in every cubic centimeter.

Bacteria are found on the surface, but not on the inside of undamaged fruit, and vegetables. In short, all food except that recently cooked contains bacteria, the number and kind varying with the nature and age of the food.

Living as we do in a world which is filled with bacteria, we can expect to find them on the surface of the skin and mucous membranes. Usually they live there feeding on the foreign matter of the surface. At times they work down into the pores of the skin and manifest themselves as blackheads, or as the more painful affliction-boils. Normally the infant enters the world free from bacteria, but bacteria soon settle on the skin. They penetrate the nose and mouth; the first respiratory movements and cries carry them into the respiratory passages; and between the 
tenth and seventeenth hour they have reached the intestines. From the minute of birth until the time of death it is a constant struggle between the individual and the microbes. And one individual has jokingly remarked, "Microbes get us at last." This is strictly true, for most individuals die of bacterial diseases long before the allotted three-score-and-ten years have elapsed. Even those who die from accident or old age, their bodies, unless cremated, are decomposed by bacteria.

Ordinarily, the deeper respiratory passages contain few bacteria, but it has been proven that at times even the tuberculosis organism can penetrate with the inspired air to the bottom of the lungs.

On account of its acidity, yeasts and molds flourish better in the stomach than do bacteria. However, at least thirty different kinds of bacteria have been described as occurring in the stomach. Many of these have attracted special attention on account of the belief that their presence may favor or retard other more injurious species.

The intestines on account of their alkaline reaction and the partly digested condition of their contents are a great reservoir of bacterial activity. In the upper part there are few, but by the time the descending colon is reached billions of bacteria are of ten present. Sometimes they constitute one-third of the total dry contents of the intestine. The health of the individual is determined by the number and kind of bacteria, and at least one writer has suggested that our very personality is governed by the microbes we carry about with us.

The normal tissues of plants and the blood of animals are free from bacteria. They are rarely found on certain healthy mucous membranes, such as those of the kidneys, bladder, and lungs. Occasionally they pass through the skin or mucous membrances of the digestive tract, after which they may be found for a short time in the blood. This is especially true during the height of digestion, and we find at this time large numbers of white corpuscles swarming into the intestinal mucosa ready to pick up and devour any bacteria which may enter. In this manner the body 
is protected against invaders. In certain diseased conditions the blood and tissues of man and lower animals become filled with bacteria. Just before and soon after death these bacteria rapidly invade and tear down the body.

What Are the Functions of Bacteria?-Living in a world teeming with bacteria, we naturally ask this question. They swarm on our bodies and in the alimentary tract. Do they help us or would we be better off without them?

It is certain that chickens, frogs, and some other animals, if hatched free from bacteria and fed on sterile food, do not grow normally. Bacteria assist cows, sheep, and horses in their digestion, but it is doubtful if they are essential in the alimentary tract of man. Inasmuch as we live in a world filled with microbes it is not possible to keep them from the stomach and intestines. Moreover, it is known that some are harmless while others are injurious. Some of the harmless ones produce products which inhibit or prevent the growth of the injurious. Hence, considerable attention has been given to a study of the conditions favoring the growth of the beneficial microbes in the alimentary tract of man. The good effects which sometimes follow the use of sour milk and buttermilk are due to their carrying into the intestines beneficial bacteria together with products which favor their growth. Some claim that the rate with which man ages is determined not by the years he has lived but by the microbes which inhabit his digestive tract.

Bacteria play numerous wonderful parts in the many changes going on in this world. This is true to such an extent that it is hard to conceive of our living in a world without bacteria. Examining the soil from which man draws-either directly or indirectly-his clothing, food, and other necessities of life, we find it to be a veritable garden of minute plants which have been at work within it long before man began to till the soil. What a wonderful change they produce in transforming the bleak, barren rock into a fertile field from which the gardener can gather his delicious berries or beautiful flowers, the farmer his golden sheaves of wheat or his deep green nutritious loads of hay! 
Changes in temperature cause small cracks to appear even in the more resistant rocks. Bacteria being of microscopic size soon penetrate these small crevices. Here they produce carbonic and other acids which gradually dissolve away the rock. The organisms act upon even the most minute fragments, reducing them continually to smaller and smaller particles. If one will pick from a fertile soil a bit of rock, it will be found coated with a fine film of these minute plants. They have drawn on it for their food, and at the same time they have rendered it soluble so the wheat, alfalfa, or corn plant can feed upon it. Bacteria continue their work long after the rocks have been changed to soil. Each day they liberate a little more plant-food for the growth of the crop during that day. During the year they are able in a fertile field to liberate enough plant-food for the production of a good crop. When manure is applied to a soil it not only supplies food for the growing plant, but it also carries to the soil beneficial bacteria and supplies those already there with food. These in turn liberate a little more iron, sulfur, potassium, or phosphorus, and the farmer reaps from his soil a bigger and a better crop.

One of the essentials for plant production, and the one which is usually in the soil in the smallest quantities, is nitrogen. This, unless it is applied to the soil in the form of the expensive fertilizer, nitrates, must be prepared for the plant by bacteria. They are the true kitchen maids of the soil, and the farmer finds his crops measured directly by the speed with which they prepare the meal. If they are active and prepare the right food, other things being favorable, there will be a good crop. But if they fail in their work, though everything else may be ideal, yet there is no crop.

An examination of soils has shown that those which are most fertile contain the greatest number of beneficial bacteria. If the soil is rich in plant residues and has the right quantity of water and sufficient heat many bacteria will be found there chang: ing the plant residues into gases and acids which act upon insoluble substances and render them soluble. One group of bacteria changes the plant and animal proteins into ammonia, and one can 
often detect their activity from the odor of ammonia coming from the stables or manure piles.

However, most plants cannot use nitrogen in the form of ammonia; it must be changed into nitrates. This is done by bacteria. One groups feeds upon ammonia and manufactures nitrous acid. Nitrites are poison to plants; hence, if it were left at this stage we would have no plants. Another class of bacteria feed upon the nitrites as fast as they are formed and yield nitric acid. This reacts with the various minerals of the soil. It is now ready to be taken up by the growing plant and manufactured into nourishing food, beautiful flowers, delicious fruit, or fragrant perfumes for the human family.

So far only the plant-food already in the soil and the changes through which it passes have been considered. The farmer, however, is more concerned with the substances his soil lacks and which must be added in order to get good crops. In many cases the lacking element is nitrogen. One notes from the fertilizer quotations that this element will cost fifteen cents a pound or over if purchased in the form of sodium nitrate, ammonium sulfate, or dried blood. On making a simple calculation we find that at this price it would cost fifteen dollars for enough to produce Ioo bushels of corn; eleven dollars for enough to produce 50 bushels of wheat, and seven dollars and fifty cents for enough to produce one ton of alfalfa hay.

In these calculations it has been assumed that one recovers in the form of corn, wheat, or alfalfa every pound of commercial nitrogen which has been applied, which on the face of it can be seen to be an utter impossibility. Hence, we have to look elsewhere to obtain nitrogen for our growing crop. Here also bacteria come to the rescue.

There are seventy-five million pounds of atmospheric nitrogen resting upon every acre of land. None of the higher plants, however, have the power of taking this directly out of the air. One family of plants, the Leguminosæ, in which are included peas, beans, alfalfa, clover, and many others, if properly infected by bacteria, have the power of using this atmospheric nitrogen. Un- 
der this condition and with these plants nitrogen no longer remains the limiting element of crop production. For these microscopic organisms which live within small nodules upon the alfalfa are master chemists. Within their tiny laboratory they can bring about changes which man can imitate only imperfectly with costly machinery and under the action of powerful electric currents. In some of the experiments carried on at the Illinois Experimental Station these minute organisms were found to increase the value of the first cutting of alfalfa hay $\$ 27.80$ an acre, if the nitrogen in the alfalfa be counted only at the same price we would have to pay on the market for an equivalent quantity of nitrogen in the form of a commercial fertilizer! If these crops be plowed under the fertility of the soil would be increased to just that extent. One writer has said of them: "They not only work for nothing and board themselves, but they pay for the privilege." This is strictly true, for all they require is a plant on which to grow and a well-aerated moist soil containing limestone. Their activity is retarded in an acid soil.

There is another class of nitrogen-gathering organisms within the soil which differ from the above in that they live free in the soil and gather nitrogen. Under ideal conditions they may gather appreciable quantities.

It is quite possible that much of the benefit derived from the summer fallowing of land is due to the growth within the soil of this class of organisms which store up nitrogen for future generations of plants. It has been discovered that they are more active and found in greater numbers in such soil. All of the work which the farmer puts upon the soil in rendering it more porous reacts beneficially upon these bacteria because they not only love atmospheric nitrogen and oxygen but they must have them.

Bacteria are found by the thousands in every drop of water in the cesspool and they lie in wait and quickly devour the material which enters. Paper, bone, and wood are quickly changed into gases and ash. The repulsive poisonous substances soon disappear under their magic wand, and it is only a short time until the water again becomes pure. 
Bacteria are the universal scavengers which lick up the dead bodies of plants and animals as completely and nearly as rapidly as fire. Were it not for them the world in time would be filled with never-changing organic matter. The plant residues, trees, and animal bodies would remain in the soil, and with them the carbon which is required by the green plant. Bacteria, in getting their required energy, are continually liberating carbon so that it may start again on its constructive journey. If carbon and nitrogen could but speak, what wonderful tales they would tell! The chemist, the bacteriologist, and the farmer each would be wiser, for many of the changes through which carbon and nitrogen pass due either to the action of the one-celled plants, bacteria, or that of the wheat or alfalfa, are so complex that the scientist even with his apparently magical methods cannot follow them.

Bacteria grow in cream, making churning easier. They give to butter its characteristic flavor. They cause the ripening of cheese, thus giving to it the peculiar flavor in opposition to the insipid taste of the fresh cheese.

These are only a few of the many ways in which bacteria benefit the human race. They are at work in the silo rendering the food more palatable and nutritious for cattle. They give to sauerkraut and pickles their flavor. They take part in the tanning of leather, the retting of flax, the curing of tobacco, and help us in a thousand and one ways which we little suspect. One of the most instructive and interesting tasks set for man is to know and learn how to govern these tiny plants.

Some writers even argue that the disease-producing microbes are beneficial. They slay plants and animals so that the material of which their bodies are composed may be used by opners. It is, however, more logical to consider that they formerly were harmless or that they may have been beneficially growing on the surface of plants and animals and decomposing dead material. Later in the struggle between them and their host some were routed and disappeared, while others became true parasites preying upon plants and animals. These are now the outlaws in bacterial society. 
It is interesting to note that man has learned to turn their poisons against them in the production of vaccines and serums which are used to render man and the lower animals immune to their attacks. 
CHAPTER III

\section{SHAPE AND STRUCTURE OF MICROÖRGANISMS}

The cell is the unit of life. This consists of an outer membrane containing within it a semi-solid mass of protoplasm. Higher plants and animals are composed of millions of these cells.

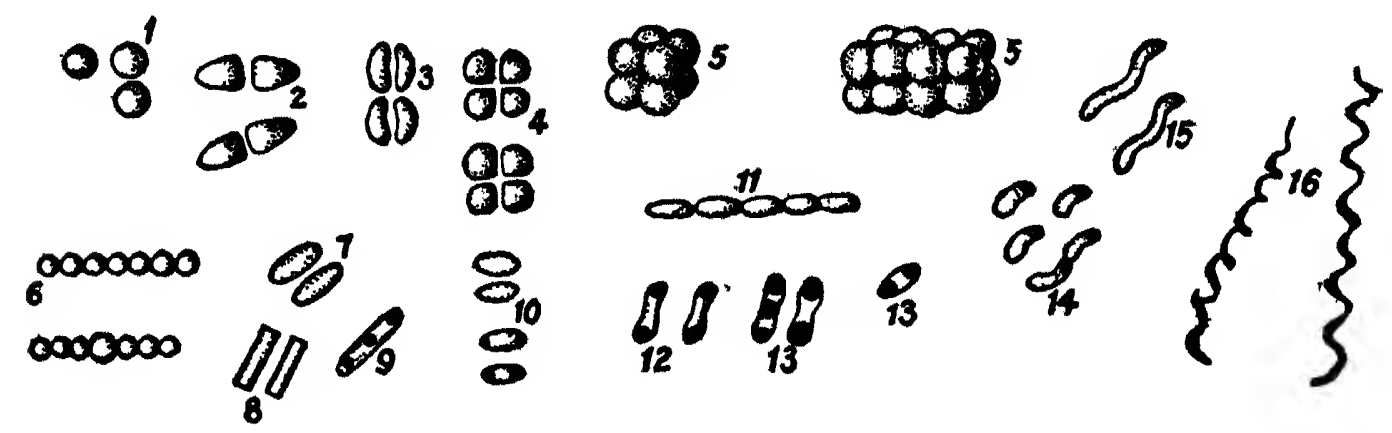

Fig. 4.-The normal types of bacteria. $x-6$, cocci; 7-13, bacilli; $14-16$, spirilla; $x$, micrococcus; 2 and 3 , diplococci; 4 , tetracoccus; 5, sarcina; 6 ; streptococcus (the lower chain includes an arthrospore); 7 and 8 , bacilli, $9, I_{0} I_{2}$ and $r_{3}$, bacilli with various granules, $I I$, streptobacillus; I4, vibrio, 15 , spirillum; $I 6$, spirocheta trenema (after Kendall).

The bacteria are single-celled organisms and in shape have the very simplest conceivable structure. Although there are thousands of bacteria having many wide variations in properties, yet they all have three general forms-rod-shaped, spherical, and spiral.

Shape of Bacteria.-The rod-shaped bacteria are cylindrical organisms which may be compared to an unsharpened lead pencil. Some have rounded ends, others straight, whereas still others have the ends hollowed out. The size also varies, some being so short that it is impossible to tell whether they are rods or globular organisms. All rod-shaped organisms are known as bacilli (singular, bacillus).

Another type of bacteria is the spherical, which may be likened to a baseball or at times to an egg. They are known as 
cocci (singular, coccus). Often when two remain connected together we have a coffee bean-shaped organism or sometimes an organism similar to the head of a lance. 'The cocci may be large or small and group themselves in various ways.

The third group of bacteria are the spirilla (singular, spirillum), and may be likened to a corkscrew. The spiral may be

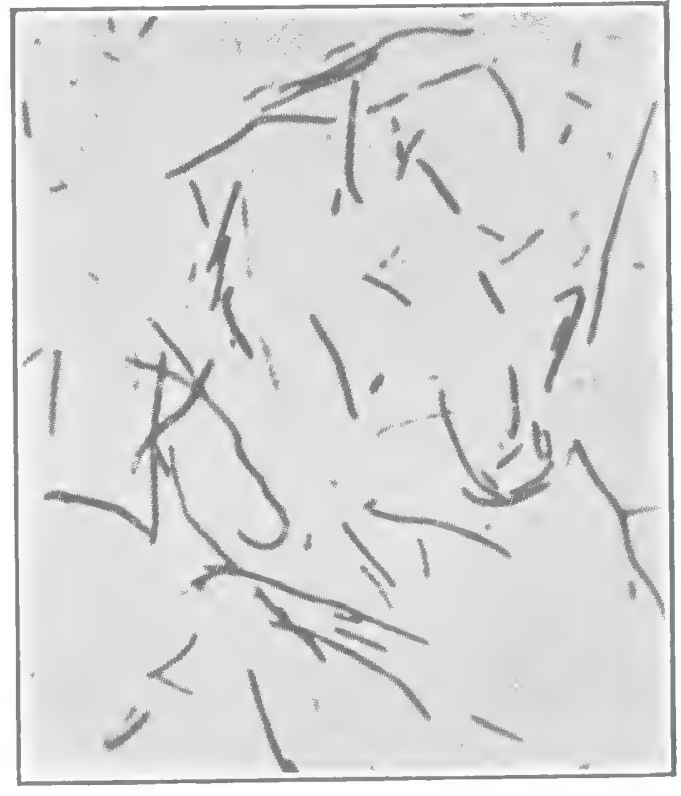

FIG. 5.-Large bacilli (after Harrison). loosely or tightly coiled. There may be one; two, or more coils. At times the organism may be so small and the curve so slight that the organism viewed under the microscope appears to be "comma-shaped."

Roughly speaking, there are about three times as many bacilli known as cocci and five times as many cocci as spirilla.

\section{Variation in Form.-If one} plants the Irish potato he expects to harvest Irish potatoes and not sweet potatoes. So it is with bacteria. If one plants bacilli, the bacilli and not the cocci will grow, or in other words the microscopic plants breed true just as do the higher plants. One may plant a potato and harvest potatoes which vary considerably in size and shape. The same is true in regard to bacteria. There may be a great variation within the same group. Some bacilli may reproduce club-shaped organisms many times larger than the average. This is characteristic of the organism which causes diphtheria, whereas the organisms which grow in the nodules on the roots of alfalfa often take on the form of stars, crosses, and various grotesque shapes. These so-called involution forms of bacteria have been likened to the lame and halt in human society. However, this is hardly an apt illustration, for these peculiar shaped organisms possess all the powers of the normal bacteria, and if they find their way into the body of a plant or animal they 
are just as likely to produce their peculiar effect as are the normal organisms. Hence, we consider their changed shape as being due to environmental conditions which have caused a change only in shape.

Reproduction.-Bacteria quickly decompose the body of an ox. Plants and fruits quickly decay. Millions of tons of organic matter are carried to rivers, lakes, and oceans each year. Bacteria

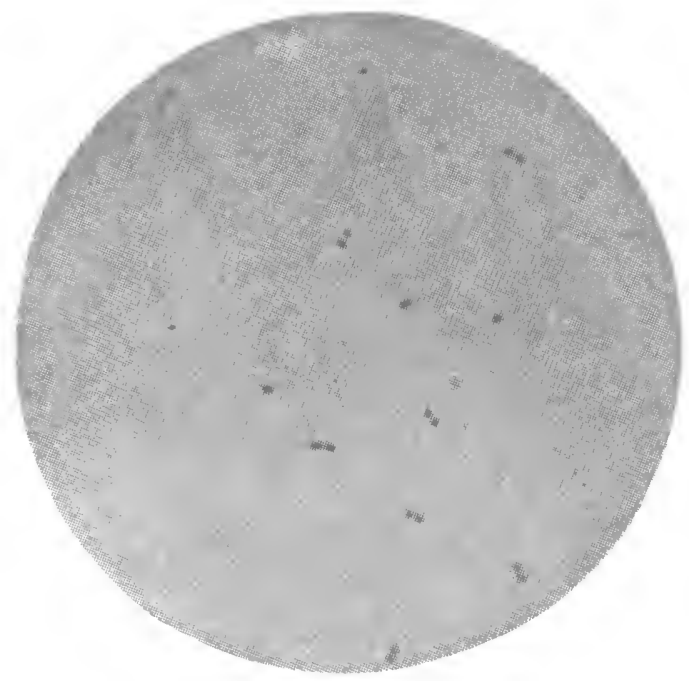

Fig. 6-Diplococci (after Heinemann).

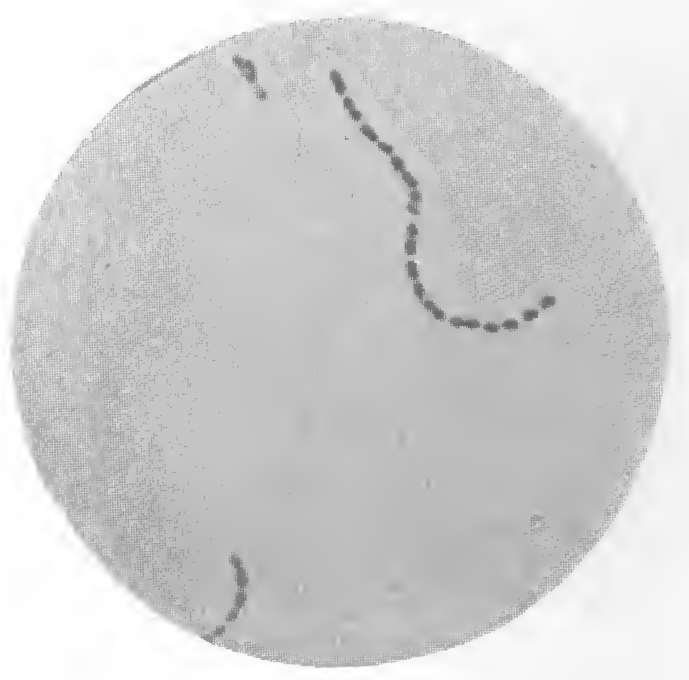

Fig. 7.-Streptococci (after Heinemann).

change all of this into a residual ash and gaseous products. 'They' modify the whole surface of the earth. One may wonder how it is possible for such small plants to accomplish such gigantic tasks. This is due to the rapidity of multiplication. The bacilli grow until they have reached a certain size, then they divide into two daughter cells. These in turn grow to maturity and likewise divide. At times on division the various cells may remain connected together having the appearance of a chain. Such a chain of organisms is called streptobaccilli.

The cocci may divide in one, two, or three planes. When they divide in the same plane and the daughter cells touch at one side only and have the appearance of closely strung beads, they are known as streptococci. They may divide in one plane followed by division in another at right angles to the first, thus forming a 
layer of cells. These are the micrococci. Others may divide in one plane followed by a second division which is not always at right angles so that the organisms form an aggregate which has the appearance of a bunch of grapes. 'These are the staphylococci. Still other organisms may divide in three planes, thus giving rise to packets of cells, a condition similar to that which one would have if four marbles were placed on a level surface and four

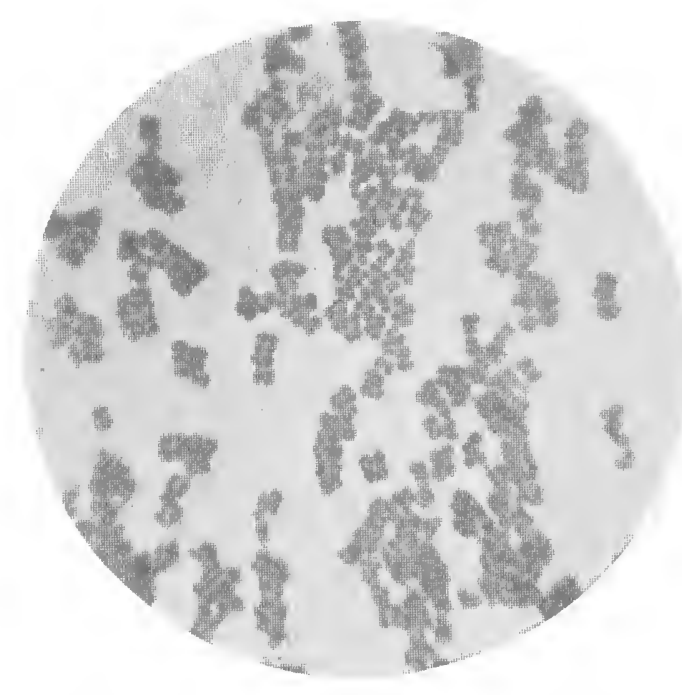

FIG. 8.--Sarcina (after Gruber).

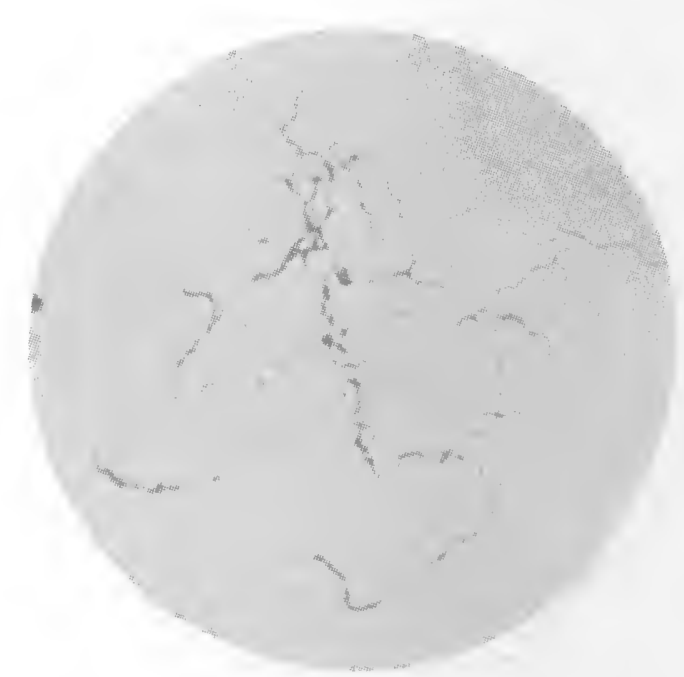

Fig. 9.-Large Spirilla (after Novy).

others placed upon them. These are the sarcina, and they have the appearance of a bale of cotton.

A bacterial generation is taken as the time required for a mature cell to divide and the resulting daughter cells to reach maturity. This process may be completed in half an hour-at times, even more rapidly. Under less favorable circumstances it may be much longer. It has been estimated that if bacterial multiplication went unchecked the descendants of one cell would in two days number $281,500,000,000$, and that in three days the descendants of this single cell would weigh $148,356,000$ pounds! It has been further estimated by an eminent biologist that if proper conditions could be maintained for their life activity, in less than five days they would make a mass which would completely fill as much space as is occupied by all of the oceans on the earth's surface, if the water has an average depth of one mile! 
Even in the face of these assumptions one need not fear, for bacteria have been on this earth, and have been multiplying, probably long before the advent of man, and as yet the earth has not been filled by them. This is due to there being a struggle among them just as there is among higher plants and animals. One knows that if wheat be sown too thickly, none of it will mature. Sometimes it is due to a lack of food, other times to a lack of

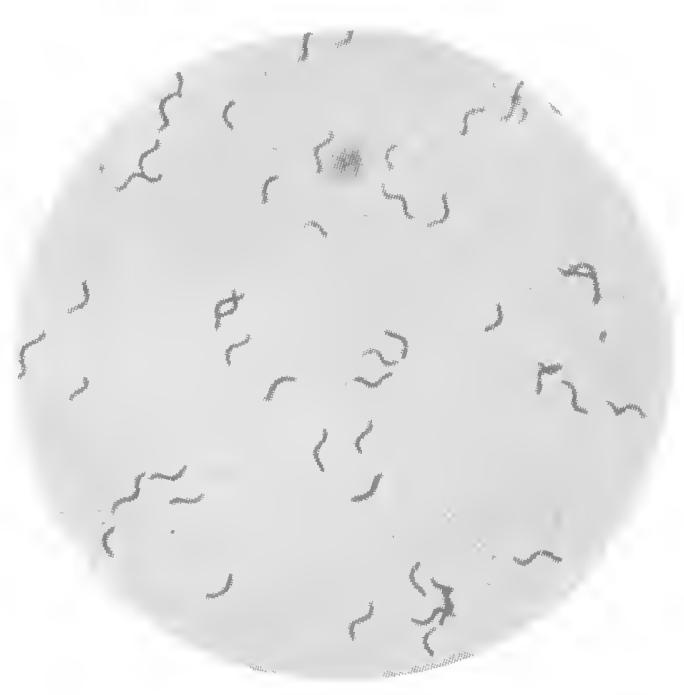

Fig. I o.-Small Spirilla (after Omelianski).

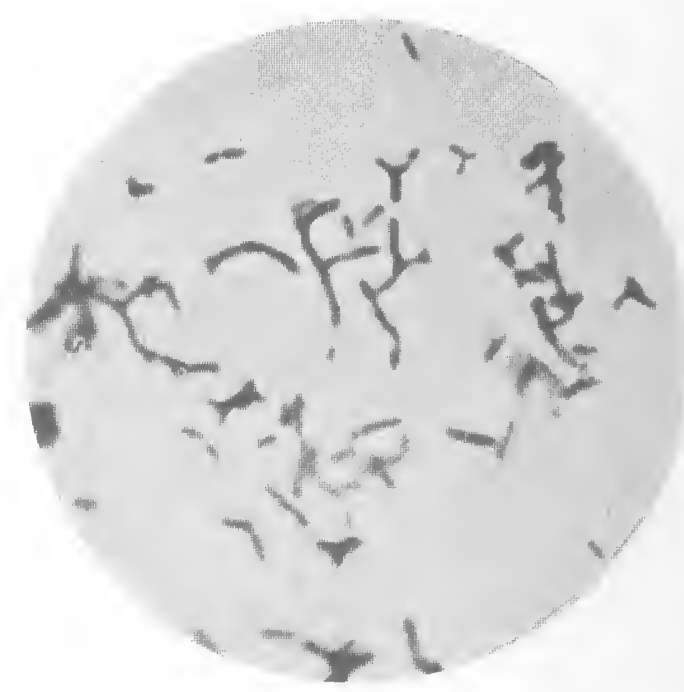

Fig. I1.-Involution forms of bacilli (after Harrison).

sunshine, and at still other times it is due to a lack of moisture which prevents its growth. So it is with bacteria-the food or water may give out. However, more often it is the bacterial products which have accumulated to such an extent that their multiplication is prevented.

Size and Weight.--The unit of measurement in microscopic work is the micron. It is one-thousandth of a millimeter in length, or approximately one-twenty-five-thousandth of an inch. It is represented by the symbol $\mu$. Most bacteria are from 0.5 to 5 microns in length. Some are so small that they cannot be seen with the microscope. Others may be even thirty or forty microns in length. They are smallest in the case of the cocci and largest in the case of the spirilla.

Although there is a great variation in the size of bacteria, all 
are extremely small. Even the largest are not visible to the naked eye. The smallest are beyond the range of our most powerful microscopes. The Pfeiffer bacillus, the organism which was thought to cause influenza, is one of the smallest organisms known. It is a rod-shaped organism, and if placed end to end fifty thousand of them would be required to reach one

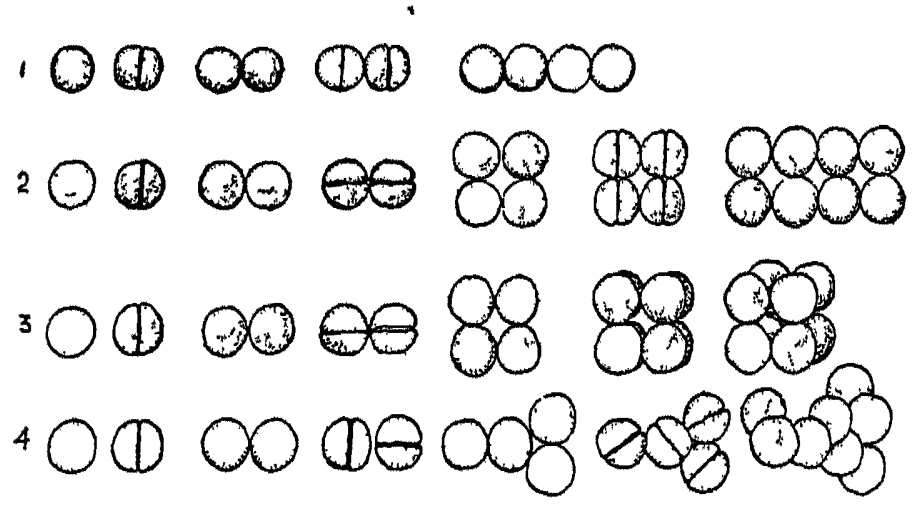

Fig. 12.- Successive steps in the formation of the varrous groupings of the cocci. I, streptococcus. 2, micrococcus, with cells arıanged in tetrads. 3, sacrina 4, staphylococcus (after Buchanan) linear in ch. It would require about fifteen thousand typhoid b a cilli to reach an inch. The organism causing relapsing fever is one of the largest known, and of these it would require fifteen hundred to reach one inch. We of ten magnify bac-

teria one thousand times, and then they appear as dots under the microscope. If we would magnify man to this extent he would be a giant indeed-six thousand feet tall and fifteen hundred feet wide! In a sample of milk containing a billion bacteria in one cubic centimeter there is less than one-thousandth of its volume bacteria. Or, a little globe of bacteria no larger than a drop of water would consist of fifty billion bacteria.

Movement.-If one places a handful of hay in a bottle containing beef tea and allows it to stand in a warm place for twentyfour hours and then examines a drop of it under the microscope it will be found to be filled with living organisms. One notices that all of the particles within the drop are moving-even the small particles of hay. There is a great difference, however, in the way in which they move-some swing back and forth, while others are seen to move swiftly across the field and out of sight. All of the bodies which are thus seen to move rapidly are bacteria which have the power of movement. By appropriate methods it 
has been shown that these bacteria which have the power of independent movement have on their bodies long hair-like appendages. In some, these appendages are many times the length of the body of the organisms. They may be situated at one or both poles or they may even surround the entire body of the organism. It is by the striking of the water with these whip-like appendages that the organisms are able to move. As one examines moving bacteria under the microscope one would think that they were moving with the speed of an express train, but on actually measuring their speed it is found to be an illusion. The cholera organism has been known to attain for a short distance the enormous speed of eight inches per hour! So we need not fear that they will overtake even the slowest by their own means of locomotion.

These organisms have a more rapid and safer way of passing from place to place. Many of them use the common housefly as

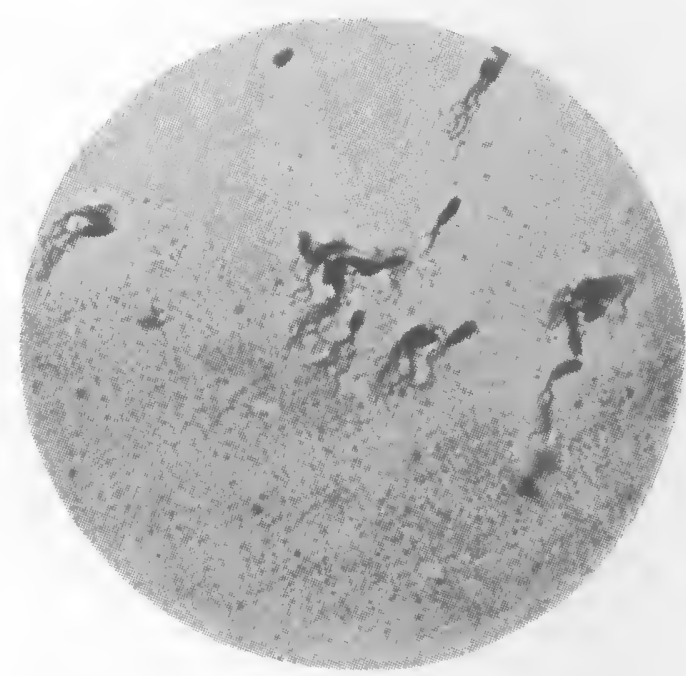

FIG. 1 3.- Bacteria with flagella at one pole (after Gruber). their airship, others the bedbug, while still others will chance a ride with the flea. At other times they find their way into food or on clothing and are transported from place to place. Some are picked up with the particles of dust, but to the disease-producing organism this method of travel is more fatal than is the modern airship to man. The spore-forming organisms, however, may make the journey in this manner with a fair degree of safety. It is not because the fall would hurt these specks of living matter, but when struck by the direct rays of the sun they are killed in a very short time. Many of them cannot withstand even diffused sunlight for any great length of time. Many of them could not have made the journey any great distance even in the dark, for their bodies are about 90 per cent water, and if not clinging to some moist substance they would soon lose sufficient moisture to cause death. 
Some of the disease-producing organisms are found in the mouth (sometimes in individuals apparently healthy) and they can safely make the journey from the lips of one to the lips of another on the common drinking cups. The fingers are continually finding their way to the mouth, and if the saliva were indigo what a blue world it would be! For we find that "the cook spreads his saliva on the muffins and rolls; the waitress infects the glasses and spoons; the moistened fingers of the peddler arrange

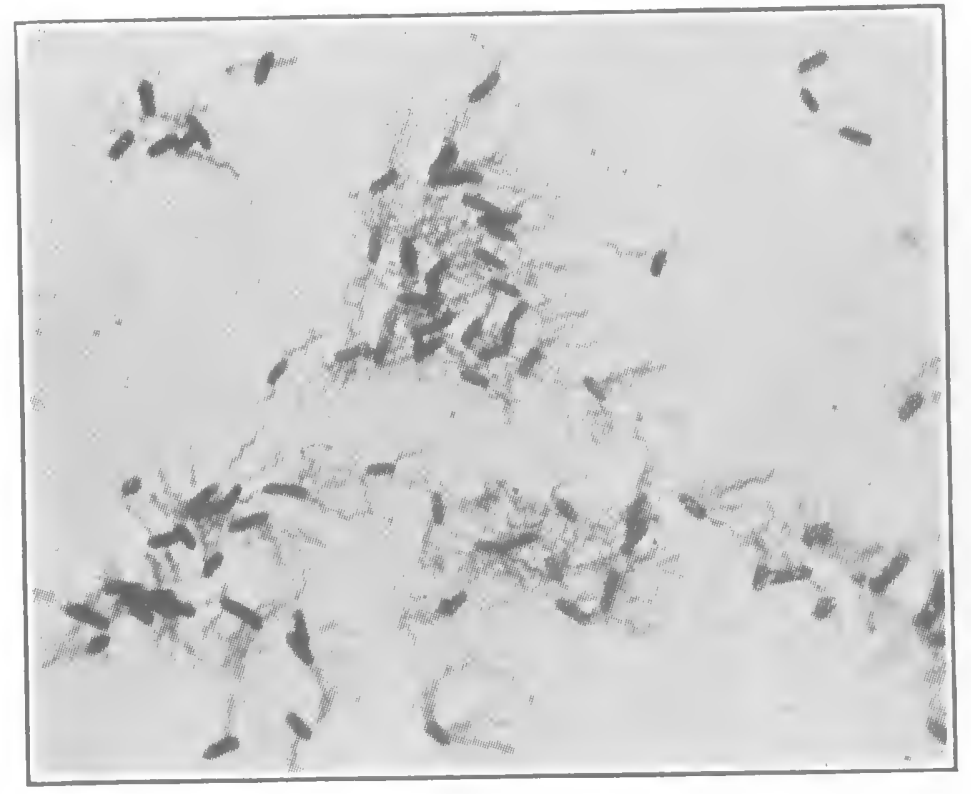

FIg. 14.-Bacteria with flagella at both poles (after Harrison). his fruit; the thumb of the milkman is in his measure; the reader moistens the pages of his book, the conductor his transfer tickets, the 'lady' the fingers of her glove. Everyone is busily engaged in this distribution of saliva, so that the end of each day finds this secretion freely distributed on the doors, window sills, furniture and playthings in the home, the straps of trolley cars, the rails, counter and desks of shops, and public buildings, and indeed upon everything that the hands of man touch." In many cases it is the germs of disease which are sown, and if the next comer has not learned that the hands are to be kept from the mouth he may easily transfer them to his mouth, and if perchance they find suitable soil the individual soon finds himself suffering with a disease. It may be a mild attack of la grippe or a fatal attack of tuberculosis. It is of ten the case in the home or the hotel that the organisms are transferred from one dish to another by the common dishcloth or dish towel.

Cell Structure.-Many bacterial cells are surrounded by a 


\section{SHAPE OF MICROÖRGANISMS}

gummy mass called the capsule. In stained cultures this appears as a halo surrounding the organisms. The presence of a great number of these capsulated organisms in milk gives to it a ropy consistency. The outer coat of the bacteria stick together so we may draw the milk out into long threads.

Surrounding the true cell is a relatively firm membrane through which the food must pass and which retains the liquid of the cell within bounds. This is the cell wall. Lining the cell wall on the

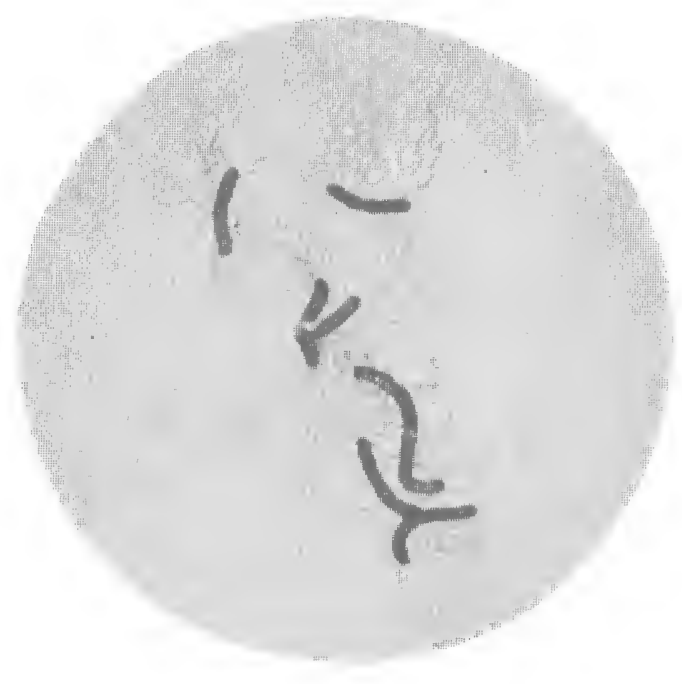

FIG. I5.-Bacteria with flagella surrounding body (after $\mathrm{McBeth}$ ).

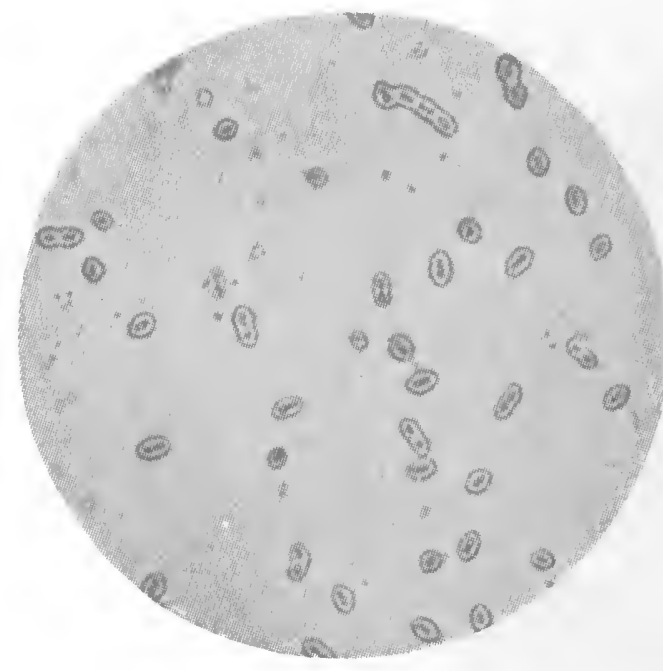

FIG. I6.-Capsulated bacteria (after Buerger).

inner side is a dense layer of protoplasm, which has a selective action on the food taken up by the cell. If the cell be placed in a strong sugar- or salt-solution the cell shrinks and the ectoplasm is torn from the cell. This is known as plasmolysis.

Within the center of the cell is a denser material which stains more deeply than the rest of the cell. This is the nucleus and functions in reproduction. It is a debated question as to whether bacteria in the strictest sense possess a nucleus. Scattered throughout the cell may be seen dark granules. These bodies, termed metachromatic granules, may react to stains in such a way as to differentiate them from the rest of the cell and give us information as to their composition. They are probably the reserve food of the cell. 
Spore Formation.-When adverse conditions arise many bacteria mobilize the vital parts of their body into much smaller space than they occupy during their normal life. They exclude all of the excess moisture and surround themselves by a tough resistant coat. In some respects this form of the organism resembles the seed of the higher plants, and we speak of it as the spore. While in this stage they will withstand many conditions which would quickly prove fatal to the growing bacteria. Some of them, while in this condition, can withstand the temperature
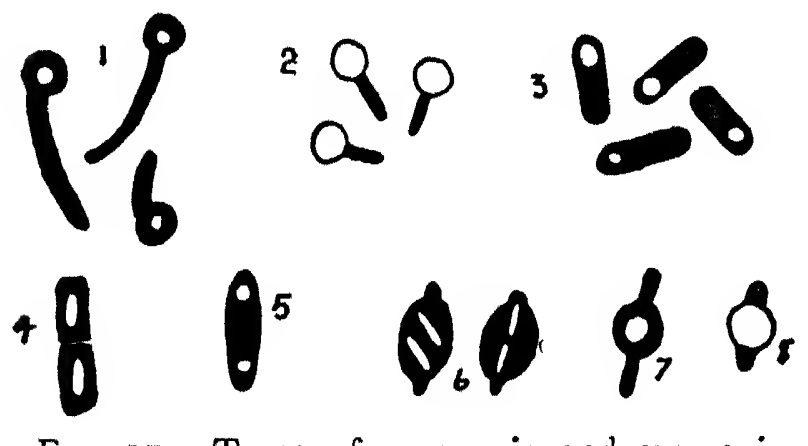

FIG. 17.-Types of sporangia and spores in bacteria. r, a spirillum with a terminal enlaiged spore. 2, bacillus with a terminal enlarged spore. 3, bacillus with terminal spore, not enlaiged. 4, bacillus with an equatorial spore, not enlarged. 5 , bacillus with two small terminal spores. 6 , bacillus with two elongate spores. 7,8 , bacilli with equatorial swollen spores, clostridia (after Buchanan). of boiling water for many hours, or they may survive $t$ he treatment with strong carbolic acid. For the time being they have lost the power of multiplying, but they are still alive, and if they are brought into appropriate surroundings they will change into normal bacteria just as does the kernel of wheat change into the young plant when placed in moist soil.

It is indeed fortunate for mankind that but few of the diseaseproducing organisms form spores. There are, however, many of the bacteria which cause fruit, meat, and various other food products to spoil, which do form very resistant spores, and this is why many food products have to be heated for such a long time or to such a high temperature to make them keep. At times, in order to avoid heating the substances to such a high temperature, the intermittent method of sterilization is made use of. In this method the substance which is to be sterilized is heated to $100^{\circ} \mathrm{C}$. for a short time. This heating kills all of the organisms which are not in the spore form. After standing in a moderately warm place for twenty-four hours, during which time the spores start 


\section{SHAPE OF MICROÖRGANISMS}

to grow, it is again heated for a short time, thus killing the others which have started to grow. Often this is repeated even a third time before the vegetable or other product is canned.

The manner of formation of the spore within the body of the organism is intensely interesting, for it varies with different species. The bacteriologist has devised means whereby he can color the body of the organism one color and the spore within the body a different color. If we stain the various organisms in the first stages of spore formation, in some we find the little red dot situated within the center of the blue body. In others it is also in the center, but is much wider than the body of the organism. Hence, we have a boat-shaped organism, clostridium. In others the spore forms at the end, and we have the drumstick-appearing organism, the capitate. This is the case with the organism causing lockjaw.

Longevity of Bacteria.-Due to their method of multiplication there is no such condition as old age among bacteria since both daughter cells are similar in age and composition. It is well known that while in the spore condition many bacteria can survive for a quarter of a century. They have been obtained from soil which has been kept under air-dry conditions in fruit jars for over fifty years. There is evidence they may live for centuries.

Morphology of Yeast.-Yeasts vary in form from a sphere to an ellipsoid. They are surrounded with quite a thick membrane in which is a colorless liquid containing vacuoles and granules. On staining they are found to possess a definitely organized nucleus. Most yeasts are considerably larger than the bacteria. Their characteristic method of multiplication is by budding. The bud appears as a small protuberance separated from the mother cell by a very narrow collar. The bud increases in size, and when it has acquired a certain size it separates from the mother cell. The daughter cell grows and soon equals that of the mother cell, after which it in turn buds. When multiplication is very active each cell may form many buds at the same time on different parts of its surface. It may happen that the buds while at- 
tached to the mother cell may begin to bud. This gives rise to a small colony of cells.

Yeasts produce spores which will tide them over adverse conditions, but they differ from bacteria in that a single yeast cell
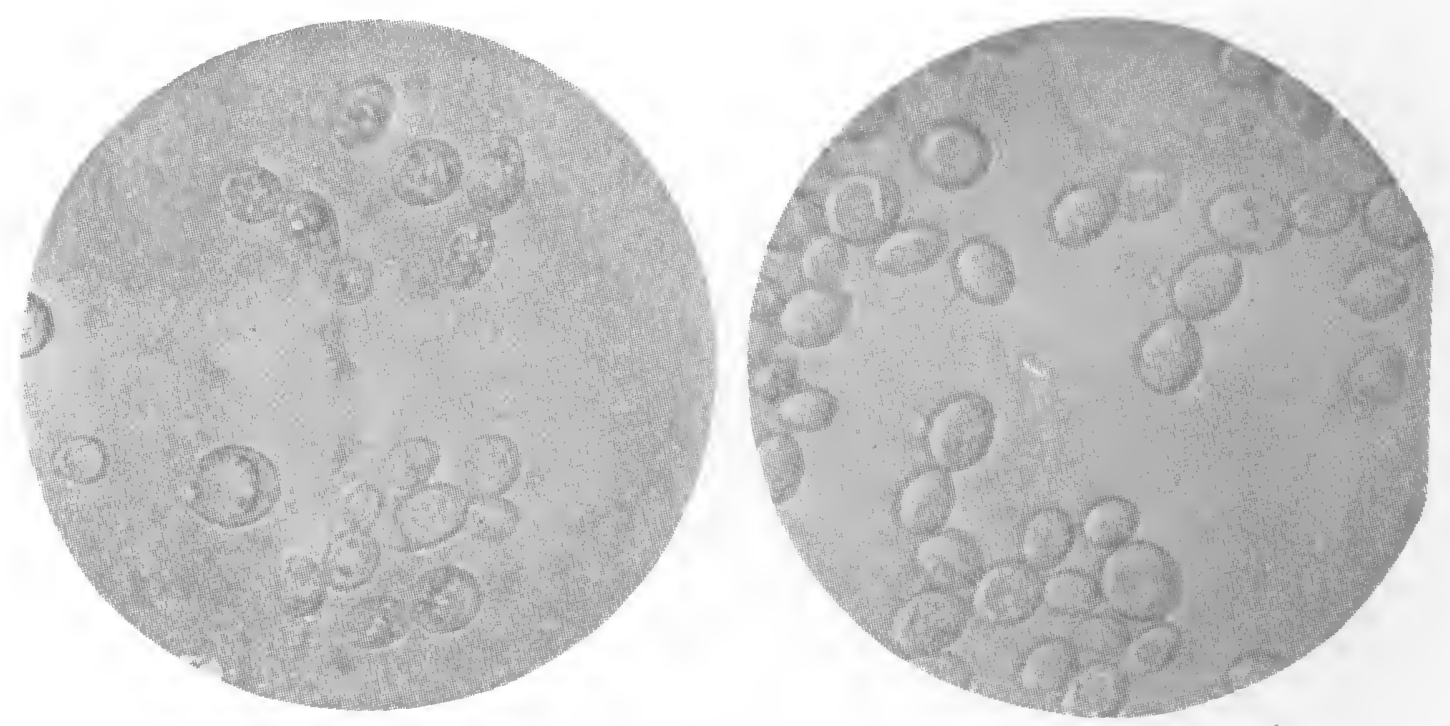

FIG. I 8.-Yeast cells (after Van Hest).

may give rise to a number of spores; hence, this becomes a process of multiplication. 'The yeasts ferment sugars with the formation of alcohol and carbon dioxid and are often classified according to the specific sugar which they ferment. Few of the yeasts produce disease in man or the lower animals. However, they

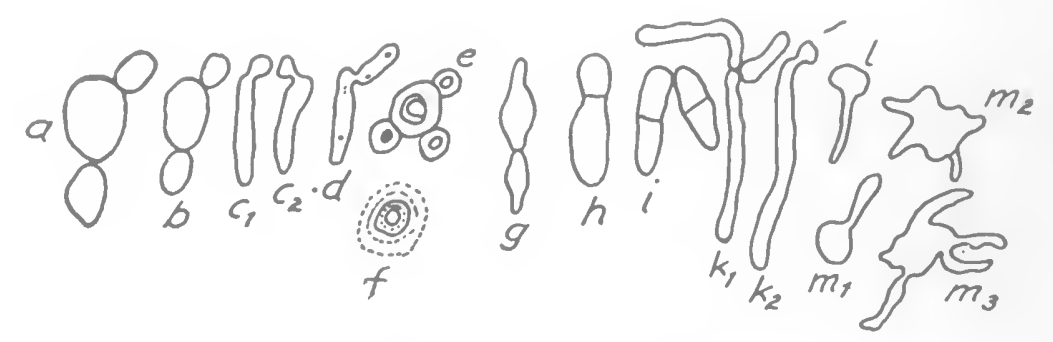

FIG. 19.--Different types of yeast cells.

have been used to combat in man certain bacterial infections as boils and carbuncles. 'Their action is probably due to the vitamin which they contain as well as to the fact that they increase the activity of the defensive substances, white corpuscles, of the body 


\section{SHAPE OF MICROÖRGANISMS}

toward the bacteria which are invading the body of the individual who is suffering with boils.

Molds. - The body of a mold is composed of numerous cells, whereas the bodies of bacteria and yeasts are single cells. The thread-like processes which compose their body are known as mycelia (singular, mycelium). The individual threads are called hyphae. In the molds there is a division of labor. Some threads serve for the taking up of nutrients and are called vegetative hyphae; the others produce spores, fertile hyphae. The cells composing the molds are similar to those of the yeasts in that they have a definite nucleus. They multiply mainly by the production of spores which are produced in the fertile hyphae above the

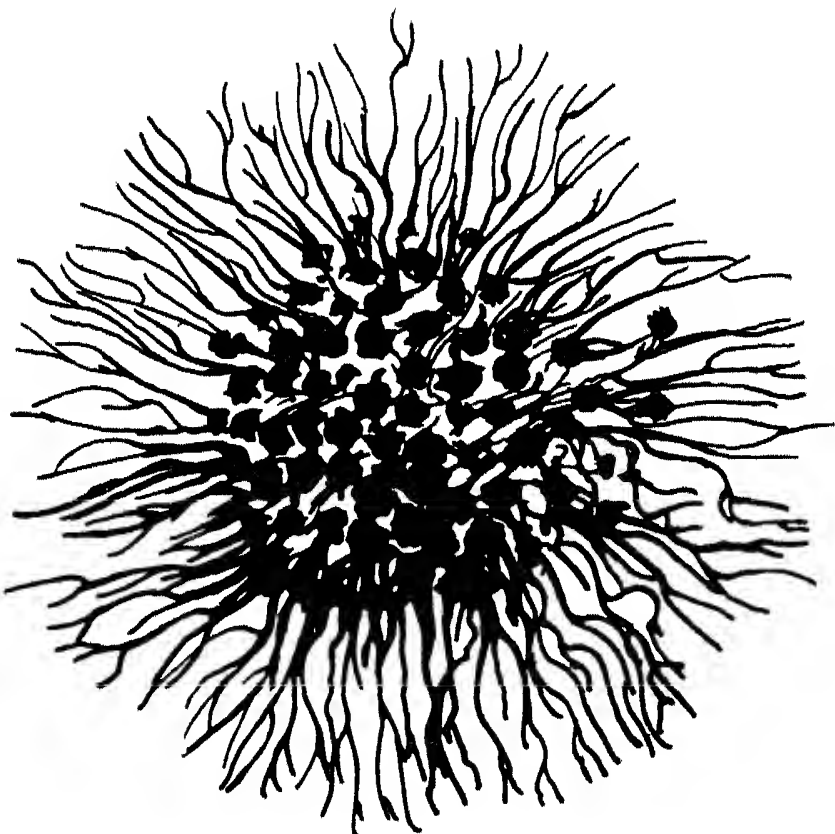

FIG. 20.-Drawing of a mold colony. surface of the medium and hence can be dislodged and spread by currents of air. They grow under conditions of acidity and moisture which are inimical to the growth of bacteria and yeasts. They differ from bacteria in that they all require free oxygen. They play a great part in the spoilage of foods and are second only to bacteria in importance in soil processes. Few are pathogenic. More of the molds than of the yeasts produce diseases in man and the lower animals. 


\section{CHAPTER IV}

\section{CLASSIFICATION OF BACTERIA}

The accomplishments of man today are little less than those attributed to the gods by the ancients. This is due to the fact that modern man accumulates information; this he organizes, and from the organized mass he draws conclusions. The conclusion, if based on sufficient information and accurately deducted, gives him a general law with which to work. Where very great masses of information or great numbers of objects are to be dealt with man must organize and classify. The librarian classifies the books of the library. The soll chemist classifies the soils of the nation or of the state. The business man classifies the materials with which he deals. Otherwise, in each case, it would be impossible to deal with the numerous complexes. Likewise, the biologist, if he is going to have anything other than chaos, must classify the plants and animals with which he works.

Method of Classification.-In classifying objects it is important to use a system in which relationships are shown. This is accomplished by arranging groups within groups. This method is familiar to all as will be seen from an example cited. An army is a definitely organized system which is composed of definitely organized units each nicely fitted into the whole. That is, an army is composed of divisions; each division in turn is made up of brigades; each brigade, of regiments; each regiment, of battalions; each battalion, of companies; each company, of platoons; and each platoon of squads. In this system each individual occupies a definite specific place in the organization. In the classification of the plant kingdom a somewhat similar organization is used. In this is recognized groups within groups. A division is composed of classes; a class is composed of orders; orders are composed of families; families are composed of tribes; tribes are composed of 
genera; and a genus is composed of species. By this system each variety of plant has a specific place within the classification. We have seen that the plant kingdom is cummonly divided into four divisions, one of which is the Thallophytes. This division is made up of classes; the classes, of orders. The orders, which comprise one of these classes, are made up of that great variety of plants which we know as bacteria. Before we consider further these orders it is best to consider the methods used in naming bacteria and the factors used in classifying them.

Nomenclature.-Early in the history of botany the worker used a descriptive phrase in referring to a species of plants. A different worker would use a different word or phrase to describe the same plant. This method resulted in confusion, for it was of ten impossible to determine whether both writers were referring to the same plant or to different plants. To overcome this difficulty the great Swedish naturalist, Linnaeus, devised the binomial system of naming plants, so-called because each species is given two names. The first is the name of the genus and the second the name of the species. The first is common to many; the second name is specific. However, it will be noted in botanical nomenclature the specific name comes last, or in other words, it is the reverse of what it is in family names. First, is given the name of the genus which must be capitalized and which may be written in full or abbreviated. This is followed by the individual or name of the species. This is written in full and with a small letter. Usage at times has sanctioned the use of a capital where the name is a proper noun. However, even here it is better to use a small letter. In order to avoid confusion and to make more clear what specific plant is referred to there is of ten placed after the name of the species the name, or an abbreviation of the name of the botonist who first used the name for the species. Following this system the name for wheat would be written Triticum sativum or T. sativum. That for the potato is written Solanum tuberosum or $S$. tuberosum. Unfortunately, this system is much less satisfactory when applied to microörganisms.

Difficulties with Bacteria-The difficulties inherent in the 
classification of bacteria are numerous. (I) The small simple structure of the microörganism makes it impossible to work out on a purely morphological basis a satisfactory classification as is the case for the higher plants. (2) Many physiological characteristics, such as pigment production, which at first sight may appear useful, are not constant and hence cannot be used. (3) Our knowledge of the characters of the bacteria even at the present time is far from complete. (4) Bacteria play a part in many fields of activity, and hence the criteria whereby they are recognized vary greatly according to the art or science in which they are studied. For agricultural and industrial purposes it may be more practical and quite sufficient to classify bacteria according to their activity. For example, we may classify them as butyric- or lactic- acid-producing, ammonifying, nitrifying, or nitrogen-fixing organisms. (5) There has been a great tendency for many authors to apply whole descriptions to microörganisms instead of using the binomial names as agreed to in botany. For instance, the following cumbersome unscientific designation has been used: Micrococcus acidi paralactici liquefaciens Halensis or Granulobacillus saccharobutyricus immobilis liquefaciens.

Migula's Classification of Bacteria.-Numerous attempts have been made to classify bacteria, but none are without flaws. One of the most extensive used throughout America is the one proposed about twenty-five years ago by Migula. Migula makes use of morphology grouping of cell due to method of multiplication and motility. The classification as modified by Russell and Hastings is given below:

Suborder I. Haplobacteria. Bacterial cells not permanently united into filaments without sheaths

Family I. Coccaceae. Cells spherical, at least when free

r. Cells non-motile

$A$. Cell division in one plane, cells frequently remaining attached in chains . . . . . . . . Streptococcus

$B$. Cell division in two planes (sometimes irregular), resulting in formation of flat plates or of masses of cells . . Micrococcus

C. Cell division in three planes, all at right angles, the cells remaining united after division, forming cubes or packets ... Sarcina 
2. Cells motile

A. Same as Micrococcus, but with flagella . . . . Planococcus

B. Same as Sarcina, but flagella . . . . . . . . Planosarcina

Family II. Bacteriaceae. Cells cylindrical in shape, not bent

I. Cells non-motile . . . . . . . . . . . . . Bacterium

2. Cells motile .. . . . . . . . . . . . . Pseudomonas

3. Cells with peritrichous flagella . . . . . . . . Bacillus

Family III. Spirillaceae. Cells elongated and bent, usually spirals or segments of spirals

I. Cells non-motile . . . . . . . . . . . Spirosoma

2. Cells motile

A. Cells, short, comma-shaped, one to three polar flagella

Microspira

B. Cells longer, with tufts of polar fiagella . . . . . . Spirillum

C. Cells very long and slender, flexible, flagella (if present) demonstrated only with difficulty . . . . . . . Spirochaeta

Suborder II. Trichobacteria.

Family Chlamydobacteriaceae. Cells cylindrical, united in threads or filaments surrounded by a sheath

A. Filaments unbranched . . . . . . . . . . . . . Leptothrix

B. Filaments showing false branching . . . . . . . . Cladothrix

C. Filaments showing true branching

(I) Spores produced . . . . . . . . . . . Nocardia

(2) No spores observed . . . . . . . . . . Actinomyces

This classification is especially unsatisfactory to the student of soil bacteriology as there is no appropriate place within it for many of the soil bacteria. Moreover, the small number of genera makes it necessary to class together organisms which are similar in morphology but which are far different in action. This is overcome in a new classification suggested by a committee of the Society of American Bacteriologists.*

Classification of Society of American Bacteriologists.The outline of this classification, as condensed by Macy, is given on the following page.

\footnotetext{
* Those desiring a more complete statement of this classification will find it complete in Journal of Bacteriology, Vol. 5, No. 3 (May, 1920), pp. 191-215, or in "General Systematic Bacteriology" by Buchanan (1924), published by Williams \& Wilkins, Baltimore.
} 


\section{CLASS}

\section{SCHIZOMYCETES}

Order Family $\quad$ Tribe $\quad$ Genus

Myxobacteriales

Thiobacteriales

Chlamydobacteriales

Actinomycetales $\left\{\begin{array}{l}\text { Actinomycetacea } \\ \text { Mycobacteriaceae }\end{array}\right.$

Actinobacillus

Leptotrichia

Actinomyces

Erysipelothrix

Mycobacterium

Corynebacterium

Fusiformis

Pfeifferella

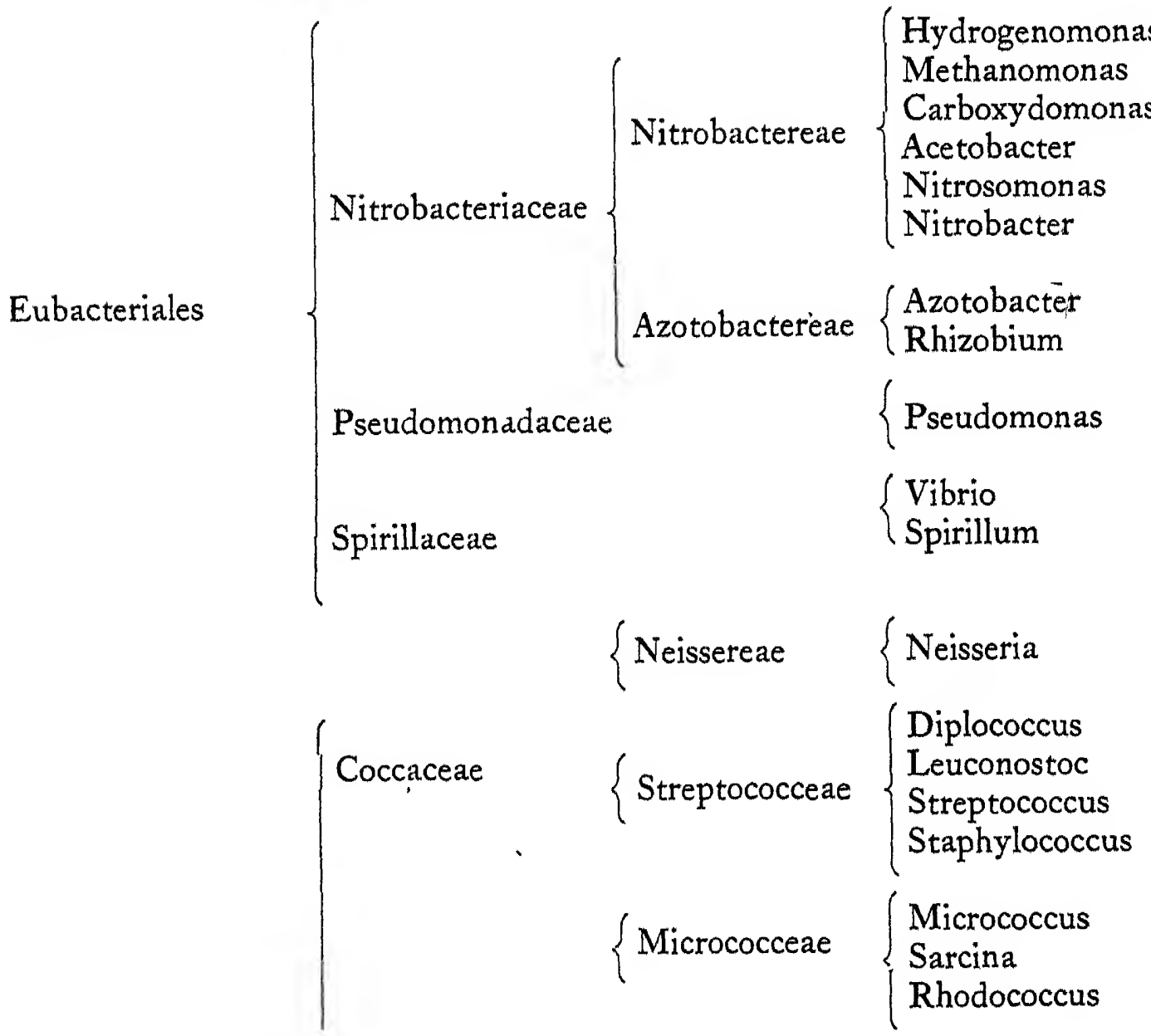


Schizomycetes (Concluded)

Order
Eubacteriales

Family
Tribe

Genus

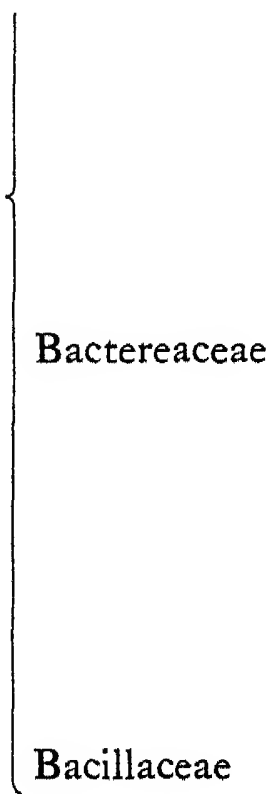

$$
\begin{gathered}
\begin{array}{c}
\text { Chromobac- } \\
\text { tereae }
\end{array} \\
\text { Chromobacteriu }
\end{gathered}
$$

Erwineae $\quad$ Erwinia

Zopfeae $\quad$ Zopfius

Bactereae $\quad$ Proteus

Bacterium

Lactobacilleae $\{$ Lactobacillus

Pasteurelleae $\{$ Pasteurella

Hemophilaeae $\{$ Hemophilus

Bacillus

Clostridium

In this the following orders, families, tribes, and genera are of especial interest to the student of soil bacteriology:

Family Nitrobacteriaceae. Secure growth energy by direct oxidation of carbon, hydrogen, or nitrogen, or of simple compounds of these. Usually water or earth forms.

Tribe I. Nitrobactereae. Energy from carbon or nitrogen

Genus I. Oxidize hydrogen for energy . . . . . . . Hydrogenomonas Genus 2. Oxidize methane for energy . . . . . . . . Methanomonas Genus 3. Oxidize carbon monoxide for energy . . . Carboxydomonas Genus 4. Oxidize alcohol for energy . . . . . . . . . . Acetobacter Genus 5. Oxidize ammonia to nitrites . . . . . . Nitrosomonas Genus 6. Oxidize nitrites to nitrates . . . . . . . Nitrobacter

Tribe 2. Azotobactereae.

Genus I. Live free, fix nitrogen . . . . . . . . . Azotobacter Genus 2. Live in symbiosis with legume, fix nitrogen . . . Rhizobium 


\section{CHAPTER V}

\section{THE CHEMISTRY OF BACTERIA}

History teaches that it is the microbe and not the bullet which digs the soldier's grave. Man slew his millions, but tuberculosis, pneumonia, and influenza slew their tens of millions during the great World War. The farmer with all his tools for tillage changes only the physical nature of his soil, but the microbe changes its actual chemical composition. What is the chemistry of this bit of protoplasm which we must magnify hundreds of times before we can see it yet which accomplishes such gigantic tasks? Shall we search within it for the wonderful radium? Or is the bacterial body even more mysterious than radium? Bacteria are plants, and plants consist of water, carbohydrates, fats, proteins, and ash. It is a plant which produces strychnin. Are similar substances found in the microbes? The needles of the pine are green; the leaves of the maple are green, yellow, or golden. Do bacteria also produce pigments? If so, what is their color and what are their functions? Let us see.

How Bacteria Are Studied.-The separation of a mixture of alfalfa, white clover, sweet clover, and crimson clover seed may present an insurmountable difficulty to the novice. But let him sow this mixture thinly on a fertile soil; the mature resulting plants are easily distinguished the one from the other. The seed could easily be collected from separate plants and accurately labeled. The same is true of bacteria. The task of picking out individual bacteria from a mixture would be too great for even the trained worker, but sow them thinly in an appropriate soil and the tiny groups which spring from the individual seeds are so distinct that even the untrained eye instantly recognizes a difference. The soil on which bacteria are sown is called a cultural medium (plural, cultural media). Different cultural media are 
required for the growth of different bacteria just as various higher plants require different soils. Most bacteria grow well in beef tea. However, we must prevent the organisms from swimming about and thus mixing during growth. This is accomplished by adding to the medium one per cent of a seaweed, agaragar. Such a medium is placed in large flasks, in test tubes stoppered with cotton plugs, or shallow dishes covered with a second

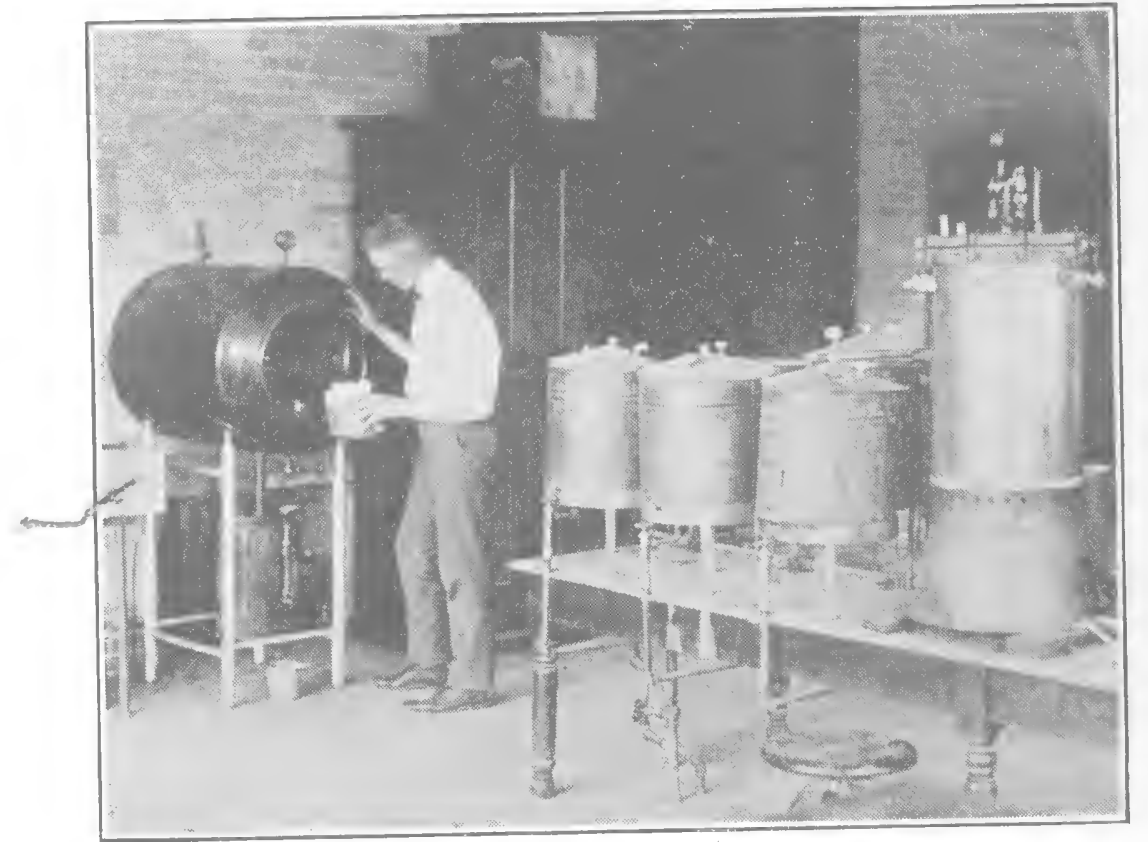

FIG. 21.-Sterilizers used in bacteriology.

dish. These are known as petri dishes. The medium is sterilized by heating in steam under pressure to a termperature of $120^{\circ} \mathrm{C}$. for fifteen minutes or at a lower temperature for a longer time. Such a medium melts at $98^{\circ} \mathrm{C}$. and does not solidify until the temperature drops to $30^{\circ} \mathrm{C}$. Hence, such a mixture, while at $40^{\circ} \mathrm{C}$. can be seeded with a few bacteria, thoroughly shaken, and poured into sterile petri dishes. When it solidifies the bacteria are anchored in isolated spots. These grow and become visible to the naked eye.

We are thus using in another field a project which has been urged with a good deal of persistency by various individuals in the past for finding out whether there were inhabitants upon Mars and perchance be able to communicate with them. 
It was suggested to build a huge outline on some great plain on the earth's surface-possibly on one of the deserts. This gigantic structure was to have some simple suggestive form as a circle, a triangle, a "T", or an " $\mathrm{H}$ ". The inhabitants seeing this would understand, and by a similar contrivance signal back to the earth. Such methods have never been used to communicate with other

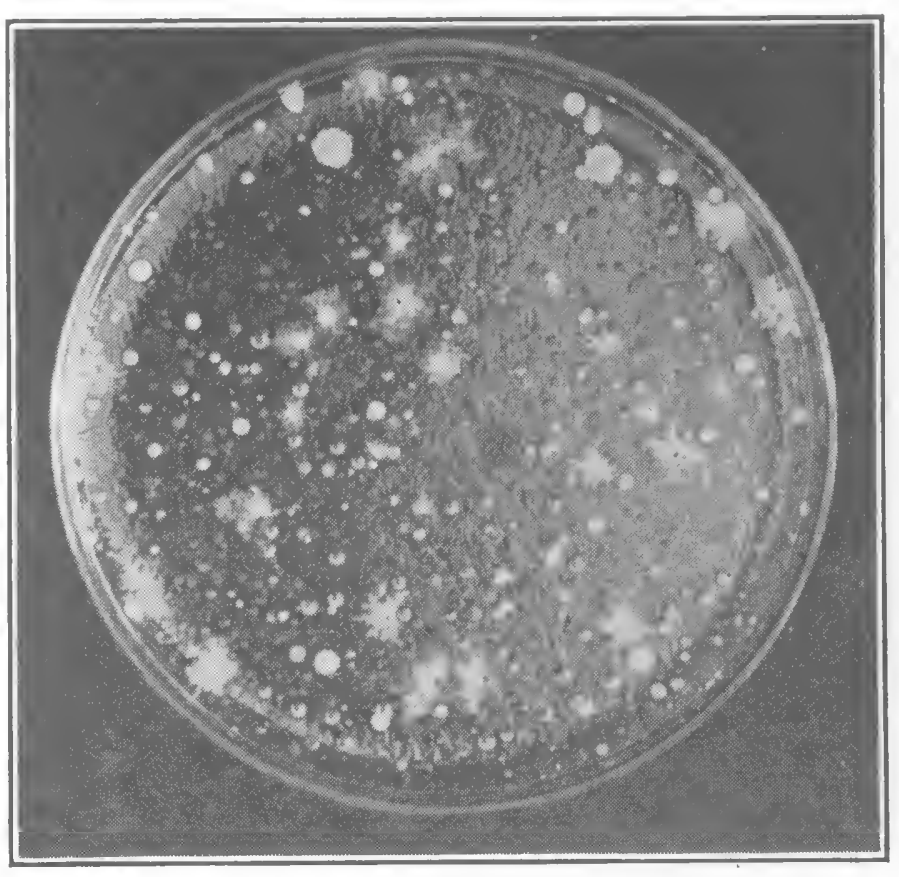

FIG. 22.-Colonies of bacteria on agar-agar cultural media. worlds. But by similar means we have made the inhabitants of the infinitely small communicate to us the secrets of their hidden life.

The $\mathrm{sh}$ a p e and structure of these colonies differ as widely as do the plants of the a $1 \mathrm{f} \mathrm{alf} \mathrm{a} \mathrm{and}$ clover. Hence, they can be distinguished one from the other. Moreover, isolated colonies can be seeded into other media, and in this way we can obtain pure cultures. By growing massive cultures in large flasks we can obtain sufficient to analyze. Or if we wish to analyze a single cell we place on it a specific dye and examine it under the microscope. If it contains fat, that part of the body is stained red. Another dye is added, and if starch be present it will be blue. If another part turns black when dye is added it contains sulfur, and so on until we have learned all the substances which compose its minute body. Such methods reveal the fact that bacteria are composed of water, carbohydrates, fats, protein, and ash.

Water.-Next to living matter water is the most wonderful thing in the world. The ancients recognized this, and Thales 
founded his philosophy and science on the idea that water is the origin of all things. Their elements were earth, air, fire, and water. "It is little short of astounding that living matter, with all its wonderful properties of growth, movement, memory, intelligence, devotion, suffering, and happiness should be composed to the extent of from 70 to 90 per cent of nothing more complex or mysterious than water. Such a fact as this is most perplexing, especially when all experiments show that this water is playing a profoundly important part in the generation of the vital phenomena. Any interference with the amount normally present makes a change at once in the activities of the cell. In fact we might say that all living matter lives in water. For not only is this obviously true in the lower and simpler forms of animals and plants, which are little more than naked masses of protoplasm living in water, but it is no less true of the higher forms since in all of them an internal medium, or environment, of a liquid nature, the lymph, the blood or sap, is found which is the immediate environment of the cells. Water is the largest and one of the most important constituents of living matter, and if organisms are carefully examined the most various devices are found to assure the regulation of the water content of the cell of the body."

Bacteria consist largely of water. The quantity present in the actively growing bacteria varies from 70 to 90 per cent. The younger the culture the more active the organism and the greater the quantity of water present. Old cultures contain less and when spores form, the water content is greatly reduced. If the water is completely removed, death results. Hence, the minute influenza organism which took more lives in two years than did man with all his powerful engines of destruction in four, is composed of 90 per cent water!

Solids.-Solids comprise the Io to 30 per cent of the bacterial cell which remains after the water has been driven off. This can be divided into organic constituents and ash. The organic part is composed of proteins, carbohydrates, and fats. Of these protein is most abundant. In this respect bacteria are similar to animals. The proteins, however, which are present are quite typical plant 
proteins. If these be broken down into their specific blocks they yield nearly the same as do the higher plants. Many of these are what we term complex or nucleoproteins. These proteins are peculiar in that they contain large quantities of phosphoric acid. Some of the bacterial proteins are extremely violent poisons and are called toxins.

The fat content of bacteria varies greatly with different species. Some, as for instance the tubercle bacilli, contain considerable fat. An interesting characteristic of such organisms is that they are extremely hard to color, but if they are once stained (as by boiling them in a strong stain) they retain the color tenaciously. Not even dilute acids or alcohol will remove it. Hence, their name, the "acid-fast organisms."

Many of the common fats, such as those of beef, cotton seed, and the olive, have been identified in the bacterial body. The cells of the tubercle bacilli have been found to contain 26.5 per cent of fat and wax in their dried substance. The nitrogen-fixing organisms which live in the soil frequently store up considerable quantities of fat in their cells.

Carbohydrates are found in large quantities in the higher plants, but in the case of bacteria they are conspicuous by their absence. A few varieties of bacteria have been found with small quantities of cellulose (woody fiber), starch, glycogen (animal starch), and some of the sugars.

The quantity of ash in the bacterial cell is considerable higher than it is in other plants. The same substances are found in both. At times nearly three-fourths of the total ash is phosphoric acid. The remainder of the ash is composed mainly of potassium, calcium, magnesium, iron, and sulfur.

Variation in Composition of Different Parts of the Cell.The worker in bacteriology not only analyzes the individual cells, but he determines the composition of different parts of the cell. This is done by using various stains as previously suggested. The outer coating of the cell, the capsule, is a sticky gum-like mass which often causes the organisms to adhere together. When they get into flour or yeast we have a bread which can be strung out 
into fine threads. This capsule consists mainly of a protein, mucin, similar to that found in the saliva. Sometimes, as in the case of the iron bacteria, they are surrounded with a sheath in which are large quantities of iron. Often such organisms are found in water. When the water is first drawn from the well it is normal in color, but, on standing, the iron in the sheath rusts and is oxidized, and we have a yellow water. These organisms are without significance from a sanitary viewpoint, but at times they form in large masses and clog the pipes. The rather tough bacterial wall consists of a compound, chitin, about midway between proteins and carbohydrates.

The inner part of the cell is composed largely of bacterial proteins which vary widely with different species of bacteria. Many of them are highly poisonous.

Toxins.-Poisonous protein substances may result from bacteria in two ways. First, the bacterial body may break down with the formation of poisonous products. Second, the bacteria may actually manufacture toxic products. To this second class of poisons is given the name, toxins. Toxins have certain characteristics which differentiate them from other poisons.

I. Toxins are specific, that is, the diphtheria organism produces a poison which if placed in the body of a susceptible animal will give rise to diphtheria. We can grow the diphtheria bacteria in beef tea and remove the bacteria; this beef tea will then cause the disease, diphtheria. Diphtheria organisms alone produce diphtheria toxin; the lockjaw organisms produce lockjaw, etc. Hence, toxins are specific.

2. Toxins are extremely violently poison, far surpassing any other known poison in this respect.

Smallest quantity of atropin required to kill man . . . . . . I30 mg. Smallest quantity of strychnin required to kill man . . . 30-40 mg. Smallest quantity of cobra venom required to kill man . . $4.4 \mathrm{mg}$. Smallest quantity of tetanus toxin required to kill man less than $0.23 \mathrm{mg}$.

The tetanus toxin is produced by the germ which causes lockjaw. The poison has never been obtained pure, yet the crude material 
is so highly fatal. What a minute quantity of the pure compound would be required to kill a man! Experiments show that only a few molecules of the botulinus poison, a poison sometımes found in food, is required to kill small animals.

3. Bacterial toxin if used in extremely small but increasing doses will produce immunity. When a very minute trace of the toxin gets into the body of an animal the cells commence to manufacture an emergency material which robs the toxin of its power. It is known as antitoxin, and the presence of this antitoxin in the blood of the individual means that he will not take lockjaw, diphtheria, or whatever the specific disease. We then say he is immune. The immunity may become so great that it makes no difference how many of these poisonous darts are shot at the individual by the microbe, they fall without piercing his armor of immunity. However, it is different with strychnin. To this the individual never becomes resistant. Man may become so he can tolerate more nicotine, but give even the habitual tobacco user a large dose of nicotine and it will kill him.

4. Toxins have an incubation period, whereas most ordinary poisons have not. If an animal receives strychnin it soon becomes ill and quickly recovers or else dies. Whereas, if an animal is given a bacterial toxin there may be a delay of days or even weeks before the symptoms appear. The time between the entrance of a toxin into the body and the appearance of symptoms is known as the incubation period. It varies with different toxins and also with the quantity of toxin administered.

5. Toxins are easily destroyed by drying, sunlight, heat, and certain chemicals. Hence, any material containing bacterial toxin, if heated throuout to $100^{\circ} \mathrm{C}$. for fifteen minutes, will be free from it. However, if strychnin had been in the substance this would not be the case. A toxin may be heated and thus lose its power of poisoning an animal but still retain its power of calling out "antitoxin," thus rendering the animal immune to the disease. This is made use of very extensively in medicine to protect us against disease.

Ptomaines.-These are products formed when bacteria break 
down proteins. They are poisonous but not nearly to such a degree as are toxins. They have none of the other properties which have been pointed out above as possessed by toxins.

Enzymes.-These are the tools with which bacteria do their work. With them they break down the carbohydrates, fats, and proteins. They also use them in the coagulation of milk and probably most other changes which the microbes bring about. Specific enzymes are used for specific purposes. For this reason they have been likened unto a key. A key will open a door, provided there is similarity between the key and lock; otherwise, it will not. It is the same with the enzyme. If an enzyme which has a certain shape is used it will unlock the sugar molecule, and we obtain alcohol. It is these enzymes with which bacteria digest their food; hence, if they have one enzyme they can break down this food-if another, that. So we may say that the enzyme determines the appetite of the microbe. What peculiar appetities microbes sometimes have! Some digest horn, others wood, and still others rock.

A peculiar property of the enzyme is its great activity. A very minute quantity can bring about tremendous changes. A thimbleful of the one which digests proteins could break down a carload of protein, provided it were given the time. If we double the quantity of enzyme we reduce the time by one-half. The reason for this is that each particle of enzyme repeats the same kind of work over and over. It is somewhat similar to the carrying of bricks from the ground to the top of a building by men. Give one man sufficient time and he would be able to transfer the whole pile to the top as would a group of men, but in the latter case the time required to carry the bricks to the top would decrease as the number of men increased. Some times, however, the time used in the work is not directly proportionate to the number of men starting. A brick may slip, catch one on the head, and he is through carrying bricks at least for the time being. A similar phenomenon occurs with the enzymes. Some of them may get entangled in some side issues, and their work is at an end. Moreover, the speed with which an enzyme works depends upon the 
temperature. Increase of temperature up to a certain point means an increase in their activities. Above this they decrease, and if the tempertaure becomes too high the enzyme is destroyed. Like animals, they are destroyed by poisons. During the life of the bacteria these enzymes are working in harmony, each performing its allotted task-some building up this part of their home, the cell, others preparing the fuel, and still others doing away with waste products. Just the minute life ceases, each enzyme commences to work independent of all others, and in time their home, the cell, is torn to pieces. This is likened unto a dance. As long as the music continues all are in step and there is a certain beautiful rhythm in all. When the music ceases, however, the dancers lose step, bump into each other, and if they continue all becomes confusion. The enzymes are the dancers in the living cell; life is the master musician who furnishes the music. Hence, enzymes manifest themselves in the living and are subject to the limitations of life in a degree, but they are not life.

Pigments.-All have heard of the miracle of the bleeding host. The consecrated bread left over night in the moist bacterial laden air of the chapel appears on the morrow besprinkled with bright red drops. What could it be? Blood! From whence did it come and what did it indicate? Various were the interpretations placed upon it, and numerous the lives and homes which were sacrified through this delusion.

The mystery, romance, and tragedy disappears when one sees a tiny organism, Bacillus prodigiosus, in the laboratory growing in tubes of starchy food and producing a blood-red pigment. Sometimes today bread becomes infected with this organism, and dough which has been set aside over night has been found in the morning to fairly rival in color that of the autumn sunset.

At times milk on standing develops a very uncanny blue color, which spreads through the dairy like an epidemic. The little culprit which has played this trick is the Bacillus pyocyaneus.

In the soil are nitrogen-fixing bacteria which form a golden yellow pigment, while others form a chocolate brown. Some in water produce green and various other colored pigments. Thus 
we have organisms which produce all the colors of the rainbow.

The phenomenon of pigment production has long attracted the attention of the scientist and many attempts have been made to explain its function, but so far none of the explanations would seem to be wholly satisfactory. The color seems to be of no material advantage to the bacteria, for colorless strains may be cultivated which possess all of the properties of the original strain with the exception of pigment production. There is no evidence that they protect the organism against light, nor is there anything that would lead us to believe that they are similar to the hemoglobin of the blood or the chlorophyll of the green plants. The best evidence, therefore, points to the conclusion that they are mere by-products which have no particular meaning to the organism.

Light.-Most individuals have been mystified and delighted, if not frightened, by the uncanny beautiful light which at times covers a stump in the forest. At times, especially along the seashore, it seems to be emitted as a mysterious yet beautiful phosphorescence from the sand. One writer tells of a cluster of sausages brought to his laboratory. It was hung in a dark cellar and when the maid went for it in the morning there "hung in the place of the sausage a fiery effigy which seemed to her more like the quondam spirits of their mysterious ingredients than the unctuous homely friend of the homeless boarder."

The explanation of these apparent mysteries is that certain bacteria live on decaying wood, leaves, salt water, meat, and fish, and emit a light. Pure cultures of these peculiar bacteria have been grown in test tubes placed alongside a watch and photographed by their own light, the light being bright enough for one to see the hour and minute hands of the watch. The mystery today is-what is the fuel that burns in these tiny lanterns and how can they so economically produce from it light?

Heat.-Probably all bacteria liberate heat, and there are a number which liberate it in sufficient quantity to change the temperature of the medium in which they grow. This is observed in the heating of fermenting silage, manure, and hay. At times the 
temperature is raised to the kindling point with the result that spontaneous combustion may occur in hay and grain stacks. Bacteria generate considerable of the heat, but other chemical processes are also active. This is made use of in the building of cold frames. A heavy dressing of fresh horse manure is placed under the top soil. This decomposes and furnishes sufficient heat to force the plants. 


\section{CHAPTER VI}

\section{FOOD REQUIREMENTS OF BACTERIA}

What do the tiny microbes feed upon? Is it possible that the good Samaritan and outlaw in bacterial society feed upon the same food? If so, one builds from it magnificent dynamos of usefulness; the other, tiny yet powerful engines of destruction. Man's food consists of proteins, carbohydrates, fats, vitamins, ash, and water: that of wheat, water, carbon dioxid, and ash. Some bacteria are like man, others are like the wheat in their food requirements. Out of the eighty known elements only ten are necessary for bacteria; three of these are gases-hydrogen, nitrogen, and oxygen; four are metals-potassium, calcium, magnesium, and iron. Three are non-metallic solids-carbon, sulfur, and phosphorus. Three of these compose the bulk of the bacterial body; some of the others are needed only in small quantities. Nevertheless, each is essential, and the growth of the cell is limited by the one present in least concentration as compared with the organism's requirements. This is a universal law, holding for all living cells. The great difference is in the form in which the various elements are required by the different plants and animals. Man needs his carbon as fats, starches, or sugars. Higher plants require it as carbon dioxid, whereas some bacteria will utilize it as horn, wood, or even coal.

How Bacteria Feed.-Man takes his food into the stomach and pours out upon it the digestive juices. These render it soluble and change it into substances which the body can use. It then diffuses into the blood and is carried to all parts of the body. Bacteria have no stomachs; hence, they pour their digestive juices into the medium in which they are living. These digest the food which diffuses into the body. Incidentally, the higher plants seize upon the digested food and use it for the building of their 
tissue. This is one of the reasons why bacteria are of such great importance in nature.

Why Bacteria Need Food.-Man requires food for two reasons: (I) For the repairing of old tissue and the building of new, and (2) for the furnishing of energy. The energy may be used to perform work, to keep the body warm, or to build complex compounds from simple ones. Both the building material and energy are obtained from the food eaten by the animal. Plants also require building material and energy. The first they obtain from the air and soil, the second from the sunlight. The energy of the sunlight they lock up in the sugar, starch, and protein which compose their bodies, from which bacteria and animals get their energy. Hence, we find bacteria require food for two purposes - the construction of the cell and energy. The energy sometimes appears, as we saw in the last chapter, as heat, light, or even electricity. However, the greater quantity of energy which they obtain is used in the building of complex compounds. This invariably comes from the food consumed and not from the sunlight, as is the case with other plants. We can therefore define a food as any substance which bacteria can use in obtaining building material, or energy, for cell construction, or activity.

Food may be divided into three great classes-organic, ash, and water. The organic compounds consist mainly of carbon, hydrogen, and oxygen. They comprise the four great groups-carbohydrates, fats, proteins, and vitamins.

Quantity of Food Required.-Bacteria are like men in that the quantity of food actually needed and that used in the presence of an abundant supply is widely different. Bacteria will rapidly multiply in distilled water. At times we find millions in a gallon. They have obtained the food for building their body from the very minute impurities in the water. Other microörganisms will grow on the surface of granite, obtaining their food from the small amount brought to them by the rain water. The maximum amount of food used by bacteria is often enormous. They quickly decompose the body of an ox after death. Tons of material are carried into the septic tanks of large cities, all of which 
is rapidly used by bacteria. The speed with which they decompose material is great at first and later slows down or comes to a complete stop unless the accumulation of their by-products is prevented.

The food required by each bacterial cell for building material is not great, for it would take one billion six hundred million colon bacilli to weight approximately one milligram. The waste products and repair material would make the cellular requirements slightly higher than this, but the figures are sufficiently accurate to indicate that the actual quantity needed for building material for one cell is exceedingly small.

The quantity required for energy is greater and varies with different organisms. Those which only partly digest their food leave most of their energy in the by-product. For instance, bacteria which completely oxidize sugar to carbon dioxid will obtain thirty times as much energy from one gram of grape sugar as others will which change it only to alcohol.

Kinds of Foods Required.-Bacteria feed upon a great variety of substances. The sulfur, iron, and nitrifying bacteria are able to live upon mineral nutrients. The sulfur organisms obtain their energy through the oxidizing of sulfur dioxid to sulfuric acid. The nitrifiers oxidize ammonia to nitrites and then to nitrates. Both classes likewise obtain their building material from simple inorganc compounds. Hence, they can live without plant or animal tissue and in the absence of sunlight. Therefore, they were probably the first inhabitants of this globe. The majority of bacteria cannot live upon inorganic compounds, but like animals they require more complex foods. The ordinary decay bacteria will thrive on any plant and animal tissue. Woody fiber, bone, horn, and proteins of all kinds are rather rapidly consumed by them. Other organisms, as for instance the one causing tuberculosis, are more particular in their food requirement, growing best on blood and body extracts. Others, as for instance the leprosy organism, appear to grow only in living tissue.

Those bacteria which require neither organic carbon nor organic nitrogen, but live as do the higher plants upon the minerals, 
are often referred to as autotrophic bateria; those which feed upon dead plants and animals are called heterotrophic or saprophytes, those which feed upon living plants and animals we designate as parasites. To the first two classes belong the beneficial soil organisms, whereas the parasites are the disease producers. These are often spoken of as pathogens. A microörganism may live at one time as a parasite, at another as a saprophyte. For example, the tuberculosis organism growing in the lungs of man, cattle, or chickens is a parasite, but when growing in the test tube of the bacteriolgist it is a saprophyte. Some few bacteria appear to live only as parasites. In time even these we may learn how to grow in the test tube.

Water.-Man can live for days without food but only for hours without water. The same is true of bacteria. Remove all the water from the medium in which bacteria are growing and they soon die or pass into the spore stage. The pneumonia coccus, the cholera spirillum, and the Pfeiffer bacillus die in a few hours on drying, whereas the typhoid, diphtheria, and tuberculosis organisms may survive days. The tetanus, anthrax, and many soil bacteria resist drying for months or even years. In these latter cases the water is never completely removed; otherwise the organisms would quickly die.

Water plavs a number of parts in bacterial life. (I) It dissolves the food so it can be taken up by the bacteria. When the food is not already soluble the microbe throws off an enzyme which brings the food into solution so it may be taken up by the cell. (2) Water carries the waste products from the cell. (3) It enters into nearly all the changes going on within the cell. When starch is being digested water enters and the starch breaks into sugar. Fats break into glycerine and an acid through the taking up of water. In the digestion of proteins every step is accompanied by the taking up of water. When bacteria are building up in place of breaking down, water is the pivot around which all reactions turn. If food burns within the body or within the stove water is continually being evolved. (4) Water is the whip which speeds up all reactions. If a match becomes wet 
it will not ignite; nor will it if the air, match, and surface on which it is rubbed is absolutely dry. It is the same with the changes going on within the cell. Water must be present or the cell reactions will not proceed normally. (5) Water enters largely into the composition of the cell, as bacteria consist of from 70 to 90 per cent water. (6) Water gives to the cell its shape. If we place a cell in a strong salt solution water is drawn from it. If we place it in distilled water it bursts. The force which causes the bursting is called osmotic pressure. 'The extent of this pressure varies with different cells. It averages about the same as that of a 0.9 per cent salt solution. This is about 7.I atmospheres. In such a solution the tissues neither gain nor lose weight.

Carbon Requirements.-All bacteria require carbon. But in what queer form some microbes take their carbon! There are bacteria in the soil which utilize the poisonous carbon monoxid or inert carbon dioxid. The microbe cannot get energy but only building material from the latter. We use formaldehyde to destroy disease-producing bacteria; yet there are soil organisms which will flourish on dilute formaldehyde gas. Both the soil and manure contain bacteria which use urea. From some of it they construct their bodies, but most of it is changed into ammonia which is used by other tiny plants. The woody fiber of the plant yields its carbon to bacteria, and there are writers who claim that coal is produced by the action of bacteria upon plants. Be this as it may, Renalt describes fossil bacteria, which are found in coal, and today we know microörganisms which can get their required carbon from coal. Shall we say that of the various forms of carbon that diamond and graphite alone are free from the attack of bacteria? Most bacteria, however, require their carbon in the form of a carbohydrate. The sugars are especially accepted. The nitrogen-fixing organisms of the soil oxidize these to simple acids and gases, and with the energy thus obtained convert nitrogen into complex organic compounds. They seem to have a special preference for the three- and six-carbon sugars. There are microörganisms which will pick from a medium all of one compound leaving others very similar untouched. This peculiar property is often 
made use of by the chemist in separating nearly related compounds. Numerous bacteria utilize alcohol and one class obtains its energy from it and yields the valuable by-product, vinegar.

The carbon in the fat molecule is more resistant to the attack of bacteria. For this reason it often gives considerable trouble to the plumber. Fatty materials are thrown into the sink; they find their way into the sewer, bacteria dissolve the accompanying substances and the fat is liberated. This collects around some object, as for instance a match. As this is rolled along by the water it gathers more fat, until at times it becomes large enough to clog a pipe. Proteins yield their carbon readily and of ten in the breaking of them down, as for example in the egg, the sulfur is changed to the ill-smelling gas, hydrogen sulfide. A few of the pathogens require their carbon as the complex body tissues and fluids, and a very few at the present time seem to require that this tissue or fluid be in the body of a living animal.

Nitrogen.-Nitrogen in the free form is one of the lazy elements. However, when once cajoled into joining hands with carbon and oxygen we get our most wonderful compounds. The most beautiful dyes contain nitrogen. It is tucked away in our most powerful explosives, ready on the least provocation to become excited and blow everything to pieces. The most delicate perfumes and powerful poisons contain it. But most wonderful of all, it is the basis of living protoplasm. All microörganisms require it in one form or another. The nitrogen-gathering organisms of the soil can cause the lazy atmospheric nitrogen to join hands with carbon, hydrogen, and oxygen and thus produce their mysterious body. There are bacteria in the manure which will transform urea into ammonia. Another class of organisms oxidize the ammonia to nitrites; still others, in getting their energy, transform the, nitrites into nitrates. Many bacteria can use the nitrogen in egg, milk, flour, and all kinds of plants and animal tissue; others require a complex nitrogen compound of living plant and animal tissue. Sometimes the protein compounds are pulled to pieces with the formation of ptomains; at other times they are built into those most powerful of all poisons, 
toxins. Much of the nitrogen, however, is used in building that wonderful little engine, the body of the microbe. They break down the complex proteins into simple building blocks before they are built over into their body just as man would reduce the wall of an old church before building it over into a new schoolhouse. Soil bacteriology deals mainly with the organisms and their relationship to the nitrogen supply. Many bacteria are busy changing the nitrogen compounds into forms which are acceptable to the higher plants.

Oxygen.-Bacteria are like all other plants and animals in requiring oxygen. The various classes, however, require it in different forms. One great group of microörganisms require their oxygen as it is in the atmosphere-free. To these are given the name aerobes. Others require it in compounds as 'carbohydrates. These are known as anaerobes. Some organisms grow best in the presence of free oxygen but can become adapted to the use of combined oxygen. These are known as faculative anaerobes. Free oxygen is a poison to absolute anaerobes. True aerobes are great lovers of oxygen, and if shut up within a little cell containing a few drops of water in which is enclosed a bubble of air, on examination under the microscope it will be seen that the motile ones will make their way from all parts of this tiny ocean and be clustering around the drop of air.

Vitamins-We hear much today of the vitamin requirements of man, and it would seem that bacteria may need similar substances. The extracts of animal organs as well as those of plant tissue are valuable nutrient material for some bacteria which it is impossible to supply in any medium of known composition. These substances have been termed vitamins, or accessory growth factors. Sometimes it is only when first taken from the body of the animals that these substances are needed. The tubercle bacilli on being taken from the lungs of a man grow slowly on even blood serum, but after a time they adapt themselves to other media. On the other hand, the bacillus causing leprosy always requires the highly complex tissue for growth.

Ash Requirements.-Animals kept on a diet of pure water, 
ash-free protein, carbohydrates, and fats die sooner than if given only water. Likewise, bacteria require ash. They use it for various purposes: (I) For maintaining the osmotic pressure of the cell which gives to it its plump contour and assists in the taking up of foods. (2) For the neutralizing of acids, the nitrifying organism and many others produce acids which if left to accumulate would soon cause the death of the cell. (3) Some of the ash is built into the body of the microbe which gives to it its peculiar chemical and physical properties. Some bacteria use sulfur for energy. These comparatively large organisms when taken directly from sulfur springs have within their bodies yellow granules of sulfur, but on fasting these soon disappear, and sulfur dioxid, hydrogen sulfide, or sulfuric acid appear in their place depending on the specific microörganism which is being studied.

Mutual Relationship between Plants.-There are some species of bacteria which live in close association with other plants and in this manner get their food. The legume bacteria live in the small nodules of the alfalfa plant drawing from it the food needed and give the alfalfa in return nitrogen compounds. Such a friendly association of one organism with the other is called symbiosis. This mutual association plays a prominent part in soil bacteriology, for probably there are many bacteria which thus associate the one with the other.

Sometimes one microbe changes the food so that another can readily use it. There are bacteria in the soil which break down plant tissues into acids which are used by the nitrogen-fixing bacteria. The yeast acts on sugar and changes it to alcohol. This can be used by bacteria in producing vinegar. This association is known as metabiosis.

There are other species of bacteria which are mortal enemies and cannot live together, one species killing out the other almost as fast as they come in contact with each other. The details of this miniature warfare are not well understood, nor do we know the weapon in all cases by which it is carried on. It is probable that some poison is secreted which is without effect upon its pro- 
FOOD REQUIREMENTS OF BACTERIA 6 I

ducer but deadly to its antagonist. This is well illustrated by the following example. Meat if left by itself soon spoils, but if dropped into buttermilk will keep some time. The lactic acid formed by the milk organisms is a deadly poison to the putrefying bacteria. This antagonistic action is called antibiosis. 


\section{CHAPTER VII}

\section{FACTORS INFLUENCING BACTERIAL GROWTH}

The principal factors, in addition to food, governing the growth and development of microörganisms are temperature, light, electricity, pressure, shaking, and presence or absence of injurious substances.

These may affect bacteria in any one of several ways: (I) They may actually destroy the microörganism, thus leaving the medium sterile. (2) They may increase or decrease the rate of growth and metabolism in general. (3) They may change the products which that specific organism produces. In this way a microörganism which produces a disease in a very severe form may be so modified that it is produced in a very mild form. This is used extensively in producing artificial immunity in animals. (4) They may change the shape and structure of the organism.

Temperature.-All life is dependent upon a suitable temperature. The body of man and the higher animals possesses a complicated mechanism which maintains the body temperature nearly constant throughout life, independent of the surrounding temperature. The temperature of the body of cold-blooded animals and plants is dependent upon the temperature of their surroundings. When the temperature changes from normal, however, we may have a slowing-up of the growth process, a total cessation of growth or death, depending upon the magnitude of the change. The extent of the variation necessary to produce these changes varies with different organisms. Every organism, however, has an optimum, minimum, and maximum, growth-temperature, as well as a thermal death-point.

The optimum temperature is the one best suited to the growth of the microörganism. This varies widely with different species. Cold water and soils contain numerous bacteria, the optimum 
temperature of which is $15^{\circ} \mathrm{C}$. or even lower. In 1887 Forester isolated from phosphorescent fish light-emitting bacteria which not only lived at $0^{\circ} \mathrm{C}$. but actually reproduced at this temperature. Since then numerous organisms have been isloated from soil and salt waters which rapidly multiply at $0^{\circ} \mathrm{C}$. or slightly lower. To them has been given the name of psychrophilic or cold-loving bacteria. These are of considerable importance in soils of the northern climes and probably in the changes going on in meats and vegetables while in cold storage.

In contrast to these cold-loving bacteria are certain so-called thermophilic or heat-loving bacteria. These organisms have been repeatedly obtained from the waters of hot springs, the interior of fermenting manure and ensilage, soil, and the intestinal contents of man and animals. Some of them multiply at a temperature of from $70^{\circ}$ to $80^{\circ} \mathrm{C}$. What an interesting speck of living matter that can live and function at such a temperature! Are they similar to the host of the infernal regions? For this is near the boiling point,- - this temperature rapidly coagulates egg albumen, produces painful burns on the skin, and quickly kills most microbes.

Between the cold-loving and heat-loving species is the class which contains the overwhelming majority of microbes-the mesophilic organisms. These may be divided into two great classesthose found in the body of man and animals during health and disease which have an optimum temperature of about blood-heat $\left(37.5^{\circ}\right.$ C. $)$, and those whose optimum temperature is usually between $20^{\circ}$ and $35^{\circ} \mathrm{C}$. To this last belong all the beneficial soil organisms.

The minimum temperature is the lowest at which bacterial growth will occur. With many of the disease-producing organisms it is only two or three degres below the temperature of the body of the animal in which the microörganisms are usually found. For some heat-loving bacteria it is as high as $40^{\circ} \mathrm{C}$. and for the cold-loving as low as $0^{\circ} \mathrm{C}$. or below. The maximum temperature is the highest at which growth and multiplication can take place. This in the case of the pathogenes is only 
a few degrees above the optimum, but in the case of the saprophytes it may be many degrees above. For the heat-loving bacteria it may be as high as $89^{\circ} \mathrm{C}$., whereas for the disease producers it lies between $40^{\circ}$ and $50^{\circ} \mathrm{C}$. The growth of some disease-producing organisms at a high temperature for some time causes them to lose their disease-producing power but not their power of calling out anti-bodies. Hence, this means is sometimes used in the preparation of vaccines. Most of the psychrophilic organisms will not grow at a temperature above $30^{\circ} \mathrm{C}$.

The temperature relations for the three classes of organisms may be seen from the following table:

\begin{tabular}{|c|c|c|c|c|}
\hline \multirow{2}{*}{ Class } & \multicolumn{3}{|c|}{ Temperature $(C)$} & \multirow{2}{*}{ Where Found } \\
\hline & Minimum & Optimum & Maximum & \\
\hline $\begin{array}{l}\text { Psychrophilic Bacteria } \\
\text { (Cold-loving) }\end{array}$ & $\circ$ & $15-20$ & 30 & Water, soil \\
\hline Mesophilic Bacteria & $15-25$ & 37 & 43 & Bodies of animals \\
\hline $\begin{array}{l}\text { Thermophilic Bacteria } \\
\text { (Heat-loving) }\end{array}$ & $25-45$ & $50-55$ & 85 & $\begin{array}{l}\text { Bodies of animals, } \\
\text { manure, hot springs }\end{array}$ \\
\hline
\end{tabular}

The growth-temperature range of an organism is the number of degrees between the minimum and maximum. This is narrow for some organisms, as for instance the disease-producing organisms, and wide for many of the saprophytes.

Cold.-Although bacteria cannot function below $0^{\circ} \mathrm{C}$. yet they are extremely resistant to very low temperatures. The common bacteria of the soil and water as well as the diphtheria and typhoid bacilli have been exposed for days to the temperature of liquid air (about $-\mathrm{r} 90^{\circ}$ C.) without destroying them or sensibly changing their properties. Others have been exposed to the temperature of liquid hydrogen (about $-250^{\circ} \mathrm{C}$ ) with the same results. Freezing causes a great decrease in the number of microorganisms in water. This is probably due to the drying of the cell and also to the great pressure generated within the water on 
freezing. A very interesting condition is often found in natural ice filled with air bubbles. On examining the ice surrounding the air bubble it will be found to contain many more bacteria than does the rest of the block. And curious enough, these organisms are the oxygen-loving ones which have been attracted to this region by the air and then caught on the congealing of the water.

The bacteriologist recognizes what he calls a thermal deathpoint. This is that temperature which under given conditions will kill an organism in a given time. It is evident to all that a living organism may withstand a comparatively high temperature for a short time, whereas a much lower temperature will kill in a longer time. The time, therefore, is usually taken as ten minutes.

One can place his hand in an oven at a temperature of $130^{\circ}$ C. for a short time, whereas if placed for this same length of time in steam, the temperature of which is $100^{\circ} \mathrm{C}$., a painful burn may be the result. This is due to a number of factors: (I) Moist heat is more penetrating than is dry heat. (2) The steam on changing to water liberates large quantities of heat. (3) Death is probably due to the coagulation of the proteins which compose the bacterial body, and the temperature at which albumen coagulates varies with the quantity of water present, as may be seen from the following:

Egg albumen +50 per cent of water coagulates at
Egg albumen +25 per cent of water coagulates at $74-86^{\circ} \mathrm{C}$.
Egg albumen +18 per cent of water coagulates at $80-90^{\circ} \mathrm{C}$.
Egg albumen +6 per cent of water coagulates at $145^{\circ} \mathrm{C}$.
Egg albumen +0 per cent of water coagulates at $160-170^{\circ} \mathrm{C}$.

That is, we may heat dry egg albumen to the ignition point without causing it to coagulate. It is evident that the thermal death-point for microörganisms in water would be much lower than for the same microörganism in dry air.

The housewife cans strawberries, raspherries, plums, and other acid fruits with considerable ease, but corn and peas give considerable trouble. One is acid and the other neutral, and mi- 
crobes are destroyed more easily in an acid or alkaline solution than in a neutral one. Hence, in determining the thermal death-point of bacteria a neutral salt-solution is used.

Potatoes may be dropped into boiling water and left for one hour and still be infected with bacteria. They had on their surface resistant spore-bearing bacteria. We find, therefore, that the temperature necessary to kill also varies with the organism and the condition of the organism when heated.

When one is desirous of freeing any substance from these heatresistant organisms one of two methods is used: (I) Heating in a steam autoclave at an increased pressure for a given length of time, depending upon the substance to be sterilized. This permits the heating of the medium to a temperature above $100^{\circ} \mathrm{C}$. (2) The intermittent method of sterilization may be used. This is carried on by placing the substance to be sterilized in live steam for a definite time on one day and then setting aside in a warm place for twenty-four hours, during which time the spores germinate. Then the heating process is repeated. This is usually continued for even a third time, when the medium is usually found free from microörganisms.

Light.-The direct rays of the sun are injurious to living tissues, as every boy can testify who has spent too many hours in swimming with the sun beating upon his back. Moreover, we of ten find individuals who spend much of their time indoors and when they go on a fishing trip they often return with a blistered nose. Now bacteria are even more sensitive to light than are the cells of the human body. Diffused sunlight hinders their growth, and the direct sunlight is highly injurious. Some bacteria are killed almost instantly when exposed to the full action of the sun's rays. Hence, we find the foundation for the oftquoted Italian proverb, "Where the sun does not enter, the doctor does." Sunlight probably plays a major rôle in the sterilizing of water and the destroying of pathogenes which find their way into the air during coughing, speaking, and sneezing. All light rays are not of equal importance, the blue to violet rays being more active than the yellow to red. Therefore, the injurious effect 
is not due to heat but to the fact that the active light rays generate a poison within the cell.

Röntgen and radium rays have little effect when allowed to play directly upon bacteria. However, if the bacteria are in living human tissue they are destroyed. The electric light in time will kill bacteria, but microbes are much more resistant to this than they are to sunlight.

Electricity.-Can the little microbe be shocked to death by the electric current as can man? It would seem from the work which has been done that this is not possible. The passing of the electric current through a medium in which bacteria are growing destroys many. This is due to the heat generated and chemicals produced by the electricity passing through the medium. It is, therefore, something like it was with the individual who fell from a third-story window, and in telling of it his friend said, "It was not the fall which hurt Pat but the sudden stop."

Electricity is used quite extensively today in the sterilization of water and sewage and some have suggested its use in sterilization of milk and other food products. The expense involved precludes its extensive use at the present time.

Shaking.-When subjected to the prolonged shaking of heavy machinery bacteria are first prevented from multiplication and later killed. This may be due to the actual breaking of the cell to pieces by the violent shaking. However, it is well known that the continuous shaking of some proteins will cause them to coagulate.

Osmotic Pressure.-If a perfume is liberated in one part of the room its odor can soon be detected in any part of the room. We thus find that gases tend to diffuse from points of high concentration to points of low concentration. Similarly, if we dissolve copper sulfate in water, place it in the bottom of a tall cylinder, and cover with pure water, we shall find that as time goes by the blue zone of copper sulfate creeps up into the clear solution and in time the two solutions would be of uniform concentration. Now, the force which is driving the copper sul- 
fate from the point of high concentration to that of low is known as osmotic pressure. By appropriate means this pressure can be measured, and it is found to be dependent upon the number of particles of the substance in solution. We have found that a cell is covered by a membrane which is readily permeable to water but only slowly to salts. Furthermore, we have found that the concentration of protoplasm in this cell is about the same as a 0.9 per cent solution of common salt. A cell dropped into such a solution neither loses nor gains in weight, but if it is dropped into a more concentrated salt solution it shrinks, and a careful microscopic examination of it shows that the inner ectoplasm has been torn from the cell wall. This we call plasmolysis. The salt in the solution bathing the cell is more concentrated than that on the inside. The salt molecules cannot get out to equalize pressure; hence, the water passes in to dilute the solution. The plasmolysis of a cell may cause its death. Therefore, we find that the placing of bacteria into strong salt or sugar solutions causes their death. Advantage is taken of this in the making of jellies, syrups, and preserves. Moreover, it is one of the factors entering in alkali soil. We find that when the osmotic pressure of the soil reaches about 8 atmospheres the nitrifiers are depressed in their activities, but are not entirely stopped until the pressure reaches from 15 to 20 atmospheres. The ammonifiers are interfered with when the osmotic pressure reaches 9 atmospheres, but they are not entirely stopped until it reaches from 25 to 30 atmospheres. The nitrogen-fixing organisms are even more resistant to osmotic changes than are the ammonifiers.

Pressure.-Bacteria are extremely resistant to great pressure, as they are found at great depths in the ocean where the pressure would be tremendous. However, successful attempts have been made to preserve fruit and vegetables by exposing them to high pressure. Apple juice subjected to from 4,000 to 8,000 atmospheres' pressure for thirty minutes did not develop gas. Peaches and pears exposed to this pressure did not spoil during five years. Those vegetables on which are found resistant spores could not be preserved by such pressure. 
Poisons.-The action of poisons upon bacteria varies with the microbe, the kind of poison, and the conditions under which this poison is used. Extrcmely weak solutions of most poisons stimulate bacteria, a stronger concentration prevents growth and multiplication, whereas a still more concentrated solution may kill them.

A substance which kills bacteria is called a disinfectant; if it only prevents growth and activity it is known as an antiseptic. The application of a disinfectant as a gas is termed fumigation. When a chemical is added to a food with the idea of preventing decay it is called a preservative. In sanitation disinfectants and antiseptics are extensively used in the prevention of disease. In agriculture they are often used on plants or in the soil to destroy injurious microbes. The principles involved in both cases are similar and are subject to certain general laws.

(I) The efficiency of a disinfectant varies with moisture. A dry poison has but slight action upon bacteria. Dry formaldehyde, or sulfur dioxid, is practically without effect. In a similar manner absolute alcohol has not nearly the germicidal power of 60 to 70 per cent alcohol. This is probably due to the absolute alcohol coagulating the outer membrane of the organism and thus preventing the poison from diffusing into the vital part.

(2) The temperature of the medium in which the organisms are present affects materially the action of the disinfectant. A 5 per cent solution of common soda at normal temperature may have but little germicidal influence, but raise the temperature of the medium in which it is placed to $40^{\circ} \mathrm{C}$. and it becomes quite effective.

(3) Bacteria are more easily killed by a disinfectant in pure water than in saliva, blood, or other body fluids.

(4) Emulsions usually have greater germicidal effects than have true solutions. This is due to the emulsion having little globules of the concentrated poison distributed throughout the solution, and if examined under the microscope these, together with the suspended bacteria, will be seen moving about in the 
solution. When the bacteria get into one of these highly concentrated drops of poison they are quickly killed.

(5) The disinfectants of the heavy metal group must be in solution so as to form ions of the metal which can combine with the protein of the bacterial cell and thus cause death.

(6) Bacteria may withstand the action of a strong poison for a short time, whereas a weaker solution active for a longer time will cause death.

Some of the more extensively used disinfectants are quicklime, bleaching powder, sulfur dioxid, formaldehyde, and mercuric chloride. That extremely violent poison, hydrocyanic acid, of which a Freshman once said, "It is so poisonous that a drop placed upon the tongue of a dog will kill a man," is a very poor disinfectant, but it quickly kills all insects.

Chemotaxis.-It has been repeatedly shown that bacteria, like other free-moving organisms, are attracted by certain chemical substances in solution (positive chemotaxis), and repelled by others (negative chemotaxis).

A very simple and efficient method of studying this in bacteria is as follows: A capillary tube, sealed at one end and from 5 to $10 \mathrm{~mm}$. in length, is filled with a 5 per cent slightly alkaline solution of beef tea or peptone. The outer surface of the glass is carefully cleaned from any trace of the beef tea and is placed in a drop of water containing bacteria. In a few seconds the bacteria are found to thickly congregate around the open end of the tube. This is not due to any volition on the part of the bacteria, nor is it due to their congregating in places most favorable for life, for had the capillary tube been filled with sugar or glycerine, which are excellent food-stuffs, there would have been no such gathering of the bacteria at the end of the tube. Moreover, a dilute solution of potassium chloride and mercuric chloride attracts bacteria, but they rush into the tube only to meet their death. Some say that bacteria are attracted to the roots of the alfalfa in the soil by some such means, and it is quite certain that the white corpuscles are attracted to an infected wound by this means. 


\section{CHAPTER VIII}

\section{SOIL FORMATION}

Soils are the earthy material in which plants have their anchorage and from which they obtain their water and part of their food. They are in reality disintegrated rock intimately mixed with varying quantities of decaying plant and animal residues. They are derived from the native rocks by the complex process known as weathering. The agents at work in this process are physical, chemical, and biological. The work of the physical agencies is disintegration and consists in the changing of the ultimate size of the particles which constitute the surface of the earth. The chemical and biological agencies produce new compounds. Sometimes they are more simple, sometimes more complex. It is "as where an entire building is razed to the ground and another of quite different architectural features is constructed from the old materials; or again, where, without change of general plan, old timbers are here and there replaced by new; so here we have at work a series of processes in part seemingly destructive and part constructive, but all tending toward one end.

"The firm and everlasting hills we must learn to regard as neither firm nor everlasting. Whole mountain chains of the geological yesterdays have disappeared from view, and as with the ancient cities of the East, we read their histories only in the ruins. Yet, in all this seemingly destructive process of breaking down, decomposition, and erosion, there is traceable the one underlying principle of transformation from the unstable toward that which is today more stable. Nothing is lost or wasted. It is a change which began with the beginning of matter; which will end only with the blotting out of matter itself. There are no traces of a beginning, there is no prospect of an end." 
PHYSICAL AGENCIES

Temperature Changes.-Probably the greatest single factor in rock disintegration is change in temperature, for by it rocks weighing tons are torn from their mooring and then broken into fragments. It is a well-known fact that most substances expand when heated and contract when cooled. It is less well known that the extent of this expansion varies with different substances. Marble expands more on heating than does granite, and sandstone still more than either. Now, most rocks are composed of a number of different minerals. These when heated expand and contract unequally, thus putting parts under a strain which at times cause cracks of varying size. Even substances of uniform composition if quickly heated and cooled often break. This principle is made use of by the farmer who builds a fire upon a large bowlder and later pours cold water upon it. Extremes of many degrees in temperature may occur in some places within a few hours.

During the day the rock becomes so highly heated as to be uncomfortable to the touch, while at night the temperature sinks nearly to the freezing point. In regions of such great extremes of daily temperature the splitting of pieces from the parent ledge is sometimes attended with gun-like reports sufficiently loud to be heard at a considerable distance. At the foot of cliffs in such regions are sharp angular flakes varying from small particles to masses of several tons. Many of these are so clear cut that the uninitiated may conclude that they have been torn from the mountain by the hand of man.

The small crevices produced by the intermittent heating and cooling soon become filled with water, and during the cold nights of autumn this changes into ice. Water on freezing expands 9 per cent and may exert a force of 150 tons to the square foot. This is sufficient to tear off huge rocks, which if on the mountain side roll into the valley below where they are slowly ground into smaller and smaller particles. When water enters a very porous rock and then freezes the rock may be quickly disintegrated. 
Cleopatra's Needle is a good example of this disintegration of rock by freezing. This granite obelisk had stood for centuries without injury in the warm equable climate of Egypt. On being removed to New York, however, it was found necessary to coat the surface with paraffin to keep out the water; otherwise, the inscriptions would soon have been completely obliterated.

In the temperate regions the wide daily fluctuations of temperature are potent factors in the disintegration of rock. Moreover, it keeps the soil and of ten the subsoil open so that both air and water may enter. These accelerate the chemical and biological factors going on within the soil.

The superiority of fall plowing is due in a large measure to freezing. The freezing disintegrates the rock and liberates more plant-food, and the heaving of the soil leaves it more open, thus improving tilth.

Wind.-One must live in a dry-windy climate to fully appreciate the importance of wind in soil formation. The wind free from sand accomplishes little, but when laden with the sharp angular sand of arid districts it becomes a powerful engine for modifying the surface of the earth. The sharp grains of sand while in the air are ground against each other and blown against the surface of rocks with such force that cliffs are slowly worn away. We of ten see in mountainous districts fantastic shapes which have been carved by the continuous impact of the sand. The effectiveness of wind decreases as the distance from the surface of the earth increases. Hence, we often find huge pearshaped bowlders which have been carved by the wind. In time they topple over, and the work of undermining is repeated.

The effectiveness of wind laden with sand is well illustrated in the fact that telegraph wires along the Trans-Caspian Railway have had to be renewed after eleven years, for the continuous impact of the sand had reduced the wire to one-half its original diameter. It is also found necessary to protect by means of piles of rock or short additional posts the telegraph poles along the Southern Pacific Railway through the San Bernardino Pass in Southern California in order to save them from the driving 
sands. The effectiveness of the sand blast is recognized in the industries where it is often used for the grinding of hard surfaces.

Wind plays a tremendous part in the transporting of soils. Emerson states, "Dust storms are not uncommon even in humid regions, and a strong wind may in a few hours carry away one one-hundredth of an inch of soil. At this rate it would require only one hundred winds to move one inch of loose material and only I,200 winds to move a foot, a rate that, from a geological point of view, is comparatively rapid." It has been estimated that the transporting power of winds over the Mississippi Basin is about one thousand times as great as the transporting powers of the Mississippi itself. Moreover, it is stated that every square mile of the earth's surface contains soil from every other square mile carried to it by the atmosphere.

There have been times in Colorado when sanddrifts a foot high have been piled on a railroad track in half an hour, thirteen carloads of sand being removed from a single platform on one occasion. The soils of the famous palouse wheat regions of eastern Washington, eastern Oregon, and northern Idaho were probably formed in just this manner.

Running Water.-The transporting and erosive power of water is apparent to all who have looked into a stream. One can see at almost any time grains of sand and rocks of various sizes, rolling, hopping, sliding, along the bottom of the stream. These grind against one another and against rocks in the beds and banks of the streams, slowly but continuously scouring out its bed and reducing the rocks to finer particles. The speed with which this result is accomplished varies with the volume and speed of the current. If a stream's velocity is doubled the carrying power is increased sixty-four times. With this in mind, one can understand how a stream in flood can transport even large bowlders. Thus, all streams are continuously transporting sand, rock, or soil from the higher to the lower levels. A natural barrier may impede the flow of the stream, then it stops to "pause for a sleep and dream." But after this sleep, how it romps and plays in the gathering of another load! 
"As soon as a stream is fairly over the lake lip it breaks into a cascade, never for a moment halting, and scarce abating one jot of its glad energy until it reaches the next basin. Then swirling and curving drowsily through meadow and grove it breaks forth anew into gray rapids and falls, leaping and gliding in glorious exuberance of wild bound and dance down into another and yet another lake basin." Many of the best agricultural soils were formed in just this way, and they owe their great depth and great fertility to their method of formation.

Action of Waves.-The wind lashes the water of lakes and oceans against their shores and in so doing rolls rocks up and down their beaches. This action, together with the various suspended substances in the surf, slowly wears away the rock. Throughout the Great Basin the history of the extinct lakes may be read from the wearing effect of their waters upon the surrounding mountains.

Ice.-In the early geological periods great sheets of ice covered many parts of North America. These flowed slowly as does water from the highlands into the lowlands. On their journey they froze around monstrous bowlders which they dragged slowly along, grinding one another and the underlying rock into a fine powder. Rocks from the overhanging cliffs were caught up by the surface of the glacier and transported to lower levels.

Volcanoes.-During the eruption of volcanoes large quantities of lava, gases, and fragments are ejected. The lava is a solution of various minerals made fluid by heat. This of ten flows from vents as would water. Some lavas flow only a short distance before becoming chilled and stiff. However, the basic lavas which yield the best soil of ten flow long distances and cover large areas. In earlier geological times such floods of lava overspread areas in Idaho, Washington, and Oregon, estimated at over 200,000 miles in extent and with an observed thickness in places of hundreds of feet. These easily weather, yielding deep productive soil which under favorable moisture conditions is very fertile.

The solid matter thrown from volcanoes consists of large 
blocks of hardened lava and small fragments. The ash consists of volcanic sand, cinders, and still finer volcanic dust. Volcanic dust may be carried great distances before being deposited. Widespread formations in Nebraska and adjacent states contain beds of volcanic dust, the origin of which is unknown for there are no probable sources within hundreds of miles. It is stated that millions of acres have an appreciable quantity of volcanic dust in their soils. It is probable that nearly every square mile of the earth's surface contains some volcanic dust.

\section{CHEMICAL AGENCIES}

We have seen that in the process of soil formation the rocks are pulverized, but the process of making soils consists in something more than the grinding of rock. At the same time that the particles are becoming smaller certain other transformations are going on which change the chemical nature of the soil. The agents at work we can conveniently consider under the heading of atmosphere and water.

Atmosphere.-The atmosphere consists of a mechanical mixture of about four volumes of nitrogen and one volume of oxygen. In addition to these it contains very small but important quantities of carbon dioxid, nitric, sulfuric, and other acids. It also contains small but appreciable quantities of ammonia.

Iron exposed to the air rusts. In so doing it changes in color, volume, and solubility. Many rocks contain appreciable quantities of iron, and on exposure to the atmosphere oxidation takes place. The resulting mineral being more bulky crowds the grains of rock apart. Water slowly dissolves out the new compound, and the rock soon falls prey to other agents.

Many rocks contain sulfides. These are oxidized with the formation of sulfates which are soluble and hence are readily washed from the parent rock. One may at times see clear-cut crevices which have been thus formed in rocks.

Complex silicates, such as feldspar, mica, and hornblend, are often attacked by oxygen and carbon dioxid and reduced to simpler and more stable compounds. 
Carbon dioxid probably plays even a more important role in the weathering of rock than does oxygen. This unites with water which readily carries into solution marbie or reacts with the calcium, magnesium or iron of complex silicates with the formation of soluble compounds. These on being carried away cause the rock to crumble. This is an important cause of the disintegration of granite. When rocks take up carbon dioxid, as occurs in the true carbonation, they increase in bulk and thereby rupture some of the rocks.

The sulfur brought to the soil from the atmosphere often amounts to 40 pounds per acre annually. This is oxidized by bacteria to sulfuric acid which readily attacks even the more resistant rocks.

In addition to this, small quantities of ammonia, nitric acid and other acids are continually being carried from the atmosphere to the earth. They likewise play their part in rendering soluble the constituents of the rocks.

Water.-Water is a universal solvent, as is exemplified by the fact that pure water is a chemical curiosity found only in the laboratory where it is obtained with great difficulty. Hence, just as fast as the other weathering agents render the rock constituents soluble they are dissolved by the water, and where the rainfall is sufficient they are leached from the soil. It is estimated that the rivers of North America carry to the ocean each year 474,000,000 tons of soluble constituents-a quantity sufficient to cover one hundred acres to a depth of nearly three thousand feet.

Although pure water slowly dissolves the more insoluble rocks, yet when it becomes charged with carbon dioxid from the atmosphere or from the decay of organic matter its solvent powers are increased many times. Such water dissolves limestone, gypsum, and similar rocks comparatively fast. In limestone regions rocks are often furrowed by rivulets which charged with carbon dioxid have flowed over their surfaces.

It is estimated that the surface of certain limestone regions has been lowered at rates varying from one inch in twenty-four 
years to the same amount in 500 years. Water also has an appreciable solvent action on feldspar, granite, and even quartz. Sandstones with calcareous cements are disintegrated by the solution of the cement, causing the rock to fall to pieces and form sand.

Moreover, many minerals combine with water. This is known as hydration and plays a very important part in weathering. During hydration the mineral increases in volume and of ten becomes soluble. Building stones which are uniform in color when first quarried sometimes become discolored on exposure to the rain and air. The discoloration is due to the action of water and oxygen upon the iron pyrite in the stone with the formation of sulfuric acid which readily reacts with the rock.

\section{BIOLOGICAL AGENCIES}

Bacteria as Soil Formers.-Early in the history of soil formation bacteria appear and play an essential part in rendering the soil fertile. Their life activities result in the production of carbon dioxid, organic and inorganic acids, and alkalies. These react with the constituents of the rock particles, changing their solubility. When water becomes charged with these acids produced by bacteria its solvent powers are greatly increased.

Common limestone is one of the rocks most actively attacked by carbonated water; none are wholly resistant to its action. Even quartz is slowly dissolved. Granite and related rock are rather quickly acted on by water due to the feldspar minerals which it contains. The bases-potash, soda, lime, and alumina,are dissolved out. The last is deposited as clay, the first as beneficial or injurious soil constituents, depending on the kind and the concentration left in a particular soil. In a similar manner the sulfur, iron, and phosphorus of the soil are changed to available forms.

Moreover, bacteria play a very important part in the mineralization of plant and animal residues which continually find their way into the soil. The phosphorus, sulfur, iron, calcium, mag- 
nesium, and potassium in the plants and animals are mainly in the form of organic compounds, and as such are not available to other plants. Bacteria decompose them liberating carbon dioxid, ammonia, hydrogen sulfide, sulfuric acid, and the mineral constituents which are rendered available as plant-food. In this manner, the biological activities become of the utmost importance in the transformation and migration of mineral substances in nature. The bacteria act, therefore, as the link between the $\mathrm{liv}$ in $g$ and the dead.

Soil bacteria are continually p r oducing large quantities of carbon dioxid, nitrous, ni-

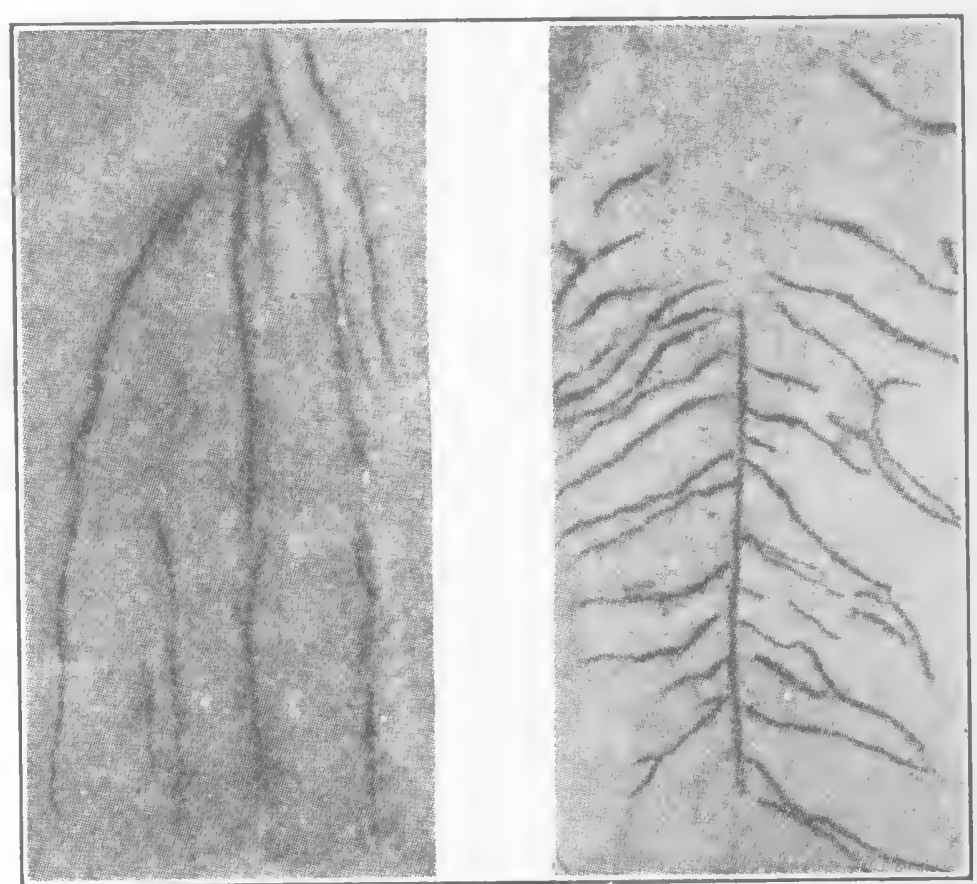

Etching of Marble by Plant Roots

FIG. 23. - The picture on the left shows the solvent action of plant roots on a marble slab in the absence of bacteria; the one on the right the action in the presence of bacteria. The latter have formed acids from the material given off by the plant and have increased the solvent action on calcium carbonate. (After Fred.)

tric, and sulfuric acids, together with organic acids which are in the main combined with calcium or magnesium of the soil with the formation often of a soluble compound. The waters carry these to the lakes, seas, and oceans - there to be taken up by marine life. In the course of time these are deposited as coral reefs, chalk cliffs, and marl beds. At times the speed with which the lime is taken from the waters by marine life is faster than it is carried into a lake by its tributaries. The result is that in spite of the evaporation and concentration which is going on, the main body of water contains less lime than does its tributaries. This is the case with Bear Lake, Utah, the tributaries of which have an 
average lime content of 101.7 parts per million, whereas the lake contains only I 3.2 parts per million.

Calcium Carbonate.-The loss of lime from a soil varies with (I) the methods of agriculture, intense methods increasing the loss; (2) the application of animal manures and green manures, which increases the bacterial activity and also the solubility of the calcium carbonate; (3) the addition of commercial fertilizers to a soil hasten the loss of calcium in drainage water.

The numerous acids produced by bacteria react with limestone rendering it soluble so it can be carried away in the drainage waters. Therefore, the absolute amount lost varies with the water reaching the soil as well as the composition of the soil. Hall estimates that the annual loss from the Rothamsted soil which contains about 3 per cent of limestone is from 800 to $\mathrm{I}, 000$ pounds an acre annually, whereas in this country where liming is necessary the farmers usually provide for a loss of 400 pounds an acre annually.

Bacteria, by the liberation of carbon dioxid, may also produce small quantities of limestone. This enables many soils which contain only very small quantities of lime to retain their neutral reaction and continue to produce fair crops. This, however, is not always the case, as is witnessed by the acid soils occurring in many districts.

Phosphorus.-Phosphorus occurs in the soil mainly in the form of calcium, iron, or aluminum phosphate. Moreover, as soluble phosphorus compounds are applied to a soil they are changed to insoluble compounds. There are also small quantities of organic compounds of phosphorus. All of these are only slightly soluble, but bacteria act on the organic phosphorus compounds and render the phosphorus available to plants.

In this general process of decay the nitrogen passes through the forms of ammonia, nitrous and nitric acid, and at the same time the carbon passes into various acid compounds including the complex humic and ulmic acids and the simpler acids-acetic, lactic, and butyric. The final product of the carbon is carbon dioxid. 
Now, these various nitrogen and carbon acids readily change the phosphorus into soluble phosphorus. Actual experiments show that about one pound of phosphorus and two pounds of calcium are made soluble by the oxidation of one pound of nitrogen. Twelve out of twenty of the bacteria obtained from soil by one worker exerted a definite solvent action on difficultly soluble plant-food. Some of these acted by means of carbon dioxid, others by means of acids. Most of these bacteria are the common ammonifiers. The nitrogen-fixing organisms produce many acids, and under good conditions they can generate one and threetenths times their own weight of carbon dioxid during twentyfour hours. This dissolves in water and attacks even ordinary quartz rock; granite, and rocks related to it are rather quickly attacked, with the liberation of potassium and other elements. It is also certain that the carbonated waters would change the insoluble phosphates into an available form.

Sulfur.-Sulfur is an essential element for all plants. The quantity required by plants is small, and although the quantity in some soils is small yet determinations at the Illinois Experiment Station show that about forty pounds are brought to the soil annually in rain water. This is acted upon by bacteria, with the production of sulfuric acid which would liberate plant-food. The sulfur of the soil is mainly in the form of sulfates or organic sulfur.

Bacteria act on sulfur compounds in three ways: ( 1 ) They decompose organic compounds with the formation of hydrogen sulfide or other ill-smelling gases; (2) they oxidize sulfur compounds of the soil; and (3) the true sulfur bacteria act on hydrogen sulfide and other sulfur compounds with the production of metallic sulfur, sulfuric acid, and eventually mineral sulfates. The majority of the common putrefying bacteria produce hydrogen sulfide. Many of the disease-producing bacteria produce this gas when growing in an appropriate medium. Not a few soil organisms will reduce the sulfates to hydrogen sulfide.

The two classes of the true sulfur bacteria act opposite to 
this. They act on hydrogen sulfide and produce sulfur. Yellow granules of sulfur may often be seen in their bodies. If transferred to fresh water these granules disappear and sulfuric acid is produced. This would render available more plant-food. Today some workers are advocating the mixing of sulfur, insoluble phosphates, and bacteria. The bacteria oxidize the sulfur which in turn liberates the phosphorus. Probably considerable of the benefit resulting from the addition of sulfur to some soils comes from this reaction. Aeration and optimum moisture favor the change, whereas carbohydrates depress it.

Iron.-The iron bacteria resemble the sulphur bacteria greatly in their metabolic processes. They oxidize iron. They probably play a great part in the formation of bog iron. The water of some regions appears normal on being brought to the surface, but on standing it takes a yellowish color. The yellowish scums and deposits one sometimes sees around artesian wells are due to bacterial action. The water in both cases contains great numbers of iron bacteria. On coming in contact with the air, the iron of their body is oxidized, thus giving the yellow color.

Potassium.-This element is required by all plants in comparatively large quantities, and the total supply in soils is comparatively large as compared to crop requirements. Yet potassium is used extensively as a fertilizer, and this with beneficial results. This is due to the fact that its addition to a soil well supplied with available potassium results in the liberation of more deficient plant elements. Moreover, it may be applied to a soil having a large quantity of total potassium but small quantities available to plants. Hence, shall we add potassium to soils or render that which they already possess available? If the latter: How can it be rendered available? We have seen that bacteria produce nitrous, nitric, sulfuric, acetic, lactic, butyric, and carbonic acids. These would act upon the potassium containing silicates and render the potassium available to the plant. We have learned that cultivation, the addition of animal manure, green manures, and commercial fertilizers, all increase bacterial activity. Hence, this is the method by which the potassium can be rendered available. 
CHAPTER IX

\section{SOIL TEXTURE, STRUCTURE, AND COMPOSITION}

The problem of maintaining a fertile soil and at the same time harvesting from it large crops is founded on principles similar to the maintaining of a savings account. A sound bank account is founded on the following principles: ( $\mathrm{x}$ ) The institution must be maintained on sound principles. It must be able to keep the money safe and refund it when called for. (2) The amount which is in the bank to one's credit may be money inherited or that obtained by one's own effort. (3) The speed with which the money can be withdrawn depends upon the contract entered into with the bank. The duration of the account will depend upon the quantity on deposit and the speed with which it is withdrawn.

Now, in soil fertility we have three similar fundamental principles: (I) The texture and structure of the soil. Is it of such a nature that it will hold our capital, the fertility, and yield it to us as desired in the form of large crops? (2) The elements of plant food which it contains constitutes our bank account of fertility. The quantity of this is measured by the native fertility which the soil contains plus the plant-food added to it from time to time. (3) The biological factor, the tiny microbes, which correspond to the contract determining the speed with which the capital can be withdrawn. In the banking business all recognize the fact that they can draw out only that which is placed to one's account. In fertility the same principle holds. One cannot obtain something from nothing.

SOIL TEXTURE AND STRUCTURE

Soil Classes.- Soils may be classified as to origin as:

(I) Residual Soils-These are formed in place through the decomposition and disintegration of the native rock. By dig- 
ging down to varying depths, depending upon the soil, one may find native rock similar to that from which they were formed. However, these soils of ten consist of only a small fraction of the native rock from which they were derived. For example, a soil derived from a limestone composed of 60 per cent of calcium carbonate and 40 per cent of impurities may on complete weathering consist almost entirely of the impurities plus varying quantities of organic matter.

(2) Transported Soils-These are soils the material of which has been moved from its native origin by means of gravity, water, ice, or wind. These soils are known as colluvial or gravity-laid soils, sedimentary or water-laid soils, glacial or ice-formed soils, and eolian or wind-formed soils, depending upon the means used in their transportation. They vary in composition, depending upon the native rock from which they were derived as well as upon the material added to or subtracted from them in transportation. About 90 per cent of the soils so far mapped in the United States are transported soils.

Soils may also be classed as to physical composition as (I) sand, (2) sandy loam, (3) loam, (4) clay loam, (5) clay, and (6) peat. This classification is based upon the size and composition of the ultimate particles which compose the soil.

Soil Texture.-Soil texture refers to the size of the particles which compose a soil. We may have soils of fine or coarse texture just as we have cloth of fine or coarse texture, depending upon the size of the particles which compose it. It has been estimated that a sandy soil containing only 4.77 per cent of clay contains 2,000,000,000 particles in one gram, whereas a soil containing 32.45 per cent of clay contains $15,000,000,000$ per gram. Soils adapted to the growth of various crops contain varying numbers of soil particles, as is shown in the following.

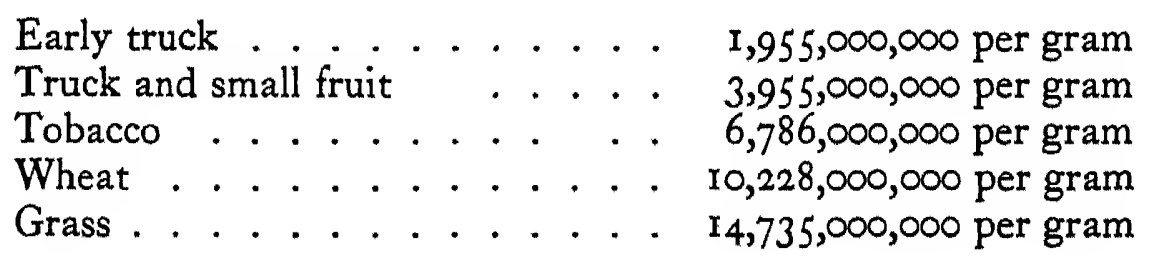


These particles as they exist in a soil are not in close contact but are surrounded in a dry soil by a film of air and in a moist soil by a film of water. The space occupied by this air or water in natural conditions of ten equals one-half the entire mass. Work indicates that for maximum bacterial activity this should be composed of 60 per cent of water and 40 per cent of air.

We more fully appreciate the action of water, plants, and bacteria on these particles when we are told that the total surface of all the grains of soil found in one cubic foot would be equal in area to from two to three acres. A soil composed of the larger particles such as sand is referred to as a light soil, although a unit volume weighs more than does a soil containing much clay which is called a heavy soil. A light soil is more easily cultivated than is a heavy soil. It also loses its water more rapidly and warms up earlier in the spring; hence, it is referred to as a warm or early soil.

The texture of a soil depends upon the rock from which it has been derived and also upon the methods of formation. The weathering of sandstone results in a sandy soil. The weathering of shale on the other hand yields clay soils. Soils which have resulted from the grinding of native rock with little weathering yield soils of coarse texture. Older weathered soils are of a finer texture than are younger. The bacterial activities of a soil are dependent on the texture of the soil, as will be shown later.

Soil Structure.-Soil structure signifies the arrangements of the particles which constitute the soil. The particles may be separate so each can move freely or they may be arranged in small groups as granules which act as a single particle. The former is known as the separate-grain structure and the latter as the granular or crumbly structure. Good tilth in clay and loam implies a granular structure, and poor tilth a separate-grain structure.

The conditions affecting structure are (I) texture, (2) quantity of organic matter present, (3) lime, (4) presence or absence of alkali salts, (5) wetting and drying, (6) freezing and thawing, (7) tillage, and (8) plants and animals.

Nothing the farmer can do will modify the texture of the 
soil, but the structure can be quite nicely controlled by proper methods of tillage and the addition of organic manures either in the form of barnyard or green manures. Lime can be added to an acid soil and gypsum to a black alkali soil. Fall plowing greatly modifies the soil structure by the permitting of weathering due to frost.

The bacterial flora of a soil is related to soil structure and the modification of structure modifies bacterial activity. The addition of lime to an acid soil makes of it a fit abode for the nitrifying and nitrogen-fixing bacteria. Manure contains bacteria, and when it is added to the soil these and the soil organisms break down the organic constituents of the manure with the formation of acids. These in turn liberate more plant-food. Beneficial bacteria do not function in alkali soil; hence, anything that will reduce the alkali also increases the number and kind of bacteria. All the beneficial microbes are air-loving; therefore, proper cultivation and even fall plowing will increase the aeration of the soil and with it the bacterial activities.

The moisture content of a soil is frequently the limiting factor of crop production. The amount of water held by a soil is directly related to the soil texture. Light soils part with their moisture rapidly. On the other hand heavy soils hold it more tenaciously. Most beneficial bacteria require for maximum activity, that the water content of the soil be 60 per cent of its water holding capacity. It is, therefore, evident that the principles of maintaining good structure and good bacterial activities are the same. It is quite probable that the increased yields which come from keeping a soil in good tilth are directly due to increased beneficial bacterial activities.

Plant Requirements and Soil Composition.-The duration of a bank account is measured by the rate with which it is drawn from the bank and the capital on deposit. The same is true of fertility. The time it will last varies with the total fertility in the soil and the rate at which it is drawn from the soil. Hence, we must consider the plant requirements and the total quantity in the soil. 
Plant Requirements.-All agricultural plants require ten elements, and the growth of any farm crop is dependent upon a supply of these. If one is lacking there is no plant growth. The extent of plant growth is governed by the one present in least quantity in proportion to the plant's needs. Of these ten elements, all plants secure two elements from the air, one from the water, and seven from the soil.

Water, which constitutes from 70 to 90 per cent of the plant, comes wholly from the soil. Carbon and oxygen which compose 90 per cent of the dry matter of the plant are drawn from the air. The air is one-fifth oxygen; hence, the supply is inexhaustible. There is only one pound of carbon in 10,000 pounds of country air, but this is being continually renewed through the burning of coal, wood, and other material. Moreover, all animals return carbon to the air in large quantities as carbon dioxid. Therefore, we need not concern ourselves with the carbon supply of plants as it is automatically governed.

If we include hydrogen with the carbon and oxygen we account for 95 per cent of the dry matter of the plant. This is supplied the plant in the water. Therefore, we need concern ourselves with only seven elements which constitute only 5 per cent of the dry matter of the plant.

Nitrogen-The element taken from the soil by plants in largest quantities is nitrogen. It enters into the composition of the protoplasm of the plant. The lack of nitrogen in the soil results in a reduction of leaf surface, stunted abnormal growth, yellowing of the leaf, especially in cold weather. Excessive nitrogen given to cereals causes excessive production of straw with a great tendency to lodge. Beets produce excessive tops with small roots. Nitrogen-starved plants and also plants receiving excessive quantities of nitrogen are especially susceptible to attacks of insects and fungus pests.

Nitrogen differs widely from the other essential elements in the following. It does not constitute a part of the original earth's crust. It belongs exclusively to the atmosphere to which it constantly tends to return. In its atmospheric conditions it 
is not directly utilizable by higher plants or animals as are oxygen and carbon dioxid. When in the soil it tends to become soluble, and hence, leached from it by excessive irrigation water or rain. Most soils are deficient in nitrogen.

Phosphorus-The next element used by the plant in large quantities from the soil is phosphorus. It is required by every cell. It is necessary for the production of chlorophyll. In its absence neither starch nor sugar is formed in the leaf. To the farmer of the arid districts it is especially important for two reasons: (I) In the early stages of growth it promotes root formation to a remarkable extent. This is especially noted in clay soils where there is a tendency for scant root formation. (2) In the later stages of growth phosphorus hastens ripening. In northern districts where frost is a menace this may at times be an important factor. At maturity the phosphorus has accumulated to a large extent in the seeds. Many soils are deficient in phosphorus.

Potassium-This element is demanded by all plants but by some in larger quantities than by others. Potatoes and sugarbeets require it in large quantities, as it seems to play a vital part in the formation of starch and sugar in the plant. Potassium starvation is even more easily detected than phosphorus starvation. Potassium-starved plants have a dull, poor color and tend to die early at the tops. Beets are low in sugar. Grains are under weight. Potassium-starved plants are the first to succumb to disease. During the ripening of the plant the potassium of the leaves and stalks becomes soluble, and hence may be washed back into the soil. Few soils are lacking in potassium, although many soils show an increased yield on applying potassium salts. This may be due to the soil having little available potassium, or the added potassium may liberate other essential needed elements.

Calcium-This element gives tone and vigor to the plant. It occurs more in the leaves and stems than in the seed. All soils have sufficient calcium for plant needs. Some soils may be acid, under which condition they are benefited by the addition of lime- 
stone or lime. Calcium sulfate is of ten used to correct the ill effect of black alkali.

Magnesium-Magnesium differs from calcium and potassium in that as the plant ripens it migrates to the seed. Magnesium is essential in the production of chlorophyll. Hence, magnesiumstarved plants have an unhealthy color. Excessive amounts produce harmful effects which can be corrected by calcium.

Iron-Plants do not possess their healthy green color when iron is lacking. Although iron is essential for the production of chlorophyll, yet it does not enter into its composition. Very small quantities are needed by plants. All soils contain sufficient iron.

Sulfur-Cabbage and root crops require more sulfur than do other crops. It gives to garlic, horseradish, and onions their peculiar taste and odor. These plants grown in soils containing small quantities of sulfur are mild. Small quantities of sulfur are essential to all plants as it enters into the production of the proteins. Probably most soils contain sufficient sulfur for plant needs, yet the addition of sulfur to a soil is of ten accompanied by increased yields. This may be due to sulfur bacteria changing the sulfur to sulfuric acid which liberates phosphorus or other plant nutrients in the soil.

We have seen that the three elements which are used by the plant from the soil in largest quantities are nitrogen, phosphorus, and potassium. The money value and quantity of these required by the wheat, potato, and sugar-beet crops are given below.

\begin{tabular}{|c|c|c|c|c|c|c|c|c|}
\hline \multicolumn{2}{|c|}{ Product } & \multicolumn{3}{|c|}{ Pounds } & \multicolumn{3}{|c|}{ Market Value } & \multirow{2}{*}{$\begin{array}{l}\text { Total } \\
\text { Value }\end{array}$} \\
\hline Kind & Amount & $\begin{array}{c}\text { Nitro- } \\
\text { gen }\end{array}$ & $\begin{array}{l}\text { Phos- } \\
\text { phorus }\end{array}$ & $\begin{array}{l}\text { Potas- } \\
\text { sium }\end{array}$ & $\begin{array}{c}\text { Nitro- } \\
\text { gen }\end{array}$ & $\begin{array}{l}\text { Phos- } \\
\text { phorus }\end{array}$ & $\begin{array}{l}\text { Potas- } \\
\text { sium }\end{array}$ & \\
\hline Wheat & $50 \mathrm{bu}$. & $7 \mathrm{I}$ & I 2 & I3 & $\$ 10.65$ & $\$ .36$ & $\$$ & $\$ 11.79$ \\
\hline Wheat-straw & 2.5 tons & 25 & 4 & 45 & 3.75 & .12 & 2.70 & 6.57 \\
\hline Wheat crop & & 96 & 16 & $5^{8}$ & I 4.40 & .48 & $3 \cdot 48$ & I 8.36 \\
\hline Potatoes & $300 \mathrm{bu}$. & 100 & I3 & 90 & 9.45 & .39 & 5.40 & I 5.24 \\
\hline Sugar-beets & 20 tons & 100 & 18 & I 57 & 15.00 & .54 & $9 \cdot 42$ & 24.96 \\
\hline
\end{tabular}


That is, every time we harvest a fifty-bushel crop of wheat from the soil we remove ninety-six pounds of nitrogen, sixteen pounds of phosphorus, and fifty-eight pounds of potassium.

It is evident now that the sane method of procedure would be to examine our bank account of soil fertility and see which is going to give out first, if drawn on in these proportions. One method of examination would be to examine the crust of the earth as a whole and find out its durability for crop production under this condition. The manner of doing this is shown in the following table:

Relative Supply and Demand of the Six Elements Essential to Plant Production

\begin{tabular}{|c|c|c|c|c|c|}
\hline $\begin{array}{c}\text { Essential } \\
\text { Plant-food } \\
\text { Element }\end{array}$ & $\begin{array}{c}\text { Pounds in 2,- } \\
\text { ooo,ooo of } \\
\text { Average Crust } \\
\text { of Earth }\end{array}$ & $\begin{array}{c}\text { Pounds in } 50 \\
\text { Bushels of } \\
\text { Wheat (grain } \\
\text { only) }\end{array}$ & $\begin{array}{l}\text { Number } \\
\text { Years } \\
\text { Supply } \\
\text { Indicated }\end{array}$ & $\begin{array}{c}\text { Pounds in } \\
20 \text { Tons } \\
\text { of } \\
\text { Sugar-beets }\end{array}$ & $\begin{array}{l}\text { Number } \\
\text { Years } \\
\text { Supply } \\
\text { Indicated }\end{array}$ \\
\hline Phosphorus & 2,200 & I 2 & 183 & I 8 & 123 \\
\hline Potassium & 49,200 & 13 & 3,785 & I 57 & $3^{1} 3$ \\
\hline Magnesium & 48,000 & 4 & 12,000 & 16 & 3,000 \\
\hline Calcium & 68,000 & I & 68,000 & I2 & 5,666 \\
\hline Iron & 88,600 & 0.3 & 295,000 & & \\
\hline Sulfur & 2,200 & 0.1 & 22,000 & 4 & 5,500 \\
\hline
\end{tabular}

It is clear that in the average crust of the earth, phosphorus is the limiting element of crop production. There is, however, a variation from place to place. The maxima and minima of the three elements-nitrogen, phosphorus, and potassium-for soil in the United States as given by Hopkins are as follows:

I. In nitrogen-content from I,000 to 35,000 pounds

2. In phosphorus-content from I 60 to 15,000 pounds

3. In potassium - content from 3,000 to 60,000 pounds

Now let us examine two western soils, those from the Logan (Greenville) and Nephi, Utah, Experimental Farms. Their composition is as follows: 


\begin{tabular}{l|c|c|c}
\hline \hline & \multicolumn{3}{|c}{$3,600,000$ lbs. Soil } \\
\cline { 2 - 4 } & Nitrogen & Phosphorus & Potassium \\
\hline Logan (Greenville) & 4,904 & 2,700 & $\begin{array}{l}60,560 \\
87,840\end{array}$ \\
Nephi Dry-farm & 3,744 & 8,388 & 87, \\
\hline
\end{tabular}

These soils are below the average in nitrogen, above the average in phosphorus, and up to the maximum in potassium. The surface foot of the soil of the Greenville farm contains sufficient nitrogen for fifty-one 50-bushel crops of wheat, enough phosphorus for 169 crops, and sufficient potassium for $I, 045$ wheat crops. The Nephi Dry-farm soil has sufficient nitrogen for thirty-nine 50-bushel wheat crops, phosphorus for 523, and potassium for I, 5 I 4 50-bushel wheat crops.

It is, therefore, evident that in both of these soils the limiting element in crop production is nitrogen which soon must be replaced; otherwise, maximum crops cannot be produced. The time when the phosphorus will become the limiting element is much more distant, whereas the potassium problem is one for the future. The problem then which confronts the users of these soils is to learn how to render the phosphorus and potassium available as needed by the growing plant and how to add the nitrogen to the soil. This can be accomplished by means of soil bacteria. Therefore, the present problem in soil fertility for these and many other western soils is a problem in soil bacteriology.

\section{THE BIOLOGICAL AGENCIES IN THE SOIL}

The microörganisms of the soil are the means of maintaining the nitrogen of our bank account of soil fertility and the means by which we can unlock the phosphorus and potassium and obtain it in the form of maximum crops. Hence, how many microörganisms are there in the soil? Are there different classes? If so, what are their functions?

The microörganisms of the soil can be divided into two classes: 
(I) The microscopic animals which we refer to as the microfauna of the soil. These are either unimportant or else detrimental. (2) The microscopic plants of the soil which we often speak of as the microflora. These are either injurious or beneficial. The problem of soil bacteriology is to know how to suppress or eliminate the injurious bacteria and at the same time increase the number and activity of the beneficial.

Number of Bacteria in Soils.-The number of bacteria in soils varies with the climatic conditions of the soil, the composition of the soil, the quantity of organic matter and water, and the methods of tillage and cropping. A sandy soil practically devoid of organic matter may have only a few thousand in a gram of soil. On the other hand, a silty loam containing large quantities of organic matter may have as many as fifty million in one gram. The number of bacteria in good arable soil well supplied with organic material usually ranges from three to forty millions. Tight non-porous soils, as well as alkali soils low in humus and moisture, have fewer bacteria. The number of bacteria in light, sandy, very tight clay, desert, and forest soils is usually much smaller, other things being equal, than in normal cultivated soils. The average of several hundred determinations made on cultivated soils of the arid regions gave a bacterial count in round numbers of 4,500,000 per gram. This appears to be an enormous number of bacteria to be crowded into such a small space. One may think they would not have elbow room, but if we recall that one gram of soil contains from two to twenty billion particles then each microbe in the soil of finer texture would be lord over about 5,000 particles; in the coarser texture soil each organism would be master of 500 particles. This would give to each microörganism more room in proportion to size than human individuals often have in large cities in proportion to their size.

Factors Influencing Numbers.-The quantity and kind of organic matter is one of the greatest factors governing bacteria in a soil. Large quantities of easily decomposed material increase the bacteria of a soil. The addition of five tons of barnyard manure to one of the arid soils increased the numbers 50 per 
cent, while ten tons of manure increased the numbers 75 per cent. In soil deficient in organic matter the increase due to manure may be many times greater than this. The addition of sugar and various other easily decomposed carbohydrates may increase the numbers even more than do manures. One of the great benefits coming from the use of manures is the great increase in the bacterial flora.

Bacteria like higher plants are dependent upon a suitable temperature. They cannot multiply in a frozen soil. Although we often find that the number in a soil is increased after freezing this is due to many factors. The loosening up of the soil, suppressing of microörganisms which feed upon bacteria, and the actual stimulation which comes from the cold-all of these may be responsible.

We have seen that bacteria are directly dependent upon moisture for their life activities; hence, we find the number varying with the moisture content.

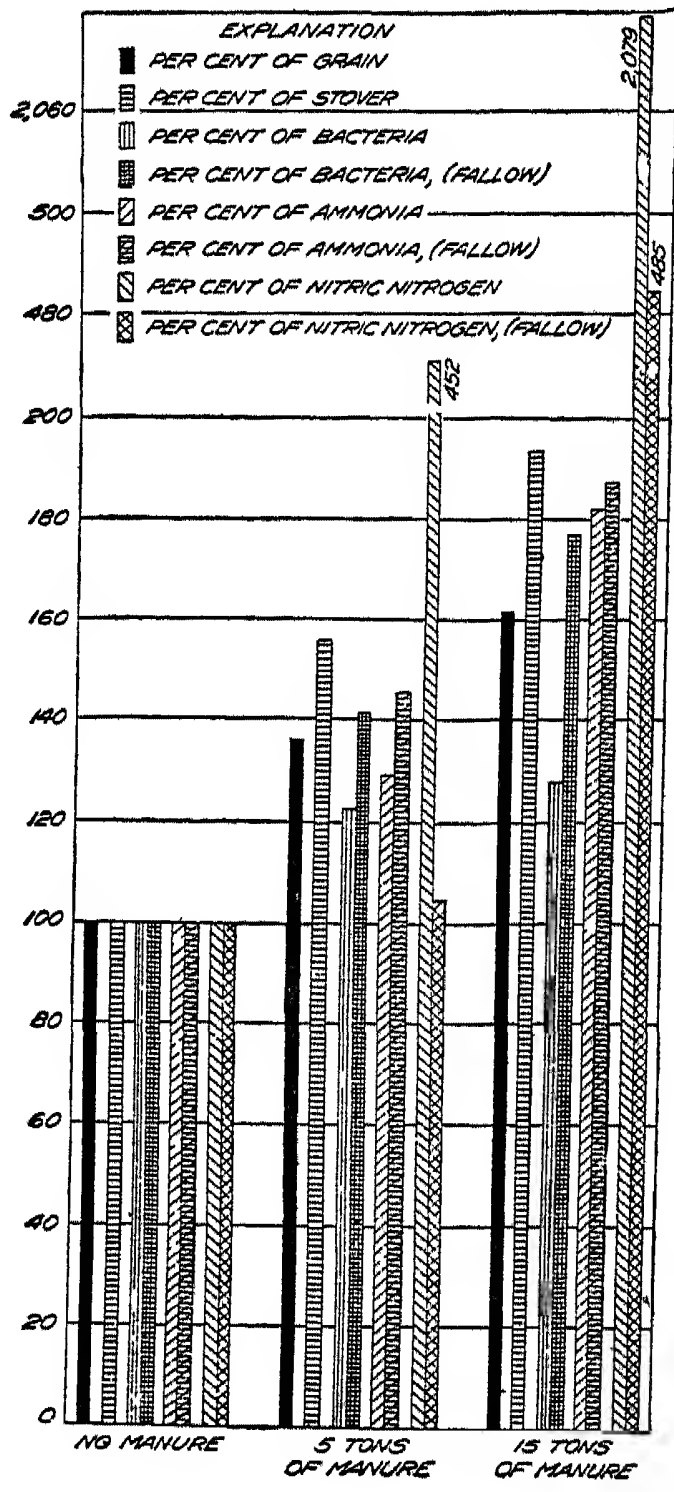

FIG. 24. - Relationship between crop and bacteria in a soil. They increase with the moisture, probably until about 70 per cent of the water-holding capacity of the soil is reached. Then as the water increases the number of bacteria decreases.

Alkali soils support a sparse, special vegetation. The same is true of the microflora of an alkali soil. A soil containing large quantities of alkali contains few bacteria but a considerable num- 


\section{BACTERIA AND SOIL FERTILITY}

ber of molds. After leaching from the soil alkali we of ten find that it takes a number of years before the soil becomes productive. This period of unproductivity can be shortened by adding to the soil other fertile soils, thus carrying to it a bacterial flora. Acid soils contain few bacteria and many molds. A soil rich in the essential elements of plant production, other things being equal, has a numerous bacterial flora. Limestone soils always contain a numerous and varied microflora.

Antiseptic and weak poisons added to a soil first decrease and then increase the number of bacteria. Possibly the weak poison kills some of the weaker permitting the remainder to multiply unhindered. Some workers claim that the weak poisons destroy the microfauna which normally would feed upon bacteria.

Nearly all beneficial soil microörganisms are aerobic; hence, we should expect to find all methods of treatment which keep the structure of the soil in good condition to increase soil bacteria. Cultivation, subsoiling, and fall plowing all increase the air entering a soil and also the number of bacteria within it. We find a close relationship between the crop grown on a soil and the number of bacteria, as may be seen from figure 24, page 93.

Probably one of the governing factors is aeration, as we find fallow soil and soils on which hoed or cultivated crops are grown high in microörganisms, whereas the grasses and haylands become tight and impervious to air contain smaller numbers.

\begin{tabular}{c|c}
\hline Depth & Number of Colonies \\
\hline 2 inches & 981,000 \\
4 inches & $1,632,000$ \\
6 inches & $1,623,000$ \\
I2 inches & 73,000 \\
I8 inches & 21,000 \\
24 inches & 4,000 \\
\hline
\end{tabular}

Variation with Depth.-The number of organisms in the soil vary greatly with the depth. Due to the lack of moisture and germicidal action of light, the number of bacteria in the upper- 
most inch or two of soil is lower than in the layers of soil immediately below. Beyond the depth of eight or nine inches, the number diminish rapidly, and in humid regions the number below two feet is extremely low. This is illustrated by results reported by Chester on facing page.

The conditions, however, are quite different in the arid regions where we have the slow formation of clay substances in the soil, and therefore the absence of the cementing substances. This results in greater aeration, and hence offers ideal conditions for bacterial growth to a great depth. Moreover, the roots in search for water penetrate to a great depth in the soils of the arid regions. This results in an aeration of the soil and the supplying of organic matter to bacteria at a great depth. Lipman found the ammonifying organism at all depths to the tenth foot and at times the nitrifying organisms to a depth of eight feet. The nitrogen-fixing organisms seldom occurred below the third or fourth foot. We have found great numbers of bacteria in both dry-farm and irrigated soils of the arid regions in the second and third foot. The average of several hundred such determinations is given below;

\begin{tabular}{c|c|c}
\hline \hline \multirow{2}{*}{ Depth } & \multicolumn{2}{|c}{ Number of Colonies } \\
\cline { 2 - 3 } & Irrigated Soil & Dry-farm Soil \\
\hline I foot & $6,240,000$ & $4,372,000$ \\
2 feet & $1,760,000$ & $1,267,000$ \\
3 feet & $1,147,000$ & $1,174, \infty 00$ \\
\hline
\end{tabular}

The larger number found in the irrigated soil is due to the presence of a better supply of organic matter and not to the moisture supplied.

Kinds of Microörganisms.- Many methods have been used to classify bacteria of the soil. Some workers have classified them as to morphology, form and structure, others as to physiology and action upon the soil constituents. The last is the most important 
method, as it gives us an insight into the changes actually produced within the soil. We may for convenience consider them under the following heads:

I. Ammonifiers-Microörganisms which break down proteinaceous material with the liberation of ammonia; nitrifiers, microorganisms which transform ammonia into nitrates. Of these there are two classes, one which changes ammonia into nitrites, the other which changes nitrites into nitrates.

2. Denitrifiers-Microörganisms which liberate the nitrogen of nitrites or nitrates as free nitrogen.

3. Cellulose decomposing bacteria-Microörganisms which break down vegetable tissues with the formation of various acids. 4. Nitrogen-fixing bacteria-Microörganisms which take nitrogen from the air and buld it into their bodies. There are two classes of these organisms, one which lives free in the soil, the other which lives in conjunction with legumes. 


\section{CHAPTER $X$ \\ THE CARBON, NITROGEN, SULFUR, AND PHOSPHORUS CYCLES}

Plants contain ten essential elements, and these elements found in the body of the plants or animals today are the same as those which constituted the organic world thousands of years ago. But between these dates they have played many parts, or, in the words of Duncan, "We believe-we must believe in this day-that everything in the universe of world and stars is made of atoms, in quantities $x, y$, and $z$, respectively. Men and women, mice and elephants, the red belts of Jupiter and the rings of Saturn, are one, and all but evershifting, ever varying, swarms of atoms. Every mechanical work of earth, air, fire, and water, every criminal act, every human deed of love or valor: what is it all, pray, but the relation of one swarm of atoms to another?

"Here, for example, is a swarm of atoms, vibrating, scintillant, martial-they call it a soldier-and, anon, some thousands of miles away upon the South African veldt, that swarm dissolvesdissolves, forsooth, because of another little swarm-they call it lead.

"What a phantasmagoric dance it is, this dance of atoms! And what a task for the master of the ceremonies. For, mark you, the mutabilities of things. These same atoms may come together again, vibrating, clustering, interlocking, combining, and there results a woman, a flower, a blackbird, or a locust, as the case may be. But tomorrow again the dance is ended, and the atoms are far away; some of them in the fever germs that broke up the dance, others are the green hair of the grave, and others are blown about the Antipodes on the wings of ocean, and the eternal everchanging dance goes on."

Importance of Bacteria in Cycles.-In this building up and 
breaking down, bacteria plan a major part. The higher plants build up the carbon and nitrogen into complex organic compounds. The same end is also accomplished to a lesser degree by the animals which, however, mainly act as decomposers of organic matter, but the master analysts are the bacteria which are continually resolving into simple and of ten elementary constituents all plant and animal debris. Were this not true, all the carbon and combined nitrogen of the world would soon become locked up in the dead bodies of animals; plants would starve and die, and animals likewise would become extinct. Therefore, bacteria are the link between the living and the dead. The absence of bacteria is incompatible with life on this earth, or, as stated by Pasteur, "They are the important, almost the only, agents of universal hygiene. They clear away more quickly than the dogs of Constantinople or the wild beasts of the desert, the remains of all that has had life; they protect the living against the dead; they do more; if there are still living beings, if, since the hundreds of centuries the world has been inhabited, life continues, it is to them we owe it."

The Carbon Cycle.-Carbon occurs free in the earth as coal to the extent of over five hundred billion tons. Chemically combined, it is found in far larger quantities in limestone, chalk, marble, and dolomite--rocks which form such a considerable portion of the surface of the earth. According to Pettenkoffer, a man weighing 154 pounds contains 26.4 pounds of carbon. No less than two hundred and fifty-seven million tons' weight of it is, therefore, stored up in the bodies of men and women living upon the earth at the present time, to say nothing of the far greater quantities occurring in the tissues of trees, plants, and lower animals.

Carbon dioxid occurs in the atmosphere to the extent of three parts in 10,000 . This is the equivalent of six hundred billion tons of carbon. Moreover, the ocean is a vast reservoir of carbon dioxid which is partly in solution and partly combined. Between the surface of the sea and the atmosphere there is a continual interchange, each at times losing and at times gaining the gas. 
Carbon dioxid is being added to the air from several sources: the combustion of fuel, the respiration of animals, and the decay of organic matter. It is also being evolved in enormous quantities from mineral springs and volcanoes. Krogh estimates that the annual consumption of coal adds yearly to the atmosphere about one-thousandth of its present content in carbon dioxid. Were there no factors offsetting this increase in atmospheric carbon dioxid animal life would soon become extinct.

On the other hand, there are two large factors at work removing carbon from the atmosphere: (I) the decomposition of carbon dioxid by plants with the liberation of oxygen, and (2) the consumption of carbon dioxid in the weathering of rocks. No precise valuation can be given to either of these factors, although various writers have attempted to estimate their magnitude. Cook computes that leaf action alone more than compensates for the production of carbon dioxid. Chamberlain estimates that the amount of carbon dioxid annually withdrawn from the atmosphere is $1,620,000,000$ tons, and that the greater part of this is taken up by the weathering of minerals. This is continually being returned to the atmosphere by bacterial action. There are then two compensating sets of factors: (I) decay, respiration, and combustion liberating carbon; and (2) plant growth and rock-weathering fixing it. These balance each other, thereby completing the carbon cycle and rendering the carbon-dioxid content of the atmosphere nearly constant.

The Nitrogen Cycle.-Since nitrogen occurs as an essential part of the structure of every plant and animal, it is found in all crops and crop residues. It occurs in the top soil in proteins, protein decomposition products, ammonia, nitrites, and nitrates. It is not found in the mineral matter of the earth except in shales and other deposits containing the residues of plant and animal bodies. Hence, the quantity in the combined form is not great when compared with other essential elements. Yet it is required by all living organisms in large quantities. Many of these are returning it to its inert atmospheric form. This fact led Sir William Crooks, in his famous address before the British Asso- 
ciation for the Advance of Science in 1898 , to predict dire calamity to the human race if science were not able to utilize atmospheric nitrogen.

In the free form, nitrogen occurs in enormous quantities; fourfifths of the atmosphere is composed of it. Dr. Hopkins has pointed out that the total supply of nitrogen over each acre of the earth's surface, if available, would meet the needs of a hundredbushel corn crop every year for 500,000 years, whereas the supply of carbon is sufficient for such a crop for only two years. Nevertheless, carbon has no commercial value as plant-food, while nitrogen in available form is worth from 15 to 20 cents a pound in the market.

The same atom of nitrogen at different times plays many different roles. One of the triumphs of agricultural bacteriology is the advancement which it has made in following nitrogen through its cycle.

Nitrogen occurs in the plant and animal mainly in the form of protein. The plant protein may be eaten by the animal and produce animal protein. Either may reach the soil and decay. The nitrogen eaten by animals may be deposited as tissues of the animal or excreted as urea, hippuric or uric acid. These products are acted upon by bacteria with the formation of ammonia.

Either the plant or animal proteins may reach the soil where decay sets in with the formation of the simpler compoundsalbumoses, proteoses, peptones, peptids, and amino-acids. The amino-acids are then deaminized with the formation of an acid and ammonia. The process is spoken of as ammonification.

The ammonia does not accumulate in the soil but is acted upon by other bacteria, the nitrosomonas, with the formation of nitrous acid. This is quickly taken up by the nitrobacter and oxidized to nitric acid which reacts with bases in the soil with the formation of nitrates. The nitrates are the main source of nitrogen for the plants which build from them and carbon dioxid, amino-acids, peptids, peptones, proteoses, albumoses, and finally plant proteinsand the nitrogen has completed its cycle. If this were the whole story, the quantity of combined nitrogen in the world would 
remain constant. But it is not-there are many leaks in the cycle. Some of the plants and animals may be burned with the liberation of free nitrogen. Millions of pounds of it reach sewers, and from here rivers, lakes, and oceans. In time this is broken down and the nitrates so formed are reduced by denitrifying $b a c t e r i a$ with the liberation of gaseous nitrogen. The processes of de c a y continually going on may also liberate free nitrogen. Furthermore, millions of pounds of nitrogen a re returned to the air by explosives. In some of the battles of the World

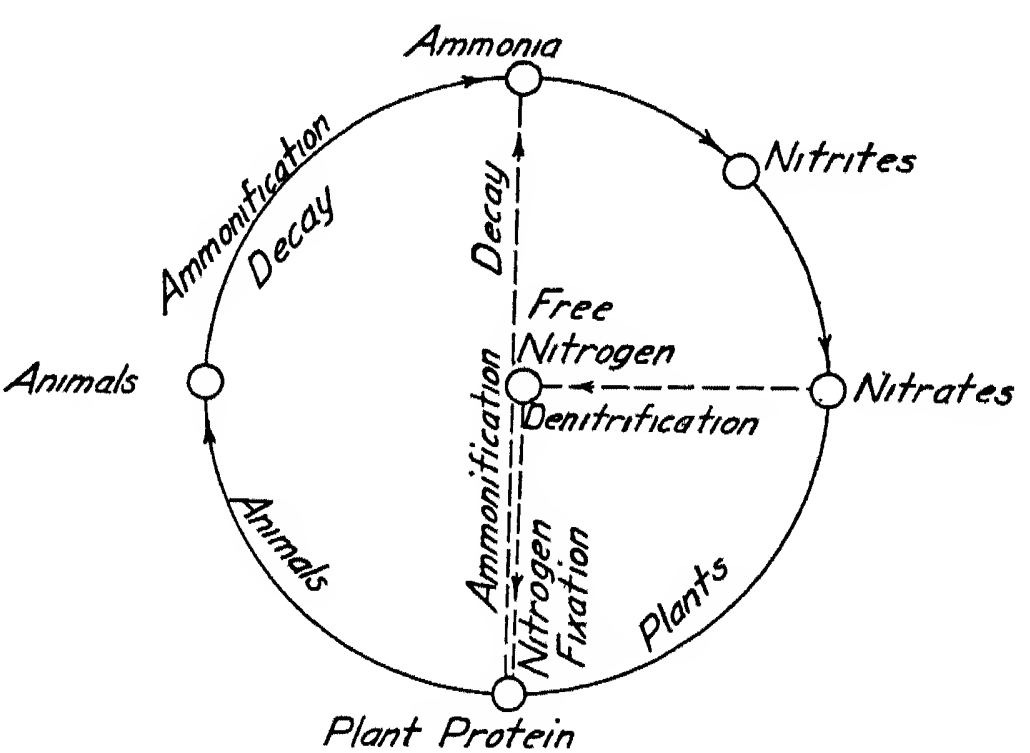

FIG. 25.-Illustrating nitrogen cycle in nature.

War enough nitrogen was liberated to produce the food of the civilized world for a year. Hence the combined nitrogen would continue to grow smaller were it not that other factors are at work in nature causing them to combine. Every flash of lightning causes some nitrogen to combine as oxides, but the quantity of combined nitrogen thus produced is relatively insignificant. The major factors are biological. There are within the soil two great groups of bacteria which possess the power of fixing nitrogen. The first-the non-symbiotic nitrogen-fixing organisms living free in the soil-are able, with the energy they obtain from the oxidation of organic carbon, to build up complex organic nitrogen compounds. There are two groups of these organisms-the aerobic and the anaerobic, the first being the more important. The other class of nitrogen fixers is the symbiotic. These live in conjunction with legumes and obtain from them carbonaceous material, and in return give combined nitrogen. In 
either case the combined nitrogen becomes available for higher plants. Then it again starts on its journey through the living and the dead.

The Sulfur Cycle.-Sulfur is an essential element for all plants and animals, but the quantity required for normal growth and development is relatively small even when compared with the small percentage found in soil. It occurs in the soil as organic and inorganic sulfur. The former is derived from the plant and animal residues. These are acted upon by microörganisms with the liberation of hydrogen sulfide, sulfur dioxid, and sulfates. Some of the hydrogen sulfide is carried into the ocean or soil by the first rain; some of it reacts upon the iron silicates of the soil and forms pyrite or marcasite, but most of it is oxidized by bacteria with the formation of sulfates. The sulfur dioxid is also further oxidized to sulfates, when they are again taken up by plants and start anew upon their wonderful journey through bacteria, higher plants, and animals.

The Phosphorus Cycle.-Phosphorus occurs in the soil in the form of calcium, aluminum, and iron phosphate, also as organic phosphorus. It is also found in places as huge deposits of rock phosphate. It is an integral part of every living plant and animal cell. In these it occurs in two forms-organic and inorganic. The organic phosphorus occurs in the nucleo-proteins, phosphoproteins, and phospholipins.

The mineral phosphates of the soil are rendered soluble through bacterial activity, as outlined previously. This is taken up by the living plant and deposited either as organic or inorganic phosphorus compounds within the plant tissues. The plant tissues, if eaten by animals, yield phosphorus to the animal to be laid down in the body of the animal as organic or inorganic compounds. The excreta of animals always contain phosphorus in both organic and inorganic forms. The inorganic phosphorus is readily utilized by plants and again starts on its cycle. However, the organic and animal residues must be mineralized by bacteria before they can be utilized again by plants. Microörganisms split off the carbonaceous material and the phosphorus is liberated mainly in the 
form of phosphates. Under some conditions mold action may give rise to small quantities of phosphin which must be again oxidized before being available to higher plants. In either event, the resulting phosphate is now ready to start on its cyclic journey through the plant and animal organism. This is dramatically outlined for a phosphorus atom by one writer as follows:

"Where was I born? Ah, that I cannot tell you. It was far, far, away from here, deep in the endless abyss of space, at an epoch so distant that even the earth on which you live had not been formed as yet; not even the great sun, now blazing in his glory, nor any of the innumerable multitudes of stars of the great universe now shining in the sky, had as yet come into being. No, they were mere cold whiffs of invisible vapor, scattered over all space, remnants of worlds vanished aeons before this great universe began. Out of the vast I came, born into that great sea of Ether which stretches unbroken from star to star through all the endless depths of space. Some vast change, some murmuring and stirring of gigantic forces in its bosom, forces scarce known, scarce dreamt of, but working there in irresistible might, first brought me into being, and I hung suspended in the great void. It was utterly cold and utterly dark, and gleaming afar in the distance I could see the myriad fires of the great worlds and suns of space shining at me through the darkness. How long I hung in the void I know not. It was millions upon millions of years. Then atoms began to gather round me, streamwise, coming from afar in phosphorescing torrents, and I perceived that I already formed part of a mighty mass of gas, a huge nebula, which stretched its gigantic arms out for millions of miles, like vast flaming swords, through the darkness of space. And so I hung for aeons of ages, while atom after atom in an endless stream flashed past me in the gloom, while the great nebula slowly drew together in its glory, and began to take shape and form. Then the temperature began to rise in leaps and bounds. It grew stifling hot, and great lightnings flashed and quivered about me, and we atoms crowded more and more together, colliding, whirling, flying. Each second I smote a thousand million atoms and at each 
collision my motion grew more and more violent, until after millions upon millions of years of this tumult, I found myself part of an immensely hot flaming mass of gas, part of an embryo sun. There in the whirl and roar of the elemental flame I remained for unthinkable ages, but at last vast thunders beneath and around me made me aware that something tremendous was happening. It was a world-my first world-gradually condensing out of the fire mist, and the gigantic explosions which occurred from time to time were just seas of boiling rock leaping upwards. I will spare you the account of how I entered into that world and saw it slowly form and develop into a fair planet covered with wonderful swarming masses of living creatures, with great cities filled with busy life, and wonderful civilizations. Nor will I tell you of how that world grew old, and passed into a vast desert, and finally, after wandering for aeons of ages in darkness and silence, burst suddenly forth into flame, the victim of a great cosmical catastrophe, and like a bubble, vanished, exploding into incandescent gas. Nor will I tell you of how, far flung, I fell upon another world, and saw this world too in time perish; and of how I passed from world to world, and formed part of world after world, wandering in mighty migrations through space, until at last I joined the fire mist from out of which, ultimately, this world of yours condensed amidst titanic convulsions. You will, therefore, see that even before your world began I was old, immensely old. I will pass over all this and come to a time quite recent, when I found myself forming part of the molten fire underground. Here I lay for age after age, while the land above me was being eaten away by wind and rain and storm, and was hurried-continent after continent crumbling into ruin-into the great ocean waiting patiently to receive it. Now I was urged upwards by vast forces, slowly, steadily, for thousands of years until I finally was uplifted to form part of a hard, cold rock, which soon reared itself into a mighty cliff, beaten upon by wind and rain and storm. I have a dim recollection of looking out from the cliff face upon a widespread blue sea filled with strange vast monsters which have long since vanished from the earth. 
But at last the cliff was washed away and I passed into the great body of the sea and was absorbed into a tiny plant, living beneath the salt waters; but this was devoured by a glittering, gorgeous fish, and so I entered his body. Then this fish was devoured by a reptile, which creeping out of the water, entered a swamp and died, and its huge body decaying I was washed into the soil, and there meeting with the rootlet of a plant $I$ entered into and formed a part of it; and this was eaten by an animal; and so I entered into its body and formed part of his bones. While we were crossing a ravine one bright sunshiny day, millions of years ago, a green monster flashed out upon us and slew my master and devoured me. After a time my new host was also slain in a similar manner, and his body, decaying in the rank grass and vegetation of the swamp, I was ultimately washed out to sea in a sudden flood, which, coming down from the hills, swept me away. Here I mingled with the mud at the bottom of the sea and stayed there for millions of years and became covered over with mighty layers of mud and sand and sank ever deeper and deeper into the earth, and at last once more I felt the glow of the nether fires. Here in the great gleaming furnaces of the deep I remained for many a million of years, while miles above me the world changed and developed, mountains came and went, new and strange creatures evolved, developed, filled all the earth, and died out again. One day, I was hurled forth amidst vast thunderings through the throat of a great volcano, and formed part of a molten lava stream, which in time became a fertile field covered with waving crops and golden grain. Then I entered into a grain of corn and was devoured by a man living thousands of years ago, a mere savage you would term him, wild and fierce. From him I passed to earth once more, and since then have been passing in a ceaseless round of change through the bodies of living creatures. I have flown through the air in a bird, I have swum in the sea in a fish, I have roamed over the earth in a beast, I have formed part of innumerable plants. But the full tale would only weary you, wonderful as it is. One day a few years ago I was devoured by an ox while forming part of a piece of grass, and soon by the 


\section{I06 BAC'TERIA ÁND SOIL FERTILITY}

mysterious chemical forces of its body I was made to form part of its bone. The great beast was slaughtered by men, and his flesh eaten, and his bones burnt to a fine white dust in a furnace. Out of this dust, I, the tiny phosphorus atom, was distilled in a furnace and found my way to a match factory and am now in this little match-box lying on the table before you. Is my journey finished? Oh dear no, far from it. I shall go on changing and journeying and dancing, age after age, even until the world fades away like a mist, and long after all that you see and hear around you has crumbled away and vanished into the awful maw of time. I have been taking part in the great dance of atoms which forms the basis of all passing things and events, for millions and millions of years to come. I may, indeed, see this world perish, and may yet dance in worlds as yet unborn. My future will be probably even more strange than my past." 


\section{CHAPTER XI}

\section{ORGANIC MATTER AND ITS TRANISFORMATION BY BACTERIA}

The great difference between a mass of finely ground rock and soil is that the latter contains intimately mixed with it varying quantities of organic matter. Although the quantity present in the soil is usually small, yet it is vitally important. The temperature, the structure, and the water-holding power are dependent upon the quantity and kind present. It determines the kind and speed of chemical reaction which occur. Last, but not least, it is the life of the soil, for it is in, and on it that bacteria work. They pull it to pieces, not in a haphazard but in a systematic manner. All the resulting blocks are sorted and arranged so they may be used again in the wonderful scheme of creation.

Quantity of Organic Matter.-A sandy soil may be devoid of organic matter, while a peaty soil may contain 90 per cent or over. Hence, the variation is wide, depending upon the plants and plant residues which come to the soil. Soils of warm, humid regions contain more than do soils of arid regions; pastures and grass lands contain more than cultivated. The methods of harvesting grains in the arid regions tend to leave large quantities of straw on the soil. And how important it is. But how does the farmer treat it? Is it plowed under to modify the physical, chemical, and biological properties of the soil? Or is it burned? When one sees the latter being done he feels like saying, as did one writer, "Watch a crowd of boys who are out for fun, and see if this fun is shared by the things they find-frogs or turtle, butterfly or bird, moth or beetle, flower or bee. . . . A boy and a dog are never so happy as when they start out together to kill something. The boy whistles and sings, the dog barks and prances. Neither one of them would be so overjoyed if he were 
going to save something. When the boy gets older he loses this primitive kind of destructiveness and uses a higher degree of more thoughtful intelligence by burning the forests and exhausting the soil."

The quantity which should be present varies with the soil and the use to which it is to be put. A safe rule is that there should be sufficient present to keep the soil in good physical condition and to liberate food as needed by the growing plant.

Kind of Organic Matter.-The kind of organic matter present may be even more important than the quantity. One soil containing 10 per cent of organic matter may be less productive than another with only 2 per cent. Hence, the kind and condition of the organic matter is important. It may be divided into three classes: (I) Active or fresh plant tissues which rapidly decay liberating their own plant-food and giving rise to acids which in turn liberate plant food from the mineral portion of the soil. From the viewpoint of the bacteriologist and that of fertility this form is most important. (2) The inert which is old and slow to decompose. The quantity of plant-food liberated from or by this in unit time is small and of ten insufficient to mete the needs of the growing plant. This form, together with the next or third form, constitutes the so-called humus. This is composed of a great variety of different compounds which have been produced through the decay of plants. Their composition varies with the original material from which they were derived and the conditions under which they were formed. They are probably of more value in modifying the physical properties of the soil than in the furnishing of actual plant-food. (3) This is the very resistant coal-like residue resulting from the action of bacteria, the atmosphere, and the soil, upon the original plant debris. It imparts to a soil its black color but probably has little value as plant-food.

Origin.-The origin of the organic matter of the soil is plant tissue, either that which has grown on the soil or has been carried to it by various agencies. That of the surface soil comes mainly from the leaves and stems, whereas the organic matter of the subsoil is the decayed and decaying roots of plants. The subsoils 
in some districts may contain organic matter which was carried in with the soil at the time of formation. For example, the Greenville (Utah) Experimental Farm which was deposited by water contains .53 per cent of humus in the first foot, nearly twice as much in the second, and .57 per cent in the tenth. However, the active organic matter of the surface is considerably higher than it is in the subsoil.

Composition.- The active organic material of the soil is composed of plant tissue which contains carbohydrates, fats, and proteins. The carbohydrates consist of the various sugars, starches, and celluloses or woody fiber. The protein may consist of any of the complex nitrogen-carrying compounds, whereas in the fats we find waxes, solid fats, and oils. Intimately mixed with all and often forming an integral part of the material are the essential plant-foods-phosphorus, potassium, and nitrogenin the form of organic and inorganic compounds.

The humus consists of a great variety of ill-defined chemical compounds. Among these we would expect to find, and do find, the building blocks of the proteins - the amino-acid. These, however, lose their ammonia; hence, there is a tendency for acid substances to accumulate, which if not neutralized by some base produce a sour soil. Not long ago it was believed that humus consisted mainly of ulmic and humic acids. We now know, however, that it is much more complex.

Function.-Organic matter has a very far-reaching influence upon the soil. It of ten determines whether a soil will be productive or barren. Some of the more pronounced influences are the following:

I. Organic matter in various stages of decay gives to a soil its dark-brown or black color. The absorption of heat and consequently the temperature depends to a large extent upon the color of the soil. It is common knowledge that dark-colored soils are earlier than light-colored soils. A very interesting demonstration of this can be made in the spring by filling a tray with lightcolored soil. Seeds are planted throughout and then one-half is covered with soot. In the soot-covered part plants come up in 
from twenty-four to seventy-two hours sooner than in the other parts of the tray. The temperature of the soil may be even 2 degrees higher in the colored portion than in the uncolored.

2. The decay of the organic manure in the soil generates heat. This may increase the temperature of the soil. Practical use is made of this in the preparation of the cold-frame for the forcing of young plants in the spring. The truck gardener also uses it when adding horse manure to his early truck gardens.

3. Organic matter changes the structure of the soils. When added to a tight or clayey soil, it tends to spread the particles, thus causing the soil to puff up. This increases the pore space and hence the quantity of oxygen entering. This accelerates beneficial bacterial activity. Partly decayed organic manures have a tendency to stick together; hence, when applied to a loose sandy soil they improve its tilth. The addition of large quantities of fresh organic manures may loosen up some soils to such an extent that they are injurious.

4. Organic matter acts like a sponge when brought in contact with water. Hence, when applied to a soil it increases its waterholding capacity. It also makes drainage possible in a tight soil.

5. It is the great reservoir in which is held the nitrogen of the soil as well as considerable phosphorus and potassium.

6. As the organic material of the soil decays there are produced various acids which act upon the insoluble plant-food of the soil and make it available. The more economic systems of maintaining soil fertility make use of this factor. The plantfood is added to the soil in the cheapest insoluble form and then rendered available as needed by the aeration of the soil, the addition of plant residues, and manure. It is the fresh organic manures and not the old decayed manures which are valuable in this respect.

7. The nitrogen-gathering bacteria of the soil must have energy in order to change the inert atmospheric nitrogen into compounds available to higher plants. This energy is obtained through the oxidation of the organic matter of the soil.

Decay.-Plants and animals including man are permitted to 
keep their bodies as long as they are useful, but just as soon as life becomes extinct they are dragged off to the bacterial bonfire so that the elements composing them can serve other plants and animals. How marvelous! Growing in water teeming with bacteria is a naked mass of protoplasm, an ameba, during life, it is not only unattacked by bacteria but actually feeds upon them. But let death come, and the ameba then serves as food for the bacteria. Growing in the soil are plants thriving upon the by-products produced by bacteria. Something happens, the plants die, and bacteria thrive upon them. From the moment of birth, man is surrounded by saprophytes. They are on the skin, in the secretions of the nose, mouth, and eyes, they fairly swarm in the alimentary tract, and probably do no harm; but let death come and nature's wrecking crew, the bacteria, become so active in pulling the body to pieces that if we are any distance from a friend at the time of death we must hasten to obtain even a last fond glimpse of the body of the dear one.

The speed with which decomposition proceeds varies with the nature of the original product and the microörganisms taking part. It is also modified by the presence or absence of air. When decomposed in the absence of air there are produced many ill-smelling products. This is usually spoken of as putrefaction. Where the organic matter is broken down by bacteria in the presence of air we refer to it as decay.

In the process of decay the carbon and hydrogen are liberated as carbon dioxid, methane, water, and other volatile products with the result that the carbon in the soil tends to fall off relatively to the nitrogen and the carbon-nitrogen ratio which in the original plant material is about 40 , is reduced in the soil to 10 . This carbon-nitrogen ratio varies with climatic conditions, also with soil type and previous treatment. Lawes and Gilbert give the following carbon-nitrogen ratio in the organic matter of different soils:

Cereal roots and stubble . . . . . . . . . 43.0

Leguminous stubble . . . . . . . . . . . 23.0

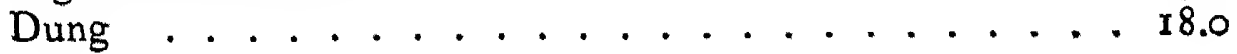


Very old grassland . . . . . . . . . . . . . . 13.7

Manitoba prairie soil . . . . . . . . . . 13.0

Pasture recently laid down . . . . . . . . . . II.7

Arable soil . . . . . . . . . . . . ro.I

Clay subsoil . . . . . . . . . . . . 6.0

Other things being equal, a wide carbon-nitrogen ratio indicates a more fertile soil than a narrow carbon-nitrogen ratio. However, this must always be interpreted with regard to the climatic conditions. In the arid regions the carbon-nitrogen ratio is narrow when compared with soils of the humid regions, yet the bacterial activity of the former is just as active as that of the latter.

The organic substances found within the soil are called humus and result from the action of bacteria upon the plant residues. The composition of this substance varies with the products from which it has been formed, also the degree of humification which has taken place and the specific microörganisms which have brought about the change. Moreover, the quantity and speed with which humus is formed depends upon the nature and condition of the material used and the physical, chemical, and biological conditions of the soil. Hilgard thinks that in the humid regions one part of normal soil humus may be produced from five to six parts of dry-plant debris, whereas in the arid regions from eighteen to twenty parts of the same material would be required. Snyder allowed various organic substances to humify for one year with the following results:

I part fresh cow manure yielded 33 parts humus containing $6.16 \%$ nitrogen I part green clover I part meat scraps I part sawdust 1 part oat straw yielded 25 parts humus containing $8.24 \%$ nitrogen yielded II parts humus containing $10.96 \%$ nitrogen yielded to parts humus containing $0.30 \%$ nitrogen yielded 6 parts humus containing $2.5 \%$ nitrogen

Humus is mainly valuable because of its physical effect upon the soil and on account of its nitrogen, potassium, and phosporus which are slowly liberated by bacteria. Its beneficial effect upon the bacterial flora of the soil and soil fertility, however, is mainly exerted before it reaches the stage of humus. 
Ammonification.-During the processes of decay the proteins are caused by the bacteria to take up water and albumoses result. These are caused to take up more water and in some mysterious way fall to pieces, and we have peptones. The process is repeated and there results amino-acid. The amino-acids are oxidized and ammonia results. Therefore, the production of ammonia by microörganisms is known as ammonification.

The speed with which it is produced in a soil is governed by the following factors: (I) the microörganisms which are bringing about this change, (2) the material to be ammonified and the nature of the soil, (3) moisture, (4) aeration, and (5) reaction.

Organisms Causing Ammonification.-Although it has been known for a long time that small quantities of ammonia occur in all arable soils, yet its formation was not known to be due to bacteria until I 893 when Müntz and Coudon demonstrated that ammonia is no longer produced in soil sterilized by heat. Following this, they and other workers tested many bacteria, yeasts, and molds and found that numerous organisms possess the power of producing ammonia. Some of the organisms are aerobic, other anaerobic. Both bacteria and molds possess the power to a high degree. A few of the more active organisms are $B$. mycoides, Sarcina lutea, $B$. subtilis, and Proteus vulgaris. One organism may act best on one substance and in one soil, whereas another organism may be at its maximum efficiency in an entirely different soil working on other material. As these organisms exist in soil probably there is a division of labor. One rapidly splits the complex proteins, others act on the albumoses, and still others act on the amino-acids. Then there are bacteria which quickly break down urea with the formation of ammonia. This may often be detected by its odor in a stable on a warm day. Although we thus find a great variation in activity and substance on which the ammonifiers act, yet they are all working in keeping with the general scheme of things, - the working over of old discarded material and rendering it suitable again to be used by plants and eventually by animals. The numbers in a soil vary, but probably from Io to 25 per cent of the soil flora are active ammonifiers. 


\section{II4 BACTERIA AND SOIL FERTILITY}

Material Ammonified.-Although all nitrogenous substances which reach the soil are broken down by bacteria and usually with the formation of ammonia, the speed with which this change occurs varies with the substance. Concentrated tankage, ground fish, and liquid cow manure are rapidly broken up with the liberation of ammonia, while the process with solid cow manure and cottonseed meal is slow. This is illustrated by the following results obtained by Lipman and his associates. The numbers represent the percentages of the total nitrogen of the various substances which were transformed into ammonia in six days.

Concentrated tankage . . . . . . . . . . 56.66 per cent Ground fish . . . . . . . . . . . 47.16 per cent Cow manure, solid and liquid excreta . . . . . . 32.60 per cent Dried blood . . . . . . . . . . . . I6.74 per cent Bonemeal ............. . . I6.65 per cent Cow manure, solid excreta . . . . . . . . . 5.39 per cent Cottonseed meal . . . . . . . . . . . . 4.95 per cent

The loss of the liquid portion of cow manure makes of it a slowly decomposing manure. This difference in ammonification in different manures accounts for the generally understood fact among gardeners that horse manure is a rapid decomposer and forces plants, whereas cow manure is much slower. The addition of manure to a soil greatly increases the ammonia produced in a soil. This is illustrated by the following results obtained by the senior author. In the first column is given the per cent of ammonia found. The untreated soil is taken as 100 per cent. The various quantities of manure were applied to the soil in pots and after four months the ammonifying powers determined. In the second and third column are given the results from actual field soils receiving each year the designated quantity of manure.

\begin{tabular}{l|c|c|c}
\hline \hline \multirow{2}{*}{ Treatment } & $\begin{array}{c}\text { Pot } \\
\text { Experiment }\end{array}$ & \multicolumn{2}{|c}{ Field Experiment } \\
\cline { 2 - 3 } & Fallow & Cropped \\
\hline No manure & I00 & I00 & 100 \\
5 tons manure & I22 & I47 & 120 \\
10 tons manure & I52 & I88 & 183 \\
I5 tons manure & I60 & & \\
20 tons manure & 180 & & \\
25 tons manure & & & \\
\hline
\end{tabular}


It is interesting to note that fallow soil has a much higher ammonifying power than has cropped, and this helps to account for the good results obtained by fallowing in the arid regions.

The speed with which proteins are ammonified varies also with the soil. A rich sandy soil supplied with optimum moisture may ammonify many times as fast as depleted soil or even a rich, tight, clay soil.

Moisture.-Ammonifying bacteria are similar to all other plants in that they must have water in order to function. Their activity increases as the moisure content of the soil increases until a certain moisture content is reached. Above this concentration there is a sharp drop in the ammonia production. This is at its maximum in a soil when the moisture is 60 per cent of the soil's water-holding capacity. This is one of the reasons why practical farmers find that crop yields are best when the soil is kept moist but not wet.

Aeration.-The first stages of the breaking down of the protein is due to the microörganism causing water to enter into the compound and then in some mysterious way to fall to pieces. In the last stages, however, when ammonia is split off oxygen enters. Hence, we find that aeration increases ammonification. We find ammonification rapid in fallow and the hoed crops as corn and potatoes, but slow in oat and alfalfa soil.

Reaction.-Acid soils ammonify slowly. Probably the small amount produced is due mainly to molds. Either limestone or lime added to such a soil accelerates the speed with which ammonia is produced. Limestone soil usually ammonifies rapidly.

Food Requirements.-The ammonifying bacteria break down the proteins with the formation of ammonia in order to get the energy necessary in their life processes. In addition to energy they must also have certain elements which are essential to plant growth. Phosphorus is required in large quantities by these organisms, and a soil having large quantities of available phosphorus, provided other conditions are ideal, has an active ammonifying flora.

The addition of starches, sugars, and other carbohydrates to a 
soil decreases the ammonia in it. This is probably due to two factors: (I) The decay organisms turn to the carbohydrates for their energy and lcave the protein intact. (2) Large quantities of carbohydrates in a soil favor the growth of microörganisms

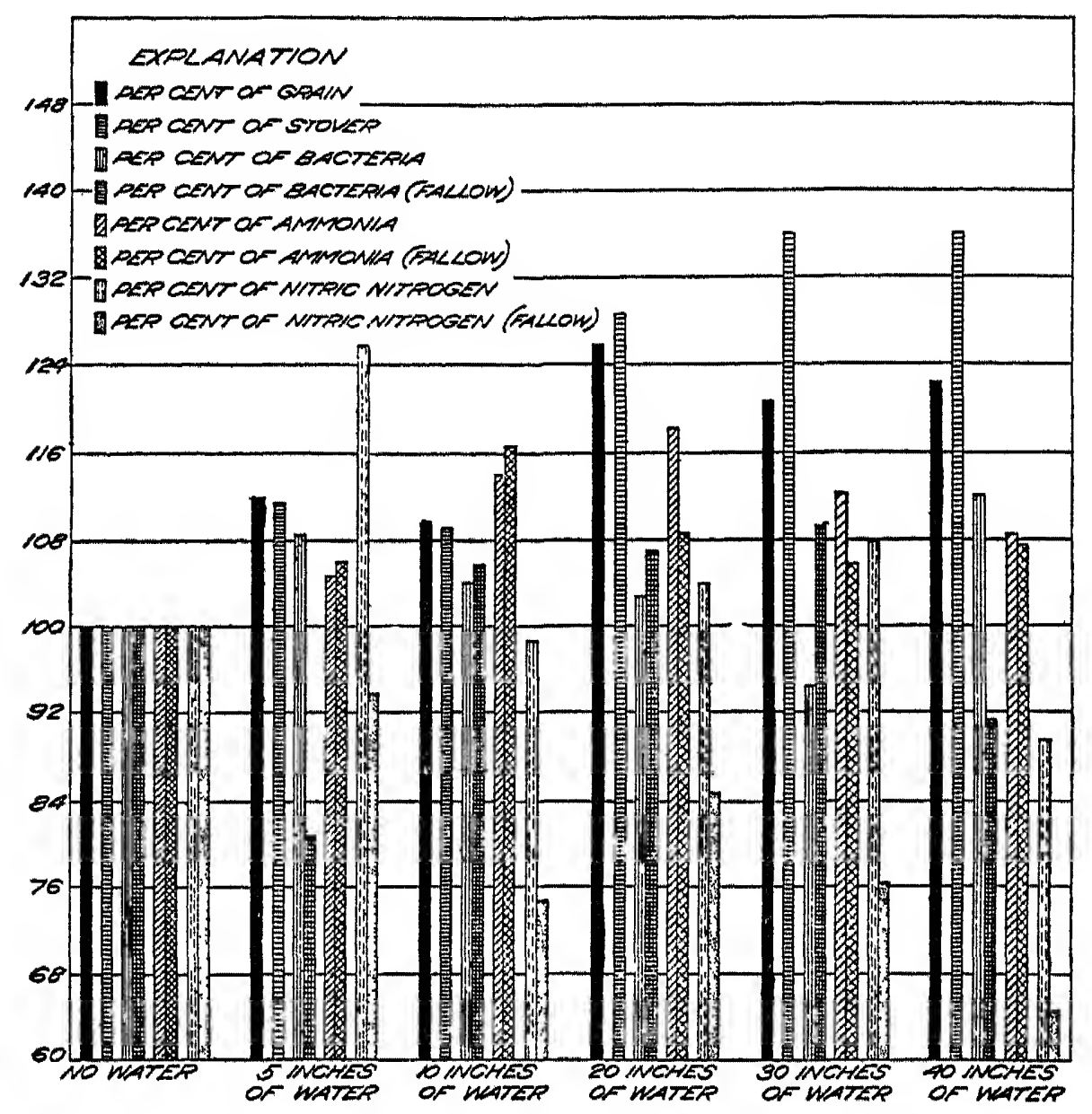

Frg. 26.-Illustrating the relationship between bacterial activities in a soil and crop yield.

which feed upon ammonia and transpose it into a protein. Hence, we may have in a soil to which carbohydrates have been added the bacteria competing with the higher plants for the limited supply of food. This at times results in a decreased yield.

Importance of Process.-We have seen that ammonification is a process by which the complex compounds are changed into simple. Now, higher plants cannot feed on fish, meat, or manure, but when these are changed into nitrates they become excellent 
sources of plant-food. The process of ammonification then is one step in the formation of available plant-food. Therefore, anything which will accelerate it during the growth of the plant is beneficial, whereas anything which retards it is detrimental.

Moreover, anything which would accelerate it during the wet seasons when the plants are not on the soil is injurious, because as the nitrogen changes into ammonia, and especially when transformed into nitrates, it is soluble and can be leached from the soil.

Since the process is beneficial, we would naturally expect to find a relationship existing between the soil and the crop produced upon such a soil. This is brought out in Figure 26.

Other workers have observed a similar relationship between ammonifying powers and productivity of a soil. There are individual cases in which this relationship breaks down as ammonification is only one step in the complex process of nitrate formation. The quantity of ammonia in a good arable soil is about four pounds per acre-foot. Occasionally ten times this amount may be found in pasture or heavily manured soil. In special cases even larger quantities may occur, but then abnormal plant growth occurs.

For these reasons the quantity of nitrates produced in a normal soil in unit time is a much better index of the crop-producing power of the soil than is the ammonifying power. Whereas in an alkali soil the production of ammonia is a better criterion of crop production than is the production of nitrates. 


\section{CHAPTER XII}

\section{NITRIFICATION}

Specialization in all fields of modern endeavor is the keynote of efficiency. Yet long before conceived of by man it had reached a high degree of perfection among the bacteria. Some bacteria hydrolize proteins; possibly others are more efficient in oxidizing amino-acids with the formation of ammonia; still others produce ammonia from urea. Specialization among the miscroscopic plants, however, reaches its highest state of perfection in nitrification. One class of bacteria seize upon the ammonia as produced and quietly but efficiently transform it into nitrous acid, whereas a still different group oxidizes the nitrous acid in to nitric acid. Hence, nitrification is the oxidation of ammonia into nitrous and then into nitric acid.

It is sometimes used in a broader although less scientific sense to designate the transformation of organic nitrogen into nitrates. This latter use is broader and includes the work not only of the nitrifying bacteria proper but also that of the ammonifying microörganisms.

How marvelous! Tiny plants producing powerful nitric acid! Why do they produce it? Is it for the same purpose that the stomach of man produces hydrochloric acid? What are the conditions under which it is produced and is it of economic value?

Earliest Development.-It is to the art of war and not peace that we owe much of our early knowledge concerning nitrification. Gunpowder is used in war. It made its first important appearance in Europe about the fourteenth century, and since the sixteenth it has played an all-important part in both war and peace. Gunpowder is a mixture of charcoal, sulfur, and saltpeter. Sulfur and charcoal are plentiful, but where shall the warring nations obtain their saltpeter? To meet this demand the govern- 
ments turned their attention to the development of the process of nitrification. Therefore, in the eighteenth century the artificial production of saltpeter in beds of decaying organic matter reached a high degree of perfection. Especially was this true in Sweden, Switzerland, and France where niter was collected as a part of each farmer's tax. In the year 1777 the French Government issued special instructions for the manufacture of saltpeter. In these there was given special attention as to the form of pit to be used, the covering of the organic matter, the arrangement for the free entry of air, the necessity of a mineral base, and the optimum amount of moisture which was best supplied from the drainage of stables.

Early Ideas.-Even though the process had reached such a high state of development, the underlying principles were entirely unknown until the last third of the nineteenth century. At this time attempts were made to explain the oxidation of ammonia to nitric acid, on the basis of certain chemical reactions which could be brought about in the laboratory. These were the experiment of Kuhlmann and Dumas. The first investigator found that on passing ammonia and air through a heated tube containing a platinum sponge that they combined with the formation of ammonium nitrate, while Dumas found that nitric acid was produced when air and ammonia were heated to $100^{\circ} \mathrm{C}$. with moistened lime. It was considered possible that the porosity of the soil could act as did the platinum sponge or the lime of the soil act in a manner similar to that used in Dumas' experiments. After the discovery of ozone by Schönbein this substance was used to explain all natural processes of oxidation, and hence naturally the case with nitrification. Mulder stated that investigations had shown that ozone is capable of oxidizing ammonia to nitric acid and water, and that it is probable that the same reaction could take place in the soil, the soil acting merely as a catalyzer in the reaction.

It may be seen that in all the early theories nitrification was supposed to be a purely chemical process; it was not until the time of Pasteur that the biological explanation for the formation of nitrates received any support. 
It is interesting, however, to note the careful work of Boussingault in the years between 1860 and 1878 on the natural-occurring saltpeter beds, especially those of Peru and Ecuador. He raised the question "have not the nitrates in the natural deposits resulted from the breaking down of organic substances rich in nitrogen," for it had long been the practice to use blood, urine, and other animal refuse for the production of nitrates. For this reason Boussingault did not think it likely that the gaseous nitrogen of the air played a very great part in the process of nitrification. In order to test this he placed soil with known nitrogen content in roo-liter jars and allowed them to remain for eleven years. At the end of this time they were analyzed, and, in spite of the fact that a very active nitrification had taken place, there was no increase in the total nitrogen of the soil. From this he concluded that free nitrogen takes no part in the formation of nitrates, but that they result from the organic matter of the soil. In another set of experiments he added organic manure to soil, sand, and chalk, and left them to nitrify. $\mathrm{He}$ obtained an active nitrification in the soil, but none in the sand or chalk. This fact had a great influence on the old theories of nitrification. Why this difference if the soil acts merely as a catalyzer?

The True Cause of Nitrification.-The brilliant investigations of Pasteur during the second half of the nineteenth century on fermentation prepared the way for the true understanding of the process of nitrification. In reality he actually expressed the belief that nitrification was due to a ferment. The proof of this was furnished in 1877 by two French chemists, Schlösing and Müntz. They were trying to ascertain if the presence of humus is essential in the purification of sewage by soil. They filled glass tubes one meter long with ignited sand and powdered limestone. Sewage passed through this filter at first unchanged, but later nitrates began to appear, and soon the filtrate contained no ammonium salts but an equivalent quantity of nitrate. They suspected microörganisms as being the active agents, and hence treated the contents with chloroform vapor. Nitrification entirely 
ceased and the ammonia in the sewage passed through unchanged. A water extract of fresh garden soil added to the tube soon restarted the process.

'This was confirmed by Warington, who further found that the oxidation of ammonia occurs in two distinct stages. 'The first stage involves the changing of ammonia to nitrates, the second of changing the nitrites to nitrates. Only after many years of study was he even able to obtain very active impure cultures of the organism which changes nitrites to nitrates, and although he observed other organisms which change nitrites to nitrates he was unable to obtain them in pure culture.

In 1890 a Russian investigator, Winogradski, by a series of very ingenious experiments isolated the organisms which transform ammonia into nitrites and the ones which transform nitrites into nitrates. He showed that the

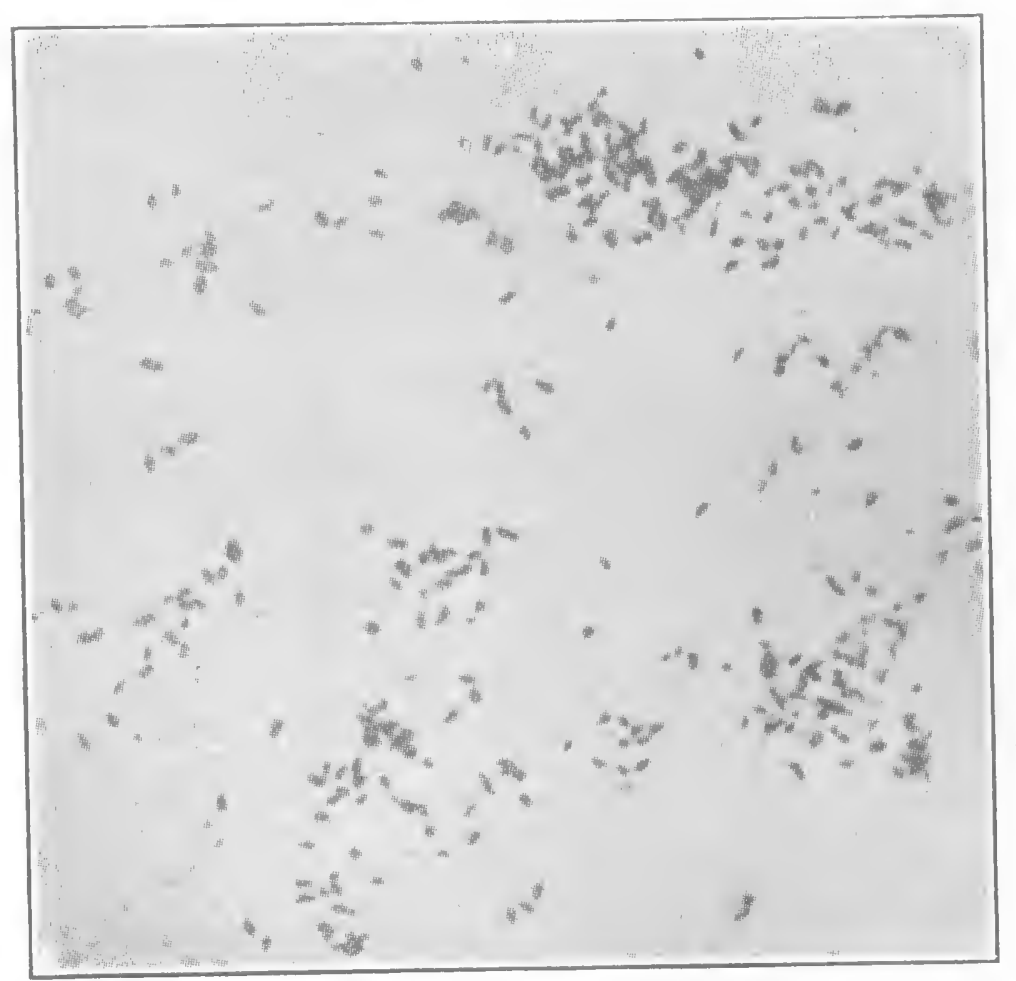

FIg. 28. - Nitrifying bacteria (nitrobacter) (after Gibbs).

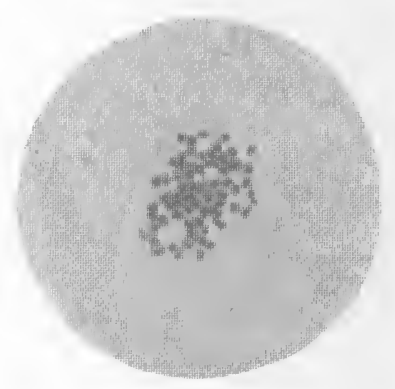

FIG. 27.-Nitrifyi $\mathrm{g}$ bacteria (nitrosococcus) (after Bonazzi). nitrifying organisms are sensitive to organic matter and hence do not develop on $\mathrm{th}$ e gelatin plates used in the study of the ordinary soil organisms. He grew them for som e time on cultural media containing only mineral salts. $\mathrm{He}$ then transferred $t h$ e $m$ to gelatin plates on which very $f$ e w colonies d e ve l- 
oped. Having learned that none of these were the bacteria he sought, he concluded that they must be on the surface of the media where inoculation had been made but no growth had appeared. He inoculated media from material picked up from these points and finally obtained the organisms he was seeking. Later Kühne used silica jelly in place of gelatin.

Winogradski found the nitrite bacteria to grow either as small oval, motile rods with polar flagella or in large non-motile globular form. He named them nitrosomonas and nitrococcus, respectively. Both possess the power of transforming ammonia only into nitrites. Those organisms which oxidize the nitrites to nitrates he designated nitrobacter. These are small non-motile rod-shaped organisms and transform the nitrites into nitrates as rapidly as they are produced, and it is only under abnormal conditions that ammonia or nitrites accumulate in a soil.

Distribution.-Probably the nitrifying bacteria were some of the first living organisms to appear upon this planet. They act even yet as the pioneers preparing the soil for other plant life. Müntz has found the decayed rocks of Alpine summits, where no other life exists, swarming with the nitrifying bacteria. The limestone and micaceous schists of the Pic du Midi, in the Pyrenees, and the decayed calcareous schists of the Faulhorn, in the Bernese Oberland, offer good examples of this kind. The organisms draw their nourishment from the nitrogen compounds brought down in snow and rain; they convert the ammonia into nitric acid, and this in turn corrodes the calcareous portions of the rock. Stützer and Hartleb have observed a similar decomposition of cement by nitrifying bacteria.

The nitrifying bacteria appear to be very widely distributed. Müntz and Aubin have observed their presence not only in all cultivated soils which they have examined but also in those of deserts. They are not usually found in the air or in rainwater. River water and sewage contain them. They are usually present in well waters. In the case of deep wells their origin is due to surface soil or drainage from the surface soil which has found its way into the well, the water of deep wells not being 
their natural habitat. Thomasen found the nitrite organism in samples of ooze from the bottom of the Kiel Fiord, but not in the sea water nor on the Plankton or the fixed algae. It was also found in similar samples of soil from the vicinity of Helgoland and in slime from the bottom of the Bay of Naples, but only in samples taken near the land. They are not found nor do they function in sea water.

Warington failed to find the nitrifying ferments in a clay soil below eighteen inches, and this is in keeping with the findings of Ladd at North Dakota. For a long time it was considered that they are found only in the surface soil, but in 1906 Welbel presented results with soils where nitrification is almost as active in the subsoil as in the surface soil when the subsoil is aërated. In I9I2 C. B. Lipman found them often to a depth of five or six feet in soils of the arid regions. In one case soil from the eight foot depth showed a vigorous nitrifying power. The Senior author found soil from second and third foot-sections to nitrify dried blood quite readily, as is shown on page I 24 .

These are the averages of several hundred examinations, and many soils were fairly heavy clays and showed active nitrification in the second and third foot-sections. This great difference observed in the arid regions is due mainly to a better aerration of these subsoils which, because of the peculiar climatic conditions, the arid soils are not as rich in clay as are the subsoils of the humid regions. Moreover, the plants in the arid regions root to a great depth in search of water. These decaying roots loosen up the subsoil and also furnish food for bacterial growth.

Factors Governing Nitrification.-The soil is the laboratory in which the tiny nitrifiers work. As a laboratory it must contain the material on which they are to work and also means by which the finished product, nitric acid, can be removed so it will not impede their activity. These organisms cannot produce something from nothing, nor can they increase one iota the total fertility in the soil. They can change only its form.

Manure.-The nitrifiers act upon ammonia and produce from 


\begin{tabular}{l|r|c}
\hline \hline & \multicolumn{2}{|c}{ Soil } \\
\cline { 2 - 3 } & Irrigated & Dry-farm \\
\hline First I2 inches & I9.39 & 5.25 \\
Second I2 inches & 2.70 & $2.4 \mathrm{I}$ \\
Third I2 inches & 1.98 & 1.55 \\
\hline
\end{tabular}

it nitrates; hence, they are dependent upon the ammonifying organisms for their supply of crude material on which to work, and this requires a supply of readily decomposable organic material. Hence, the addition of manure and plant residues to a soil increases its nitrifying powers. This is seen from the following results obtained at the Greenville (Logan) Experimental Farm:

\begin{tabular}{l|r|r}
\hline & Percent Nitrates Formed & Untreated Soil roo \\
\cline { 2 - 3 } & Fallow & Cropped \\
\hline No manure & 100 & 100 \\
5 tons manure & $1,21 \mathrm{I}$ & 453 \\
I 5 tons manure & 2,240 & 2,079 \\
\hline
\end{tabular}

Even when twenty-five tons of manure were applied to this soil excellent team work was done by the various classes of bacteria, so that the nitrogen eventually appeared as nitrates without any appreciable loss of nitrogen.

Oxygen.-In addition to ammonia on which to work there must be oxygen with which the ammonia can be transformed into nitrites, and eventually into nitrates. Hence, nitrification is best, other things being equal, in a well-aërated soil. This is illustrated by the work of Schlösing who exposed soil for four months to an atmosphere containing different percentages of oxygen. That which contained I.5 per cent of oxygen yielded $45.7 \mathrm{mg}$. of nitric nitrogen, that containing 6.0 per cent yielded 95.7 , that containing I I per cent yielded I $32.5 \mathrm{mg}$., whereas that containing 16.0 per cent of oxygen yielded $246.6 \mathrm{mg}$. of nitric nitrogen. 
Stirring and pulverizing the soil is therefore of great importance, as shown by the following. A number of pots were filled with soil. Part of them were allowed to stand undisturbed while the others were poured out upon the floor and frequently stirred. Those stirred invariably contained from ten to forty times as much nitrates as did the unstirred. Summer-fallowed land or land plowed in the fall contains more nitrates than cropped or unplowed soil. The difference at times is apparent thruout the following summer. Therefore when the farmer cultivates his soil he is in reality ventilating the laboratory of the nitrifiers, as they, like men and women work best in ventilated work shops.

Temperature.-The nitrifying bacteria are heat-loving and light-avoiding. Therefore, we are not surprised at King's results where he found that there was I. 26 times as much nitrates formed at $9^{\circ} \mathrm{C}$. as at $\mathrm{I}^{\circ} \mathrm{C} ., 2.76$ times as much at $20^{\circ}$, and 6.24 times as much at $35^{\circ}$ as at $\mathrm{I}^{\circ} \mathrm{C}$.

The significance of these figures is brought out more fully when we examine the amount of nitrogen appearing as nitrates in some cases. At $\mathrm{I}^{\circ} \mathrm{C}$. there were formed $\mathrm{I} 20$ pounds per acre; at $9^{\circ}, 150$ pounds per acre; at $20^{\circ}, 329$ pounds per acre; while at $35^{\circ}$ there were formed 747 pounds per acre. When we remember that the growing plant feeds on nitrates we are not surprised they grow rapidly in a warm sandy soil and slowly in a heavy cold clay. In the latter case the nitrifiers' laboratory is not sufficiently warm for efficient work.

Moisture.-Long before the process of nitrification was known to be due to microörganisms it was known that there must be a certain proportion of water in the medium in which nitrates were being formed. It was found that when small quantities of water were present the process was slow, and if too great an amount was present the nitrates disappeared completely. The quantity of water required for optimum nitrification varies with the soil, being higher for clay than for lighter soil. The Senior author, however, has found that nitrification is at its maximum in all 
soils when they contain about 60 per cent of the water which the soil will hold when saturated.

Work at the Utah Experiment Station demonstrated that the application of irrigation water to a soil has a distinctly beneficial effect upon nitrification. It is greatest where 15 inches of water were applied yearly. Under this condition the nitric nitrogen produced was 28.5 pounds per acre-foot of soil. The greatest benefit per inch of water was obtained when only 7.5 inches of water was applied. Excessive quantities of water retarded nitrification and leached the nitrates beyond the roots of the growing plants.

Food.-The nitrifying bacteria are similar to other plants in that they can live on inorganic salts. Even carbon dioxid suffices as their source of carbon. The green plants with few exceptions are the only other living organisms known to use carbon dioxid. These get the energy necessary to do this thru the action of their chlorophyll on sunlight. The fuel which the nitrifying ferments burn in their tiny engines is ammonia in the case of nitrosomonas and nitrites in the case of the nitrobacter. The ashes from this quiet but interesting combustion are nitrates. Workers have traced a definite relationship between the amount of ammonia oxidized and the carbon assimilated, as seen from the following:

\begin{tabular}{|c|c|c|c|c|}
\hline & \multicolumn{4}{|c|}{ Experiment } \\
\hline & $I$ & 2 & 3 & 4 \\
\hline Ammonia oxidized (expressed as nitrogen) & $\begin{array}{c}m g . \\
722.0\end{array}$ & $\begin{array}{c}m g . \\
506.1\end{array}$ & $\begin{array}{c}m g . \\
928.3\end{array}$ & $\begin{array}{l}m g . \\
8 \mathrm{I} 5.4\end{array}$ \\
\hline Carbon assimilated & 19.7 & I 5.2 & 26.4 & 22.4 \\
\hline Ratio-Nitrogen : Carbon & 36.6 & $33 \cdot 3$ & 35.2 & 36.4 \\
\hline
\end{tabular}

Hence 70 to 80 pounds of nitrogen are oxidized in soil by these organisms for every 2 pounds of carbon they assimilate.

When growing in solutions these organisms are injured by 
organic matter probably due to the poor aeration, however, when growing in the soil they are benefited by it.

Altho they produce acids they will not tolerate an acid medium. The nitrous acid as rapidly as formed is converted into a nitrite by the bases of the soil, whereas the nitric acid is quickly changed into a nitrate in which form it may accumulate. During this neutralization of the acids, some phosphorus, potassium, and other plant food is rendered available. The magnitude of this change varies with different soils. It is low in a calcareous soil and high in some containing only small quantities of carbonates. Inasmuch as acids inhibit the growth of these organisms we find their activities increased in acid soils when quicklime or limestone are added. Even large quantities of the latter may be present in a soil without interfering with nitrification, as we obtain rapid nitrification in the Greenville (Logan, Utah) Experimental Farm which contains about 40 per cent of calcium and magnesium carbonate.

Crop and Fallow.-Even as early as 1855 the work at Rothamsted had demonstrated that the beneficial effects of fallow lie in the increase brought about in the available nitrogen compounds of the soil. Deherain and Demoussy's work indicated that there is a larger production of nitrates in fallow than in cropped soils. In humid districts fallowing is of ten looked upon as an extreme form of soil robbery for it promotes the activity of soil organisms, and some workers have recorded a loss in fallow plats of 85.5 pounds per acre of nitrogen. This of ten exceeds the quantity removed by a crop. But these results do not hold in an arid climate nor during dry seasons, for here bare fallow may not necessitate this loss and much is to be gained by its practice.

Work carried on at the Utah Experiment Station and extending over a number of years showed that the fallow soil contains considerably more nitrates in the summer and fall than do most cropped soils. This gain is carried over into the next spring, and hence furnishes a ready supply of nitrogen for the growing plant. 
The average results for a number of years, stated as pounds per acre, of nitric nitrogen in the first six feet is given below.

\begin{tabular}{l|r|r|r}
\hline \multirow{2}{*}{ Crop } & \multicolumn{3}{|c}{ Season } \\
\cline { 2 - 4 } & Summer & Fall & Spring \\
\hline Alfalfa & I9.3 & 39.2 & 44.9 \\
Oats & I0.4 & 23.3 & 42.1 \\
Corn & I 7.3 & 33.3 & 27.4 \\
Potatoes & II3.7 & 102.2 & 196.3 \\
Fallow & 72.8 & 106.9 & I43.0 \\
\hline
\end{tabular}

This fallow soil would contain about 100 pounds more available nitrogen in the spring than would the soil producing alfalfa, oats, or corn. Other soils may contain more or less than this amount, but usually where there has not been sufficient winter rains to wash the nitrates from the soil fallow contains more the next spring than similar cropped soil. At times this is due mainly to the season's accumulation of nitrates and only occasionally to more rapid nitrification. Now, less water is required to produce a pound of dry matter on a rich soil than on a depleted soil. Moreover, rapid bacterial growth would mean the formation of large quantities of acid which in turn would liberate more phosphorus. 'Therefore, corps following fallow may have a better supply of both nitrogen and phosphorus, and a good supply of available phosphorus promotes root growth in the young plant. Both of these factors would greatly help the plant in resisting drought.

Moreover, Lipman found that wheat grown on soil well supplied with nitrates contains a higher protein content, and the protein content of the wheat grown on the soil of the arid west where summer fallowing is extensively practised is very high in protein.

We have further found that the average nitrifying powers of a cultivated soil is about twice that of adjoining virgin soil, and altho the nitrate content of alfalfa soil is low, yet it promotes 
nitrification, and this is perceptible even into the second year after the alfalfa has been plowed under. Hence, we can conclude that alfalfa not only feeds closer upon the soluble nitrates of the soil but also makes much greater drain upon the insoluble nitrogen of the soil by increasing its nitrifying powers.

Loss of Nitrates.-The loss of nitrates from a soil may be either great or small, depending on a number of factors, the more important of which are as follows:

(I) The rapidity of nitrification. Nitric nitrogen may be produced in some soils so rapidly that even luxuriant vegetation will not remove it as fast as formed, whereas in another soil it may be formed so slowly that it will not suffice for even meager growth. The loss in the first case may be very large, while that of the second would be nearly zero.

(2) The nature of the soil. A tight soil, other things being equal, would retain the nitric nitrogen to a greater extent than would a loose porous soil, and a deep soil more than a shallow soil.

(3) The amount and distribution of rainfall. All other conditions being equal, thirty inches of precipitation thruout the year, would remove more nitric nitrogen from the soil than would fifteen inches similarly distributed. But if the fifteen inches came within a short period, while the thirty was distributed thruout the year, the fifteen inches of rainfall under these conditions may remove more nitric nitrogen from the soil than would the thirty.

(4) The rapidity with which the nitric nitrogen is removed by the growing crop. Alfalfa, oats, and wheat are heavy feeders upon nitric nitrogen and in most soils remove it as fast as formed. Hence, little is left to be washed out by the drainage. Moreover, crops such as these rapidly remove the water from the soil and hence diminish the drainage from such soils. Moreover, crops growing during the rainy season tend to conserve the nitric nitrogen where fallow soils rapidly lose nitric nitrogen during this period.

(5) The rapidity with which nitric nitrogen is transformed into protein nitrogen by soil microörganisms. It is now known that there are within the soil many microörganisms which trans- 
form nitric nitrogen into protein nitrogen and the speed with which this change occurs may at times become important, that is, work at the Utah Experiment Station indicates that this may at times reach twenty or thirty pounds per acre yearly.

Nitrogen in Drainage Waters. Rothamsted Experiments Average of 12 Years (Or More)

\begin{tabular}{|c|c|c|c|c|c|}
\hline \multirow{3}{*}{ Month } & \multirow{3}{*}{$\begin{array}{c}\text { Rainfall } \\
\text { (in.) }\end{array}$} & \multicolumn{3}{|c|}{ Bare Soil-6o-inch Gauge } & \multirow{3}{*}{$\begin{array}{l}\text { Wheat Land } \\
\text { Nitrogen } \\
\begin{array}{c}\text { Per Million } \\
\text { of water }\end{array}\end{array}$} \\
\hline & & \multirow{2}{*}{$\begin{array}{c}\text { Drainage } \\
\text { (in.) }\end{array}$} & \multicolumn{2}{|c|}{ Nitrogen } & \\
\hline & & & $\begin{array}{c}\text { Per Million } \\
\text { of water }\end{array}$ & $\begin{array}{c}\text { Pounds Per } \\
\text { Acre }\end{array}$ & \\
\hline January & 2.13 & I.93 & 8.9 & 3.88 & 3.1 \\
\hline February & 2.16 & 1.74 & $9 . I$ & 3.57 & 4.0 \\
\hline March & 1.70 & .94 & 8.9 & 1.89 & 2.0 \\
\hline April & 2.25 & .79 & 9.0 & $1.6 \mathrm{I}$ & I. 9 \\
\hline May & 2.48 & .79 & 9.1 & 1.63 & .9 \\
\hline June & 2.59 & .78 & $9 . I$ & 1.60 &. $\mathrm{I}$ \\
\hline July & 2.85 & .62 & I I. 8 & I.66 &. $\mathrm{I}$ \\
\hline August & 2.69 & .76 & $13 \cdot 3$ & 2.28 &.$I$ \\
\hline September & 2.70 & .82 & 13.4 & 2.50 & 3.9 \\
\hline October & 3.12 & I. 68 & II.9 & 4.53 & 4.6 \\
\hline November & 3.20 & $2.3^{2}$ & II. 4 & 5.98 & 3.6 \\
\hline December & 2.34 & I. 88 & 10.6 & $4.5^{I}$ & 4.8 \\
\hline January-April & 8.24 & $5 \cdot 40$ & 9.0 & 10.95 & 2.8 \\
\hline May-August & $10.6 \mathrm{I}$ & 2.95 & I0.6 & 7.17 & $\cdot 3$ \\
\hline September- & & & & & \\
\hline December & II. 36 & 6.70 & II. 8 & $17.5^{2}$ & 4.2 \\
\hline $\begin{array}{l}\text { January- } \\
\text { December }\end{array}$ & & & & & \\
\hline December & 30.21 & I 5.05 & 10.5 & 35.64 & 2.4 \\
\hline
\end{tabular}

These factors must always be kept in mind in an attempt to reach general conclusions from any special cases, yet it is instructive to examine a few results from the Rothamsted Experiment Station, as compiled by Dr. Hopkins.

It does not necessarily follow that all of the nitric nitrogen 
which is carried to a depth of 60 inches is lost to the growing plant, for in work at the Utah Experiment Station the Senior author and co-workers have found in the spring a nitrate belt as low as the seventh and eighth foot-section. These nitrates had been carried to this depth by the winter and spring water. It was noted that later in the season as the water was brought to the surface by capillarity the nitrates also returned, and by June, July or August, depending upon the crop grown upon the soil and the quantity of irrigation water applied, the nitrate belt which in the spring was in the seventh and eighth foot-section had reached the surface foot-section. Moreover, the deep-rooted plants of the arid regions probably feed from lower depths than do the shallow-rooted plants of the humid regions.

The practical conclusion to be reached from these results is that the method of reducing the loss by leaching is by growing plants, the roots of which may absorb the plant-food as rapidly as it is made available.

The loss of nitric nitrogen from irrigated soil may be prevented by the judicious use of irrigation water. Experiments at the Utah Station, covering a period of fourteen years, have demonstrated that the application of 15 or 20 inches of irrigation water, distributed thruout the season, to deep soil causes little, if any, loss of nitric nitrogen from such a soil, whereas applications of from 25 to 37.5 inches similarly distributed cause considerable dimunition in the crop yield. This decrease in crop yield due to excessive quantities of water, up until the soil becomes water-logged, is largely due to the rapid washing of the nitric nitrogen beyond the feeding area of the plant roots. 


\section{CHAPTER XIII}

\section{DENITRIFICATION}

It has been known for a long time that under certain conditions more of the nitrates disappear from the soil than are taken up by the growing plant. As was shown in the preceding chapter, much of this loss can be accounted for in the drainage water. Occasionally there are still other losses. These have been attributed to various factors: (I) Elementary nitrogen may be liberated from the protein during the process of decay; (2) the nitrates or ammonia may be reduced with the production of gaseous nitrogen; (3) The nitrates may be transformed into nitrites, ammonia, or proteins within the soil. The first two processes actually deplete the soil of its total nitrogen, and if it occurred to an appreciable extent in normal soils would have considerable economic significance. The third process merely changes the form of the nitrogen of the soil without decreasing its total nitrogen content and may be harmful or beneficial, depending upon conditions. If transformed by bacteria into proteins when needed by the growing plant we would have these minute specks of living protoplasm competing with and retarding the growing crop. The nitrogen may become available to later crops. If the nitrates, when the soil is bare, are converted into proteins by bacteria they are less likely to be leached from the soil. Under this condition the disappearance of nitrates from the soil would be a benefit. On the other hand, where the nitrates are reduced to free nitrogen this is lost completely from the soil.

The reduction of nitrates to nitrites or ammonia can be referred to as partial denitrification, whereas the liberation of nitrogen as a gas from either nitrites or nitrates is true denitrification.

Why This Loss?--Early answers given to this question assumed that the loss is due to chemical changes. Possibly the or- 
ganic matter of the soil on coming in contact with nitrates was oxidized and the nitrogen liberated. It was well-known that under certain conditions nitrites and ammonia would react and both lose their nitrogen. Could this be what was happening in the soil? This question was answered in 1886 by Gayon and Depetit who isolated from the soil two organisms- $B$. denitrificicans $\alpha$ and $\beta$-capable of acting on nitrates with the evolution of gaseous nitrogen. They also found a number of organisms capable of reducing nitrates to nitrites.

Organic substances, such as straw, carry the denitrifying bacteria. They are carried with the litter to the manure and later with the manure to the soil. The true denitrifiers are less prevalent in cultivated soil, but the ones which yield nitrites or protein are more numerous as has been demonstrated by the work of Putnam. He examined 201 species and found I 39 capable of reducing nitrates to nitrites, whereas none liberated nitrogen. Even in manure those which affect partial denitrification are most numerous. Severin studied twenty-nine different microörganisms from horse manure. Of this number eight were capable of complete reduction of nitrates, provided the nitrate concentration be not too great. Nine of the remaining were able to reduce nitrates to nitrites.

Loss of Nitrates from Manure and Soil.-The finding of the denitrifying bacteria on straw and in manure, together with the established fact that they can under appropriate conditions decompose nitrates with the evolution of gaseous nitrogen, led Wagner in 1895 to emphatically declare that the application of cow or horse manure to a soil is often not only unprofitable but harmful, that when applied together with nitrates they cause, by virtue of the microörganisms contained in them, the destruction of the nitrates. More than that, the baneful effects do not stop here, for the nitrates as they are gradually formed from the organic matter of the soil are also attacked by the denitrifying bacteria and their nitrogen set free. In reality, then, the animal manures applied are not only useless in themselves but are harmful because of their destructive effects on the oxidized nitrogen derived from other sources. 


\section{34}

BACTERIA AND SOIL FERTILITY

These conclusions were criticized by Warington who pointed out that they were based on experiments in which the dressing of dung was enormous and the same would not occur under ordinary practice. This led to extensive experiments in many parts of the world. The conclusions of this work can thus be summarized:

I. The losses of ammonia from manure are comparatively slight, but the setting free of elementary nitrogen which is due to microörganisms and not chemical means may be considerable.

2. With a limited supply of air in manure, the loss of elementary nitrogen and of organic substance are not extensive, but the greater the access of air the greater the loss of nitrogen, in some cases becoming as great as 40 or 50 per cent.

3. Ordinary conservation materials, when applied in the usual quantities, do not stop entirely the loss of nitrogen, but burnt lime is quite effective in stopping denitrification. Solid excreta and straw lose their nitrogen very slowly and no conservation material is needed. It is only the nitrogen of urine which requires conservation.

It is sometimes found that the addition of large quantities of organic matter to a soil causes a decrease in crop yield. This is especially true with regard to the carbohydrates and it has often been interpreted as indicating rapid denitrification, but $P$ feiffer and Lemmermann have pointed out that there are at least three factors which play a part, namely, (I) direct injury to the growing plants by large quantities of organic matter, (2) fixation of soluble nitrogen by the increased activity of different organisms, and (3) denitrification proper.

It is quite probable that the last is of the least importance, for Voorhees and Lipman after ten years' investigations under carefully controlled conditions conclude that "at least with cow manure, used at the rate of sixteen tons per annum for a period of ten years, no destruction takes place. In view of the long duration of the experiment and of the comparatively large amounts of manure used in the course of the ten seasons, we must assume that denitrification is not a phenomenon of economic importance 
in general farming and under average field conditions. We have no hesitation in emphasizing again the view expressed abovethat under the wide range of field conditions, denitrification is not a phenomenon of economic significance to the general farmer."

Moreover, at Rothamsted a plot of ground one-thousandth of an acre in extent has been kept from vegetation by hoeing for thirty-five years. During this time it has lost one-third of its original stock of nitrogen, but all except I Io pounds of this is accounted for by the nitrates in the drainage water, as may be seen from the following:

\begin{tabular}{|c|c|c|c|c|c|c|}
\hline \multicolumn{2}{|c|}{$\begin{array}{l}\text { Nitrogen in } \\
\text { Soil }\end{array}$} & \multicolumn{3}{|c|}{$\begin{array}{c}\text { Nitrogen per Acre } \\
\text { (lbs.) }\end{array}$} & \multirow{2}{*}{$\begin{array}{c}\text { Nutrogen } \\
\text { Recovered } \\
\text { as Nitrates }\end{array}$} & \multirow[t]{2}{*}{$\begin{array}{c}\text { Nitrogen } \\
\text { Unaccounted } \\
\text { for }\end{array}$} \\
\hline 1870 & 1905 & 1870 & $r 905$ & $\begin{array}{l}\text { Loss from } \\
1870-1905\end{array}$ & & \\
\hline $.1_{4} 6$ & .102 & 3500 & $245^{\circ}$ & 1050 & 940 & IIO \\
\hline
\end{tabular}

Russell, commenting upon the results, states: "The experiment is not fine enough to justify any discussion of the missing I IO pounds, but it shows that the loss of nitrogen is mainly due to leaching out of the nitrates."

Factors Influencing Denitrification.-Denitrification can take place in a soil only when a source of carbon is present, nor is the form in which the carbon exists without significance. Denitrifiers need large quantities of organic food and develop best in the presence of the fresh plant and animal debris. Hence, it would be unwise to use heavy dressings of nitrate and fresh manure or to plow under with the nitrates green-manuring crops. Partly decayed barnyard or green manures do not appear to favor denitrification.

In very wet soils oxygen is excluded. Here the bacteria turn to the soil nitrates for oxygen and hence liberate the nitrogen. 
In well aerated soils this does not occur as the denitrifiers appear to be only facultative anaerobes.

The senior author failed to find any evidence of denitrification in a highly calcareous soil to which had been added from zero to twenty-five tons per acre of manure and from 12.5 per cent to 22.5 per cent of moisture as may be seen from the following:

\begin{tabular}{l|c|c}
\hline \multicolumn{1}{c|}{ Treatment } & $\begin{array}{c}\text { Nitric Nitrogen } \\
\text { (per cent })\end{array}$ & $\begin{array}{c}\text { Gain in total Nitrogen } \\
\text { (per cent) }\end{array}$ \\
\hline I2.5 per cent of water* & I00 & I00 \\
I5 per cent of water & I18 & I08 \\
I7.5 per cent of water & I2I & 102 \\
20 per cent of water & I2I & I04 \\
22.5 per cent of water & I23 & I08 \\
\hline
\end{tabular}

Therefore, denitrification may occur in a water-logged soil containing large quantities of fresh organic matter or in tightly packed soil, but it is doubtful if it is of any economic importance in normal soils.

Denitrifiers are mostly heat-loving microbes and hence have an optimum temperature relationship considerably higher than that which occurs in the average soil. The conditions, therefore, which promote denitrification are just the opposite of those which promote nitrification. Hence, the factors which the farmer has learned promote plant growth retard the growth of injurious bacteria.

Functions of Denitrifier.-When acting in the farmer's soil, the denitrifier is a robber bacteria lying in wait until the banquet has been prepared by the honest-toiling nitrifiers. Then the denitrifier slips in and wastes the precious plant-food. But from what has been said concerning its habits, we find this microbe a robber by force of circumstance imposed upon him by the farmer's injudicious handling of his soil: However, the denitrifier has a specific function in returning the huge quantities of nitro-

* The soil containing 12.5 per cent of water was taken as producing too per cent. 
gen which find their way in organic compounds iniu the septic tanks of large cities. Moreover, thousands of tons of organic nitrogen are carried by streams to lakes and oceans. The nitrogen of this must be returned to the atmosphere so as to start again on its wonderful journey of construction, or in the case of war destruction. How shall this be accomplished unless through the action of the denitrifiers. 


\section{CHAPTER XIV}

\section{NON-SYMBIOTIC NITROGEN FIXATION}

Native rocks are usually free from nitrogen. Soils produced by the grinding of them are poor in it. Therefore, in many respects nitrogen stands apart from the other elements. It is inert and does not readily enter into chemical compounds. Its natural home is the atmosphere to which it is always attempting to return. In all arable soils it is found in greater or less quantities. How did it get there? "The lightnings of a billion storms have combined it in the air; the rains of hundreds of millions of years have washed it combined from the air into the soil; billions upon billions of microbes in plants and in the soil have ceaselessly absorbed it during unnumbered ages; consequently, the nitrogen combined in our soil represents the united efforts of all Nature working continually for unthinkably vast periods of time.

"What do we do with the earth's precious store of nitrogen? We filch it from the soil immensely faster than it is restored by natural processes; and the land grows sick and barren and refuses to grow our crops. Vast tracts of land in Sicily, in the broad plains of North Africa, in the Great Valley of the Euphrates, once the richest corn-producing region of the world, have within historical times grown barren largely owing to this cause."

This condition was sensed to its fullest extent by Sir William Crooks when he made his famous address to the British Association in 1898 in which he predicted that the world in thirty or forty years from that date was doomed to suffer from a wheat famine unequalled in history if the men of science did not find a practical method of inducing the inert nitrogen of the air to enter into combination with oxygen and produce the nitrates essential for plant growth.

How successful science has been in meeting this dilemma is answered by the results portrayed in Figure 29. 
Moreover, synthetic nitrogen compounds not only compete with natural ammonia and nitrates in quantity but they are competing with them in price as well and have actually driven from the market the natural product. In Germany "one German electric firm with aid from the city of Berlin recently contracted to

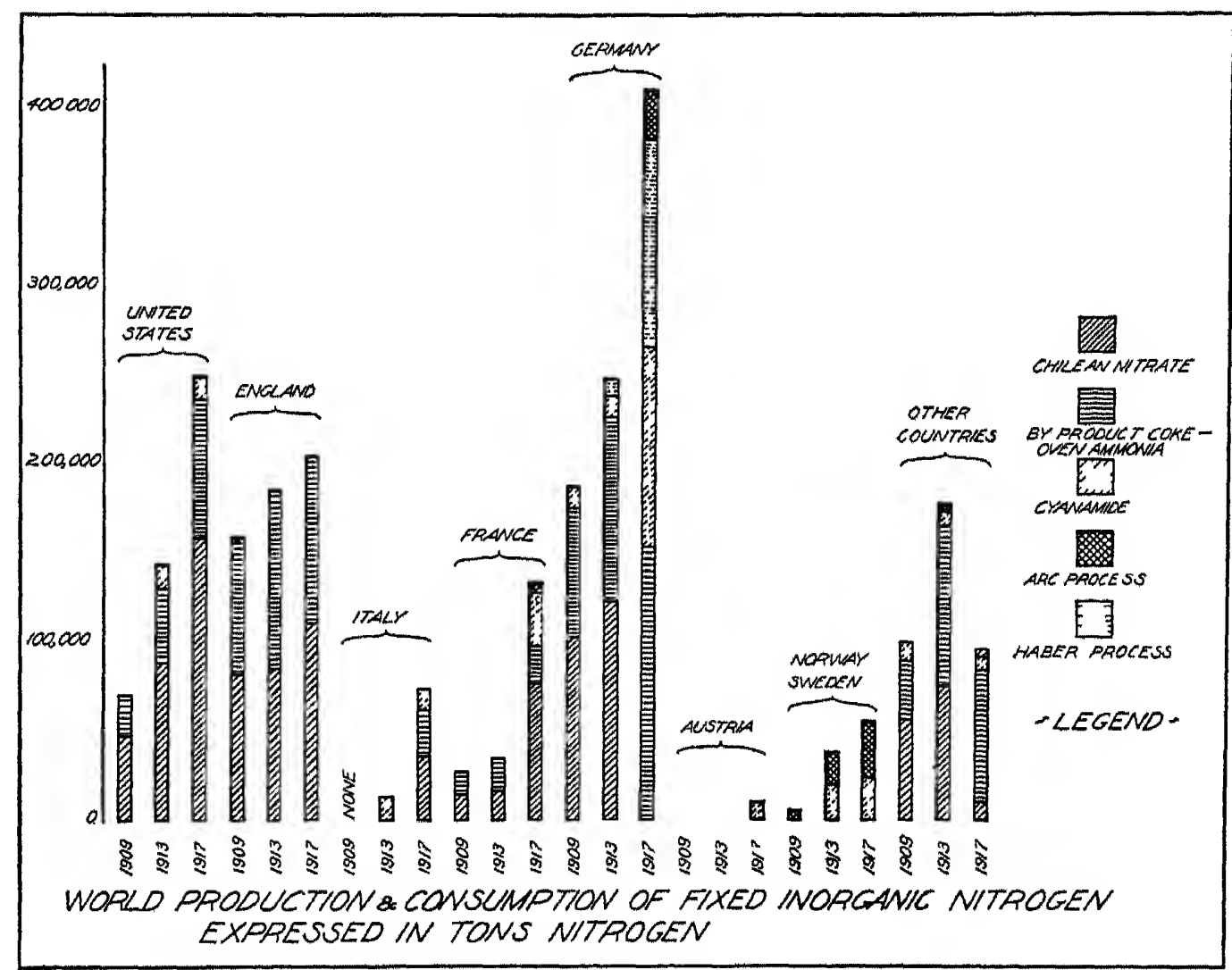

FiG. 29.-Nitrogen produced by various processes and then consumed.

provide $66,000,000$ pounds of fixed nitrogen a year at a cost of three cents a pound for the next twenty-five years."

The supply from this source at the present time is adequate, but such nitrogen usually costs the farmer about twenty cents a pound. At this rate the nitrogen in a bushel of wheat would cost thirty cents, in a ton of beets one dollar, and in a ton of alfalfa hay ten dollars. Is there no other source to which the farmer can turn? Virgin soil received its nitrogen from other sources, namely, the microscopic plants.

Development of Our Knowledge.-It has been known for 
generations that uncropped soils increase in fertility. Less ancient, however, is the knowledge that this increase may be due to a gain of nitrogen in the abandoned soils. Even more recent than this is the knowledge that it may be due to bacteriological action.

In the middle of the nineteenth century Boussingault wrote: "Vegetable earth contains living organisms-germs-the vitality of which is suspended by drying and reestablished under favorable conditions as to moisture and temperature." $\mathrm{He}$ also hinted at the fact that these microörganisms take part in the process of nitrogen fixation. It was not until thirty years later when Hellriegel and Wilfarth made their discovery of nitrogen fixation by symbiotic organisms. At that time the laboratory technique of modern bacteriology was still undeveloped. Since then, however, we have learned much concerning the relationship of plants to free and combined nitrogen of the air and of the soil. We know that soil gains in nitrogen are of ten due to microörganisms either living free in the soil or in company with the higher plants. The production of nitrogen compounds from atmospheric nitrogen by bacteria in the absence of higher plants is designated non-symbiotic nitrogen fixation or azofication. When fixation is accomplished by bacteria living in connection with and receiving benefit from higher plants it is called symbiotic nitrogen fixation.

As early as 1883 Berthelot undertook the study of soils with regard their relation to atmospheric and combined nitrogen, and as a result of these studies he was the first to definitely recognize that gains which occur in bare, unsterilized soils are due to microscopic plants.

Berthelot's discovery interested Winogradski who commenced work which eventually bridged the chasm. He employed, as a medium, a nutritive solution free from combined nitrogen but containing mineral salts and dextrose. Fifteen separate species of soil bacteria were isolated, but only one-a long spore-bearing bacillus which developed normally in the absence of combined nitrogen and seemed to produce butyric fermentation-fixed nitrogen in an appreciable degree. Quantitative tests showed 
that the maximum fixation was attained where no combined nitrogen was purposely added and that on the addition of such, fixation of nitrogen was diminished.

Following Winogradski, Caron made some very interesting discoveries. He found that soils under leafy crops contain greater numbers of bacteria than those under grasses. He also observed that the bacterial flora of soils in the spring is different from that in the fall both quantitatively and qualitatively. He used in vegetation experiments pure cultures of the bacteria most frequently encountered in natural soils. Some soils were inoculated with bouillon culture, whereas others received only sterile bouillon. The crop yields were usually in favor of the inoculated plots but showed variations from season to season. Exceptionally good results were ob-

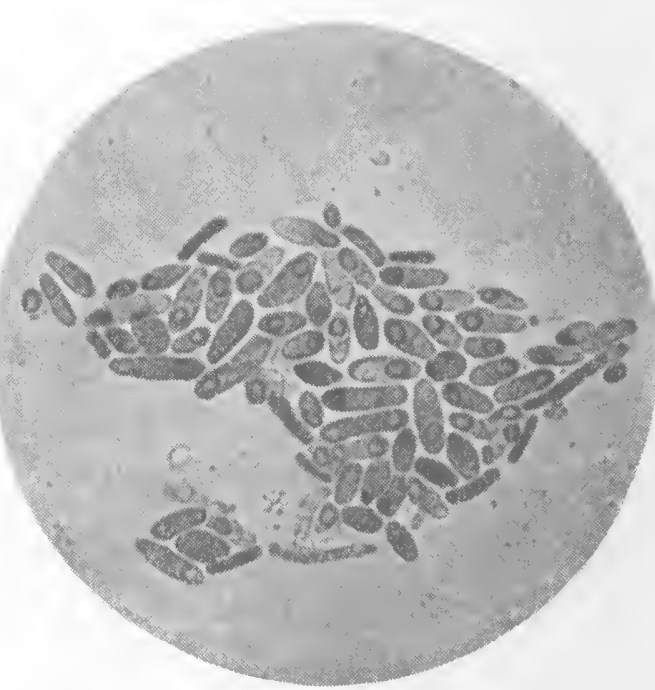

FIG. 30.-Clostridium pasteurianium (after Winogradski). tained with a spore-bearing bacillus which he termed Bacillus ellenbachensis.

Caron's work led to the commercial exploitation of his cultures, one of which, "alinit," was the subject of much study and discussion. This culture was found to contain, according to Severin, two closely related bacilli which he chose to designate as $B$. ellenbachensis $A$. and B. These had the power to fix nitrogen to some extent. Tests with "alinit," however, have not confirmed to any great extent the claim of its exploiters.

In I90 I Beijernick's investigation led to the extremely important discovery of aerobic bacilli to which he gave the name Azotobacter. Since that time many species of non-symbiotic nitrogen-fixing organisms have been found and much learned concerning their life activities, until today we recognize that the power of fixing nitrogen is inherent in many bacteria, yeasts, 


\section{I42 BACTERIA AND SOIL FERTILITY}

and molds, if conditions are ideal. But the Azotobacter appear to be king of all non-symbiotic nitrogen gatherers.

Where Do Nitrogen Fixers Occur?-The nitrogen-fixing organisms are widely distributed, occurring in most soils. Lipman examined forty-six soils from various parts of the world and found the Azotobacter in about one-third of them.

Several hundred Utah soils have been examined and all were found to fix nitrogen-many of them without the addition of carbohydrates. Aerobic Azotobacter are present in nearly all Utah soils. Hutchinson found the Azotobacter in all the Indian soils examined. They occur in cultivated more frequently and in greater numbers than in virgin soils. This probably accounts for the much higher nitrogen-fixing power of cultivated soils.

Azotobacter were found in only two out of sixty-four localities in the soils of Danish forests. Both of the soils which gave positive tests were from beechwood forests and contained calcium carbonate. Although the soils of these forests rarely contain enough carbonate to effervesce, they are usually neutral or slightly alkaline. They contain calcium, but in forms other than the carbonate. It is generally understood that Azotobacter occur commonly in soils which contain sufficient calcium carbonate to effervesce when acid is added and that they scarcely ever occur in acid soils.

\begin{tabular}{l|c|c}
\hline \hline \multicolumn{1}{c|}{ Soil } & Depth (cm.) & Average Nitrogen Fixed (mgm.) \\
\hline Little Hoos & 10 & 9.23 \\
Little Hoos & 20 & 7.29 \\
Little Hoos & 30 & 4.60 \\
\hline
\end{tabular}

They are confined almost entirely to the first three feet of soil, although they have been found in soil at all depths down to the tenth foot in the very favorably constituted loess soils of Nebraska. They are most active in the upper few inches of soils, as is indicated by the above results obtained by Ashby.

Reports on some Hawaiian soils show them to be equally active 
at all depths to four feet, but this must be considered an exception for the examination of numerous soils in Utah has shown a gradual decrease in nitrogen-fixing powers with depth. The average of several hundred determinations in both solution and soil media are given below:

\begin{tabular}{l|c|c}
\hline $\begin{array}{c}\text { Depth of } \\
\text { Sample }\end{array}$ & $\begin{array}{c}\text { Nitrogen Fixed in Ioo gm. of } \\
\text { Soil with I.5 gm. Mannite }\end{array}$ & $\begin{array}{c}\text { Nitrogen Fixed in roo cc. of } \\
\text { Ashby's Solution with I.5 Mannite }\end{array}$ \\
\cline { 2 - 3 } & $m g m$. & $m g m$. \\
First Foot & 5.28 & 2.11 \\
Second Foot & 2.42 & 0.77 \\
Third Foot & 1.55 & 0.58 \\
\hline
\end{tabular}

These samples were collected with such great care that there was no possibility of the mixing of one foot-section with another. There is about one-half as much nitrogen fixed in the second as in the first foot and one-fourth as much in the third as in the first.

Condition for Growth.-The distribution and the physiological efficiency of the nitrogen-fixing organisms, especially of the Azotobacter species, are governed by the physical and chemical properties of the soil, foremost among which is its calcium or magnesium carbonate content. Some workers make use of this in obtaining pure cultures of Azotobacter, for it is found that by picking out the crystals of the carbonate from the soil and seeding them into nitrogen-free media the likelihood of obtaining the organism is greatly increased. The addition of calcium carbonate to a soil often increases its nitrogen-fixing power, the extent depending on the lime requirements of the soil and on the fineness of the added limestone.

Christensen has suggested that the Azotobacter be used as an index of the lime requirements of a soil. The test should include both a search for the organisms in the soil and a test of their ability to grow when innoculated into the soil. $\mathrm{He}$ and Larson examined more than a hundred soils of known lime requirement. 


\section{I44 BACTERIA AND SOIL FERTILITY}

They determined the carbon dioxid set free by acids, the amount of calcium dissolved by an ammonium chloride solution, the behavior of the soil toward litmus, and the biological test. The result of this test was that the biological test agreed with the known condition in 90 per cent of the cases, the ammonium chloride in 50 per cent, the litmus in 40 per cent, and the carbon dioxid failed more of ten than not to indicate the correct condition of the soil.

What Do They Feed Upon?-These organisms probably require for their nutrition the same elements as do the higher plants, namely, carbon, hydrogen, oxygen, nitrogen, potassium, sulfur, calcium, magnesium, and iron, and possibly aluminum and manganese.

They obtain their carbon and hydrogen from organic compounds, preferably from carbohydrates. Oxygen is obtained either from the atmosphere or from combined sources, depending on the species and the conditions under which they are grown. The other elements are obtained from the soil.

A marked difference between these and the higher plants is that they possess the power of obtaining their nitrogen from the air. In the presence of combined nitrogen, however, they become lazy and obtain their nitrogen in the easier way from the soil. Small quantities stimulate, whereas large quantities discourage nitrogen fixation since the organisms live on the nitrates. This may be due to a number of causes: (I) direct toxic action of the salt, (2) antagonism of other organisms which it favors, (3) the using up of the energy supply by these organisms, and (4) the discouragement of fixation by the use of sodium nitrate. They must also have water and a suitable temperature. These are the same as for the nitrifiers, hence need not be considered here.

From Whence Their Energy?-The nitrogen-fixing organisms differ widely from other plants in their energy requirements. This is due to the fact that they are causing the lazy nitrogen to combine with other elements. This requires energy in greater quantities than is required by other bacteria. This must be supplied by organic compounds, preferably one of the carbohydrates. 


\section{NON-SYMBIOTIC NITROGEN FIXATION 145}

These come from the plant and animal residues brought to the soil and differ in value with various substances, as may be seen from the following:

\begin{tabular}{l|c}
\hline \multicolumn{1}{c|}{ Material } & $\begin{array}{c}\text { Nitrogen Fixed in Ioo cc. of } \\
\text { Solution after 3 Weeks (mgm.) }\end{array}$ \\
\hline Fresh Straw & 10.0 \\
Fresh Stable Manure & 9.8 \\
Fresh Peat & 9.3 \\
Green Manure & 8.0 \\
Beijernick's Mannite Solution & 5.6 \\
\hline
\end{tabular}

After humification these substances are even more readily assimilated and the nitrogen fixation greater than when the unhumified substance is used.

Other workers have found that stable manure, even up to 3 per cent, greatly stimulated bacterial activities. It is certain that humus can act as a source of energy and usually stimulates bacteria, but the extent is governed largely by its composition and by the quantity of available combined nitrogen which is being supplied with it to the organism. In addition to this, corn roots, corn stalks, oak leaves, lupine, alfalfa, maple leaves, and pine needles may all serve as a useful source of energy to the nitrogen-fixing organisms. Apparently the tissues from the nonlegume give a greater gain than do those from the legumes.

The influence of stable manure upon the nitrogen-fixing powers of the soil under field conditions is seen from the following results obtained by the senior author. The nitrogen fixed in the unmanured soil is taken as Ioo per cent.

\begin{tabular}{c|c}
\hline \hline \multicolumn{1}{c|}{ Treatment } & Nitrogen Fixed (Per cent) \\
\hline No manure & I00 \\
5 Tons of Manure per Acre & 103 \\
10 Tons of Manure per Acre & 110 \\
15 Tons of Manure per Acre & 105 \\
20 Tons of Manure per Acre & I03 \\
25 Tons of Manure per Acre & IOI \\
\hline
\end{tabular}




\section{I46 BACTERIA AND SOIL FERTILITY}

Crop.-Heinze called attention to the fact that the fallowing of the soil increased its nitrogen-fixing power. This may be due to better aeration, moisture, temperature, etc., and not to any depressing influence exerted directly by the plant. Most experiments which consider plant and bacterial activity may be interpreted in this light. Hiltner maintains that the non-symbiotic nitrogen-fixing bacteria are stimulated in their activities by the growing plant roots. There may be considerable truth in this for here the higher plants are rapidly removing from the solution the soluble nitrogen compounds. In this case, the nitrogen-fixing organisms would be forced either to compete with the higher plants for the soil nitrogen or else make use of their ability to live upon the atmospheric nitrogen. It is certain that different cultural methods vary sufficiently with crops to influence profoundly a soil's nitrogen-assimilating properties, for the Azotobacter occur more widely distributed in cultivated than in virgin soil. The analyses of hundreds of samples of cultivated and virgin soils in Utah have in nearly every case shown the virgin soil to have a low nitrogen-fixing power as compared with the cultivated soil. This was the case even where the soil was incubated without carbohydrates and the nitrogen determined directly. The average results from many determinations were as follows:

\begin{tabular}{|c|c|}
\hline Soil & Nitrogen Fixed (mgm.) \\
\hline $\begin{array}{l}\text { Virgin Soil } \\
\text { Cultivated } \\
\text { Wheat } \\
\text { Alfalfa } \\
\text { Fallow }\end{array}$ & $\begin{array}{r}6.99 \\
\text { I } 4.28 \\
\text { II } .83 \\
\text { I } 2.24 \\
22.8 \mathrm{I}\end{array}$ \\
\hline
\end{tabular}

It would, however, be possible to fallow or crop soils so continuously that extremely small quantities of plant residue would be returned to the soil, under which conditions there may be a decrease in nitrogen fixation. The conditions of moisture and 
aeration are much more nearly ideal in a fallow soil than in a cropped soil. It is just possible that the high fixation noted where wheat is grown continuously may be due to the method in vogue in the arid districts of leaving the greater part of the straw on the soil. This would serve as readily assimilable carbonaceous material for the Azotobacter. Fallowing not only increases the assimilable nitrogen but also the available phosphorus of the soil, a liberal supply of which causes the Azotobacter to utilize its energy more economically.

How is the Nitrogen Fixed?-How different are the ways of man and the microbe! Man fixes nitrogen by means of a gigantic arclight in a chimney through which a current of hot air is blown. The flaming disc has a diameter of seven feet and reaches a temperature in the neighborhood of $6,300 \mathrm{~F}$. The gas which he obtains when dissolved in water yields nitric acid. Or, in another method air is cooled to - $194 \mathrm{C}$., the nitrogen boiled off, mixed with hydrogen in the proportion of $\mathrm{I}$ to 3 , heated to a temperature of $\mathrm{I}, 300 \mathrm{C}$., and then passed over finely divided uranium. There results ammonia. This mixed with oxygen and passed through platinum gauze, yields nitric acid. Thus in all synthetic processes there is used great variations in temperature and huge, complicated, expensive apparatus.

When the microbe fixes nitrogen there is also a real conflagration in which plant residues act as the fuel and the bacterial body the furnace. But how different are the two! The microbe is 90 per cent water. It works in the dark, damp, warm soil and generates little heat and no light. We know its end products are not the simple nitric acid, ammonia, or cyanamid but complex proteins. These we know are similar to those found in plants. They are formed from the same blocks. Some are soluble; others insoluble. All are broken down by bacteria and yield food for the higher plants. We do not know the first products which are produced in their formation nor the marvelous way in which the lazy nitrogen is enticed to join hands with carbon, hydrogen and oxygen. We can only surmise that the future will unravel the mystery. But when unravelled, as it surely will be, the 
wonderful advancements of the past decade will seem as little beside it.

Properties of Azotobacter.-In size and shape the Azotobacter are more like the yeasts than bacteria. They are eggshaped with a marked tendency to form agglomerations and of ten occur as involution forms. 'They are accompanied by small rod-

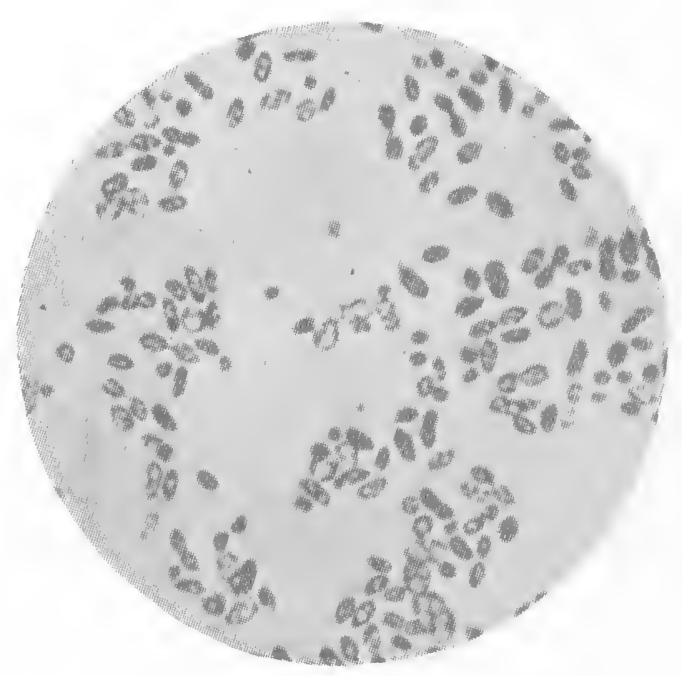

FIG. 3I.-Azotobacter cells. (After Löhnis.) shaped organisms with which they probably live in a form of symbiosis, the full significance of which is not well understood. It may be that they help the $A$ zotobacter digest the more resistant plant tissue and use up much of the fixed nitrogen, and hence the Azotobacter are stimulated to greater activity.

When grown in the laboratory they produce very interesting pigments. 'These vary in color from brown to black of $A$. chroococcum to a yellow or orange of the $A$. vinelandii. The power to produce this pigment at times is lost, but they continue just the same to fix nitrogen. Probably the pigment is just a curious by-product which has no importance. The intensity of the pigment varies with the medium on which the organism is grown. It is intensified by the presence of nitrates.

Soil Inoculation.-High hope was entertained that the nitrogen problem in agriculture had been solved when Caron announced that he had prepared a culture of bacteria which would enable non-leguminous plants to utilize free atmospheric nitrogen, provided certain precautions were observed. Many of the results which he reported on pot experiments were clearly in favor of the inoculated soil. Stoklasa was one of the first to study in detail the commercial preparation "alinit" which was placed on the market as a result of Caron's work. His findings were fully as favorable as Caron's, but the work of others soon demonstrated 


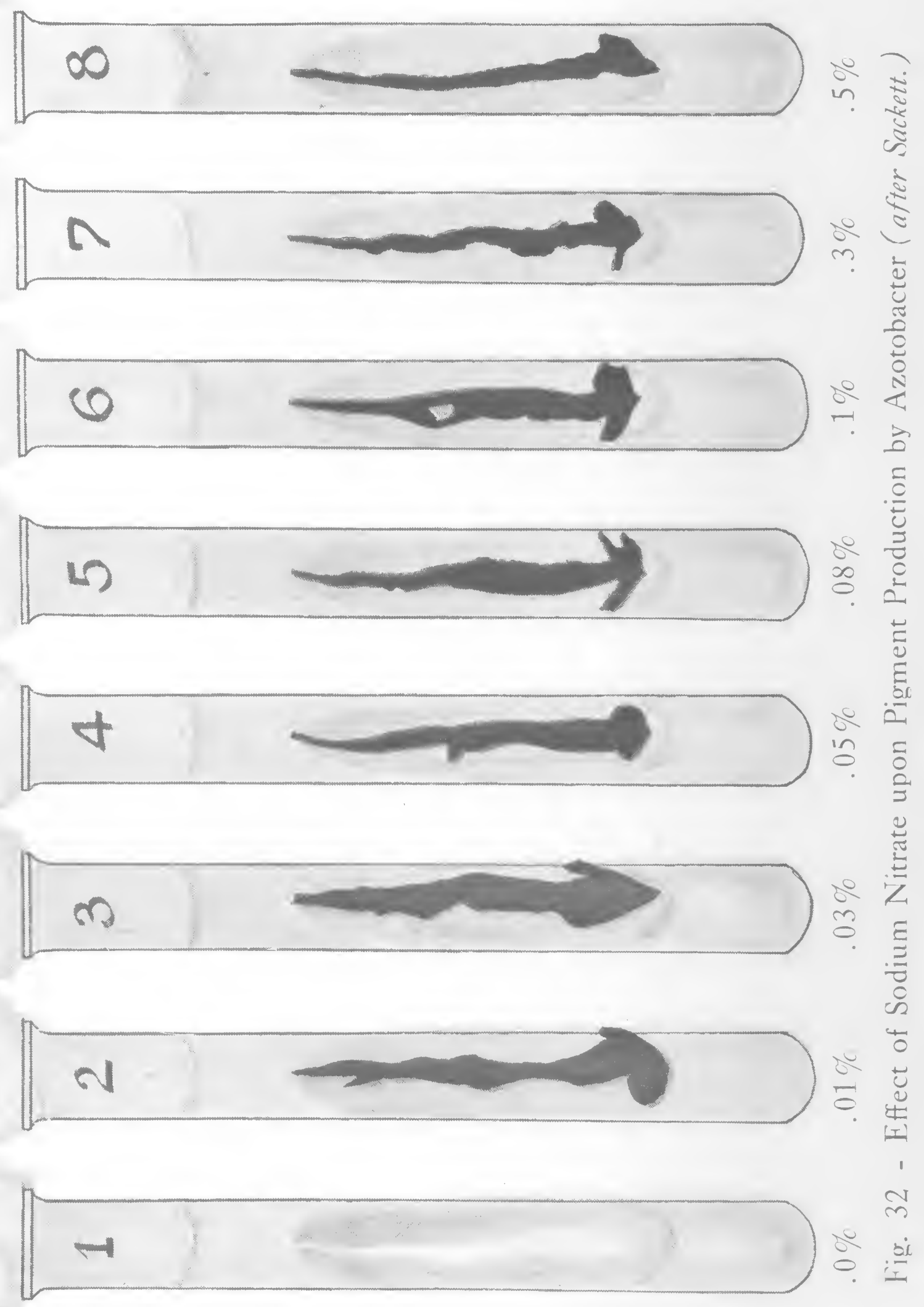


that alinit neither in the laboratory nor in the field had the ability to fix nitrogen. When Beijernick discovered the free-living aerobic nitrogen fixers, the hope that soil inoculation might be so perfected that it would be beneficial to crops was revived, and since that time many investigators have attempted to inoculate soil in order to increase its crop-producing powers but usually with negative results. Some have made great clarms for soil inoculation. They have found that soils, inoculated with Azotobacter chroococcum and adequately supplied with carbohydrates and lime, show an increase in the number of nitrogen-fixing organisms and also an increase in yield.

There may be a decrease in the crop during the first year when carboyhdrates and Azotobacter are added to the soil with a marked increase in crop during the second and third years. Even then the soil may be left richer in nitrogen than it was at first.

Effect of Dextrose and Sucrose on the Productiveness and Nitrogen Content of the Soll

\begin{tabular}{|c|c|c|c|c|c|c|c|}
\hline \multirow{3}{*}{$\begin{array}{c}\text { Carbohydrate } \\
\text { Added per } \\
\text { Ioo gm. of } \\
\text { Soil }\end{array}$} & \multicolumn{4}{|c|}{ Crops Obtained } & \multirow{3}{*}{$\begin{array}{c}\text { Total } \\
\text { Nitrogen } \\
\text { Removed } \\
\text { in } \\
\text { Crop }\end{array}$} & \multirow{3}{*}{\begin{tabular}{|c|} 
Total \\
Nitrogen \\
Left in \\
Soil \\
Spring \\
Igo6
\end{tabular}} & \multirow{3}{*}{$\begin{array}{l}\text { Nitrogen } \\
\text { as } \\
\text { Nitrates } \\
\text { (p.p.m.) }\end{array}$} \\
\hline & \multicolumn{2}{|c|}{ Oats, 1905} & \multicolumn{2}{|c|}{ Sugar-beets, 1906} & & & \\
\hline & $\begin{array}{c}\text { Dry } \\
\text { Matter }\end{array}$ & $\begin{array}{l}\text { Yield of } \\
\text { Nitrogen }\end{array}$ & $\begin{array}{c}\text { Dry } \\
\text { Matter }\end{array}$ & $\begin{array}{l}\text { Yield of } \\
\text { Nitrogen }\end{array}$ & & & \\
\hline $\begin{array}{l}\text { None } \\
2 \% \text { Dextrose } \\
2 \% \text { Sucrose } \\
2 \% \text { Sucrose }\end{array}$ & $\begin{array}{r}100.0 \\
32.3 \\
33 \cdot 3 \\
37 \cdot 7\end{array}$ & $\begin{array}{r}100.0 \\
62.5 \\
58.7 \\
78.1\end{array}$ & $\begin{array}{l}100.0 \\
186.0 \\
179.0 \\
283.0\end{array}$ & $\begin{array}{l}100.0 \\
190.0 \\
195.0 \\
339.0\end{array}$ & $\begin{array}{c}g m . \\
0.591_{4} \\
0.681_{4} \\
0.6800 \\
1.0092\end{array}$ & \begin{tabular}{|l} 
percent \\
0.093 \\
0.105 \\
0.105 \\
0.119
\end{tabular} & $\begin{array}{l}10 \\
17 \\
15 \\
37\end{array}$ \\
\hline
\end{tabular}

It is often the case that the addition of starch to a soll during the first year retards plant growth. This injurious action may be due to the increased bacterial activity in the soil brought about by the carbohydrates which injure the roots of the plant by withdrawing oxygen and by forming hydrogen sulfide in the deoxygenated atmosphere of the soil through the reduction of sulfates by the bacteria. Or what is more likely the increased number of 
bacteria may compete with the higher plant for the limited supply of available nitrogen of the soil. This latter appears to be the correct explanation as legumes which are not dependent upon soil nitrogen if properly inoculated are not retarded by carbohydrates.

The effect produced by the application of carbohydrate also varies with the season. If applied to the soil in the spring when the soil temperature is low and when other bacteria are more active than Azotobacter, the results are that they rapidly multiply and compete with the higher plants for the limited available plant food. If, however, the carbohydrates are applied in the autumn directly after the removal of the crop when the soil is warm, Azotobacter are active with the result that sufficient nitrogen is fixed to produce an increased crop the following season.

Many workers have noted either no effect or even a detrimental effect when soils are treated with the carbohydrates and then inoculated with Azotobacter. This may be due in a great measure to any or all of the following factors: (I) absence of a suitable environment, such as temperature, moisture, aeration, food, and alkalinity; (2) absence of a suitable host from which Azotobacter may obtain part of its carbon; and (3) injurious effects due to the decomposition products of the carbohydrate added.

There is considerable interest in the work of Bottomley who uses bacterized peat or humogen. The bacterizing process consists of three stages: ( $\mathrm{I}$ ) treatment of peat with a culture solution of the special "humating" bacteria and an incubation of it at constant temperature for a week or ten days during which period soluble humates are formed; (2) destruction of the humating bacteria by sterilization with live steam; and (3) treatment of this sterilized peat with mixed cultures of nitrogen-fixing organisms- $A$. chroococcum and $B$. radicicola-and an incubation at $20^{\circ} \mathrm{C}$. for a few days, after which it is ready for use.

Theoretically, there is much in this process which recommends it, for there is no abrupt change in environmental conditions for the organism added, as would be the case when added from laboratory cultures. Moreover, they are added in enormous quanti- 
ties and with a source of carbon which is not far different from that found in the soil. Russell, however, after carefully reviewing all of the experimental evidence on the subject, concludes: "There is no evidence that 'humogen' possesses any special agricultural value. There is not the least indication that it is fifty times as effective as farmyard manure, to quote an oft-repeated statement, and there is nothing to show that it is any better than any other organic manure with the same nitrogen content." Furthermore, he concludes that there is no definite evidence that "bacterization" really adds to the value of peat.

The conclusion is evident that soil inoculation in order to be successful must be accompanied by the rendering of the physical and chemical properties of the soil ideal for the growth of the specific organisms to be added. A few organisms placed in a new environment already containing millions can never hope to gain the ascendancy over the organisms naturally occurring in the soil, for they have been struggling for countless generations to adapt themselves to the environment, and only those which are fitted have survived. The problem becomes even more complicated when we recall the findings of Lipman that the bacterial flora of a soil is in many cases entirely changed by climatic conditions. On this account it would appear that to ever make soil inoculation a success the chemical, physical, and even the biological condition must be made suitable for the growth of the specific organism added. Furthermore, strains of the organism must be used which have been evolved under similar climatic conditions.

Soil Gains in Nitrogen.-It is well established that many forms of microörganisms possess the power of fixing nitrogen either when grown alone or in combination with other microörganisms of the soil. Many of these have been obtained in pure culture and their morphology and physiology carefully studied. The most favorable conditions for their maximum nitrogen fixation in pure cultures in liquid solutions have been accurately determined. Some of the conditions requisite for their activity in soils are known, but on this phase of the subject there are many 
gaps in our knowledge and much work must yet be done before we can state definitely the part which they play in the economy of nature and before we can say which are the very best methods for increasing their usefulness. Nevertheless, it is interesting to consider the results obtained by a few workers.

Berthelot's early laboratory experiments led him to believe that sands and clays may fix in a year from seventy-five to 100 pounds of nitrogen to the acre. In two exceptional instances he noted that nitrogen was fixed by sands at the rate of 525 pounds and 980 pounds an acre, but soils which contained fairly large quantities of nitrogen never made marked rapid gains.

Thiele, on the other hand, maintained that while there is no doubt that $A$ zotobacter possessed the power of fixing free nitrogen under laboratory conditions, yet it is not certain that conditions would be such in soils for any gain of nitrogen due to the activity of these organisms. We have already seen, however, that the $A$ zotobacter do not require as high a temperature for nitrogen fixation in soil as Thiele thought necessary. It is also certain that in most arable soils the temperature is sufficient during a large part of the year for a fairly rapid nitrogen fixation by bacteria.

Krainskii thinks that even better results should be obtained in soils than in pure solutions, for there the nitrogen fixers grow in symbiosis with auto-trophic organisms which produce organic compounds available to the $A$ zotobacter. In soils the nitrogen fixed is rapidly removed by other plants, because of which the slowing-up process which becomes perceptible so early in laboratory experiments should not occur.

In addition to an optimum temperature and moisture content of the soil, the $A$ zotobacter are dependent upon a supply of carbon for energy and inorganic nutrients for the building of cell protoplasm. Unfortunately, it is too often the case that under natural conditions those soils which are deficient in nitrogen are also lacking in available carbon, and especially in phosphorus, which are so essential for rapid nitrogen fixation. Then there are the technical difficulties which the chemist encounters in determining the gain or loss of nitrogen which occurs in soils under nat- 


\section{NON-SYMBIOTIC NITROGEN FIXATION I53}

ural conditions and which may be attributed to non-symbiotic nitrogen fixation.

There are, however, several cases in which this has been measured with a fair degree of accuracy. Lipman, in pot experiments carried on with a soil containing about 5,000 pounds of nitrogen per acre-foot of soil, found a gain of more than one-third this amount in two short seasons. Much of this must be attributed to non-symbiotic nitrogen fixation. To these soils had been applied solid and liquid manure which furnished to the organisms readily available supplies of energy and various necessary inorganic constituents. This fixation was not nearly so rapid where legumes were turned under as green manures. Koch found a gain of o.0I9 per cent in soil nitrogen during two seasons which must be attributed to non-symbiotic nitrogen fixation. In addition to this there was a threefold gain in the nitrogen content of the crops-oats, buckwheat and sugar beets-which must also be attributed to the action of Azotobacter. Hall noted an annual gain of 100 pounds of nitrogen on Broadbalk field at Rothamsted and twenty-five pounds on Grescroft field. He feels that much of this gain must be due to the action of non-symbiotic bacteria. Lipman points out that the actual gains of nitrogen are even greater, for this does not take into consideration the various losses which occur even under the best of conditions.

The analysis of a great number of soils in Utah showed that the average nitrogen content of the soil which had grown wheat and other non-leguminous plants for from twenty to fifty years was 0.2009 per cent, whereas adjoining virgin soil on the average showed only 0.1984 per cent of total nitrogen. The evidence is very strong that considerable nitrogen has been added to these soils by microscopic organisms, as is shown by the following:

I. In nearly every case the cultivated soil fixed much more nitrogen in the laboratory than did the virgin soil. This was the case when the soil was incubated with or without the addition of carbonaceous material.

2. There is a richer nitrogen-fixing bacterial flora in the cultivated than in the virgin soil. 


\section{I54 BACTERIA AND SOIL FERTILITY}

3. The conditions of moisture, alkalinity, and food constituents in the soil were-ideal for rapid nitrogen fixation, and the temperature of the soil was high enough during a considerable part of the year for the growth of Azotobacter.

4. The cultivation of the soil would increase aëration and available phosphorus in the soil.

5. The large quantity of plant residues would act as a supply of carbon which is readily rendered available by the soil's rich flora of cellulose ferments. If these soils had produced a wheat crop every alternate year and all of the nitrogen which had been added to the soil without loss from leaching or bacterial activity taken by the crop, it would have necessitated the addition of twenty-five pounds an acre yearly, which is evidently the very minimum which can be attributed in these soils to non-symbiotic nitrogen fixation.

Eighty different samples of these soils were incubated in the laboratory for twenty-one days and the gains in nitrogen determined by comparing with sterile checks. The soils were incubated without the addition of anything except sterile distilled water. At the end of the period the average gain per acre for the cultivated soils was 202 pounds and that for the virgin soil was ninety-two.

True, fixation would not continue long at this rate, for when the nitrogen content of the soil passed a certain limit decay bacteria would increase rapidly, and in the struggle for existence they are able with the advantages at their disposal to suppress the more slowly growing Azotobacter which would gain the ascendency again only when the nitrogen of the soil became low.

Thus, there is an upper as well as a lower limit to the nitrogen content of the soil as far as bacterial activity is concerned, but by making the conditions for nitrogen fixation as nearly ideal as possible we may maintain in a soil the upper and not the lower nitrogen content.

In conclusion, it may be stated that altho the part played by Azotobacter in maintaining the nitrogen of the soil has not been definitely measured, it is nevertheless an important factor. Hall 
NON-SYMBIOTIC NITROGEN FIXATION I55

found it to be at least twenty-five pounds, Löhnis thirty-seven and seven-tenths pounds, and the senior author twenty-five pounds per acre annually. It is, therefore, conservative to state, as has Lipman, that these organisms under favorable conditions add from fifteen to forty pounds of available nitrogen to each acre of soil yearly. 


\section{CHAPTER XV \\ SYMBIOTIC NITROGEN FIXATION}

The atmosphere over every acre contains about one-half ton of carbon and 25,000 tons of nitrogen. Plants never lack carbon, but they often starve in the midst of this vast ocean of nitrogen. All plants can obtain carbon from the atmosphere. Are there none which can obtain nitrogen from the air? If there are, which are they and under what conditions can they obtain it? These questions have been asked by many, and the unfolding of the answer constitutes one of the most interesting and practical phases of agricultural development.

Belief of the Seventeenth Century.-Today one cannot refrain from smling at the conclusion reached by van Helmont in the seventeenth century. He planted a willow weighing five pounds in two hundred pounds of soil. This he watered regularly for five years. At the end of this time he removed the soil from the roots and found its weight unchanged, whereas the willow had gained 164 pounds. From this he concluded that the willow had been produced from the water. He had overlooked the small quantity of carbon dioxid which a century and a half later Priestley concluded came from animal life and was removed by plant life. And what was more natural than for Priestley to also conclude that plants get their nitrogen from the air? His conclusions rested on crude qualitative tests; hence, it was not until the last quarter of the eighteenth century that it was fully established that plants obtain their carbon from the atmosphere.

Later Work.-Liebig considered all crops capable of securing nitrogen from the air, but the legumes and other broad-leaved plants were especially fitted for this task, as is witnessed by the fact that they benefit the succeeding cereal crop and do not respond as readily to nitrogenous fertilizers. 
About I 834 that adventurous South American traveler, Boussingault began a series of field experiments on his farm in Alsace. In these he studied no fewer than five rotations keeping accurate record of the loss and gain of the various elements. Interesting enough, he found that when the rotations contained legumes there were gains in nitrogen.

Experiments conducted in closed vessels on heated soil, however, soon demonstrated that the free nitrogen of the air was not available to the higher plants. Could it be that they were feeding on the ammonia of the air? No, experiments showed that this was not sufficient. Hence, for a number of years it was accepted as decisive that plants obtain their nitrogen from the soil.

This was contrary to the agricultural experience of all ages and the carefully conducted experiments of Rothamsted continued to point to the conclusion that legumes behave abnormally. Could it be that the deep-rooting legumes were bringing nitrogen to the surface? Later work explained the apparent contradiction in showing that Boussingault had used sterilized soil, whereas plants normally grow in unsterilized soil.

To Hellriegel and Wilfarth (1888) is due the credit of solving the mystery. They found that legumes grew quite normally in soils that lacked nitrogen, provided these soils were not previously sterilized. Growth was checked, however, in sterilized nitrogen-free soil because of lack of nitrogen. Addition to the soil of a small quantity of an infusion from unsterilized soil produced normal growth of the plants and resulted in a crop rich in nitrogen. If the added infusion was previously boiled, then its addition produced no effect at all; the plants were retarded in their development and the harvest showed no increase in nitrogen. The soil used in preparing the infusion must be taken from a field upon which the kind of plants used in the experiment had been cultivated. For example, if peas are taken the soil used for the watery extract must come from a field where peas have been previously grown.

The legumes grown in unsterilized soil and those watered with infusions of soil have upon their roots small knobs or tubercles. 
Wigand (I887) found that the tubercles contained true bacteria, and the following year these were obtained in pure cultures by Beijernick. He found further that there were bacteria associated with all tubercles, and altho the bacteria differed somewhat in the tubercles of different species of plants, still there were certain constant characteristics to be seen in them all. He, therefore, regarded the tubercles as the result of the action of bacteria and gave to the organism producing the tubercles the name of Bacillus radicicola. He regarded the so-called bacteroids of Woronin as degenerate involution forms of the bacteria, which appeared only after the bacteria have lost their vigor. In a later investigation, after isolating the bacteria and keeping them in pure cultures for many months, he was able to produce the tubercles at will by inoculating soils in which his plants were growing with the pure cultures of the organisms.

Later researches have confirmed all of Hellriegel's results and show conclusively that if sufficient precautions are taken to sterilize the soil in which leguminous plants are grown no tubercles result. It has been further shown that the tubercles grow on plants developing both in the light and in the dark but are larger on plants growing in the light; that they only appear on healthy plants; that they are very few on plants growing in well-washed sand; that if plants growing in sterilized soil be watered with brook or river water, tubercles occasionally develop but never in abundance; and that the infection of the roots occurs early in the growth of the plant and cannot take place in the older roots.

The plant gets its nitrogen from the bacteria growing in the tubercles and the bacteria get their carbohydrates from the plant. What a beautiful example of the division of labor! Here we have two friends living together, each performing the task which it has become best suited to do through ages of specialization. The legume with its broad, specially constructed leaves drinks in carbon dioxid and mysteriously gathers up the heat and light waves. These enter the cell, the laboratory of that master chemist, chlorophyll, where they are transformed into carbohydrates. 
This fuel is silently passed down to those tiny dynamos, the bacteria, which fill the nodules on all the roots. Here the carbohydrates are burned, and the resulting energy used to cause the lazy nitrogen to. join hands with hydrogen and oxygen. S o m e of the resulting protein is used in the construction of more bacterial cells, but most of it is passed on to the plant and then becomes a part of its tissues and later its seeds. The bacteria probably receive this fuel in the form of a soluble carbohydrate, but we do not understand the medium of exchange used in payment. Is it a nitrite, a nitrate, an amino-acid, or a protein? We only know it is a nitrogen-carrying compound which can be utilized by the plant in all of its constructive

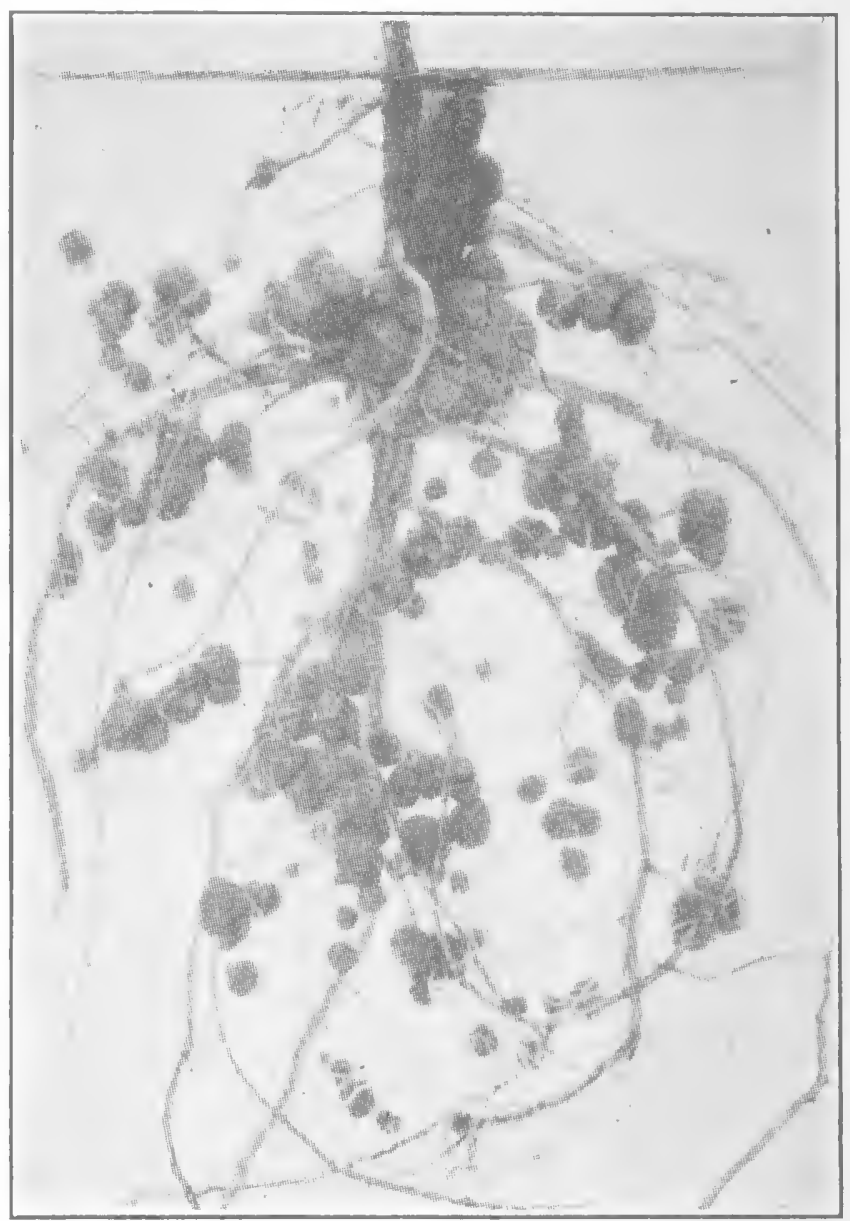

FIG. 33.-Nodules on soy beans. (After Russell and Hasting.)

\section{metabolism.}

The Nodules.-These small wart-like protuberances which occur only on the roots of infected legumes are the home of bacteria-like microörganisms called bacteroids. These get into the roots of the young, partly starved plants. As the tip of the root hairs of the legumes pushes itself out into the soil, it chances to come into intimate contact with the microbe. Some scientists believe that the organism is attracted to the plant by chemotaxis. They believe that the plant excretes a substance, probably a carbohydrate, which passes into the soil solution and attracts the mo- 
tile organism. It has been shown that the organism travels in the soil at a comparatively rapid rate. Nevertheless, the number of root hairs infected is too small to lend support to a chemotactic theory. However this may be, the organisms cluster at the tip of the root hair and by some means dissolve the cell wall. This enables the microbe to enter the root hair. As a result there is a decided bending of the tip causing it to resemble a shepherd's crook. This is taken as a sign of complete infection. Other hairs which form after this infection appear to be resistant to the attack of other legume bacteria. The bacteria once inside the cell rapidly multiply, and the irritation thus produced causes enlargement of the plant at this point.

The size, distribution, and appearance of the resulting nodules vary with a number of factors. They are large and more numerous where aëration is best in the soil. In tight or water saturated soils they occur at the surface and are of ten found colored green similar to sunburned potatoes. At the period when seeds are forming on the plant most of the nodules are soft and the internal tissue sloughs off, leaving the more resistant outer tissue a mere shell which later decays.

The organisms do not seem to enter the root hairs of old plants or even well-nourished plants. It would, therefore, seem that the plant has to weaken thru the lack of food or for other causes before the organism can become established on the roots.

Conditions Favoring Growth.-The legume bacteria are all aerobic and the nodules on the roots of the plants are usually near the surface. Altho nodules will form on plants grown in water cultures, yet they are not as large and active as when grown in a well-aërated soil. The addition of oil to a soil or water culture in which legumes are growing prevents the formation of the nodules. Moreover, as shown by Whiting, the legumes get their nitrogen thru the root and not the leaves. The result of cultivation of legumes is, therefore, threefold: (I) the loosening up of the soil makes available to the nodule bacteria atmospheric nitrogen and oxygen; (2) the working of the soil increases other bacterial activity which in turn renders soluble potassium, 
phosphorus, and other essential elements in the soil; and (3) the loose aërated surface tends to conserve the moisture of the lower layers which can be drawn on by the plant, thus making more nearly optimum moisture conditions.

Moisture.-The root systems of plants vary greatly with the moisture content of the soil. Gain found that legumes grown in moist soil spread widely and were full of water, became covered with root hairs, and presented a large surface of young tissues. In the dry soil the roots were less spreading and the epidermis was greatly thickened.

In moist soil the tubercles of the peas were scattered all over the roots, were five or six times as abundant as in the dry soil and were about four times as large and ovoid in shape. In the dry soil, however, no tubercles were produced on the superficial roots. At a depth of about 20 centimeters some tubercles were found of a hemispherical shape and much smaller than those grown in moist soil.

On beans about twenty times as many tubercles were found in the moist soil, and microscopic examinations showed important differences in the number of bacteria present and the structure of the tubercles. Similar results were obtained with lupines and other plants. This is what is to be expected, for when the root system is not actively functioning the nodules are slowly destroyed by the nodule-forming bacteria within and the saprophytic bacteria without. The nitrogen fixed by the plant is proportional to the number and size of the nodules. Hence, the gains made in combined nitrogen are dependent upon the water applied to the legume. This optimum will vary with different soils. Kalantarov found in a loam soil that nodule bacteria require for their growth a minimum moisture content of about 30 per cent, whereas Prucha found in a sandy soil the optimum moisture content was from 20 to 40 per cent. Wilson found that an increase in moisture content from 35 to 45 per cent more than doubled the production of nodules, while with an increase of from 45 to 55 per cent it was nearly doubled. Therefore, water is necessary for the normal functioning of the plant and bacteria, and it tends 
to leach out the soluble nitrogen and thus stimulates to greater action the legume bacteria, for it is known that the legume feeds first on the combined nitrogen of the soil and turns to the atmosphere only when this is greatly reduced.

Excessive quantities of water may exclude the nitrogen from the roots and also favor anaerobic action, both of which would be detrimental to the legume bacteria.

Influence of Fertilizers. - The legume bacteria require the same elements for their growth as do other plants, and the application of fertilizers to a soil which increases the available potassium and phosphorus is attended by an increased bacterial activity. However, it has long been known that nitrates inhibit nodule formation. Wilson found that nodule development was prevented by the presence of nitrates, sulfates, and ammonium salts, although the organisms retain their vitality in the presence of these salts. It is thought by some that the addition of soluble nitrates to the soil decreases by a kind of compensatory action the formation of root tubercles by legumes. Legumes growing on soil rich in nitrates may actually be immune to the nodule bacteria and prevent their entrance into the roots. Small quantities of nitrates tend to stimulate.

Legumes Associated with Non-legumes.-For centuries it has been the practice in China, Japan, Western Asia, Northern Africa, as well as in ancient Rome, to grow legumes and nonlegumes in combination, and there is no doubt but that time and again practical farmers have noted the more vigorous growth and darker green of non-legumes when so grown long before the investigations of Hellriegel and his associates established the fact that legumes are capable of utilizing uncombined atmospheric nitrogen, His discovery gave the key to the mystery-the nonlegume was getting combined nitrogen from the legume. This was strikingly demonstrated by a very ingenious experiment conducted by Lipman. He grew non-leguminous plants in soil in a porous pot surrounded by earth in a larger glazed earthenware pot in which leguminous plants were growing and found that under favorable conditions non-legumes associated with legumes may 
secure large amounts of nitrogen from the latter. This power of supplying nitrogen to non-legumes varies with different legumes. At times it may appear as an increased yield, whereas at others it may appear as an increased proportion of nitrogen in the dry matter of the non-legume or both. The following table gives the percentages of increase in the protein content and length of leaf in the grasses grown with clover over grasses grown alone (Evans):

\begin{tabular}{l|c|c}
\hline \multicolumn{1}{c|}{ Kind of Grass } & $\begin{array}{c}\text { Prote1n } \\
n \times 6.25\end{array}$ & Length of Leaf \\
\hline Timothy grown in lawn plat & $\begin{array}{r}18.89 \\
7.68\end{array}$ & $\begin{array}{l}21.27 \\
19.4 \mathrm{I}\end{array}$ \\
\hline
\end{tabular}

This, however, varies with the soil, and there may be conditions in which not only the protein content of the non-legume is slightly reduced by the association with the legume but that the percentage of nitrogen in the legume may decrease as the proportion of non-legume in the mixture increases. Even in these cases the total nitrogen of the combined crops is usually increased, provided the legumes are properly inoculated.

Soil Gains in Nitrogen.-The gains made by soil in nitrogen are dependent upon a number of factors.

(I) It is self-evident that the soil must be in good physical condition for maximum nitrogen gains. (2) The soil must contain the elements essential to plant growth, with the exception of nitrogen. The law of minimum holds rigidly in this case and the gains in nitrogen are determined by the limiting element of plant production other than nitrogen. (3) Soils which contain sufficient available nitrogen for the production of good crops gain little, if any, nitrogen from the growth of legumes, for the plant together with the bacteria feed first upon the combined nitrogen of the soil and only upon atmospheric nitrogen when the soil nitrogen is exhausted. Soils may contain an abundance of combined organic nitrogen which for some reason is not rendered 
available and still gain from the turning under of properly inoculated legumes. (4) The legume must be properly inoculated; otherwise, it obtains its nitrogen as do other plants. (5) The soil must be a suitable home for the legume and bacteria, that is, it must have a correct reaction, moisture, temperature, and aëration

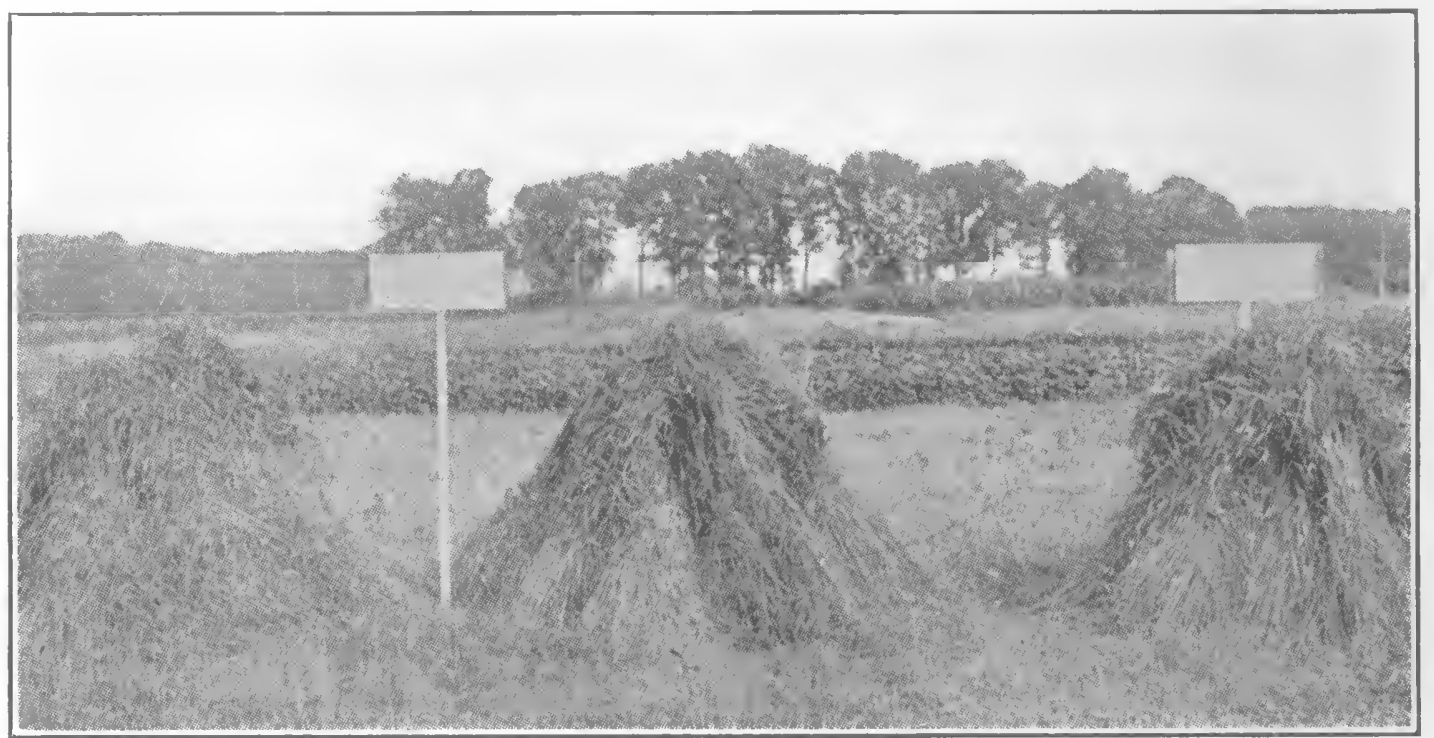

Fig. 34.- Influence of legumes on crop yield. The two shocks of wheat on the left were grown on $1 / 20$ acre after a legume as green manure, the one on the right was grown on $\mathrm{I} / 20$ acre without a legume as green manure. (After Lipman and Blair.)

for maximum nitrogen fixation. Hence, we can expect to find a wide divergence in the results reported by investigators.

Frank, in I 89 I, found that soil which had been green-manured with legumes showed an appreciable gain of nitrogen. And it is a well-known fact that in sand culture experiments wherein the nitrogen of the soil is very low that much more nitrogen may be removed in the legume crop than was found at first in the soil, and after the removal of the crop the soil may have gained in nitrogen. But what would happen in normally productive soil? The most reliable data now existing are contributed by the Illinois Experiment Station and indicates that two-thirds of the nitrogen in legumes grown on soils of normal productive power is obtained from the air. These figures were obtained from the analysis of 
inoculated and non-inoculated legumes from like areas of normal soils and as a result of pot experiments. Computed on these data a four-ton alfalfa crop adds 132 pounds, a four-ton crop of clover adds 107 pounds, a four-ton crop of cowpea hay adds I I 5 pounds. This nitrogen is added to the soil, provided the total crop is plowed under.

These are the quantities of nitrogen which reach the soil under ideal conditions, but some may be lost under natural conditions with the drainage and possibly by other means. The New Jersey Experiment Station has reported a gain of 200 pounds per acre where crimson clover had been grown and plowed under, whereas the Rhode Island Experiment Station, as a result of pot culture experiments, reports a gain of 400 pounds per acre yearly. This experiment extended over five years, and legumes were grown both in the summer and in the winter. The tops of the summer legumes (cowpeas and soybeans) were removed from the soil, while the winter legumes (vetch) were turned back into the soil.

Shutt, in pot and plat experiments extending over two years in which mammoth red clover was grown on soil and turned under, showed a gain of 179 pounds of nitrogen per acre to a depth of 9 inches in the pot experiments and $\mathrm{r} 75$ pounds to a depth of 4 inches in the plat experiments. A light sandy loam with a sandy sub-soil, when planted to clover continuously and reseeded every two years, doubled in nitrogen in ten years. This was a yearly gain of nitrogen of fifty pounds per acre.

Shall we Inoculate?-The early experiments demonstrated that legumes assimilate atmospheric nitrogen only when properly inoculated. Since that time much has been written on soil inoculation. However, it is being found that in the majority of cases where the physical and chemical conditions of the soil are optimum, the ordinary legume bacteria are already present. This is especially true where that particular legume has been grown in that district for some time. The legume organism may have been in the virgin soil having come from the native legume, or carried into the soil with manure or dust.

When legumes are being grown on a piece of land for the first 
time it may be necessary to supply the requisite legume bacteria. The bacteria to apply will vary with the specific legumes, as different legumes require different bacteria. Experience has taught that the following may

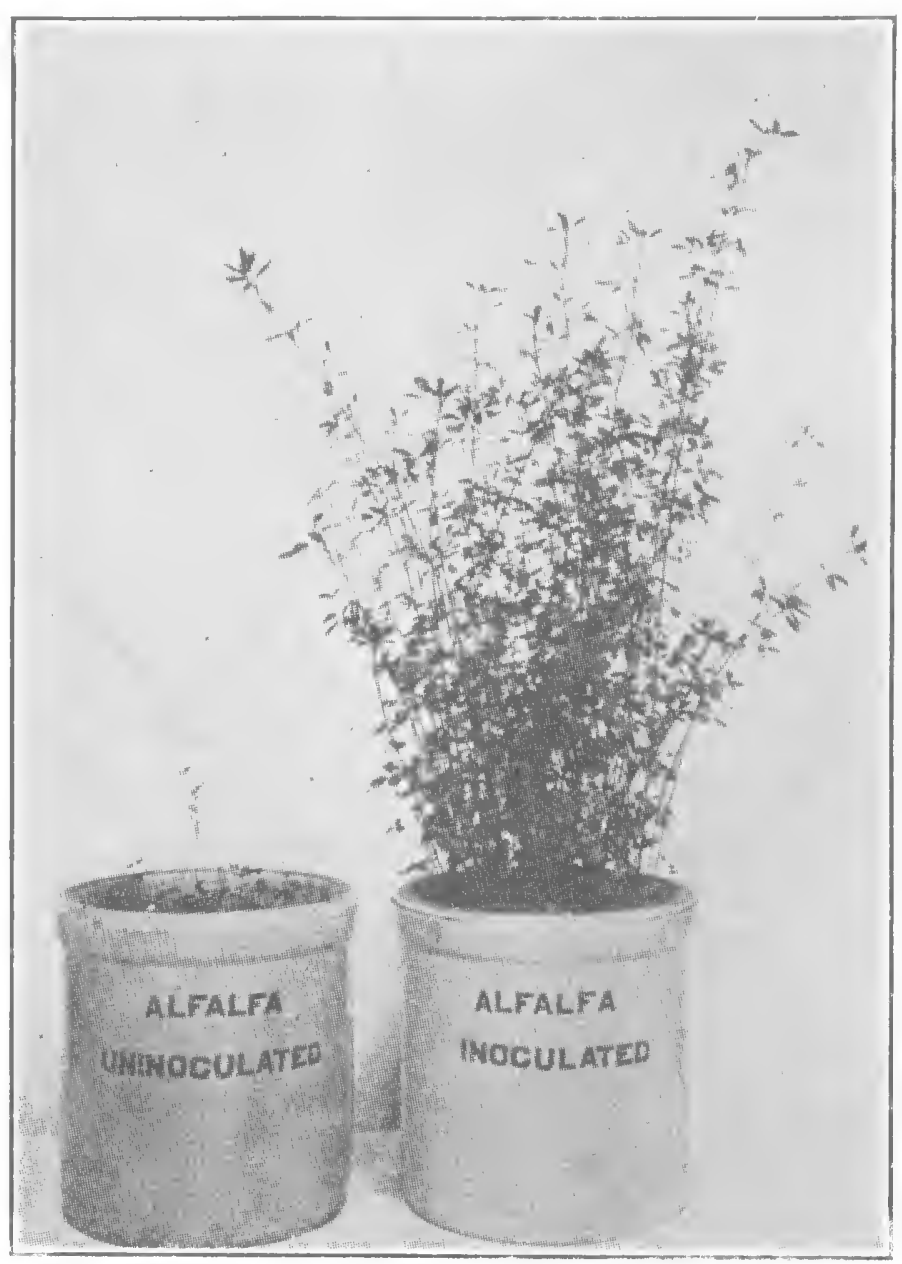

FIG. 35.-Effect of inoculation on alfalfa. The soil contained no nitrogen. By the aid of the nodule forming bacteria the inoculated plants have been able to secure nitrogen from the air. (After Russell and Hasting.) be used in inoculating various legumes:

(I) $\mathrm{To}$ inoculate red clover, use the bacteria from red clover, mammoth red, alsike, crimson, Egyptian, or white clover.

(2) To inoculate alfalfa, use the bacteria from alfalfa, sweet clover, bur clover, yellow trefoil, or fenugreek.

(3) $\mathrm{To}$ inoculate garden peas, use the bacteria from the garden pea, hairy vetch, spring vetch, wild vetch, broad bean, lentil, sweetpea, or perennial pea.

(4) $\mathrm{To}$ inoculate cowpeas, use the bacteria from the cowpeas, partridge pea, peanut, Japanese clover, velvet bean, lima bean, wild indigo, or tick trefoil.

(5) To inoculate garden beans, use the bacteria from garden, navy, kidney, or scarlet-runner bean.

(6) To inoculate lupine, use the bacteria from lupine, serradella, or wild lupine.

(7) To inoculate soybeans, use the bacteria from the soy bean. 
The case of soil inoculations is quite similar to a condition which too of ten exists in the industrial world. The farmer crops his soil year after year giving little or no attention to its physical or chemical properties. Conditions within it become unfit for microbial growth. The beneficial bacteria "go on a strike." This is brought to the attention of the farmer by decreased yields and, if he be an experienced hand, by the appearance of his crops. But in place of using his knowledge and time to make conditions in the soil fit for the life of his tiny toilers, he too of ten rushes in strikebreakers in the form of commercial cultures. When this is done, what a sorry spectacle we have-one or two strikebreakers pitted against billions and billions of strikers! The newcomers in a strange unnatural surrounding, the normal microbe in an abode in which they have lived for many generations. Hence, it does not require great prophetic instinct to foretell which will be victorious. The vendor of commercial cultures understands this; therefore, he furnishes the farmer with directions as to how his soil should be treated before the strikebreakers are added. When these directions are carefully followed, the conditions in the soil are made acceptable to the natural inhabitants thereof with the result that they resume their labors. The crops increase and the farmer goes about singing praises of the new panacea which he recommends to all his neighbors, and so the trade goes on.

Numerous concerns claim to have produced cultures which have been bred up to a high efficiency. This may be true as long as the organisms are grown under artificial conditions, but when thrown into competition with the natural hordes of the soil it is doubtful if they can ever get the upper hand. The logical procedure, therefore, is to make conditions within the soil ideal for plant growth after which if the requisite organisms are not present inoculation may be resorted to.

How Inoculate?-Successful seed inoculation can be performed with fresh, properly prepared artificial cultures, but in many cases this has not proved successful, and in the majority of cases inoculation with soil known to be infected is to be preferred. The method suggested by the Illinois Experiment Station 
for large seeds, such as soybeans, is very satisfactory. The seeds are thoroughly moistened by a 10 per cent solution of glue and sufficient dry pulverized infected soil sifted on to absorb all of the moisture. The seed is shovelled over a few times. Such infected seed should be planted very soon or else spread out to dry to prevent mold action. Neither infected seed nor soil should be long exposed to bright sunshine, as this is very destructive to the bacteria.

Where the old plants are to be inoculated, a few hundred pounds of soll may be obtained from an old infected field spread on the new field and harrowed.

Dr. C. B. Lipman gives the following method of inoculating beans, and in a modified form it can be used for other legumes:

"Method Involving the Use of One Commercial Culture: - Prepare one-half barrel full of good loam soil (I50 pounds) with sufficient water to make about optimum moisture conditions. This soil can be kept in a shallow vat about a foot in depth or in some other convenient receptacle where it can be well aërated. Purchase one commercial culture from any of the commercial firms selling legume bacterial cultures, choosing a culture for beans of the variety desired. The amount usually sold in a culture for one acre is sufficient. Shake this up with a few quarts of boiled water. The shaking should be continued for about ten minutes to get all of the bacteria in suspension. Pour this suspension all over the surface of the soil in the vat and add to the solution about one-quarter of a pound of ordinary sugar per one hundred pounds of soil used in the vat. This should be distributed as evenly as possible through the soil and the latter thoroughly mixed with a spade or hoe, thus distributing both the sugar solution and the culture. After that the inoculated soil is to be kept in a warm place like a kitchen or a warm stable and the moisture content maintained at optimum until you are ready to use it for the inoculaiton of beans when they are planted. It is well to allow a period of two or three months for such incubation.

"At the end of the incubation period, or when getting ready to plant, shake up some of the inoculated soil with clean water for a 
few minutes as before to get a good suspension of the bacteria. Pour enough of this suspension over the bean seed in large tanks or similar receptacles to wet the seed thoroughly, but not enough to allow any excess of water. Then spread the bean seed out on a canvas in a thin layer in the shade. As soon as the seed is air-dry and will not stick, place in a planter and plant immediately. In cases in which only small quantities of seed are to be planted, the suspension need not be made, but the inoculated soil in small quantities can be mixed with the seed in the planter and allowed to drop with the beans as they are dropped from the machine, thus introducing the bacteria into the soil with every seed, or nearly so.

"Alternative Method.-Where it is not desired even to purchase one commercial culture, inoculation can also be carried out entirely successfully by obtaining soil from a garden in which beans have grown successfully for some years and using that soil for making up the soil suspension or for mixing with the seed as above described. In other words, this garden soil, which contains the necessary bacteria, will serve fully as well as the inoculated and incubated soil just described above. This is of course the simpler method to those who have access to garden soil which has produced beans successfully. Soils like this may also be obtained from old and more extensive bean fields, where successful beangrowing has been carried out. For small plots, such soil can be directly harrowed into the soil to be inoculated after being spread (about one bushel per acre) in moist condition on a cloudy or rainy day."

Hope of the Future.-The discovery of the legume bacteria and the learning of the conditions under which they fix atmospheric nitrogen has removed the nitrogen problem in so far as the legumes are concerned, as they can now be grown on soil devoid of nitrogen, provided they are properly infected and the soil is otherwise suited to their growth. But how about the non-legumes? Are there no organisms which will live in symbiosis with these and thus render them independent of soil nitrogen? A number of investigators have asked these questions and attempts have been made to answer them. The legume organisms have been 
grown on extracts of non-legumes with the hope of thus increasing their virulence. They have been brought in contact with starved non-legumes, and attempts have even been made to inoculate them into the root hairs of non-legumes, - but so far without success.

This, however, does not say it is impossible. The legume organisms have slowly evolved to their present condition. From what did this evolution start? Was it, as some have suggested, from the Azotobacter? If so, what were the conditions under which this mutual helpfulness has developed? Will not the future produce the Burbanks in bacteriological breeding? Who will solve this problem? When that day comes, as we all hope it will, the farmer will then inoculate his wheat or his beets, as he now does his legumes, care for them and let the tiny new creation in bacteriology look after the nitrogen supply! 


\section{CHAPTER XVI}

\section{LEGUMES AND SOIL FERTILITY}

It has been the experience of practical men from the earliest days of agricultural practice that legumes under appropriate conditions render the soil more productive. The farmers of ancient Rome understood that crops following beans, peas, and vetches were usually better than those following wheat or barley. During the middle of the nineteenth century it was considered proved that neither legumes nor non-legumes could use atmospheric nitrogen, yet experiments pointed to the conclusions that legumes possessed peculiar powers. We have seen that during the last quarter of the nineteenth century, it was learned that legumes associated with bacteria have the power of utilizing atmospheric nitrogen, whereas non-legumes must rely on the combined nitrogen of the soil. Today the best farmers see that the legume enters largely into their systems of rotation. They know that such a practice means bigger and better crops at least for a time. Some farmers grow legumes for a number of years on run-down soil, remove the entire crops, and for a few years get increased yield. They are confident that their soil is becoming richer in plant-food. If this is not true, why this increase? Surely alfalfa and other legumes are not a stimulant to the soil as is tea, coffee, or tobacco to the tired man. Let us examine some results obtained in carefully planned experiments for the answer.

Essential Elements.-We have seen that plants are composed of ten elements, each of which is absolutely essential to growth and seed formation. Only two-carbon and oxygenare secured from the air by all plants, only one-hydrogenfrom the water; the other seven are secured by all plants from the soil. One class of plants-the legumes-may, under appropriate conditions, obtain their nitrogen from the air. Six elements- 
phosphorus, potassium, magnesium, calcium, iron, and sulfurare obtained by all plants from the soil.

Plant-food Added by Legumes.-The majority of agricultural soils contain sufficient quantities of all these elements except nitrogen, phosphorus, and potassium. These are low in many soils and used by the growing plant in larger quantities than are any of the other elements obtained directly from the soil. Therefore, it becomes pertinent to ask: Can legumes maintain these elements in the soil in quantities sufficient for maximum crop production? Phosphorus and potassium are obtained by all growing plants only from the soil. It is, therefore, evident that legumes cannot maintain the phosphorus and potassium since the quantity within the soil must of necessity be reduced with each crop removed, the extent depending upon the kind and size of the specific crop. Hence, nitrogen is the only element which we can hope to return by legumes. Usually this is the element limiting crop production as it is found in the soil in smallest quantity and removed by the plants in larger quantities than either phosphorus or potassium. Moreover, large quantities of this element are at times leached from the soil, whereas the loss of the others is comparatively small. It is, therefore, of the greatest importance that nitrogen be supplied to the soils in sufficient quantities for crop production and in the cheapest available form.

The total quantity of the three elements-nitrogen, phosphorus, and potassium-found in an acre-foot of two Utah agricultural soils, assuming one acre-foot to weigh $3,600,000$ pounds and the rate of removal by crop, is given on opposite page.

Both soils contain an abundance of potassium, but the supply of phosphorus and nitrogen is much lower. A study of these results shows that a 50-bushel crop of wheat each year for fiftyone years would remove the equivalent of the total quantity of nitrogen in the Greenville soil to a depth of one foot, while a similar crop on the Nephi farm would accomplish this in just thirty-nine years. It would, however, require a 50-bushel crop I69 years to remove the phosphorus from the Greenville soil and 524 years to remove it from the Nephi soil, whereas the 
potassium in each soil is sufficient for over 1,000 years. Of course, a crop would never remove all the nitrogen or phosphorus from a soil, but in actual practice the elements are slowly removed and the crop yields reduced each year until a certain minimum is reached. When crops can no longer be produced economically then the owner abandons his soil, moves on to virgin soils, or if it be in an old district he resorts to the expensive commercial fertilizer. However, the illustration is sufficiently accurate to clearly indicate that nitrogen is the limiting factor in so far as soil fertility is concerned in both of these soils. This is true of the great majority of soils; therefore, an increased nitrogen supply in them means an increased yield. This principle is one of the fundamentals of soil fertility.

\begin{tabular}{l|c|c|c}
\hline & Nitrogen & Phosphorus & Potassium \\
\hline $\begin{array}{l}\text { Greenville Farm (Logan, Utah) } \\
\text { Pounds per acre }\end{array}$ & 4,904 & 2,700 & 60,560 \\
Total removed in a 50 bushel & & & \\
wheat crop & 96 & 16 & 58 \\
No. of 50-bushel crops wheat & 51 & 169 & 1,045 \\
Total removed in 20 tons & 100 & 18 & 157 \\
sugar beets & 49 & 150 & 380 \\
No. 20 ton crops beets & 3,744 & 8,388 & 87,840 \\
Nephi Farm (Nephi, Utah) & 39 & 524 & 1,515 \\
Pounds per acre & & & \\
No. 50-bushel crops wheat & &
\end{tabular}

Nitrogen.-Nitrogen exists in the atmosphere in inexhaustible quantities. Every square yard of land has seven tons of nitrogen lying over it, or if the quantity covering one acre could be made into nitrates it would be worth as a fertilizer $\$ 125,000,000$. Now we have seen that the legumes-peas, beans, alfalfa, clover, and vetches-when properly inoculated have the power of feeding on this vast ocean of atmospheric nitrogen, whereas the nonlegumes-barley, wheat, oats, etc.-must depend upon the supply within the soil. The farmer must take advantage of this fact 


\section{I74 BACTERIA AND SOIL FERTILITY}

to supply nitrogen to his soils as commercial fertilizers cannot be economically used for the production of many crops. This may be seen by the following:

The nitrogen in a 50-bushel wheat crop would cost $\$ 14.40$, twenty tons of sugar beets $\$ 15$, and one ton of alfalfa hay $\$ 7.50$, if bought as a commercial fertilizer. We know legumes can use nitrogen from the atmosphere, but will they draw on this nitrogen while there is a supply in the soil? Or will they follow the line of least resistance and turn to the atmosphere only when nitrogen is lacking in the soil? If they do, they must first drain the soil of its valuable nitrogen and thus leave it no richer than it was before the legume was grown upon the soil. Let us see.

Rothamsted Rotation.- Crop rotations in which the legumes enter have been practiced for centuries, but the oldest system on which we have accurate information is the one on Agdell Field at the Rothamsted Experiment Station. This system was inaugurated in 1848 and is still being carefully followed. It consists of a 4year rotation as follows:

First year-Swedish turnips (rutabagas)

Second year-barley

Third year-clover or beans

Fourth year-wheat

Still another system has been running parallel and similar to this, except that fallow cultivation is practiced in the third year instead of growing a legume. The average yields for 20-year periods are given on page 175 . These systems are of special interest to western farmers, for if we substitute sugar-beets for turnips and alfalfa or peas for the clover and beans we have nearly an ideal rotation for western soils.

Even where the legume was used in the system there had been a decline in the yield. The yield of the turnips during the first twenty years was 5,264 pounds, the second 1,723 , and the third only 967 pounds, thus showing a decrease of about five-sixths the original in sixty years. 


\begin{tabular}{|c|c|c|c|c|c|c|}
\hline \multirow{2}{*}{ Crop } & \multicolumn{3}{|c|}{$\begin{array}{c}\text { Legumes-Yield } \\
\text { (20-year Periods) }\end{array}$} & \multicolumn{3}{|c|}{$\begin{array}{c}\text { Fallow-Yield } \\
\text { (20-year Periods) }\end{array}$} \\
\hline & $\begin{array}{c}\text { Ist } \\
1848-68\end{array}$ & $\begin{array}{c}\text { 2nd } \\
1868-88\end{array}$ & $\begin{array}{c}3^{r d} \\
1888-1908\end{array}$ & $\begin{array}{c}I s t \\
1848-68\end{array}$ & $\begin{array}{c}2 n d \\
1868-88\end{array}$ & $\begin{array}{c}3^{r d} \\
1888-1908\end{array}$ \\
\hline $\begin{array}{l}\text { Turnips } \\
\text { Roots (lbs.) } \\
\text { Leaves (lbs.) }\end{array}$ & $\begin{array}{r}5,264.0 \\
600.0\end{array}$ & $\begin{array}{r}I, 723.0 \\
447.0\end{array}$ & $\begin{array}{l}967.0 \\
242.0\end{array}$ & $\begin{array}{r}5,785.0 \\
629.0\end{array}$ & $\begin{array}{r}3,067.0 \\
538.0\end{array}$ & $\begin{array}{r}2,502.0 \\
458.0\end{array}$ \\
\hline $\begin{array}{l}\text { Barley } \\
\text { Grain (lbs.) } \\
\text { Straw (lbs.) }\end{array}$ & $\begin{array}{r}38.0 \\
2,373.0\end{array}$ & $\begin{array}{r}22.5 \\
\mathrm{I}, 496.0\end{array}$ & $\begin{array}{r}13.7 \\
1,172.0\end{array}$ & $\begin{array}{r}37.0 \\
2,244.0\end{array}$ & $\begin{array}{r}22.8 \\
I, 489.0\end{array}$ & $\begin{array}{r}15.9 \\
\text { I,I } 72.0\end{array}$ \\
\hline $\begin{array}{l}\text { Wheat } \\
\text { Grain (bu.) } \\
\text { Straw (lbs.) }\end{array}$ & $\begin{array}{r}29.6 \\
3, I 69.0\end{array}$ & $\begin{array}{r}21 . I \\
2,082.0\end{array}$ & $\begin{array}{r}24.3 \\
2,455.0\end{array}$ & $\begin{array}{r}34.5 \\
3,761.0\end{array}$ & $\begin{array}{r}23.2 \\
2,420.0\end{array}$ & $\begin{array}{r}23 \cdot 5 \\
2,412.0\end{array}$ \\
\hline
\end{tabular}

The results with the barley are no better, for there is a decline from the fair yield of 38 bushels per acre during the first period to only 13.7 during the third. The wheat which followed the legume in the rotation, and hence occupied the most favored place in the system, shows a decrease of 5.3 bushels. Even the yield of clover has decreased, as from 1850 to 1874 the average yield was 4,165 pounds, while from I 882 to 1906 the yield was only 1,246 pounds. In reality the decline in the yields is no greater where fallow cultivation is practiced than where legumes enter. Both systems strongly testify that rotation is not maintaining the productive powers of this soil. And the evidence is strong that the legume gets no more nitrogen from the air than that which is removed with the plant. Otherwise, we should expect better results in the legume system than in the fallow system.

Nitrogen Obtained from Atmosphere by Legumes.-That the alfalfa when grown on fertile soil and the crop removed does not increase the nitrogen of the soil is seen from experiments conducted by Dr. Hopkins at the University of Illinois. The experiments were made possible by the fact that many of the Illinois soils do not normally contain the symbiotic nitrogen-fixing 


\section{I76 BACTERIA AND SOIL FERTILITY}

bacteria which make it possible for the alfalfa to obtain nitrogen from the air. This being the case, a field was selected which had not grown alfalfa and which did not contain the symbiotic nitrogen-gathering bacteria. This was seeded to alfalfa and one-half of it inoculated with the legume microörganism. To some of the plots were added lime and phosphorus to make certain that these were not the limiting factors. The results obtained are given below:

\begin{tabular}{l|l|c|c|c}
\hline \hline $\begin{array}{c}\text { Plot } \\
\text { No. }\end{array}$ & \multicolumn{1}{c|}{$\begin{array}{c}\text { Treatment } \\
\text { Applied }\end{array}$} & \multicolumn{2}{|c|}{$\begin{array}{c}\text { Pounds in Crop } \\
\text { Pounds Nitrogen } \\
\text { Fixed by Bacteria }\end{array}$} \\
\cline { 2 - 3 } & Dry Matter & Nitrogen & \\
\hline I a & None & $\mathrm{I}, \mathrm{I} 80.0$ & $21.8 \mathrm{I}$ & \\
Ib & Bacteria & $2,300.0$ & 62.04 & 40.23 \\
& Lime & $\mathrm{I}, 300.0$ & 26.20 & \\
2a & Lime, bacteria & $2,570.0$ & 68.02 & 41.82 \\
& Lime, phosphorus & $1,740.0$ & 35.40 & \\
3a & Lime, phosphorus, bacteria & $3,290.0$ & 89.05 & 53.65 \\
\hline
\end{tabular}

It is evident from these results that the alfalfa has obtained from forty to fifty-three pounds of nitrogen from the air, depending upon the treatment. There was slightly more than onethird as much nitrogen in the alfalfa crop from the uninoculated than in the inoculated. Therefore, it is evident that the alfalfa in these plots had obtained one-third of its nitrogen from the soil and two-thirds from the air. Now, nitrogen is required by the root for its growth as well as for the growth above the ground, and we have every reason for believing that the root also would obtain it in the same proportion from air and soil as did the hay crop.

Distribution of Nitrogen in Legumes.-If we examine dry matter and total nitrogen occurring in the roots and stalks of alfalfa we should be able to decide whether more nitrogen is being returned to the soil in the roots and residues than is removed from the soil by the growing plants. 
The results for this comparison have been obtained from Illinois and Delaware experiments and are tabulated below:

\begin{tabular}{l|c|c|c}
\hline \multicolumn{1}{c|}{ Legume } & $\begin{array}{c}\text { Dry Matter per } \\
\text { Acre (lbs.) }\end{array}$ & $\begin{array}{c}\text { Nitrogen per } \\
\text { Acre (lbs.) }\end{array}$ & $\begin{array}{c}\text { Per cent of Total } \\
\text { Nitrogen in Tops }\end{array}$ \\
\hline Sweet Clover & $9,029.0$ & 174.0 & \\
$\quad$ Tops & $3,784.0$ & 54.0 & 76.0 \\
$\begin{array}{l}\text { Roots and residues } \\
\text { Crimson Clover }\end{array}$ & $4,512.0$ & 103.0 & \\
Tops & $2,022.0$ & 41.0 & 70.0 \\
Roots & $2,267.0$ & 54.8 & 60.0 \\
Alfalfa & $1,980.0$ & 40.4 & \\
Tops & & & \\
Roots & & \\
\hline
\end{tabular}

In the clover three-fourths of the total nitrogen is found in the plant above ground and only one-fourth in the roots, whereas alfalfa shows a greater proportion in the roots- 40 per cent. This represents the proportion for the first-year growth for alfalfa, and it is not likely that in the older plant this proportion of the total nitrogen would be maintained in the roots. Hence, it is quite certain that if only two-thirds of the total nitrogen of the plant is obtained from the air the quantity returned to the soil with the roots and plant residues does not exceed that removed from the soil by the growing plant. This would give no increase in soil nitrogen from the growing of a legume where the entire crop is removed even though the roots are allowed to remain and decay. Yet we find farmers who remove the crop and later the roots as a nuisance from the soil and even then expect an increase in their soil nitrogen.

Legumes Feed on Nitrates.-It is, therefore, rather certain that the legumes, where the crop is harvested, does not increase the soil nitrogen of the fertile soil of Illinois and other soil fairly rich in nitrogen. But what will happen on the arid and semi-arid soil where nitrogen in many cases is the limiting element of crop production and is present in much smaller quantities than it is in the soils on which the experiments considered were conducted. 
Experiments conducted at the Utah Experiment Station during twelve years have demonstrated that even on soils poor in nitrogen the legume first feeds upon the combined nitrogen of the soil. We have seen that plant residues and other complex nitrogen compounds found in the soil are transformed by bacteria into ammonia, and this in turn by another class of bacteria into nitric nitrogen, and it is mainly on this nitrogen that the growing plant feeds. The quantity of this occurring in the soil at different periods under different plants, as measured at the Utah Experiment Station, and the average for twelve years, are given in tabular form below. These results are stated as pounds of nitric nitrogen per acre-foot of soil to a depth of six feet.

\begin{tabular}{l|c|c|c|c}
\hline \multirow{2}{*}{ Crop } & \multicolumn{3}{|c|}{ Season } & \multirow{2}{*}{ Average } \\
\cline { 2 - 4 } & Spring & Midsummer & Fall & \\
\hline Alfalfa & 22.3 & I 5.8 & 32.8 & 23.6 \\
Oats & 35.7 & I4.I & 20.6 & 23.5 \\
Corn & 24.8 & I8.9 & 22.0 & 21.9 \\
Potatoes & $8 \mathrm{I} . \mathrm{I}$ & 60.8 & 54.2 & 65.3 \\
Fallow & $8 \mathrm{I} .5$ & 53.6 & 62.6 & 65.9 \\
& & & & \\
\hline
\end{tabular}

The legume removes the nitric nitrogen from the soil equally as fast as does the non-legume. Yet this soil was well inoculated with the symbiotic bacteria which undoubtedly assisted the alfalfa in obtaining free nitrogen from the air when needed, but not until the soluble nitrogen had been drained from the soil to its full extent, as shown by the fact that alfalfa soil never contains more than oat and corn land and is very poor as compared with potato and fallow soil.

Nitrification in Soils.-It may be argued that the small quantity of nitric nitrogen in the alfalfa soil is due to low nitrification as nitrates are not needed by the legume and hence not produced. This conclusion is not warranted by the facts in the case, as may be seen from the results obtained where nitrification was measured. These also are the average results extending over a number of years and obtained at the Utah Experiment Station. 


\begin{tabular}{l|c|c|c|c}
\hline \multirow{3}{*}{ Crop } & \multicolumn{2}{|c|}{$\begin{array}{c}\text { Milligrams Nitric Nitrogen Produced in } 100 \text { gms. Sozl in } \\
\text { 2I Days }\end{array}$} & \multirow{2}{*}{ Average } \\
\cline { 2 - 4 } & Spring & Midsummer & Fall & \\
\hline Alfalfa & 3.15 & 7.48 & 3.08 & 4.56 \\
Oats & 2.40 & 4.00 & 3.00 & 3.13 \\
Corn & 2.18 & 3.50 & 1.48 & 2.38 \\
Potatoes & 3.00 & 15.55 & 5.60 & 8.04 \\
Fallow & 1.30 & 5.50 & 2.48 & 3.09 \\
\hline
\end{tabular}

The quantity of nitrates produced in the alfalfa soil is greater than that produced in either the oat, corn, or fallow soil. This increased nitrification is also noted in alfalfa soil the year after the alfalfa is plowed under. This accounts in a measure for the increased yield obtained the year following the plowing of an alfalfa field. Therefore, we can conclude that alfalfa stimulates ammonifiers and nitrifiers so they render available faster the nitrogen of the soil. This would indicate that the legume depletes the soil of its nitrogen more readily than the non-legume, as it is the nitrogen already combined in the soil on which the nitrifying organisms act. Hence, we must conclude that alfalfa not only feeds closer on the soluble nitrates of the soil, but it also makes a greater drain upon the insoluble nitrogen of the soil by increasing its nitrifying powers and would, therefore, deplete the soil if the entire crop were removed more readily than would other cropsa conclusion which is borne out by the direct analysis of the soil. The analysis of a great number of Utah soils which have grown various crops, some of them having been into alfalfa or wheat for upward of thirty years, revealed the fact that almost invariably alfalfa soil contained less total nitrogen than did wheat soil. The average for a great number of determinations made on alfalfa soils was 7,232 pounds per acre of total nitrogen, while the average for a great number of wheat soils was 7,398 pounds.

These are average results from numerous determinations made on adjoining alfalfa and wheat soil, and they clearly indicate that 
in ordinary farm practice the alfalfa is making just as heavy a drain upon the soil nitrogen as is the wheat.

Hence, from a consideration of the yields obtained in crop rotation, the relative quantities of nitrogen obtained from the atmosphere and the soil by the alfalfa, the feeding and stimulating effect of the alfalfa upon nitrate production, and finally the actual quantity of total nitrogen remaining in the soil after wheat and legumes, we must conclude that the legume does not increase the nitrogen of a common agricultural soil-even in the arid region where the nitrogen is low-when the entire crop is removed.

This conclusion, however, does not mean that crop rotation should not be practiced, for there are many reasons why crop rotation commends itself to the careful farmer, but it must not be used and the legume removed with the intention of maintaining soil fertility. This may appear to be an unfortunate conclusion, but it is just the reverse, and if its teachings be heeded it means a fertile soil and an economic gain to the farmer from the system of farming which it requires him to adopt.

How Maintain Soil Nitrogen?- There are two practical methods of maintaining the nitrogen content of the soil. First, planning systems of crop rotations with legumes, the legumes being plowed under and allowed to decay, thus furnishing nitrogen to the succeeding crop. Second, practicing a combined system of crop rotation and livestock farming.

Three tons of alfalfa contain I 50 pounds of nitrogen, all of which we can assume came from the atmosphere. Assuming the quantity found in the roots as coming from the soil, this is the equivalent of the nitrogen found in the grain and straw of seventy-five bushels of wheat. If the alfalfa is plowed under some of the nitrogen may be lost to the growing plant in the processes of decay and leaching, but that the total nitrogen of the soil may actually be increased by the turning under of the legume is certain from field experiments.

The Dominion of Canada Experiment Stations grew mammoth clover for two successive seasons on a soil very low in nitrogen. The two cuttings of mammoth clover with all the residues were 
turned under each year with the result that the soil gained as an average 177 pounds per acre of total nitrogen, which is the quantity of nitrogen found in three 40-bushel crops of wheat, provided the straw is returned to the soil. Work on the soil of the Nephi Experiment Station (Utah), with a rotation of wheat and peas where the peas were plowed under, showed a gain in total nitrogen of 240 pounds in four years. That is, in addition to furnishing the nitrogen required by the wheat crop the peas had added to the soil an average of sixty pounds of nitrogen per year.

The second method of maintaining the nitrogen and organic matter of the soil-the combined rotation and livestock methodis the more practical, and if systematically practiced will not only maintain the nitrogen of the soil but will prove of great economic value to the individual following it. It consists of a rotation in which the legume plays a prominent part. The legume to be fed and all the manure returned to the soil. This would mean the selling from the farm the hay crop in the form of butter, milk, or beef which carries from the soil only a fraction of the nitrogen stored up by the legume. Moreover, it brings for the producer much greater returns than does the system in which the legume is completely removed from the soil.

It must be remembered, however, in this system that only threefourths of the total nitrogen of the feed is recovered in the dung and urine. So that in place of three tons of alfalfa adding 150 pounds of nitrogen to the soil from the air, it would add only I I 2 pounds-and this where all of the liquid and solid excrements are collected and returned to the soil. However, where the alfalfa is to be fed and the manure returned to the soil the legume can occupy a much longer period in the rotation, and that with greater economy than where the legume is to be plowed under directly.

Hence, we find that if these principles which have been established for soils even low in nitrogen be systematically applied to the soil it will result in greater revenue from an increased livestock industry and will maintain the soil rich in nitrogen and organic matter in place of depleting it of its stored-up nitrogen, as is so often the case with the present methods. 


\section{CHAPTER XVII}

\section{CELLULOSE FERMENTATION}

Every farm boy knows that a stick of timber placed in the soil rots. If he be an observing lad he knows that it is at the surface of the soil that the decay is most active, and that the speed of the decay varies with different wood and the soil in which it is placed. It is far different in a light loose silt than it is in a heavy tight clay. If he be of an inquisitive nature he has pulled from the decaying wood the loose, light, pithy substance and wondered why this change. What is the cause? Are such agencies always injurious, or may they at times be beneficial? If at times beneficial, when and where? Why does the post decay more rapidly at the surface than it does within the soil? And how does the farmer hope to prevent this decay by charring or tarring the post?

What is Cellulose?-The post is composed mainly of cellulose, and cellulose next to water is the most abundant substance in the vegetable kingdom. It is to the vegetable kingdom what the bones are to the animal. It is especially abundant in the roots, steams, and leaves of mature plants. In hay and coarse fodders it constitutes from 30 to 40 per cent of the dry matter. Cotton, linen, and paper are examples of nearly pure cellulose. The term cellulose is used to designate a group of substances ranging from the tender hemicellulose of the young green plants to the complex resistant material of wood. In its natural condition it is usually interlaid with gum-like substances. Bacteria may digest these, leaving the more nearly pure cellulose, as is the case in the retting of flax, or they may digest the true cellulose.

Cellulose is peculiar in a number of ways: (I) It is very widely distributed in the plant world, special plant tissues at times containing as high as 90 per cent cellulose. It is very rare in 
the animal kingdom. (2) It is composed of the same elementscarbon, hydrogen, and oxygen-as the sugars. Moreover, many of the sugars contain these elements in the same proportion as does the cellulose. (3) Cellulose has no nutritive value for man, yet one of the dietetic errors of modern man is that his food does not contain sufficient quantities of it. It gives to the food bulk, and hence forms leverage on which the intestines can act. It is reported that sawdust and wood shavings, which are largely cellulose, were used by the Germans in the late war as a cattle food and in war breads. Cattle, due to the bacterial flora of the alimentary canal, may utilize some cellulose, but it is doubtful if man would be nourished by its use. (4) Cellulose is insoluble in all of the common solvents such as alcohol, ether, and water. If treated with sodium hydrate, it will dissolve in carbon bisulfide, and if the resulting yellowish liquid is squirted through fine holes into acidulated water we have fine threads of artificial silk. (5) Plants secrete a digestive ferment which will break down cellulose. This is especially true of some fungi, bacteria, and germinating seeds. No animals secrete such a ferment; hence, when cellulose is digested by animals it is due to the bacteria which they harbor in their intestines.

Cellulose in Soil.-The organic matter of the soil originates from the plants-either those which have grown upon the soil or those which have been carried there by various processes, principally as manures. Where wheat is grown upon the arid soils of western America and harvested with the header or combined harvester from one to two tons of roots, straw, and chaff may be left upon the soil, depending upon the size of the crop and the method used in harvesting it.

Assuming that one ton of straw is left, it would carry back into the soil ten pounds of nitrogen, two pounds of phosphorus, and ten pounds of potassium, as well as $I, 700$ pounds of dry matter, about 50 per cent of which is cellulose. 'That is, one ton of straw carries to the soil approximately 850 pounds of cellulose. When alfalfa and plant residues are returned to a soil, proportionately smaller, but appreciable, quantities of cellulose are being 
returned to the soil. The quantity carried to a soil with manure may vary from a few per cent to one-half the total dry weight, depending on the age, kind of manure, and litter used in bedding the animals. Now, where the farmer burns straw and other cellulose containing material on the soil, the phosphorus and potassium would all be left in the ash. Most of the nitrogen and all the cellulose would be lost. But when the straw is left to decay, it serves as food for cellulose ferments and incidentally changes the chemical and physical aspects of the soil.

Early Observations. - That carbon passes through a definite cycle from the solid organic tissues of plants to the gaseous form of the atmosphere has been known for a long time, but it was usually thought of as passing from the solid complexes to the gaseous compounds through its direct combination with oxygen at a high temperature. In fact, this was considered as being the only method until Pasteur pointed out that there were other means. He considered it as being brought about by molds. Later Mitscherlich (1850) observed that when moist potatoes decay the cell wall is dissolved and the starch gradually passes out. This he considered due to the action of microörganisms, but nothing was done to show that it was the work of any species until about fifteen years later when Trécul isolated an organism which had the power of decomposing young plant tissues and which was stained blue by iodine. To this organism he gave the name amylobacter The organism he claimed had the power of decomposing cellulose with the formation of butyric acid, carbon dioxid, and hydrogen. As all of his work was carried on with plant tissues, however, it left a question as to whether the amylobacter had actually decomposed cellulose or only some of the nearly related compounds.

Some of the earliest work done to determine the change through which cellulose passes in soil was that of Hoppe-Seyler who commenced his experiments by collecting and analyzing the gases given off from soils and swamps. These he found to consist mainly of carbon dioxid and methane. Later he carried out laboratory determinations by placing $25.773 \mathrm{gm}$. of filter paper 
in $\mathrm{r}, 000 \mathrm{cc}$. of water and inoculated with mud. The containers were so arranged that the gaseous products were collected over mercury. These he kept at room temperature for four years. During the first year there was considerable gas evolved, but the evolution gradually became slower, until at the end of four years the evolution of gas had practically ceased. An analysis showed that $15 \mathrm{gm}$. of the cellulose had been decomposed with the formation mainly of carbon dioxid and methane. He was unable to find any of the true sugars, although he thought it possible that there were some of the dextrin compounds in the solution. When air was excluded he found that there was a greater production of methane and a smaller production of carbon dioxid. From his work he considered that the reaction proceeded in two stages. First, the cellulose is made to take up water and form a six-carbon sugar. Second, from this carbon dioxid and methane were produced, or perhaps acetic arid was first formed and then carbon dioxid and methane produced from this.

Later workers studied the decomposition of cotton, manure, straw, and filter paper, and always with the same results-that there was formed considerable quantities of carbon dioxid, other gases, and various acids. The quantity and kind of each varied with the substance which was fermenting and the material which was added to it.

Discovery of the Organisms.-Although the evidence was clear that cellulose decomposed in soil with the production of gases and acids, nothing definite was known concerning the causative organism until I 895 . At this time a Russian investigator started to study the process, and after years of careful work obtained two anaerobic or ganisms which decomposed cellulose-one with the formation of hydrogen, the other methane or marsh gas.

Most individuals have noted that on stirring water which has stood some time over vegetation, bubbles come to the surface. If this gas is collected and ignited it burns. These anaerobic microörganisms are probably the bacteria which bring about this change, but the true cellulose ferments of soil were not obtained until re- 
cently when Kellerman and McBeth isolated thirty-six species from different sources. These were much more active than those studied by earlier workers. They were all rod-shaped organisms varying in length from .8 to $3.5 \mu$. Involution forms have been observed for only three species. Five species have been found to produce spores. Twenty-seven species are motile; of these, seven are pseudomonas and twenty are bacilli. A few are faculative

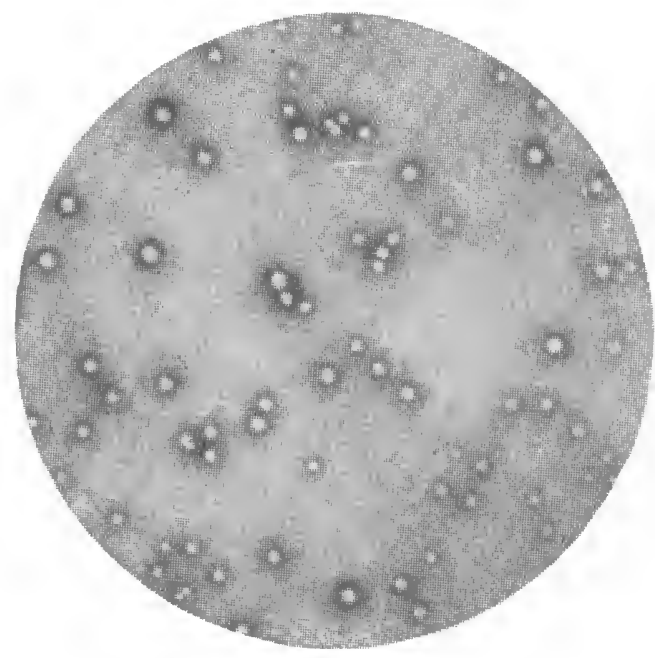

Fig. 36.-Colonies of cellulose ferments. (After McBeth.)

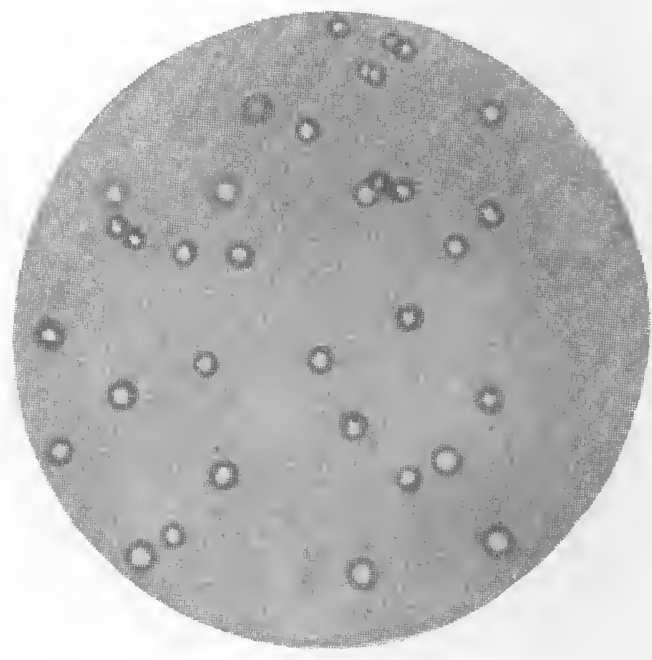

anaerobes, but most are true aerobes. The optimum temperature lies between $26^{\circ}$ and $33^{\circ} \mathrm{C}$. They grow rapidly on solid media such as beef agar, gelatin, starch, and potato. Nineteen species liquefy gelatin. They rapidly decompose cellulose and other carbohydrates with the production of acids, but none of the organisms so far studied produce a gas.

Products.-Cellulose when treated with dilute acid takes up water and falls to pieces. There results first the complex dextrins, which in turn break into the sugar maltose and then into grape sugar. This when oxidized yields alcohol; hence, it is possible for the chemist to change sawdust into sugar and then alcohol. Likewise, the cellulose ferments change the woody tissues of plants into dextrins, sugar, alcohol, and finally into acids. These products, in turn, are used by other microörganisms in their metabolism. During this tearing-down process the microbe 
is obtaining energy required to accomplish its tasks. Hence, cellulose is to these microbes what coal is to the engine.

Function.-It may be well to call attention to the great part played by these microörganisms in returning carbon to the atmosphere. 'They are especially valuable in decomposing the cellulose which passes off in the sewage. In septic tanks there are millions of these organisms busy changing the most resistant organic mat-
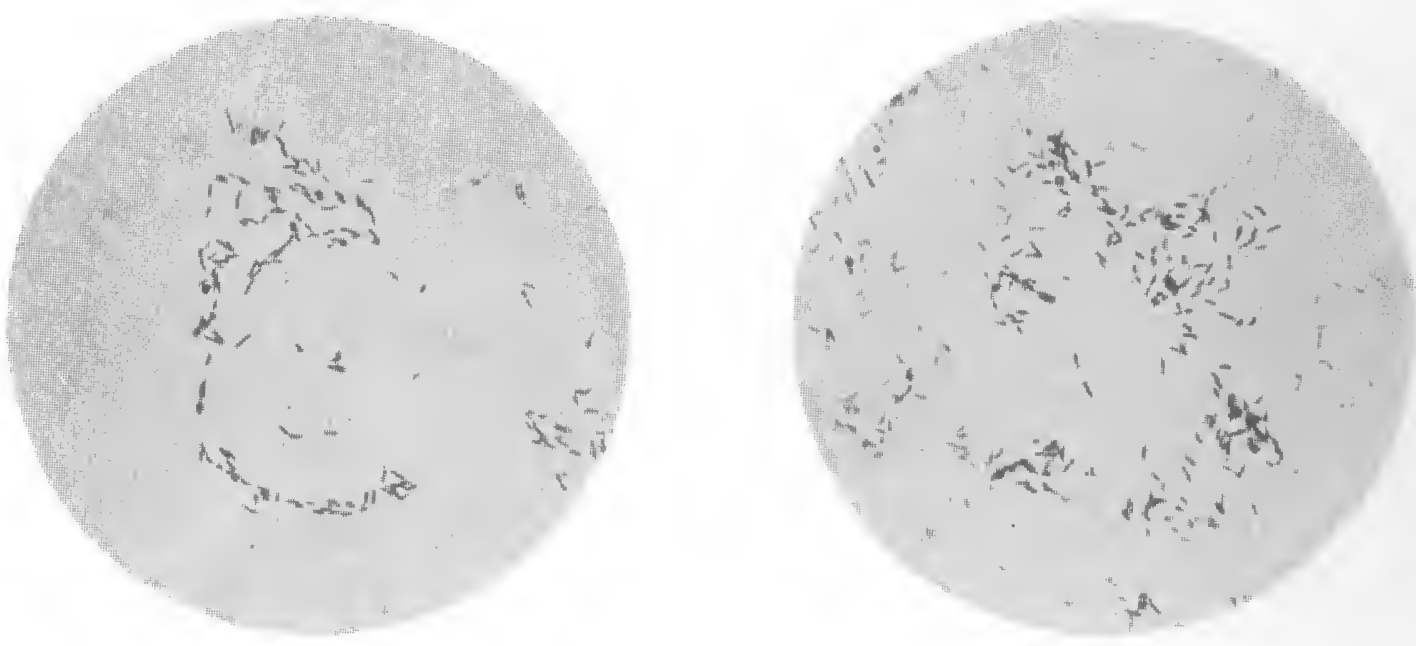

Fig. 37.-Cellulose ferments. (After McBeth.)

ter into gaseous products, and today many large cities depend upon them for the disposal of their waste. They also take a great part in the purification of a city's water supply. Omelianski considers them of prime importance in the formation of soil humus, for he writes, "It is possible that a general reaction of this sort forms the basis of the universal processes of humification, that is, the gradual transformation of organic substances into mixture of brown and black substances with a high content of carbon, such as is characteristic of fossil coals. But whatever the mechanisms of these transformations, the active participation of microörganisms in the latter cannot be denied."

The cellulose bacteria break the plant residues into less complex organic compounds which are fermented by other microörganisms with the generation of large quantities of organic acids. These would react with the minerals of the soil and render them 
available to higher plants. This is very likely the explanation of the beneficial results obtained when raw rock phosphate and stable manure are used on phosphorus-poor soil. Microörganisms decompose the soil cellulose producing acids which react with insoluble phosphorus rendering it available to the higher plants. The production of acids may at times, however, become excessive, giving rise to the sour humus of moors and heaths.

It is well-known that the fermentation processes in the soil resulting in the decomposition of organic matter may give rise to large quantities of carbon dioxid, methane, and hydrogen. The hydrogen and methane do not all pass into the atmosphere, but according to the researches of recent investigators furnish energy to numerous other soil microörganisms, the importance of which remains almost wholly for future workers to develop. The first work on this subject was done by Immendorff, who in 1892 found that hydrogen and oxygen may be made to unite under the influence of soil. He found that the oxidation of hydrogen was brought about only by normal soil and not by soil previously treated with chloroform vapor. This observation remained unnoticed until recently when two papers appeared-one by Kaserer and the other by Solmgen-which throw considerable light on this phase of carbon and hydrogen transformation. They used an inorganic solution containing dipotassium phosphate, ammonium chlorid, magnesium sulfate, sodium bicarbonate, and a trace of ferric chloride. This they inoculated with a small quantity of soil and confined in an atmosphere consisting of a mixture of hydrogen, oxygen, and carbon dioxid. Growth took place, and the hydrogen disappeared. The presence of a small quantity of carbon dioxid appeared to be necessary for the development of the microörganisms, and it would appear that like the nitrifying bacteria they can produce bacterial protein in inorganic solutions, deriving their carbon from carbon dioxid. This reaction, according to Lipman, is of great significance in agriculture, for a great loss of energy is prevented by the bacterial oxidation of hydrogen produced in the deper layers of the soil by anaerobic ferments. It also partly counteracts the rapid mineralization of or- 
ganic materials in that it leads to the formation of complex compounds from carbon dioxid, hydrogen, and oxygen.

The cellulose ferments also perform other direct functions in the soil, as for instance in the liberating of plant-food which is bound up in the residues of plants. Heinze has very recently ascribed to bacterial activities much of the benefits obtained from summer fallowing. In quantitative studies he found them to be more numerous in fallow soil than in cropped soil, and he thinks it is due to their activities in rendering the cellulose more suitable as a carbon supply for the Azotobacter that causes the increase of soil nitrogen in fallow land noted by a number of recent workers. Hence, they are the organisms which decompose the cellulose of straw so it can be utilized by the Azotobacter in the fixation of atmospheric nitrogen. Now, investigations have shown that under suitable conditions the Azotobacter may fix $325 \mathrm{mgm}$. of nitrogen for every $100 \mathrm{gm}$. of straw decomposed. At this rate there would be a gain of seven pounds of nitrogen for every ton of straw utilized. This, in addition to other beneficial effects, the farmer is losing when he burns his straw. 


\section{CHAP'TER XVIII}

\section{INFLUENCE OF SOIL ALKALI ON BACTERIA}

Soluble salts of ten accumulate in the soil of regions where the annual rainfall is less than twenty inches. When the concentration of the salt becomes sufficient to be injurious to plants we

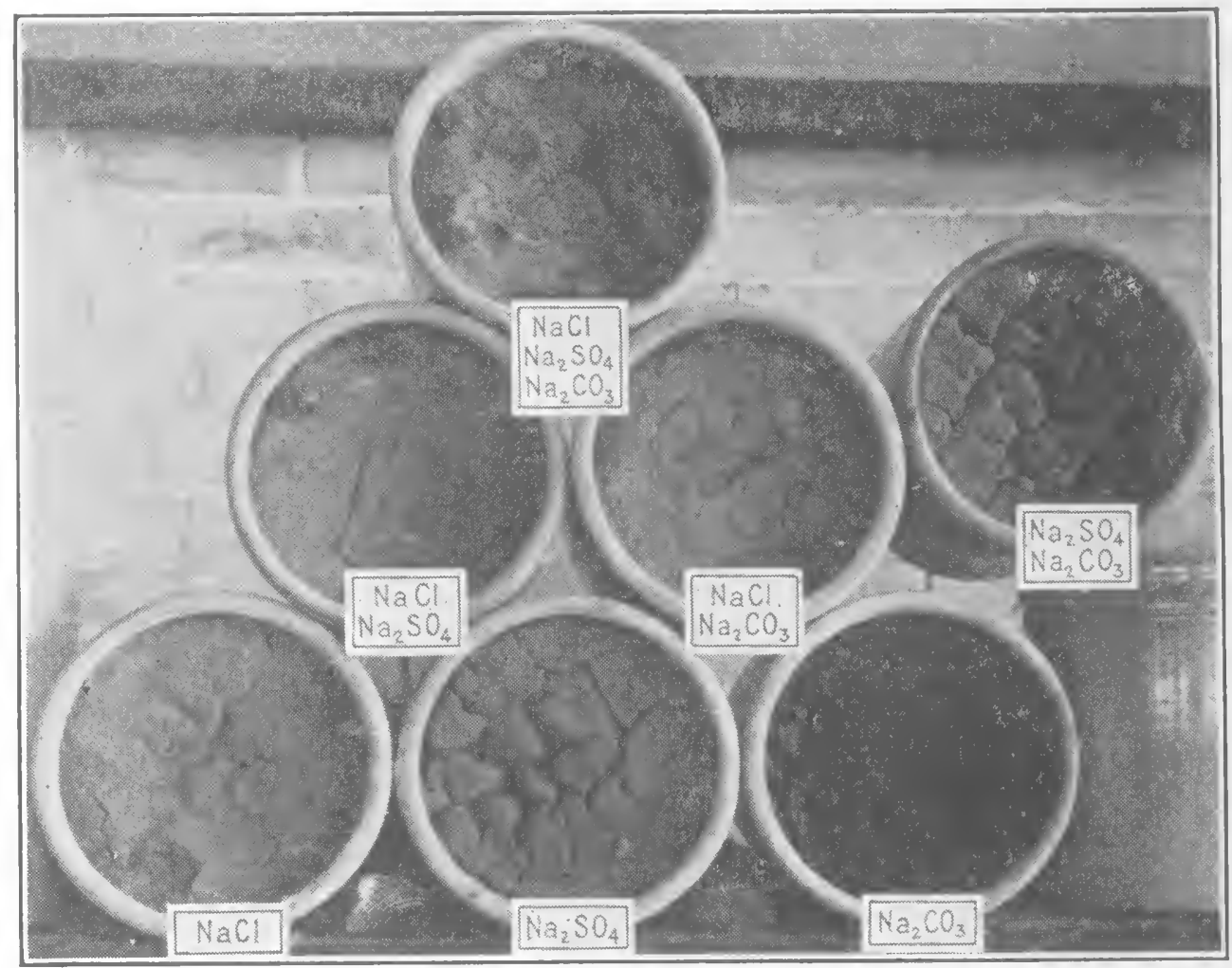

FIg. 38.-Alkali soils. Produced by the addition of various soluble salts to a productive soil.

have what is known as alkali soil. The trained eye readily recognizes such a soil from its color and structure as well as from the kind and condition of vegetation growing upon it. If the visible vegetation is so profoundly modified, we involuntarily ask: How does it influence the microflora? Do the microörganisms disappear from such a soil, or are they fewer in number? Does alkali soil contain a special microflora? 
Kinds of Alkali.-The main injurious constituents in alkali soils are sodium chlorid or common salt, sodium sulfate or Glauber salt, sodium carbonate, and less frequently sodium nitrate. Soils which have been the bed of seas or lakes contain in addition to the above constituents magnesium chlorid or bittern, magnesium sulfate or epsom salts, and calcium sulfate or gypsum. Where there is a large quantity of any or all of the above salts except sodium carbonate, it is known as white alkali. Such a soil is not

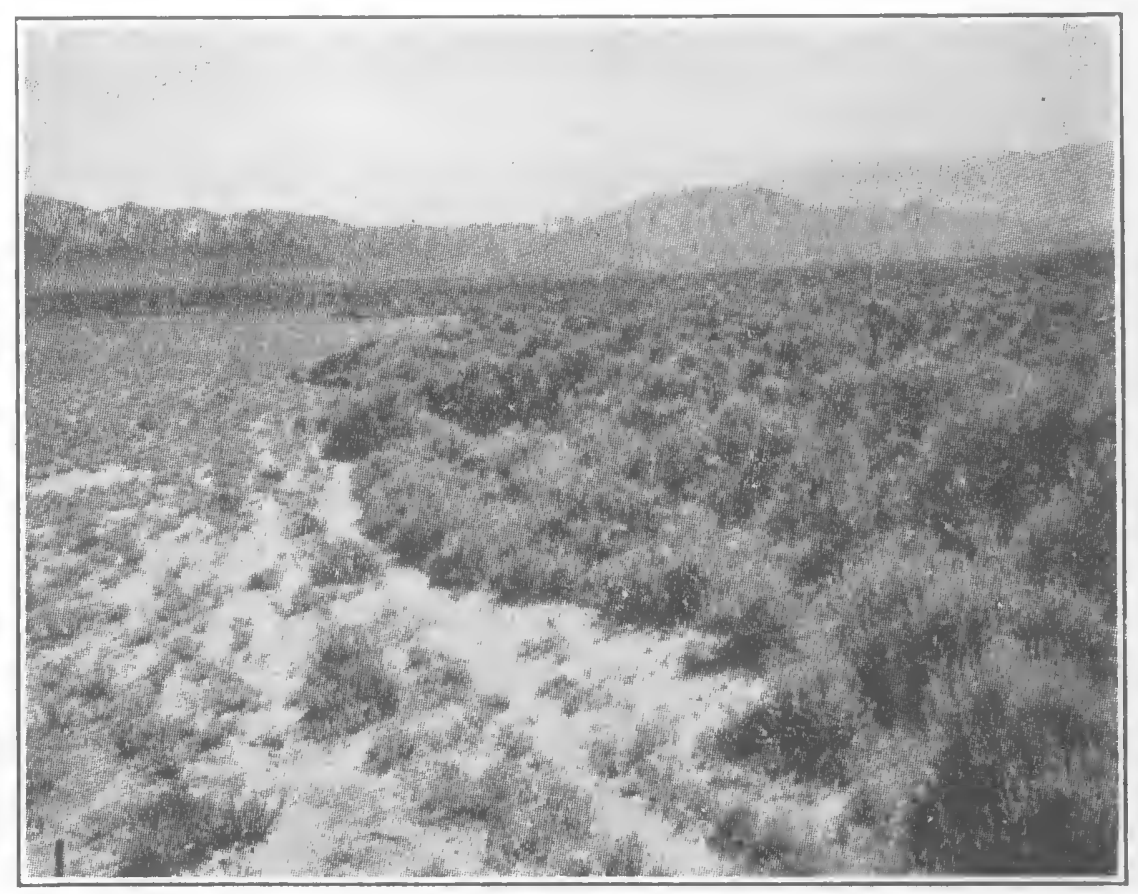

Frg. 39.-Vegetation on alkali and alkali free soil. (After Kearney et al.)

necessarily white but is nearly free from sodium carbonate. Where there is considerable sodium carbonate or sodium nitrate present we have what is known as black alkali. It is so-called from the dark color which these constituents impart to the soil when they react with its organic matter. Black alkali is very destructive to plants; it tends to puddle the soil, and the sodium carbonate clings very tenaciously to the soil particles, thus being very hard to wash out.

Kind and Number of Microörganisms in Alkali Soil.What a difference one observes in the native vegetation on look- 
ing from a fertile field to an alkali plot! The one is covered with a luxuriant growth of healthy vegetation and the other with a scant growth of salt grass or shadscale. Or, if the alkali becomes too concentrated, the land is a barren waste. A similar condition is found to exist on examining the microflora of the two soils. The fertile soil contains millions of microörganisms in every gram. There is an abundance of nitrifiers, ammonifiers, azofiers, cellulose ferments, and all the decay bacteria, whereas the molds are conspicuous by their absence. On examining the alkali soil we find the millions have dwindled into thousands, and in place of the rich variety of a fertile soil there are only a few of the more hardy species, and the molds often predominate.

Stimulation of Bacteria by Alkali.-Small quantities of most poisons when administered to man act as a stimulant, and it is only when the dose becomes larger that the poisonous action is perceptible. This appears to be a universal law, holding for man, animals, and plants including microbes, for it is found that when small quantities of alkali are added to a soil the bacterial numbers and activity increase. The extent of this increase varies with different microörganisms and also with the kind of alkali. If we consider the transformation going on in the untreated soil as 100 we then have the following for alkali-treated soils:

\begin{tabular}{|c|c|c|c|c|c|c|}
\hline \multirow[b]{2}{*}{ Salt } & \multicolumn{2}{|c|}{ Ammonification } & \multicolumn{2}{|c|}{ Nitrification } & \multicolumn{2}{|c|}{$\begin{array}{l}\text { Nitrogen } \\
\text { Fixation }\end{array}$} \\
\hline & $\begin{array}{l}\text { Lbs. per } \\
\text { Acre for } \\
\text { Highest } \\
\text { Stimula- } \\
\text { tion } \\
\end{array}$ & $\begin{array}{c}\text { Ammonia } \\
\text { Produced } \\
\%\end{array}$ & $\begin{array}{l}\text { Lbs. per } \\
\text { Acre for } \\
\text { Highest } \\
\text { Stimula- } \\
\text { tion }\end{array}$ & $\begin{array}{c}\text { Nitrates } \\
\text { Produced } \\
\%\end{array}$ & $\begin{array}{l}\text { Lbs.per } \\
\text { Acrefor } \\
\text { Highest } \\
\text { Stimu- } \\
\text { lation }\end{array}$ & $\begin{array}{c}N . \\
\text { Fixed } \\
\%\end{array}$ \\
\hline Sodium carbonate & 1,908 & IIO & \multicolumn{2}{|c|}{ No stimulation } & 1,908 & I IO \\
\hline Sodium nitrate & $1,76_{3}$ & 108 & $28 I$ & IOI & IgI & $\mathrm{IO}_{4}$ \\
\hline Calcium sulfate & 612 & $\mathrm{IO}_{4}$ & 9,800 & 197 & 4,900 & $\mathrm{IO}_{4}$ \\
\hline Magnesium sulfate & 270 & 105 & 137 & IOI & 68 & 104 \\
\hline Sodium chlorid & 66 & 106 & 2,000 & 143 & 526 & Iog \\
\hline Magnesium chlorıd & 28 & IOI & 850 & 123 & $x, 700$ & 103 \\
\hline No salt & $\circ$ & 100 & 0 & 100 & 0 & 100 \\
\hline Calcium chlorid & \multicolumn{2}{|c|}{ No stimulation } & 4,000 & I68 & $6 I$ & 102 \\
\hline Sodium sulfate & No stum & nulation & \multicolumn{2}{|c|}{ No stimulation } & $I, \infty 00$ & 108 \\
\hline
\end{tabular}


INFLUENCE OF SOIL, ALKALI ON BACTERIA I93

These results were obtained by adding the given quantity of the respective salt to a highly calcareous loam and then observing the concentration at which stimulation was greatest. This would differ probably with the texture and organic content of the soil.

Here we have a marked acceleration of the speed with which protein is transformed into ammonia when some alkalies are added to a soil. When $\mathrm{I}, 908$ pounds of sodium carbonate are added to this soil, ammonification is increased ro per cent. The other salts stimulate to a less but still an appreciable extent. This would give greater quantities of ammonia for the nitrifiers to work upon, and it is seen that they are stimulated to even a greater extent than are the ammonifiers.

All of the salts also increase nitrogen fixation; hence, the addition of some alkalies to a soil increases not only the available but also the total nitrogen supply of the soil. The increased bacterial activity would liberate more phosphorus and potassium for the plant. Calcium sulfate or gypsum is especially active in increasing nitrification, and hence increases proportionately the plants growing on that soil. The dealer in gypsum often takes advantage of this fact in advertising his materials by writing the word PLASTER with a heavy application of the material in large letters on a cultivated field in view of the public road. In the larger greener growth of grain crops or grasses the word PLASTER can be read by the passersby. In this way the farmers are induced to use gypsum or land plaster. This, however, is usually a stimulant, and if the landowner will continue to apply the material year after year where the word was first written, the time will come when it cannot be read. If he continues the application long enough ultimately one may again read the word PLASTER, but this time the grain composing the word would be inferior to that surrounding it. Moreover, where the plaster has been applied the physical properties of the soil would be found to be bad.

Common salt is also of ten used as a crop stimulant. This acts mainly by increasing bacterial activity and with the exception of the true gain in nitrogen it is also a stimulant. Now, it may be 
legitimate at times to use such substances, but the farmer should do so with the understanding that he is using a stimulant-not a plant-food-and that he is getting a temporary-not a permanent-effect.

Toxicity of Alkali Salts.-If we gradually increase the quantity of alkali salts in a soil there will come a time when the bacterial activities are decreased. The quantity of alkali which must be added to a soil to become poisonous to bacteria varies with the salt, the soil, and the bacteria. The quantity, stated as pounds per acre, which it was found necessary to apply to a calcareous loam in order to become toxic to ammonifying and nitrifying organisms, is given below:

\begin{tabular}{l|c|c}
\hline \multicolumn{1}{c|}{ Salt } & $\begin{array}{c}\text { Ammonifier } \\
\text { (Pounds per Acre) }\end{array}$ & $\begin{array}{c}\text { Nitrifier } \\
\text { (Pounds per Acre) }\end{array}$ \\
\hline Calcium sulfate & 24,500 & - \\
Sodium carbonate & 22,890 & 57 \\
Sodium sulfate & 2,556 & 79 \\
Magnesium sulfate & 2,200 & 270 \\
Magnesium chloride & 1,700 & 29 \\
Sodium nitrate & 1,530 & 47 \\
Sodium chloride & 263 & 313 \\
Calcium chloride & 61 & 37 \\
\hline
\end{tabular}

These results are not to be taken as indicating that neither ammonia nor nitrate is produced in a soil containing the above quantities of alkali, as these are the concentrations at which the activity of the microörganisms are slowed down.

Ammonia is produced in a soil containing considerable alkali, but the production of nitrates is interfered with even when small quantities of alkali are present. The great difference shown between ammonifiers and nitrifiers is due to the fact that many molds ammonify, whereas it is only bacteria which nitrify. Molds are considerably more resistant to alkali than are bacteria.

Much larger quantites of alkali than those reported above would have to be in a soil before the nitrogen-fixing bacteria are 


\section{INFLUENCE OF SOIL ALKALI ON BACTERIA 195}

injured. Hence, we find in an alkali soil that the nitrifying bacteria disappear first, followed by the ammonifying, and finally in the barren waste the nitrogen-fixing microörganisms disappear.

The first injury is due to increased osmotic pressure of the soil solution, as the osmotic pressure of all these solutions at the point at which they became injurious was between 1.65 and 1.95 atmospheres. However, as larger quantities of the salts accumulate they poison the soil microörganisms. This is highly fatal to the nitrifiers but less so to the ammonifiers, and still less to the nitrogen-fixing microörganisms.

It is interesting to note that alkali salts become poisonous to nitrifying microörganisms considerably before they do to higher plants. Therefore, it is quite possible that the early injurious effect observed when land starts to "go bad," from an accumulation of alkali, is due to the action of the salts on the nitrifiers, and only after it becomes more concentrated does it actually injure the plant. Moreover, after a soil has been leached of its alkali it is a number of years before it becomes productive. This unproductive condition is due in a measure to the bad physical condition of the soil. This is not the only factor, however, as the addition of manure or extracts of productive soil greatly shortens the unproductive period by bringing to the soil the necessary bacterial flora.

Variation in Toxicity.-The toxic or poisonous action of a salt varies not only with the kind and quantity of salt present but also with the soil. A quantity of common salt or other alkali which would be sufficient to greatly retard bacterial growth in a soil of coarse texture may be without effect in one of fine texture. Moreover, a salt is more poisonous in a soil low in organic content than in one of high. It would appear that the greater surface exposed to the action of the salt in the fine textured soil holds the salt in such a way that the bacteria are not injured. This is spoken of as absorption. Moreover, salts are less toxic where there is a mixture than where there is present a single salt.

Antagonism. - If certain salt-water fish be placed in a solution of common salt having the same osmotic pressure as has sea-water 
the fish soon dies. Death in this case is not due to a lack of food, as a similar fish placed in distilled water lives for some time. Now, if a small quantity of calcium chloride had been added to the first solution the fish would have lived normally. Moreover, if the heart be removed from the body of a cold-blooded animal and placed in a salt solution it soon dies, but if a small quantity of calcium salt be present the heart beats normally for some time. When one salt thus counteracts the poisonous effect of another it is spoken of as antagonism and a solution made up of a mixture of salts such that there is no toxic effect is known as a balanced solution.

This property of antagonism also exists with regards plants. One may take a soil which contains sufficient common salt to be injurious to plant life and overcome the toxicity by adding calcium salts to it. This appears to be a general law, as the injurious action of sodium carbonate, sodium sulfate, and a number of other salts toward bacteria can be neutralized by the use of calcium salts. The extent to which this neutralization can be carried is limited, as it is only the less concentrated salts which can be thus neutralized. However, this does indicate that a concentration of a single salt is of ten more injurious than is a similar concentration of several salts. We, therefore, have the peculiar phenomenon of being able to reclaim some alkali soils by adding more alkali to them.

Numerous workers have attempted to explain this peculiar phenomenon. Even before ideas on antagonism had taken a definite form, Loew elaborated a theory to account for the toxic properties of magnesium when calcium was not present in suffcient quantity. He supposed calcium to be a necessary constituent of the chlorophyll bodies and nucleus, and when magnesium is present in great excess this takes the place in those bodies which should be occupied by calcium. This caused a structural disturbance on account of which the protein substances cease to be active and death ensues. It will be observed that this will only explain the need for a balance between calcium and magnesium and not between other compounds, as is of ten the case. Osterhout 


\section{INFLUENCE OF SOIL ALKALI ON BACTERIA I97}

who has done much work in this field considers that the value of calcium lies in its effect at the surface between the absorbing membrane and the external solution and is not due to chemical action inside the cell. $\mathrm{He}$, therefore, explains antagonism by assuming that antagonistic substances prevent each other from entering the cell. For, according to Loeb, if the wrong salts reach the inside of the cell they replace the salts in the protein and the cell dies.

Out of this work has grown the idea of physiologically balanced solutions, or as Osterhout put it, "Normal life is possible only when necessary salts combine with the colloids of living substance in a definite ratio."

How to Overcome Poisonous Action.-The methods which have been used for eradicating the evils of alkali salts on plant and bacteria are of two classes. The first attempts to inhibit the toxic effects of the salts without removing them from the soil, and the second attempts to overcome the bad effect by the total removal of the salts from the affected soil.

Neutralizing Salt.-Where the injurious constituent is sodium carbonate and it is not present in too great a concentration it may be combatted by the use of gypsum. 'The gypsum changes the black alkali into the less toxic sodium sulfate. In addition to changing the salt into a less poisonous substance, this treatment greatly improves the tilth of the soil. Moreover, a preliminary treatment such as this is often necessary before black alkali can be leached from the soil.

Lipman has shown that the addition of large quantities, thirty to forty tons, of barnyard manure to a soil in which the concentration of alkali is not too high will of ten render the soil productive. This, he considers, to be due to the rapid decay of the organic substance with the formation of large quantities of colloidal material. This would greatly increase the actual surface on which the salts could be held away from the plants and bacteria. This being the case, as the manure decays the injurious action of the salt reappears.

Great hopes have been held out by some workers that the in- 
jurious action of alkalies in a soil may at times be neutralized by a balancing of the soil solution, that is, the addition of a second salt which would offset the effect of the one present in the soil. This is possible to a limited extent. For instance, calcium, magnesium, or even iron salts have been added to an alkali soil and their bacterial flora greatly improved. This method, however, is

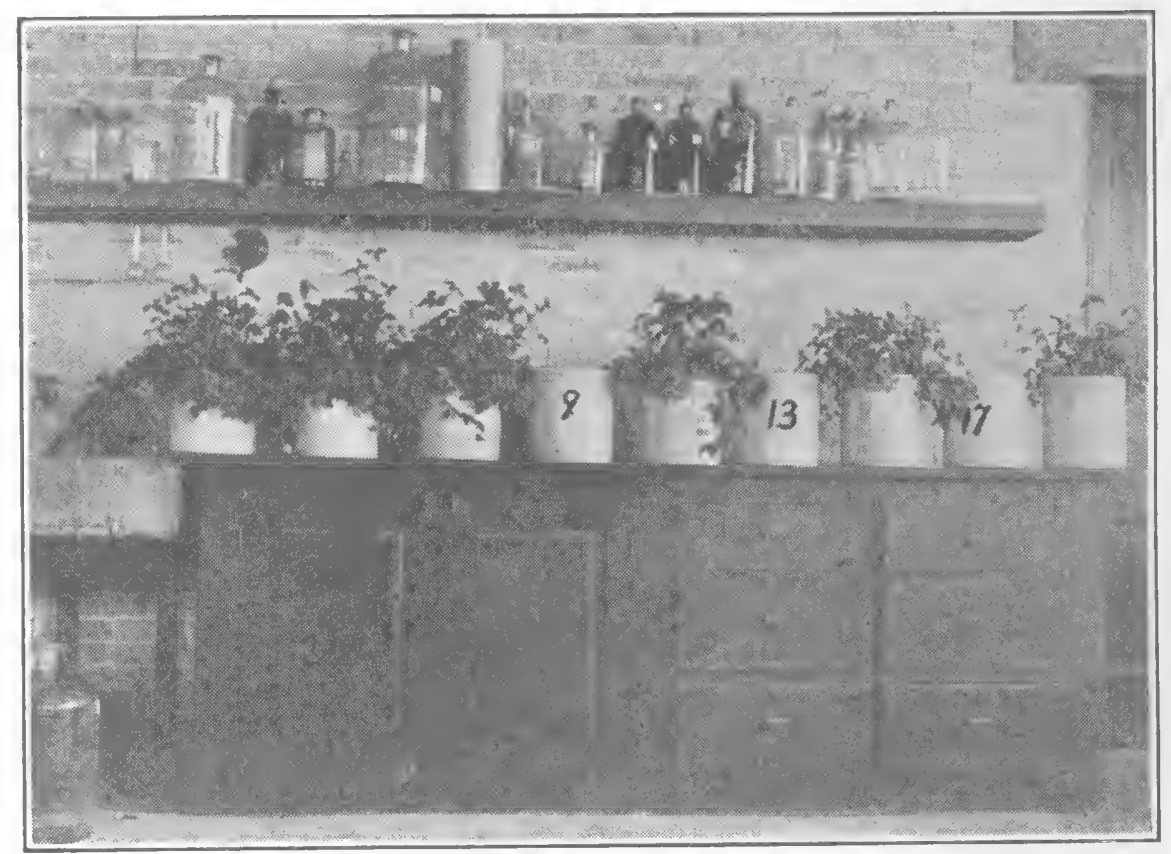

Fig. 40.- Influence of alkali on growth of crimson clover. Reading from left to right: (I) normal soil, (2) soil leached, (3) leached $+15 \mathrm{~T}$ manure, (4) soil with 2 per cent sodium chloride, (5) sodium chloride leached out, (6) soil with sodium chloride +15 tons manure, $(7)$ leached +15 tons manure, $(8)$ soil with sodium chloride + extract from fertile soil, (9) leached + extract of fertile soil.

in the experimental stage and too great reliance must not be placed upon it in actual practice.

Removing the Salt.-Several methods have been used with varying degrees of success for the removal of the salts from the soil:

(I) By the growing of alkali-resistant plants on the soil. These are harvested and removed. When the plants are pastured from the soil no benefit would result.

(2) In limited areas it has been found feasible to scrape up 
INFLUENCE OF SOIL ALKALI ON BACTERIA I99

much of the alkali when it accumulates at the surface during certain seasons of the year. The scrapings are then carted from the land.

(3) Some farmers attempt to flood the affected area and quickly drain off the water, hoping that in this way considerable of the surface alkali may be picked up by the water. However, such attempts usually meet with failure because the water which dissolves the alkali usually penetrates the soil and is not subsequently drawn off.

(4) The most successful method for reclaiming alkali soil is by the leaching out of the soluble constituents by means of water. In order that this be a success there must be a good underdrainage and the water applied in quantities sufficient to pass down through the soil and carry with it the alkali. This is the only permanent method, as it is the only one which completely removes the cause. Even where the alkalies are washed out it is of ten a number of years before the soil becomes productive. This is probably due to the absence of the requisite bacterial flora. Moreover, during the leaching out of the alkali much of the available plant-food would also be carried out. Hence, more must be rendered available by later bacterial activity. The period of unproductivity may be greatly shortened by the addition of large quantities of barnyard manure. 


\section{CHAPTER XIX \\ INFLUENCE OF HEAT AND POISONS ON SOIL BACTERIA}

Nature repairs the flesh wounds of man with scar tissue, the broken bones with new cartilage, and the injury to the nyster's shell with a pearl. The reparation in each case is in excess of that required. This appears to be a general law in the animal kingdom. Now, injure the bacterial flora of the soil, and what will happen? Do the remaining microbes dwindle and eke out a scant existence? Or does a greater and more powerful variety spring from the ruins?

Heat.-The early Romans understood that the heating of soil rendered it more productive, and this has been the experience of the practical farmer down through the ages. The place where a pile of weeds has been burned is perceptible from the deeper green of the plant growing thereon during the succeeding year. The dry-farmer in the arid regions knows that the burning of heavy stubble is followed by a better crop. It is self-evident that this gain cannot come from the few pounds of potassium or phosphorus which is contained in the ashes, for of ten most of these are carried from the soil by winds.

The work of the modern chemist has shown that the heating of a soil increases its soluble plant-food. Possibly some of the organic compounds are burned and the phosphorus and potassium liberated. It may be that the heating of the nitrogen compounds renders them more vulnerable to the attacks of the microbes. It was thought until the dawn of the twentieth century that these changes were sufficient to account for the observed effect upon the crop, but the recent researches of the biologist have shown that the partial sterilization of soil by heating to a temperature of $60^{\circ} \mathrm{C}$. or more caused at first a decided decrease in the number of microörganisms which it contains. This is followed by a 
rapid increase which may persist for even 200 days or longer. There is a tendency for ammonia to accumulate, thus showing that it is either being produced more rapidly than it was before the soil was heated or that something has happened so that the ammonia is not as rapidly transformed into nitrates. After a time the soil regains its power to produce nitrates, after which they are produced in greater quantities than they were before the soil was heated.

The heating of a soil greatly accelerates the oxidation going on within it, as may be seen from the following results reported by Darbishire and Russell:

\begin{tabular}{l|l|c|c|c}
\hline \hline \multirow{2}{*}{ Kind of Soil } & \multirow{2}{*}{ Treatment } & \multicolumn{3}{|c}{ Mgm. of Oxygen Absorbed in } \\
\cline { 3 - 5 } & & 3 Days & 6 Days & 9 Days \\
\hline Hop garden soil & untreated & 3.7 & 5.2 & 7.0 \\
Hop garden soil & heated to 95 C. & 6.0 & 8.2 & 12.0 \\
Garden soil & untreated & 7.5 & 10.2 & 15.5 \\
Garden soil & heated to 95 C. & 10.9 & 27.2 & 33.2 \\
& & & & \\
\hline
\end{tabular}

There is also an increase in the nitrogen-fixing powers of the soil, as may be seen from the following results. They were obtained with a soil which had been heated long enough to destroy all life and then treated with extracts from a fertile soil. This had been heated to varying temperatures.

\begin{tabular}{c|c}
\hline \hline $\begin{array}{c}\text { Temperature to Which Soil Extract } \\
\text { Was Heated }\left({ }^{\circ} \mathrm{C} .\right)\end{array}$ & Mgm. of Nitrogen Fixed \\
\hline Not heated & $5.1 \mathrm{I}$ \\
50 & 9.00 \\
55 & I4.14 \\
60 & 16.38 \\
65 & 14.42 \\
70 & 13.02 \\
75 & 1.35 \\
80 & 12.66 \\
85 & 10.36 \\
\hline
\end{tabular}


The gain of nitrogen in this soil was at its maximum when the soil extract had been heated to $60^{\circ} \mathrm{C}$. Above or below this temperature there was a decrease in the fixation of nitrogen.

Some workers have found that heat decreases the denitrifying organisms of the soil. Moreover, most workers have found that heating of a soil causes a disappearance of the microfauna, especially the protozoa.

Other workers claim that the heating of the soil removes from it certain poisonous substances which have accumulated from the growth of specific plants, which, if permitted to remain in the soil, interfere with plant growth. It is quite evident from the preceding brief summary that the heating of soil changes profoundly both its chemical and biological composition.

Antiseptics.-Carbon bisulfid and other volatile antiseptics are often applied to plants, and indirectly they find their way into soil or else are added directly to the soil for the purpose of killing parasites. Carbon bisulfid was first used by Oberlin, an Alsatian vinegrower, to free his vineyard of phylloxera and later by Gerard to clear a piece of sugar-beet land badly infected with nematode. Both observers found that subsequent crops were bigger and better. From this observation Oberlin founded his system of grape culture in which carbon bisulfid was used to replace fallowing and rotation in the resetting of vineyards. Since that time many workers have observed that carbon bisulfid, toluene, ether, and other volatile antiseptics greatly increase the productivity of the soil.

Koch found that the use of carbon bisulfid at the rate of 2904 pounds an acre resulted in a gain of 15 to 46 per cent in the yield of wheat grain and from 21 to 80 per cent in the yield of straw. The yield of potatoes was similarly increased by 5 to $3^{8}$ per cent and that of beets from 18 to 29 per cent. Although the yields of the legumes were not always increased, yet some fields of clover gave increases of IIg per cent. The influence is perceptible according to the amount of carbon bisulfid used throughout one or several growing seasons, after which if no manure or fertilizer is applied a marked decrease in the yields becomes evident. 
There is the dark green color and the vigorous development of the plants together with the decided tendency of grain crops to lodge just as if too great quantities of nitrogen were at their disposal. These facts led Heinze to conclude that on the whole we must seek the cause of the beneficial effect of carbon bisulfid on the soil in the enormous increase of soil microörganisms at the proper time, thus rendering available, or possibly increasing, the nitrogen supply to growing plants.

The large amounts of nitrogen thus made available to the crops are derived partly from soil sources and partly from atmospheric sources. Kruger and Heinze not only demonstrated that soils treated with carbon bisulfid showed an increase in their total nitrogen content but also that the increase was the result of the more vigorous growth of the nitrogen-fixing Azotobacter species. This, Heinze considers, resulted from the initial suppression of amid-ammonia formation and nitrification which would create favorable conditions for the development of the nitrogen-fixing flora. Later there would be more intense transformation of the bacterial proteins and of other nitrogenous organic substances into amino- and ammonia compounds which would result in a more vigorous nitrification, thus placing at the disposal of the plant an abundant and uniform supply of soluble nitrogen compounds. The various organic materials in the soil, such as plant residues, pectins, pentosans, humic substances and the like, together with the rapid growth of algae and molds, may furnish the carbon food for the Azotobacter species. In short, we have a cycle of changes similar to those outlined as occurring in a heated soil.

How Account for These Conditions?-Numerous theories have been advanced to account for the observed phenomena. However, only two of the more likely and interesting ones can be considered here.

Hiltner and Stormer explain the changes as follows:

"(I) By destroying the existing bacterial equilibrium in the soil the carbon bisulfid opens the way for an entirely new bacterial development. This is achieved through the unequal retardation in the growth of the different groups of bacteria. Hence, certain 
groups become disproportionately prominent, while others are almost entirely suppressed.

"(2) The rapid increase in the numbers of the bacteria is followed by a more intense transformation of plant-food substances. Decomposition and fixation processes result in an accumulation of readily available nitrogen compounds utilized by the crops. Hence, the action of carbon bisulfid is in the nature of nitrogen action.

"(3) The initial suppression of the nitrifying species becomes of advantage in that the nitrogen compounds, simplified by other species are prevented from being rapidly changed into nitrates and being leached out of the soil.

"(4) The more or less permanent suppression of the denitrifying organisms must be regarded as an additional factor favoring plant growth.

"The introduction of the poison into the soil at first decimates its bacterial flora, but with the disappearance of the injurious carbon bisulfid vapors it also encourages a vigorous and long-continued increase of the organisms, resulting in an increase of the store of more readily available nitrogen. It is still to be determined whether this increase is largely due to the fixation of atmospheric nitrogen or to the unlocking of the vast store of combined nitrogen in the soil. It is most probable, however, that even though one of these processes predominates the other is surely more extensive than it would be in normal soil. The nitrogen thus secured is not at once made accessible to the higher plants but is at first laid fast in the bacterial bodies. This assumption would best explain the fact that plants growing upon a soil treated with carbon bisulfid show retarded growth, even some time after the application of the latter, and the explanation hitherto accepted that the injury results from the direct action of the poison seems hardly reasonable after our discovery that the most intense bacterial activities are asserting themselves just at this time. The nitrogen fixed in the bacterial bodies is gradually rendered soluble by decomposition processes, and thereby made accessible to nitrification and the higher plants. Hence, when the carbon bisulfid is 
applied in the fall there is enough time left until the planting of the following spring crop for the mineralization of the bacterial nitrogen. It is quite evident, of course, that the nitrogen combined in the bodies of generations of bacteria is not all made soluble within a single year, but only in the course of several growing seasons, so that we may readily account for the increased harvests secured for two or more successive years after strong applications of carbon bisulfid, even though the bacterial transformations had by that time declined. The exhaustion of the soil finally manifesting itself after a shorter or longer time may be explained by the deep-seated changes in the bacterial soil flora, which does not return so easily to its normal state. It is quite possible that the return to the normal conditions is prevented by the exhaustion for years to come of the more available portions of the plant nutrients."

The theory of Russell and Hutchinson is both interesting and probable. They maintain that within the soil are microscopic plants, bacteria, and also microscopic animals, protozoa. The protozoa are many times larger than the bacteria, and when examined under the microscope they are seen moving about and creating, viewed from the standpoint of the bacteria, great waves. They can be seen continually feeding upon the minute bacteria. This would keep down the number of bacteria in the soil. Now, when a weak antiseptic is applied to the soil it kills many of the protozoa as they are more sensitive to poisons than are the bacteria. The bacteria, being no longer preyed upon by their natural foe, rapidly multiply. The ammonifiers are not injured to as great an extent as the nitrifiers, the result being that ammonia at first accumulates. But later the nitrifiers rapidly multiply as there are no protozoa to feed upon them; hence, we have a rapid production of nitrates. As the antiseptic evaporates the few remaining protozoa multiply and soon are able to keep the bacteria in check. Hence, the struggle for existence goes on in the soil; one species preys upon the other. It is possible that microscopic life wage battles within the soil proportionately as terrific as those waged by the higher animals upon the earth's surface. 
Metallic Poisons.-Copper, lead, and arsenic at times occur naturally in native agricultural soil and at times are added to soils by sprays and from smelter smokes. Hence, the question naturally arises as to what influence they are going to have upon the microflora of the soil. Moreover, it is of economic impor-

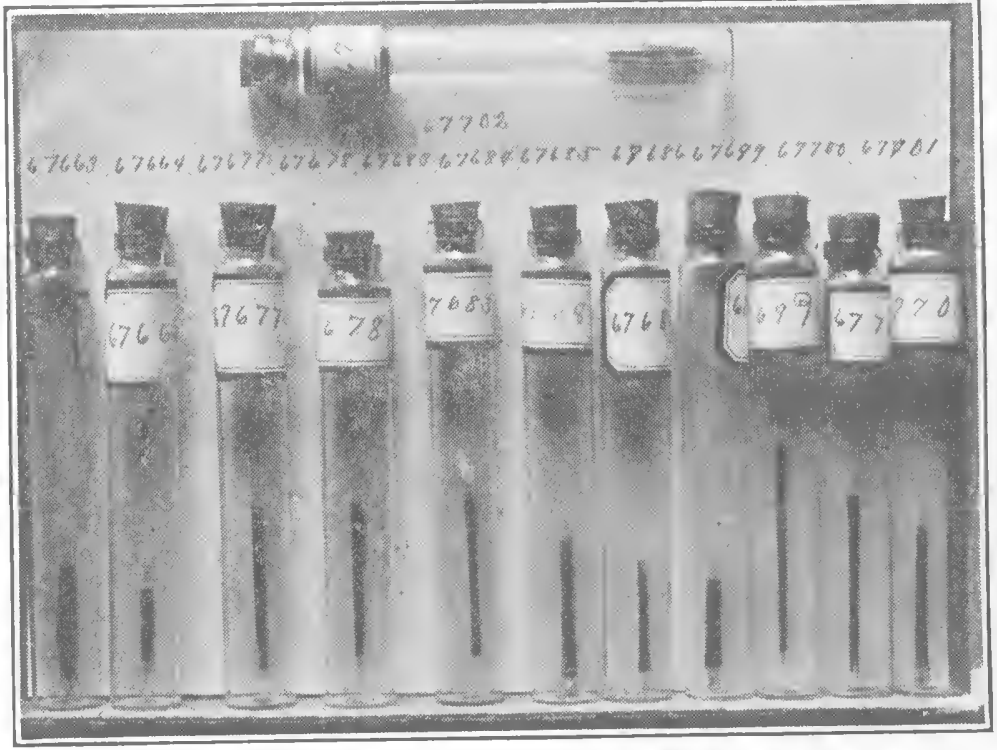

FIG. 41.--Arsenic obtained from various soils. tance as any factor which modifies the bacterial flora must of necessity influence the crop.

Extensive studies have been made on the influence of various a rse $\mathrm{n}$ i c compounds u p o $\mathrm{n}$ the bacterial flora of the soil with the result that arsenic was found to be a stimulant in low concentration and toxic only in larger quantities. The extent of stimulation and toxicity varies greatly with the specific type of microörganism and the form in which the arsenic is applied.

Ammonifiers.-Experiments on ammonifiers demonstrated that this class of bacteria are not at first injured by the arsenic, but their speed of action is increased. The actual results showed that whereas the untreated soil produced in unit time $\mathbf{I} 00$ parts of ammonia, soil to which sixty pounds of arsenic in the form of lead arsenate an acre was applied produced 103 parts of ammonia in the same length of time. And it was not until 2,500 pounds of arsenic an acre was applied to the soil that the production of ammonia was reduced to one-half normal. The Paris green, on the other hand, retarded the action of this class of bacteria even in the lowest concentration added, and by the time 600 pounds an acre had been applied the ammonia produced in unit time had been reduced to one-half normal. The poisonous action 
of arsenic on bacteria is in a direct relationship to its solubility. An extremely large quantity of lead arsenate would have to be applied to a soil before it would interfere with ammonification.

Nitrification.-The nitrifying flora of a soil are stimulated to a greater extent by small quantities of arsenic and are more resistant to larger quantities of arsenic than are the ammonifiers. Tests made in soil showed that whereas untreated soil produced roo parts of nitrates in unit time, the same soil to which had been added arsenic in the form of lead arsenate at the rate of 120 pounds an acre produced 178 parts of nitrates. In other words, in place of being injured by the arsenic the bacteria were nearly twice as active in the presence of this quantity of arsenic as they were in its total absence. It was not until more than 700 pounds of arsenic per acre, in the form of lead arsenate, had been applied to the soil that the bacterial activity sank back to roo. Even when arsenic in the form of lead arsenate was applied at the rate of 3,500 pounds an acre there was 68 per cent as much ammonia produced as in the untreated soil. The Paris green gave similar results. The untreated soil produced Ioo part of nitrates in given time whereas similar soil to which arsenic in the form of Paris green was added produced, under the same condition, I 29 parts of nitrates. When higher concentrations of arsenic in the form of Paris green, however, were added it became toxic, and eventually stopped all bacterial activity. The quantity added had to be so large that it is not likely that sufficient would ever occur under agriculural practice.

Arsenic, then, does not injure the ammonifying or nitrifying organisms of the soil. But how about the other beneficial bacteria of the soil? What effect has it upon them?

Nitrogen Fixation.- - How does arsenic influence the nitrogen fixers? Are they also stimulated or injured by it? The answer to these questions came when arsenic in the form of lead arsenate, zinc arsenite, and arsenic trisulfid were added to the soil and their influence noted. When arsenic in the form of lead arsenate was applied to the soil at the rate of 500 pounds an acre, the azofiers gathered twice as much nitrogen in unit 
time as they did in the absence of arsenic. The Paris green, however, is poisonous to this group of organisms in the minutest quantities. This is due to the copper and not to the arsenic found in the compounds.

How Does the Arsenic Act?-We may, therefore, conclude that arsenic stimulates all the beneficial bacteria. But how does it act? Will it stimulate for a short time and then allow the microörganism to drop back to its original or to a lower level as does alcohol and various other stimulants when given to

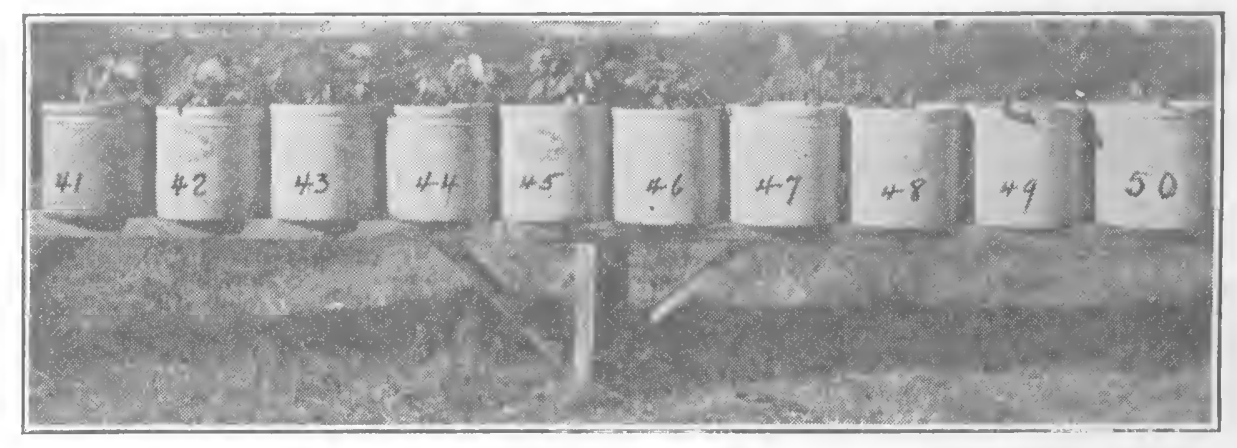

FIG. 42.-Beans grown on arsenic treated soil. No. 4 I received no arsenic the others small increasing quantities. Note the greater growth in 45 and 46 due to the arsenic. (After Stewart.)

man? Or will it act as does caffeine-continue to stimulate? From the results on men and horses the former might be expected, for although the arsenic eaters of India and Hungary maintain that the eating of arsenic increases their endurance-and there is considerable evidence to indicate this-it is only for a short time. If the use be not continued the arsenic eaters cannot endure as much physical exertion as can others who are not addicted to the drug. Many European horse dealers place small quantities of arsenic in the daily corn of the horse for they find it improves its coat. If a horse, however, has been doped on arsenic for any length of time it seems necessary to continue the practice; otherwise, the animal rapidly loses his condition.

Similar results might be expected with the bacteria, and experiments have shown that although during the first few weeks the bacterial activity of soils containing small quantities of ar- 
senic is much greater than it is in a similar soil without arsenic, this activity continues to grow less and less, until at the end of several weeks it is no greater than in soil containing no arsenic.

It may be that part of the stimulation can be accounted for by the protozoan theories of Russell and Hutchinson. We would have to assume that arsenic acts more readily upon the protozoa than upon the bacteria. After the arsenic has been in the soil for some time it may become insoluble or some of it may be changed by molds into a gas arsine and pass into the air. Then the few protozoa which have not been destroyed by its presence may rapidly multiply and soon hold the bacteria in check.

This, however, is not the only way in which arsenic acts, for pure cultures of the Azotobacter have been obtained from these soils, and it is found that they also are stimulated. This is due to the action of the arsenic upon these minute specks of living protoplasm, causing them to utilize their food more economically in the presence of arsenic than in its absence. Hence, this is similar to the influence of the arsenic upon the cells of the horse.

Other experiments have demonstrated that the addition of arsenic to a soil increases the quantity of soluble plant-foods in the soil, especially the phosphorus. Thus arsenic by various means stimulates all the bacterial activities of the soil, and these increased activities, as experiments have shown, are reflected in greater crops grown upon that soll. This increased growth must be looked upon as being due to a stimulant and not to the direct nutritive value of the substance added. Soils so treated would produce larger crops and wear out more quickly than would untreated soils. It is interesting and important to know that arsenic has to be applied to a soil in enormous quantities before it retards microscopic plant life, and probably before it retards the growth of higher plants. 


\section{CHAPTER XX}

\section{MANURE}

The most important by-product of the farm in so far as soil fertility is concerned is manure. Yet there is no other product which is wasted to a greater extent. The waste is usually greater in new than in old districts, due chiefly to the belief of the farmer in new districts that manure is unnecessary for his soil because his virgin soil is producing good crops without it. Moreover, many farmers do not understand the value of farm manure and its great loss if not properly handled.

Composition.-There are a number of factors which determine the value of manure:

I. The composition of a manure is dependent upon the feed and the bedding received by the cattle. The average composition of some common feeds is given below:

\begin{tabular}{l|c|c|c}
\hline \multirow{2}{*}{ Feed } & \multicolumn{3}{|c}{ Pounds in I Ton of Produce } \\
\cline { 2 - 3 } & Nitrogen & Phosphorus & Potassium \\
\hline Alfalfa hay & 50 & $4 \cdot 5$ & 24 \\
Timothy hay & 24 & 3 & 24 \\
Wheat straw & I0 & 2 & 2 \\
Wheat & 48 & 8 & 9 \\
Corn & 33 & 6 & 7 \\
\hline
\end{tabular}

The quantity of the various constituents which are retained by an animal varies with the age and species. However, taking into account of the different animals found on the average farm it is conservative to assume that 50 per cent of the dry matter and 80 per cent of the total nitrogen, phosphorus, and potassium occur in the solid and liquid excreta. Now, it is evident from these 
results that manure produced from alfalfa hay, grain, and corn are more valuable than similar manure produced from straw and timothy hay. For ordinary purposes it is sufficiently accurate to use the figures given by Hopkins as $10,2,8$ as representing approximately the average pounds of the three elements-nitrogen, phosphorus, and potassium-in a ton of average fresh manure.

2. The value of manure varies greatly with the water content. Sheep and horse manure contain about half as much water as do hog and cow manure, and fresh manure more than old manure.

\begin{tabular}{|c|c|c|c|c|c|}
\hline \multirow{2}{*}{ Authority } & \multirow{2}{*}{$\begin{array}{l}\text { Kind of } \\
\text { Manure }\end{array}$} & \multicolumn{4}{|c|}{ Pounds per Ton } \\
\hline & & Dry Matter & Nitrogen & Phosphorus & Potassium \\
\hline $\begin{array}{l}\text { Wolf } \\
\text { Cornell Exp. Sta. }\end{array}$ & $\begin{array}{l}\text { Cow } \\
\text { Horse } \\
\text { Sheep } \\
\text { Average Yard } \\
\text { Manure }\end{array}$ & $\begin{array}{l}450 \\
659 \\
720 \\
502\end{array}$ & $\begin{array}{r}6.8 \\
\text { II. } \\
\text { I } 6.3 \\
\\
\text { I0.4 }\end{array}$ & $\begin{array}{l}\mathrm{I} .4 \\
2.4 \\
2.1 \\
\\
2.9\end{array}$ & $\begin{array}{r}6.6 \\
9.6 \\
\text { Ir.I } \\
\\
8.3\end{array}$ \\
\hline
\end{tabular}

Work in Colorado has shown that farmyard manure in a semiarid district contains as an average 13 per cent less moisture than similar manure in humid districts. A ton of manure containing 80 per cent of water contains only one-half as much plant-food as does a similar manure containing 60 per cent of water.

3. The composition of manure varies with the kind of animal producing it. Sheep and horse manure contains more plant-food than does cow and hog manure. Moreover, cow and hog manure is a cold manure and slowly decomposes either in the soil or in the pit. Manure from young-growing animals is less valuable than manure from mature animals.

4. The composition of manure varies with age and the losses which it has sustained during decomposition. Manure exposed to the weather will lose considerable of its potassium as well as its nitrogen. Hopkins gives the results of seventy-nine analyses of various farm manures made from different kinds of feed and 
bedding, containing varying amounts of water, and in different conditions of preservation or exposure, as nitrogen ranging from 4.2 to 27.2 pounds per ton, phosphorus from .9 to 6.5 pounds, and potassium from 2.2 to 23.2 pounds per ton.

Losses from Manure.-The losses sustained in manure vary with the following factors:

I. Time and condition when conveyed to the field. Manure which is produced on the field suffers smaller losses than does that manure produced in the stable and then conveyed to the field. This in turn shows less loss than manure allowed to accumulate in the barn and later carried to the soil. The loss is still greater where the manure is taken from the stable into piles. The use of an abundant supply of bedding material reduces the loss, as considerable of the liquid manure is thus saved.

2. The age of the manure greatly influences its composition, as anyone who has observed a pile of manure in a barnyard knows that it gradually diminishes in size and changes in appearance until it is finally difficult to distinguish it from the soil. The loss during this transformation is greater in the humid than in the arid districts. The average percentage loss of sheep manure kept in piles for the semi-arid region as reported by Headden is as follows:

\begin{tabular}{|c|c|c|c|c|}
\hline Time & $\begin{array}{c}\text { Dry } \\
\text { Weight }\end{array}$ & $\begin{array}{c}\text { Total } \\
\text { Nitrogen }\end{array}$ & $\begin{array}{c}\text { Total } \\
\text { Phosphorus }\end{array}$ & $\begin{array}{c}\text { Total } \\
\text { Potassium }\end{array}$ \\
\hline $\begin{array}{l}15 \text { months } \\
2 \text { years }\end{array}$ & $\begin{array}{l}32.5 \\
56.7\end{array}$ & $\begin{array}{l}48.6 \\
68.0\end{array}$ & $\begin{array}{l}42.0 \\
59.0\end{array}$ & 35.0 \\
\hline
\end{tabular}

That is, during one year the total dry weight decreases onethird and the total nitrogen and phosphorus about one-half. By the end of the second year nearly three-fifths of the dry matter, total nitrogen and phosphorus have been lost and one third of the potassium. Although old manure is richer in the essential elements of plant-food, pound for pound, than is fresh manure, 
yet considerable quantities of nitrogen, phosphorus, and potassium are lost in shrinkage.

3. The loss varies widely in stored manures, depending upon the conditions of storage. Light, porous, dry piles burn out much faster than do compact, wet piles. This is due to the rapid oxidation which goes on in the well-aerated piles. This at times is sufficient to burn out most of the organic matter and leave the remainder as a black charred mass. Manure piles subjected to the leaching of rain lose in plant-food faster than non-exposed piles. For this reason the loss in the humid districts is greater than in the arid. On the other hand, probably manure in the arid regions burns out faster than similar manure in the humid regions.

Value.-The value of barnyard manure varies with the composition of the manure, and the soil on which it is to be used, and the kinds of crops to be grown. The valuable constituents within it are the phosphorus, potassium, and nitrogen which are probably worth about the same as similar quantities in the form of commercial fertilizers. In addition to this, however, manure contains, organic matter which influences the physical properties of the soil and also furnishes food for bacteria. These in turn render available more plant-food from the soil to fix nitrogen from the atmosphere. The benefit derived in this latter case will vary with the composition of the soil. A soil containing considerable insoluble plant-food will respond better to small quantities of manure than will another soil containing small quantities of insoluble plant-food.

The results of the Pennsylvania Station indicate that in a good rotation the average value of manure was $\$ 1.65$ per ton where twelve tons per acre are used, $\$ 1.32$ where sixteen tons are applied, and \$I.I4 where twenty tons were applied for each four years' rotation. This would correspond to an annual application of 3,4 and 5 tons, respectively.

The work at the Rothamsted Station, which extended over a period of half a century, clearly demonstrates that fourteen tons per acre of farmyard manure will maintain the productivity of 
the soil better than will equivalent quantities of commercial fertilizers. This is true in the case of continuous wheat, barley, potatoes, mangels, and sugar-beets.

The value of the manure produced in the United States can be seen from the following:

"According to recent statistics there are in the United States in round numbers 19,500,000 horses, mules, etc., 6I,000,000 cat-

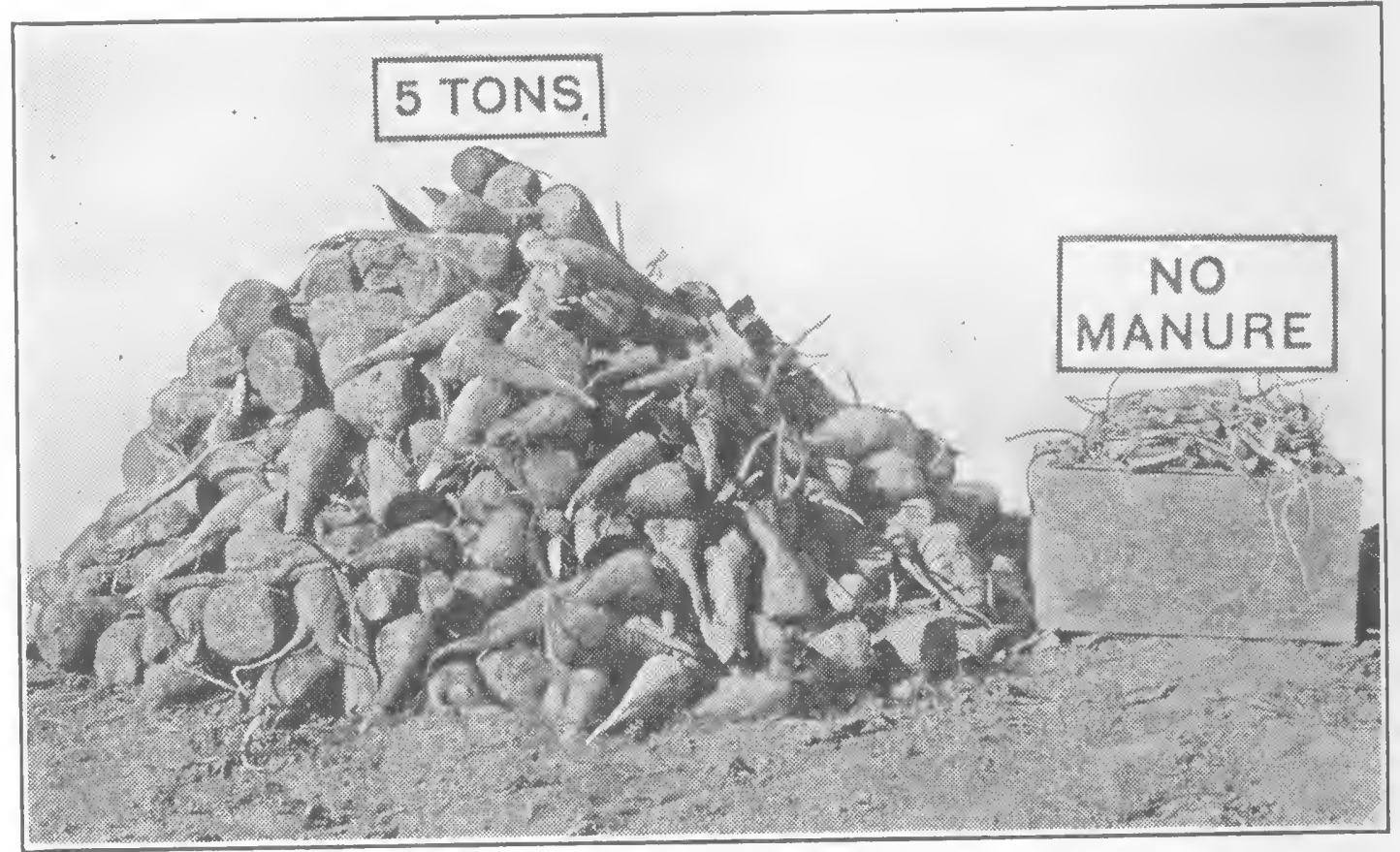

Fig. 43.-Beets grown on manured and unmanured soil. (Photo by Pittman.)

tle, 47,000,000 hogs and 51,600,000 sheep. Experiments indicate that if these animals were kept in stalls or pens throughout the year and the manure carefully saved, the approximate value of the fertilizing constituents of the manure produced by each horse or mule annually would be $\$ 27$, by each head of cattle $\$ 20$, by each hog $\$ 8$, and by each sheep $\$ 2$. The fertilizing value of manure produced by the different classes of farm animals of the United States would, therefore, be for horses, mules, etc., $\$ 526,500$, 000; cattle, \$1,220,000,000; hogs, \$376,000,000; and sheep, $\$ 103,200,000$ - or a total of $\$ 2,225,700,000$.

"It is conservative to state that fully one-third of the manure 
produced annually in the United States is wasted annually. This would mean a loss of soil fertility valued at $\$ 750,900$,000."

Influence on Number of Bacteria in Soil.-The biological changes which a manure produces in the soil, especially when small applications are made, may be more far-reaching than either the chemical or physical changes which it produces. Every pound of manure carries with it to the soil millions of bacteria. Many of these will find the new conditions unsuited to their growth, but some will continue to function, and in so doing not only will they decompose the manure but also alter other substances of the soil.

There are added with the manure many new species. The change in the soil from the addition of the manure will greatly modify those already present. The influence of manure on the number of bacteria in the soil is even greater than crop, temperature, or cultivation. If we consider the number of bacteria in unmanured land as 100 per cent, the Senior author obtained the following results for manured land:

\begin{tabular}{l|c|c}
\hline & Fallow & Cropped \\
\hline No manure & I00 & 100 \\
5 tons manure & I44 & I23 \\
I5 tons manure & I77 & 129 \\
\hline
\end{tabular}

Other workers have obtained even greater increases. The greatest increase is noted in fallow and per ton of manure for small applications. It is quite likely that the greater profit per ton of manure obtained with small over large applications of manure is due to increased bacterial activity.

Ammonification.-The nitrogen of solid excreta is mainly in the form of complex proteins; that of urine is in the form of urea, hippuric acid, and uric acid. Hence, when manure is added to a soil these compounds are carried into the soil and they furnish food for the millions of bacteria already present. Moreover, the manure contains varieties of organisms which act 
on each of these compounds. Hence, the addition of manure to a soil from a bacteriological viewpoint accomplishes two things. First, it furnishes food for the native bacterial flora, and second, it brings to the soil a richer and mightier flora. At times when only small quantities of manure are applied this second function may be even more important than the first. Some recent work indicates that small applications of manure for inoculating soil are even more efficient than the use of the pure cultures. This is especially true with regard to the use of manure on alkali soil that has just been leached of its salts. It also plays a very important rôle when added to a soil into which is being plowed green manures. It cannot, however, be depended upon as an inoculating medium for legumes, as it is quite evident that the manure can contain only those organisms which are in the alimentary tract of the animal and was on the food. Hence, if legumes are fed which had grown on inoculated soil the manure would contain a goodly seeding of the legume organisms. That the manure does greatly increase the rate with which the nitrogen of the soil is ammonified is seen from the following:

\begin{tabular}{c|c|c|c}
\hline & \multicolumn{3}{|c}{ Per Cent of Ammonia } \\
\cline { 2 - 4 } & Pots Fallow & Field Fallow & Field Cropped \\
\hline No manure & 100 & 100 & 100 \\
5 tons manure & $\mathrm{I} 22$ & $\mathrm{I} 47$ & 129 \\
15 tons manure & $\mathrm{I} 52$ & $\mathrm{I} 88$ & 183 \\
\hline
\end{tabular}

The unmanured soil was considered as producing Ioo per cent ammonia. Here the increase is nearly proportional to the quantity of manure used, but it is usually found to be the case that small applications are considerably more effective, ton for ton, than are large applications. Moreover, the increase in the fallow soil due to the greater aeration is greater than in the cropped soil.

Nitrification.-Although fresh farmyard manure does not nitrify in the pile, yet when applied to a soil the increase in am- 
monia leads to an increased production of nitrates. This process is accelerated proportionately to a greater extent than is ammonification, as may be seen from Fig. 44.

Moreover, there is a much closer correlation between increased nitrification and increased crop yield due to the use of farmyard manure than there is between increased ammonification and increased yield. This is what one would expect when it is recalled that it is the nitrates and not the ammonia upon which plants feed.

Green Manure.- Farm manure can be obtained only in conjunction with livestock farming, whereas green manure can be produced and used on all farms. In its use there are several principles which must be borne in mind.

I. Legumes feed first on the combined nitrogen of the soil and only turn to the atmosphere when the soil supply is insufficient.

2. Legumes can feed on atmospheric nitrogen only when properly inoculated.

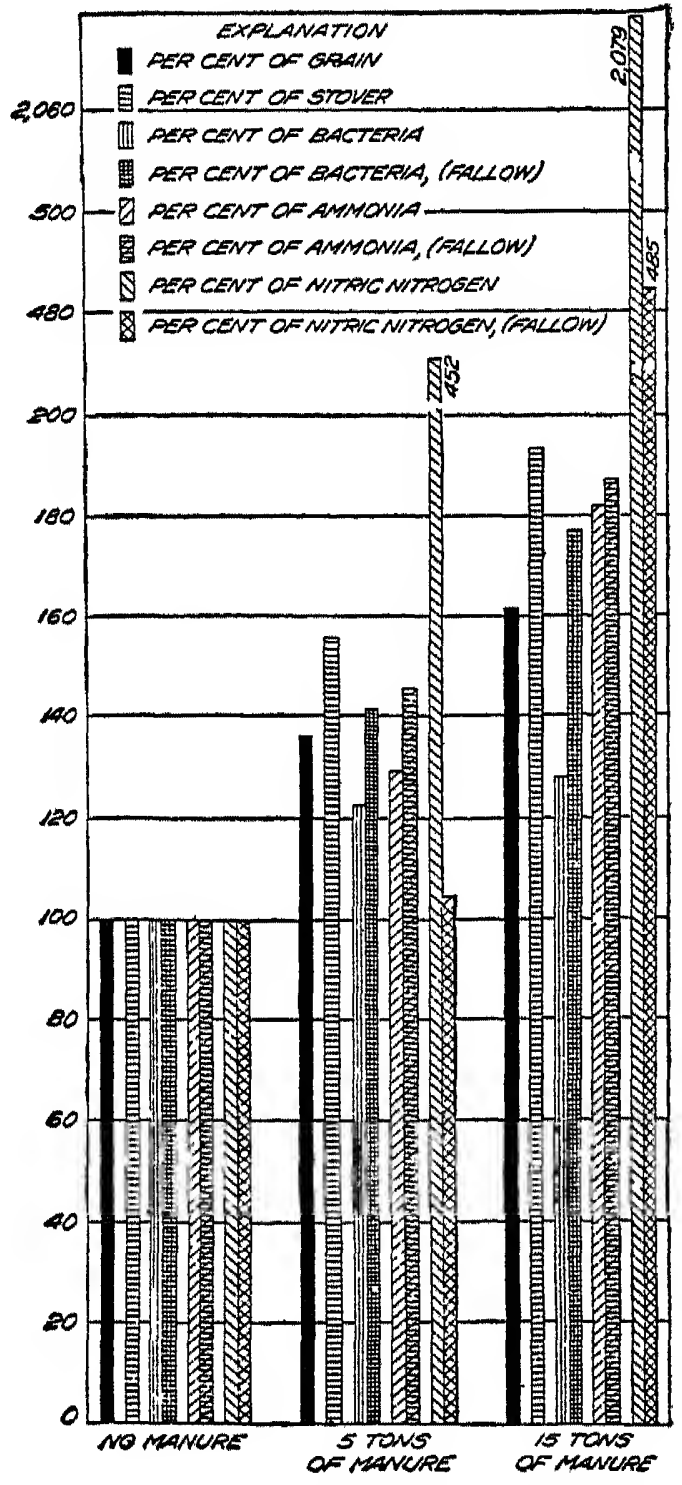

FIG. 44.-Illustrating the influence of manure on yeld of corn and bacterial activities of the soll.

3. One ton of alfalfa hay carries fifty pounds of nitrogen, whereas one ton of clover or pea hay carries approximately forty pounds of nitrogen.

In addition to carrying to the soil the above named quantities of nitrogen, green manures also carry large quantities of organic matter which furnish food for the soil microflora, and during the 
process of decay yield humus which greatly modifies the physical properties of the soil. Hence, the bacterial flora is both modified and increased. In addition to this, the plowing-under of the hay from inoculated legumes increase the total nitrogen supply of the soil. 


\section{CHAPTER XXI}

\section{THE INFLUENCE OF IRRIGATION WATER ON SOIL FERTILITY}

Irrigation water is applied to a soil primarily to meet the needs of the growing plant. Incidentally, it materially modifies the chemical, physical, and biological properties of the soil. (I) Water may increase or decrease the available plant-food in the soil without changing the total quantity; (2) water may carry from the soil plant-food, thus leaving it intrinsically less fertile; (3) water may carry to a soil phosphorus, potassium, and nitrogen, therefore increasing its total plant-food; and (4) water may carry to and deposit in a soil alkalis which in time may render it barren. The magnitude of these changes will be determined by the nature of the soil, the composition of the irrigation water, and the intelligence with which each is handled. Therefore, it is interesting and practical to consider briefly such changes as irrigation water may produce on a soil.

Ammonification.-Water is a universal solvent, as is exemplified by the fact that pure water is a chemical curiosity found only in the laboratory where it is obtained with great difficulty and maintained in a state of purity with great care. It is well known that when water becomes charged with carbon dioxid and other acids its solvent powers are greatly increased. It is less well known that the quantity and quality of these solvents which reach a water are governed by the classes and speed with which the bacteria act in the media with which water comes in contact. For bacteria transform the inert atmospheric nitrogen into organic and inorganic compounds. They change the plant residues into ammonia, nitrous, nitric, sulfuric, butyric, carbonic, and many other acids. Bacteria are widely distributed in soil, but like other plants they require water in their metabolism. The speed with which they break down plant débris and transform the nitrogen 
into ammonia depends upon the moisture in the soil medium. The average of numerous results obtained were as follows:

\begin{tabular}{c|c|c|c}
\hline $\begin{array}{c}\text { Per cent Water- } \\
\text { holding Capacity }\end{array}$ & $\begin{array}{c}\text { Per cent Am- } \\
\text { monia Produced }\end{array}$ & $\begin{array}{c}\text { Per cent Water- } \\
\text { holding Capacity }\end{array}$ & $\begin{array}{c}\text { Per cent Am- } \\
\text { monia Produced }\end{array}$ \\
\hline 10 & 2 & 60 & 100 \\
20 & 8 & 70 & 78 \\
30 & 32 & 80 & 57 \\
40 & 68 & 90 & 49 \\
50 & 85 & 100 & 45 \\
\hline
\end{tabular}

The soil which contains water to the extent of 60 per cent of its water-holding capacity produces more ammonia than does soil having any other water content. It has been our experience with all soils tested that this is the case irrespective of the physical nature of the soil. In other words, soils as unlike as clay and sand are at their optimum condition for ammonification when they contain 60 per cent of water.

Nitrification.-But how about the speed with which the ammonia is transformed into nitric acid? Is this dependent upon the water supply? This is answered by the following results:

\begin{tabular}{c|c|c|c}
\hline $\begin{array}{c}\text { Per cent Water- } \\
\text { holding Capacity }\end{array}$ & $\begin{array}{c}\text { Per cent Nitric } \\
\text { Acid Formed }\end{array}$ & $\begin{array}{c}\text { Per cent Water- } \\
\text { holding Capacity }\end{array}$ & $\begin{array}{c}\text { Per cent Nitric } \\
\text { Acid Formed }\end{array}$ \\
\hline \multirow{2}{*}{ Io } & II & 60 & 100 \\
20 & I7 & 70 & 40 \\
30 & 31 & 80 & 9 \\
40 & 62 & 90 & 0 \\
50 & 85 & & \\
\hline
\end{tabular}

Here also the greatest activity goes on in soil which is at 60 per cent of its water holding capacity. If the water content greatly exceeds this, the speed of the reaction is materially retarded. Moreover, an excessive quantity of water is more detrimental than is insufficient water. Under optimum conditions 
there may be produced from 50 to roo pounds of nitric acid in an acre-foot of soil during a season. This, when converted into a nitrate, becomes a valuable supply of food to the growing plant, and, as we have seen, the quantity produced is dependent upon the water applied. This quantity of acid would liberate appreciable quantities of phosphorus and potassium in the soil, which is therefore rendered available to the growing plant.

Other Acids. - The production of other acids by bacteria is dependent upon optimum moisture content, and they obey the same laws. It is found that the quantity of carbonic acid produced in twenty-four hours in a good aërable soil supplied with the optimum amount of moisture is enormous. Some results indicated that this at times may be as much as sixty-seven pounds per acre. The resulting carbonated waters react with some tricalcium phosphate of the soil with the formation of more readily soluble acid phosphates. Moreover, tricalcium phosphate is four times as soluble in water charged with carbonic acid as it is in pure water. This means that sixty-seven pounds of carbon dioxid is capable of transforming 236 pounds of tricalcium phosphate into 280 pounds of the soluble diacid phosphate, provided all of the carbon dioxid is utilized for this purpose. Although the greater part of the carbonic acid would be used in other ways, yet this shows the tremendous potential solvent powers of bacteria.

Potassium occurs in soil mainly as silicates and is rendered soluble by the nitrous, nitric sulfuric, acetic, lactic, butyric, and carbonic acids generated by the bacteria. Carbon dioxid will even react with the insoluble potassium silicates of the soil, liberating the potassium as the soluble potassium carbonate.

Salts Carried from Soil by Water.-Where only sufficient water is added to a soil to moisten or even saturate it and none drains from the soil, the plant-foot remains in the soil to be utilized by the growing plant. But when more water is added than the soil can hold, it passes through the soil and carries with it the fertility. The magnitude of this factor is exemplified by the enormous quantities of the various salts found in the waters of some lakes and oceans. 
It is estimated that the rivers of North America carry to the ocean each year $474,000,000$ tons of soluble constituents, a quantity sufficient to cover one hundred acres to a depth of nearly three thousand feet. Although the greater part of this is common salt and other non-valuable compounds, yet there are appreciable quantities of plant-food in such waters, as is witnessed by the 33.4 pounds of potassium, the 22.8 pounds of nitrogen, and the 3.5 pounds of phosphorus which work at the Utah Experiment Station has found to be the average quantity contained in one acre-foot of the streams of the intermountain region. Drain waters are even richer than this, and as much as 133.0 pounds per acre-foot of water have been found in some cases.

Loss of Nitrogen.-Carefully controlled experiments extending over half a century have been conducted at the Rothamsted Experimental Station where the yearly rainfall is about thirty inches, and the annual loss of nitrogen was found to be 35.5 pounds per acre. This is about the luss which experiments covering a period of ten years indicate occur at the Greenville (Logan, Utah) Experimental Farm, where twenty-five inches and over of irrigation water is applied to a soil during a season. The quantity actually leached from the soil is greater with large than with small but oftener applications of irrigation water. Moreover, the plants growing on the soil modify materially the loss of nitrates in the drain water.

The economic value of this is seen from the fact that this quantity of nitrogen in the form of commercial fertilizers, at twenty-five cents a pound for the nitrogen, would cost $\$ 8.88$. Moreover, grain grown on soil from which the available nitrogen is being continually leached is low in protein. Undoubtedly, the great merits of our dry-farm wheats as bread-makers in a large measure is due to the fact that the scanty rainfall during the growing season is not sufficient to remove the soluble nitrogen from the roots of the growing plants. Hence, it is taken up by the growing plants with the result that the gluten content of the wheat is high. In irrigated districts there is a great tendency to over-irrigate, hence low-protein grain is produced. 
Plant-food Carried to a Soil by Irrigation Water.-The Valley of the Nile has become famous in irrigation history not because it was among the first irrigated districts of the world but because of its extremely fertile fields, the fertility of which has been maintained throughout the ages. Other soils just as fertile to begin with have become barren. Why the difference? The Valley of the Nile owes its lasting fertility to the flood waters which carry to it rich deposits of silt each year. Hence, we find that a soil's fertility may increase and not decrease due to the water applied to it.

Moderate quantities of irrigation water can be applied to a soil without leaching from it soluble plant food. This water, as it evaporates deposits within the soil the soluble and insoluble plant food which it had carried to the soil.

Now, let us examine some of the results which have been obtained during the last few years at the Utah Experiment Station in a study of the irrigation waters of the intermountain region, bearing in mind that the constituents which are most usually lacking in soils are potassium, phosphorus, and nitrogen.

Hundreds of samples of water representing fifty-eight streams, the majority of which are extensively used for irrigation purposes, have been analyzed. These waters vary in potassium content from 49 parts per million to only .79 part per million. Slightly over one-half of the waters contained 5 parts per million. The importance of these results becomes more obvious when we examine the pounds of potassium carried to an acre of soil by twoacre-feet of water. This varies from 266.6 pounds in the case of the highest to 4.4 pounds in the case of the lowest with an average potassium content of 33.4 pounds per acre.

These results are not without economic significance, for the potassium in the highest would be sufficient to produce 370 bushels of corn, 230 bushels of wheat, or 34 tons of sugar-beets. The average for the streams is sufficient to produce 47 bushels of corn, 29 bushels of wheat, or 4 tons of sugar-beets.

Many of the soils of the intermountain region are rich in potassium; hence, this element is not as important as is phosphorus, 
which, although used by the crop in smaller quantities, is nevertheless at times the limiting factor in crop production.

The total phosphorus of the irrigation waters analyzed varied from traces to 5.47 parts per million. The great majority of them, however, contained less than one part per million. The average in two acre-feet of the stream was 3.46 pounds, for the wells $3.3^{6}$ pounds, and for the drains 1.82 pounds.

The phosphorus in two acre-feet of the water from the richest stream is sufficient for the production of 175 bushels of corn, I 20 bushels of wheat, or 33 tons of sugar-beets. In the case of all the other streams, whereas not as high, it undoubtedly plays a part in maintaining the phosphorus content of the soil. The bringing of these quantities of potassium and phosphorus to a soil must of necessity increase bacterial activity.

Even more important than the phosphorus is the nitrogen of the waters, for nitrogen is the limiting factor of crop production in most of the soils of the intermountain region. This varies from traces up to 24.3 parts per million. The average quantity of nitrogen in two acre-feet of the irrigation water is 22.8 pounds, while that in the highest is 132.2 pounds per acre. This would be sufficient to produce 186 bushels of corn, I I 4 bushels of wheat, or I 7 tons of sugarbeets.

Nitrogen Fixation.-Moreover, most of the soils of arid and semi-arid America contain a rich nitrogen-fixing flora. This is composed of both aerobic and anaerobic azofiers. Work already done indicates that these may increase the soil nitrogen twenty to thirty pounds an acre yearly. The quantity fixed, however, depends among other things, upon the water in the soil.

\begin{tabular}{c|c|c|c}
\hline $\begin{array}{c}\text { Per cent of Water- } \\
\text { holding Capacty }\end{array}$ & $\begin{array}{c}\text { Nitrogen Gain } \\
\text { Per Cent }\end{array}$ & $\begin{array}{c}\text { Per cent of Water- } \\
\text { holding Capacity }\end{array}$ & $\begin{array}{c}\text { Vitrogen Gain } \\
\text { Per Cent }\end{array}$ \\
\hline \multirow{2}{*}{10} & 30 & 60 & 75 \\
20 & 25 & 70 & 100 \\
30 & 25 & 80 & 90 \\
40 & 38 & 90 & 45 \\
50 & 45 & 100 & 25 \\
\hline
\end{tabular}


Maximum nitrogen fixation occurs when the soil contains between 60 and 70 per cent of its water-holding capacity, and when the soil becomes filled with water the actual gain is only onefourth what it is when the optimum moisture content is maintained.

These results probably help to explain the remarkable fertility of many of the irrigated soils of the arid regions. Some of them have been producing crops undiminished in quantity for upward of fifty years, and there is no reason why a limited few soils on which the richer irrigation waters are being used cannot continue for another fifty or one hundred years to produce maximum crops.

Alkali of Water-In addition to potassium, nitrogen, and phosphorus irrigation water carries varying quantities of alkalies which may at times be concentrated enough to become a menace when the water is used for irrigation purposes. For instance, of the fifty-eight streams examined, the majority of which were extensively used for irrigation purposes, thirteen of them carried alkali, which is dangerous if interpreted in the light of Hilgard's criterion that irrigation water should not contain over forty grains per million (57 I.2 parts per million).

The total soluble-salt content of these fifty-eight streams varied from 60 parts per million to I 3 I 2 parts per million. Moreover, it was found that a stream may be comparatively free from alkali during part of the year, but at other times it may be heavily charged with alkali. The melting of snow in the mountainous region usually has the effect of freshening the water, but local rains of ten have the opposite effect. In addition, drainage water, especially from alkali soils, greatly increases the alkaline content of the stream.

The magnitude of the problem which confronts the users of these waters and the speed with which they may yield barren soils is made clear by two examples. For instance, one stream carried sufficient salts in it that one acre-foot would deposit on the soil $3,58 \mathrm{r}$ pounds of soluble salts, or twenty such irrigations would reach the enormous sum of 71,600 pounds-sufficient, if allowed 


\section{6 \\ BACTERIA AND SOIL FERTILITY}

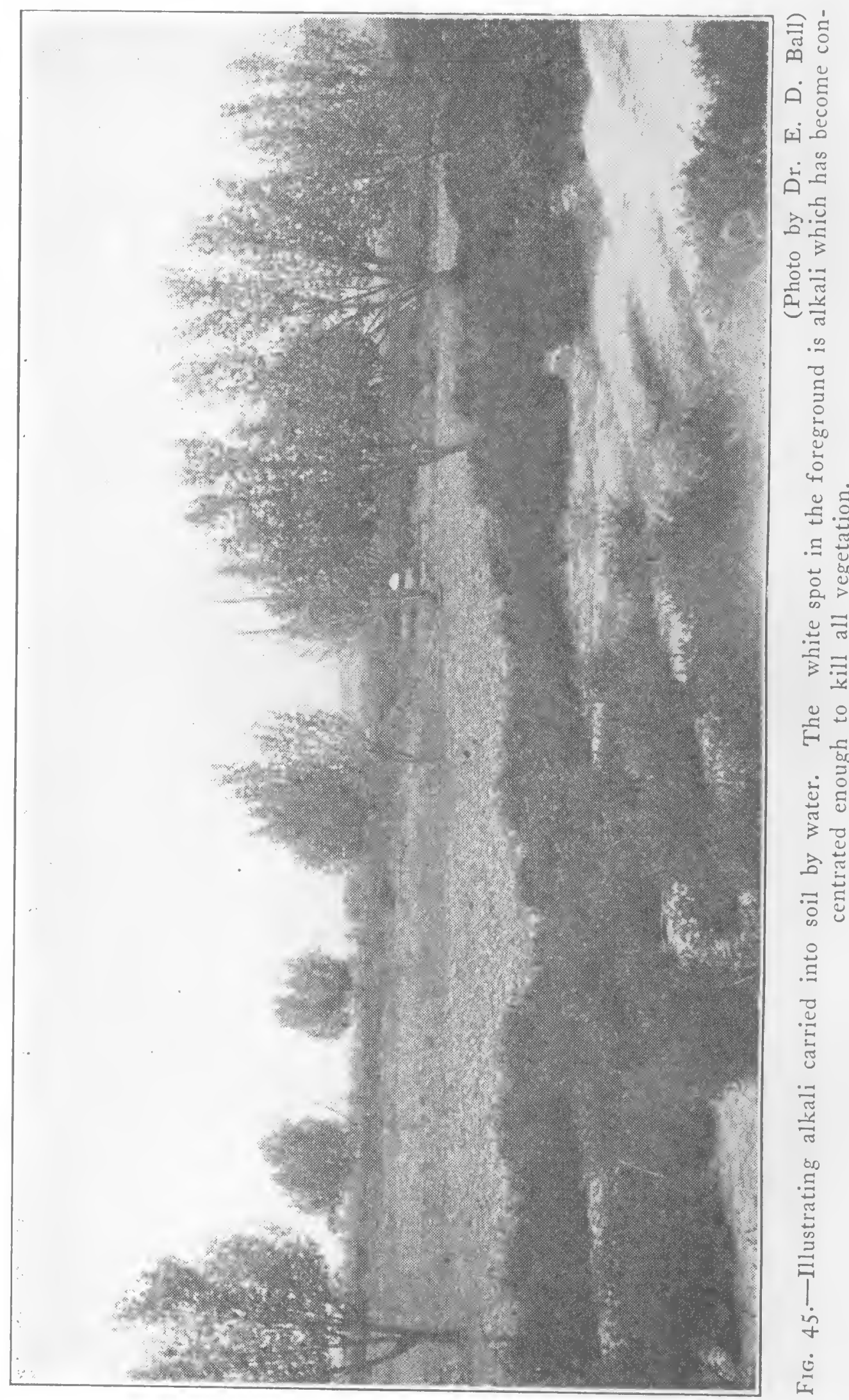


to accumulate, to render the soil barren. Another stream would carry to the soil in the same time and under the same conditions over fifteen tons of salt.

One application of such water may not kill plants, but what would a number of applications do? Moreover, one application may be sufficient to materially decrease nitrification in such a soil. This would then be reflected by decreased yields.

It is, therefore, evident that the intelligent use of irrigation water is a complex problem which requires a knowledge of the chemical, physical, and biological properties of the soil, together with a knowledge of the composition of the water and its influence upon the chemical, physical, and biological changes going on in the soil. One user of irrigation water may make of it a tool for making the desert bloom like the rose, whereas another user may through its use transform the most productive fields into a barren waste. 



\section{INDEX}

A

Acids, production of in soil, 22 I

Aeration, influence on ammonification, II 5

Aeration, influence on denitrifcation, 134

Aerobes, 59

Alfalfa, influence of, on nitrification, 128

Alfalfa, influence of, on soil fertility, I 78-I 80

Alinit, I 4 I

Alkali, influence of, on bacteria, 93, I 90-1 99

Alkali, influence of, on microörganisms, I 9 I-I 95

Alkali, in irrigation water, 225, 227

Alkali, kinds of, I9I

Alkali, removal of, from soil, r 98-1 99

Alkali, salts neutralization, I 97

Alkali, soil, I9I

Alkali, stimulation of bacteria by, I 92, 193

Alkali, toxicity of, I94, I 95

Alkali, antagonism amongst, I95196

Alkali, variation in toxicity in, I 95

Ammonification, I8, II 3

Ammonification, importance of process, II 7
Ammonification, influence of aeration, I I 5

Ammonification, influence of alkalies on, I 92, I 93

Ammonification, influence of arsenic on, 206

Ammonification, influence of manure on, 215, 216

Ammonification, influence of moisture on, I I 5, 21 9, 220

Ammonification, influence of reactions on, II 5

Ammonification, organisms causing, I I 3

Ammonification, speed of, II 4

Ammonifiers, 96

Ammonifiers, food requirements, II 5

Anaerobes, 59

Animals, relation of bacteria to, I $5,16,17$

Animalcules, I

Antagonism, I44, I 95, I 96

Antiseptics, influence on soil, 202, 203

Antibiosis, 6I

Arsenic, influence on ammonification, 206

Arsenic, influence on bacteria, 208, 209

Arsenic, influence on nitrification. 207

Arsenic, influence on nitrogen fixation, 207 
Arsenic, occurrence in soil, 206 Aristotlc, 3

Ash, requirements of bacteria, 59 Atmosphere in soil formation, $7^{6}$ Autotrophic bactcria, 56

Azotobacter chroococcum, I 48 Azotobacter, condition of growth, I 43

Azotobacter, discovery of, I4I Azotobacter, energy requirements of, 144, 145

Azotobacter, food requirements of, 144

Azotobacter, how fixes nitrogen, I 47

Azotobacter, influence of arsenic on, 209

Azotobacter, influence of calcium carbonate on, 142, 143

Azotobacter, influence of cellulose on, 189

Azotobacter, influence of lime on. I 44

Azotobacter, influence of nitrates on, 144

Azotobacter, morphology of, 148 Azotobacter, nitrogen fixed by, I 5 I-1 55

Azotobacter, occurrence of, I 42 Azotobacter, pigment production of, 148

Azotobacter, relation to nitrogen fixation, I 70

Azotobacter, soil inoculation with, I 49, I 50

Azotobacter, variation with depth, 142,143

Azotobacter, vinelandii, I 48
Azofication, defined, 140

\section{B}

Bacillus, 23

Bacillus, denitrificicans, 133

Bacillus, Ellenbachensis, I4I

Bacillus, mycoides, II 3

Bacillus, prodigiosus, 50

Bacillus, pyocyaneus, 50

Bacillus, radicicola, 158

Bacillus, subtilis, I I 3

Bacteria, antiquity of, $\mathrm{I}$

Bacteria, are plants, 13

Bacteria, on animals, I 5, I6, I7

Bacteria, ash requirements, 59

Bacteria as scavangers, $2 \mathrm{I}$

Bacteria, as soil formers, I 8, 19, 20, 78

Bacteria, autotrophic, 56

Bacteria, carbon requirements, 57

Bacteria, chemistry of, 42-52

Bacteria, classification of, 36-4I

Bacteria, definition of, 14

Bacteria, discovery of, I

Bacteria, food requirements, 546I

Bacteria, heterotrophic, 56

Bacteria, how studied, 42

Bacteria, importance of, 97

Bacteria, in dairy industry, 21

Bacteria, in milk, 15

Bacteria, in plants, 16

Bacteria, in soil, 14

Bacteria, in water, I4, 15

Bacteria, influence of cold on, 64

Bacteria, influence of electricity on, 67 
Bacteria, influence of heat upon, 200, 201, 202

Bacteria, influence of light on, 66

Bacteria, influence of . osmotic pressure on, 67

Bacteria, influence of poisons in soil, 202-209

Bacteria, influence of poisons on, 69

Bacteria, influence of pressurc on, 68

Bacteria, influence of shaking on, 67

Bacteria, influence of temperature on, 62

Bacteria, longevity of, 33

Bacteria, movement of, 2, 28-30

Bacteria, nitrogen requirements, 58

Bacteria, number of in soil, 92

Bacteria, occurrence of, $\mathrm{x} 4^{-1} 7$

Bacteria, oxygen requirements, 59

Bacteria, parasitic, 56

Bacteria, reproduction of, 25-27

Bacteria, role in nature, $12-22$

Bacteria, saprophytic, 56

Bacteria, shape of, 23

Bacteria, size of, 27,28

Bacteria, stimulation by alkali, 192

Bacteria, variation in shape, 24

Bacteria, vitamin requirements of, 59

Bacteria, water requirements of, 56

Bacteria, weight of, 27,28

Bacterial composition, 46

Bacteriology, history of, I-I I
Bacteriods, I 58

Boussingault, IO, I 20

Beans, how inoculated, 168

Beijernick, IO, I4I, I 58

Biological, agencies in soil formation, 91

Botulinus, toxin, 48

Bryophytes, I 4

Buonanni, 3 nitrogen fixation, 142,143

Calcium carbonate of soil, 80

Calcium carbonate, requirements of plants, 88

Capitate, 33

Capsule, 3 I

Carbon, assimilated by nitrifiers, I 26

Carbon bisulfid, influence on soil, 202, 203

Carbon cycle, 98

Carbon dioxid, in atmosphere, 98, 99

Carbon dioxid, sources of to plants, 156

Carbon, in man, 98

Carbon, nitrogen ratio, I I I

Carbon, requirements of bacteria, 57

Carbohydrates, influence on bacteria, I 49

Cardan, 3

Caron, I4I, I48

Cell, composition of, 46

Cell, structure, 30, $3 \mathrm{I}$

Cellulose, description of, 182 , I 83 
Cellulose, fermentation, I 82-1 89

Cellulose, ferments discovery of, I 85 -I 86

Cellulose, fermentation early work on, I 84,185

Cellulose, fermentation, function of, $187-189$

Cellulose, fermentation, products of, 186,187

Cellulose, function of in soil, I $83, I 84$

Cellulose, in soil, I83, I 84

Chemotaxis, 70

Chemistry of bacteria, 42-52

Chloroform, influence on bacteria, I 20

Classification, of bacteria, 36-4I

Classification, difficulties of, 37

Classification, methods of, 36

Classification, Megula's, 38

Classification, nomenclature of, 37

Classification, S. A. B'S, 39-4I

Clostridium, 33

Clostridium, pasteurianium, I 4 I

Cocci, 23

Cold, influence on bacteria, 64

Cold, influence on soil bacteria, 93

Color of soil, influence on temperature, I09

Copper, in soil, 206

Conn, 6

Corn, influence on nitrification, I 28

Cotton plugs, use of, 6

Crooks, William, 99

Crop, influence on nitrification, I 27
Crop, influence on nitrogen fixation, 146

Cultivation of bacteria, 42

Cycle of elements, 97-106

Cycle of elements, importance of bacteria in, 97

\section{$\mathrm{D}$}

Decay, i Io

Denitrification, I 32-I 37

Denitrification, bacteria causing, 96, I O I

Denitrification, bacteria in soil, I 33

Denitrification, defined, I 32

Denitrification, factors influencing, 135,136

Denitrification, function of, 136

Denitrification, loss of nitrogen due to, $\times 35$

Diphtheria, toxin, 47

Disinfectant, 69

Dusch, 6

\section{$E$}

Earth's crust, composition of, 90 Electricity, effect on bacteria, 67 Elements, required by plants, I 71,172

Emulsions, disinfecting powers of, 69

Energy, source of to azotobacter, I 44, I 45

Enzymes, 49

\section{$\mathrm{F}$}

Fallow, influence on nitrification, I 27,128 
Feed, how bacteria, 53

Feeds, composition of, 210

Fermentation early work on, 6

Fertility, influence of bacteria on, 200,202

Fertility, influence of legumes on, I 7 I-I 81

Fertilizers, influence on nitrogen fixation, 162

Flagella, 30

Food, function of, 54

Food, kinds of, for bacteria, 55

Food, quantity required, 54

Food, requirements of ammonifiers, II 5

Food, requirements of bacteria, 53-6I

Formaldehyde, as disinfectant, 69

Frank, 164

Fumigation, 69

Fungi, 14

\section{G}

Gelatin plate, first used, 7

Germicide, 69

Green manure, 217

Greenville soil, composition of, 90

Growth, factors influencing, 6270

Gunpowder, early use of, II 8

\section{$\mathrm{H}$}

Heat, influence on bacteria, 65

Heat, influence on soil fertility, 200-202

Heat, produced by bacteria, $5 \mathrm{I}$

Helmont, 3, 6, 156
Hellriegel and Wilforth, I40, 157,162

Heterotrophic bacteria, 56

Hiltner and Stormer's Theory, 203-205

Hopkins, 130

Humogen, I 50

Humus, 108

Humus, from various sources, I I 2

Hydrocyanic acid, 70

\section{I}

Ice, in soil formation, 75

Inoculation of soil, 165-170

Involution forms of bacteria, 24, 25

Iron, requirements of plants, 89

Iron, in soil, 82

\section{$\mathrm{K}$}

Kellerman and McBeth, $\mathrm{I} 86$

Koch, 7

Krainski, I 52

Kuhlmann and Dumas, I 19

Kuhne, I $2 \mathrm{I}$

\section{L}

Lead, in soil, 206

Leeuwenhoek, I

Legumes, conditions favoring, 160

Legumes, elements added by, I22, 173

Legumes, feed on nitrates, 177 , 178

Legumes, influence of non-legumes on, 162,163 
Legumes, influence on soil fertility, I $7 \mathrm{I}-\mathrm{I} 8 \mathrm{I}$

Legumes, inoculation of, $165-170$

Legumes, nitrogen fixed by, 163I 65

Legumes, nitrogen in, 176-I 77

Legumes, sources of nitrogen for, I $57,175,176$

Liebig, 6, 8, 156

Life, origin of, 3

Light, influence on bacteria, 66

Light, produced by bacteria, $5 \mathrm{I}$

Lime, as a disinfectant, 70

Lime, influence on nitrogen fixation, 142,143

Lipman, II 4, I23, I28, I53, I $55,162,168$

Löhnis, I 55

Losses in manure, 21 2, 213

M
Magnesium, requirements of
plants, 89
Manure, 210-2 I 8
Manure, composition, 210, 21 I
Manure, green, 217
Manure, influence on ammonifica-
tion, 215, 216
Manure, influence on bacteria,
215

Manure, influence on nitrification, 216,217

Manure, influence on nitrogen fixation, I 45, I6I, I62

Manure, losses of, 21 2, 213

Manure, losses of nitrates from, I 33, I 34, I 35
Manure, speed ammonified, II 4 Manure, value of, 213-215

Metabiosis, 60

Mesophilic-bacteria, 63, 64

Micron, 27

Microörganisms, 95

Microörganisms, shape and structure, 23-35

Milk, bacteria in, 15

Moisture, influence on ammonification, II 5

Moisture, influence on denitrification, 136

Moisture, influence of nitrification, 125

Molds, definition of, 14

Molds, morphology of, 35

Molds, nitrogen fixed by, I4I142

Movement of bacteria, 28-30

$\mathrm{N}$

Needham, 4

Nephi soil, composition of, 90

Nitrate, beds in Peru, 8

Nitrate, ferments isolated, 9

Nitrate, losses of, I 29, I 33, I 34

Nitrate losses, influence of water on, I 3 I

Nitrates, influence on azotobacter, I 44

Nitrates, quantity produced in soil, I 27

Nitrates, used by legumes, 177 , I 78

Nitrates, variation with depth, 124

Nitrification, I9, II 8 -I 3 I 
Nitrification, causes of, 120

Nitrification, early ideas on, II 9

Nitrification, carly work on, 8, 9, II 8

Nitrification, factors influencing, 123

Nitrification, in soil, $178-180$

Nitrification, influence of alkalies on, 192

Nitrification, influence of arsenic on, 207

Nitrification, influence of crops on, $127,128,178-180$

Nitrification, influence of fallow on, 127,128

Nitrification, influence of manure on, 216,217

Nitrification, influence of moisture on, 125,220

Nitrification, influence of oxygen on, 124

Nitrification, influence of temperature on, I 25

Nitrifiers, distribution of, 122

Nitrifiers, food requirements of, I 26

Nitrobacter, 122

Nitrogen cycle, 99-102

Nitrogen famine predicted, 99

Nitrogen fixation, early ideas on, 156

Nitrogen fixation, early work on, IO

Nitrogen fixation, early knowledge of, r 39-142

Nitrogen fixation, later work on, $156-159$
Nitrogen fixation, factors influencing, $143,160,161$

Nitrogen fixation, influence of alkalies on, 192

Nitrogen fixation, influence of arsenic on, 207

Nitrogen fixation, influence of cellulose on, 187

Nitrogen fixation, influence of crops on, 146

Nitrogen fixation, influence of fertilizer on, 162

Nitrogen fixation, influence of heat on, 201

Nitrogen fixation, influence of irrigation water on, 220

Nitrogen fixation, influence of lime on, 142,143

Nitrogen fixation, influence of manure on, 145

Nitrogen fixation, influence of moisture on, $16 \mathrm{I}, 162$

Nitrogen fixation, influence of nodules on, 160, 161

Nitrogen fixation, influence of non-legumes on, 162,163

Nitrogen fixation methods, 147

Nitrogen fixation, non-symbiotic, I 38 -I 55, I 56, I 70

Nitrogen fixed by bacteria, 20

Nitrogen fixed by legumes, 163165

Nitrogen fixed in nodules, 158 , I $59,160,161$

Nitrogen fixed in Utah soils, 146

Nitrogen fixed, quantity, I 39

Nitrogen fixers, discovered, I40, I $4 \mathrm{I}$ 
Nitrogen-fixing bacteria, 96

Nitrogen, forms of, 100

Nitrogen, how brought to soil, 138

Nitrogen, how maintained in soil, I 80, I $8 \mathrm{I}^{\circ}$

Nitrogen, in atmosphere, 100

Nitrogen, in feeds, 210

Nitrogen, in irrigation water, 223

Nitrogen, in legumes, 176, I77

Nitrogen, in manure, 2 I I

Nitrogen in Utah soil, I73

Nitrogen liberated in war, IOI

Nitrogen losses from manure, 212

Nitrogen losses due to irrigation water, 222

Nitrogen losses, early ideas of, 132,133

Nitrogen obtained from atmosphere, 175,176

Nitrogen, organisms fixing, I4I, 142

Nitrogen, requirements of bacteria, 58

Nitrogen, requirements of plants, 87

Nitrogen, soil gains in, 149, I 5 II 55

Nitrogen, synthetic, 139

Nitrogen, transformations of in soil, 132

Nitrogen, value of, 173, 174

Nitrosococcus, I 22

Nomenclature, 37

Nucleus, 3 I

\section{$\mathrm{O}$}

Oats, influence on nitrification, I 28
Organic matter, changed by bacteria, 107-1 I 7

Organic matter, composition, I09

Organic matter, function in soil, 108

Organic matter, influence on soil temperature, I09

Organic matter, influence on soil water, 109

Organic matter, kinds in soil, 108 Organic matter, origin of in soil, 108

Organic matter, quantity in soil, 107

Organic matter, value in soil, ro7108

Osmotic pressure, 67

Oxygen, influence on nitrification, 124

Oxygen, influence on nitrogen fixation, I6o

Oxygen, influence on denitrification, 136

Oxygen, requirements of bacteria, 59

\section{$\mathrm{P}$}

Pasteur, 6, 7, 98

Parasitic bacteria, 56

Pathogenic bacteria, 56

Peat "bacterized," 150

Pettenkoffer, 98

Phosphorus cycle, 102-106

Phosphorus in feeds, 210

Phosphorus in manure, 2 II

Phosphorus in soil, 80

Phosphorus in Utah soil, I 73

Phosphorus in water, 223 
Phosphorus losses from manure, 212

Phosphorus requirements of plants, 88

Pigments, bacterial, 50

Plant food, in water, 222

Plant requirements, 87, I 7 I, 172

Plants, bacteria in, 16

Plants, classes of, I 3

Plants, mutual relation of, 60

Plants, stimulated by antiseptics, 203,204

Plaster, I 92, I 93

Plasmolysis, 68

Poisons, influence on bacteria, 69, 200-209

Potassium, in feeds, 2 ro

Potassium, in manure, 2 I I

Potassium, in soil, 82

Potassium, in Utah soil, I 73

Potassium, in water, 223

Potassium requirements of plants, 88

Potatoes, influence on nitrification, 128

Pressure, influence on bacteria, 68

Priestley, 156

Protozoan theory, 205

Protista, 13

Pteridophytes, I 3

Ptomaines, 48

\section{$\mathrm{R}$}

Reaction, in ammonification, I I 5

Redi, 3

Reproduction, 25, 26, 27

Residual Soils, 83

Rotation, I 74, I75
Rothamsted Experiments, I 35

with manure, 2 I 3

rotation, 174,175

soil gain in nitrogen, 153

Röntgen rays, 67

Russell and Hutchin's Theory, 205

\section{S}

Salts, carried by water, 220, 225

Schlöesing and Mutz, 9, I 20

Schönbein, I I 9

Schroeder, 6

Schülze, 6

Shaking, effect on bacteria, 67

Size of bacteria, 27, 28

Soil alkali, influence on bacteria, I 90- I 99

Soil, bacteria in, I 4

Soil bacteria, factors influencing, 92

Soil bacteria, number in soil, 91

Soil bacteria variation with depth, 94

Soil bacteriology, development of, I - I I

Soil bacteriology, early history of, 8-I I

Soil, cellulose in, I 83, I 84

Soil classes, 83

Soil, durability of, 90, 173

Soil fertility, influence of cellulose on, I 87, 1 88, 1 89

Soil fertility, influence of legumes on, I 7 I-I 8 I

Soil fertility, how maintained, I 80-I $8 \mathrm{I}$

Soil formation, 7 I -82 


\section{8}

Soil formation, Biological agencies, 78

Soil formation, Chemical agencies, 76

atmosphere, 76

water, 77

Soil formation, Physical agencies,

72

ice, 75

temperature, 72

volcanoes, 75

water waves, 75,74

wind, 73

Soil formers, bacteria as, 18,19 , 20

Soil gain in nitrogen, I49, $15 \mathrm{I}$, I 55, 163-165

Soil, influence of carbohydrates on, I 49

Soil inoculation, 148-15I, 165I 70

Soil inoculation, factors governing, 150

Soil, loss of nitrogen from, I34, 135

Soil, organic matter in, I07

Soil, organic matter, function, 109

Soil reclaiming, I 97-1 99

Soil, residual, 83

Soil structure, 85

Soil structure, influence of organic matter on, IIO

Soil texture, 84

Soil, transported, 84

Spallanzani, 4

Spermatophytes, I3

Spirilla, 23

Spontaneous generation, 3
INDEX

Spore formation, 32, 33

Stains, first used on bacteria, 7

Sterilization, 66

Sterilization, early attempts, 4, 5

Sulfur as a disinfectant, 69

Sulfur cycle, 102

Sulfur in soil, $8 \mathrm{I}$

Sulfur requirements of plants, 89

Symbiosis, 60

Symbiotic bacteria, IOI

Symbiotic, non-, bacteria, IOI

\section{$\mathrm{T}$}

Temperature in soil formation, 72

Temperature influence on bacteria, 62

Temperature, maximum, 62, 63, 64

Temperature, minimum, 62, 63, 64

Temperature, optimum, 62, 63, 64

Temperature, of soil, I09

Texture, of soils, 84

Thallophytes, I 4

Thermal death point, 65

Thermophilic bacteria, 63, 64

Toxicity of alkali salts, 194, I 95

Toxicity of alkali salts, variation, 195

Toxins, 47

Transported soils, 84

Tubercles on legumes, 158,159 , I60

Tyndall, 7

U

Utah soil, composition, I 73 
Utah soil, gain in nitrogen, I 53 , 154

\section{$\mathrm{V}$}

Value of manure, 213

Vitamins, 59

Volcanoes, 75

Voltaire, 4

\section{W}

Walcott, I

Water, alkali content of, 225, 226

Water, bacteria in, I 4

Water, influence on acid production, 220, 221

Water, influence on ammonification, 219,220

Water, influence of denitrification, 136

Water, influence of nitrogen fixation, 224, 225

Water, injurious action on soil, 225

Water, in soil formation, 74
Water, loss of nitrogen, due to, 222

Water, plant food in, 223

Water, quantity in bacteria, 45

Water, requirements of bacteria, 56

Water, requirements in nitrogen fixation, 161,162

Waves, in soil formation, 75

Weigart, 7

Weight of bacteria, 27, 28

Wigand, I 58

Wind in soil formation, 73

Wilson, 162

Winogradski, 9, I 2 I

Woronin, I 58 $\mathrm{X}$

$X$-ray on bacteria, 67

\section{$\mathrm{Y}$}

Yeast defined, 14

Yeast morphology, 34

Yeast, nitrogen fixed by, I4I 


\section{LITERATURE OF THE CHEMICAL INDUSTRIES}

On our shelves is the most complete stock of technical, industrial, engineering and scientific books in the United States. The technical literature of every trade is well represented, as is also the literature relating to the various sciences, including books useful for reference as well as those fitted for students' use as textbooks.

A large number of these we publish and for an ever increasing number we are the sole agents.

ALL INQUIRIES MADE OF US ARE CHEERFULLY AND CAREFULLY ANSWERED AND COMPLETE CATALOGS AS WELL AS SPECIAL LISTS SENT FREE ON REQUEST

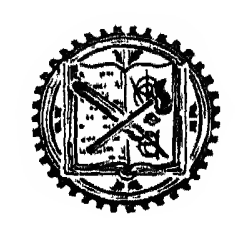

D. VAN NOSTRAND COMPANY Publishers and Booksellers 
